The Non-Technical Side Of Office Technology

Huub J.M. Ruël

2001

Ph.D. thesis

University of Twente

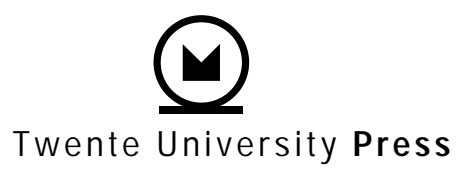

Also available in print:

http://www.tup.utwente.nl/uk/catalogue/management/office-technology/ 
The Non-Technical Side Of Office Technology 


\section{Samenstelling promotiecommissie}

$\begin{array}{lll}\text { Voorzitter: } & \text { Prof. dr. W. van Rossum } & \text { Universiteit Twente } \\ \text { Secretaris: } & \text { Prof. dr. W. van Rossum } & \text { Universiteit Twente } \\ \text { Promotoren: } & \text { Prof. dr. J.C. Looise } & \text { Universiteit Twente T\&M } \\ & \text { Prof. dr. ir. O.A.M. Fisscher } & \text { Universiteit Twente T\&M } \\ \text { Ass. promotor: } & \text { Dr. ir. J. de Leede } & \text { Universiteit Twente T\&M } \\ \text { Referent: } & \text { Dr. ir. C. van Slooten } & \text { Universiteit Twente T\&M } \\ & & \\ \text { Leden: } & \text { Prof. dr. D.R. Muntslag } & \text { Universiteit Twente T\&M } \\ & \text { Prof. dr. ir. R.J. Wieringa } & \text { Universiteit Twente INF } \\ & \text { Prof. dr. J.H.T.H. Andriessen } & \text { Technische Universiteit Delft } \\ & \text { Prof. dr. M.T.H. Meeus } & \text { Universiteit Utrecht }\end{array}$

(4)

Twente University Press

Publisher:Twente University Press, P.0. Box 217, 7500 AE Enschede, the Netherlands, www.tup.utwente.nl

English correction: Giles Stacey

Cover design: Jo Molenaar BNo

Print: Grafisch Centrum Twente, Enschede

(C) H.J.M. Ruël, Enschede, 2001

No part of this work may be reproduced by print, photocopy or any other means without the permission in writing from the publisher. 


\title{
THE NON-TECHNICAL SIDE OF OFFICE TECHNOLOGY
}

\author{
MANAGING THE CLARITY OF SPIRIT AND \\ THE APPROPRIATION OF OFFICE TECHNOLOGY
}

\section{PROEFSCHRIFT}

\begin{abstract}
ter verkrijging van
de graad van doctor aan de Universiteit Twente, op gezag van de rector magnificus, prof.dr. F.A. van Vught, volgens besluit van het College voor Promoties in het openbaar te verdedigen op vrijdag 21 september 2001 te 13.15 uur
\end{abstract}

door

Hubertus Johannes Maria Ruël geboren op 15 oktober 1968 te Lattrop 
Dit proefschrift is goedgekeurd door de promotoren

prof.dr. J.C. Looise

prof.dr.ir. O.A.M. Fisscher

de assistent-promotor

dr.ir. J. de Leede

en de referent

dr.ir. C. van Slooten 


\section{Table of contents}

Voorwoord/Preface $\quad 5$

Chapter One Introduction 9

1.1 A first orientation 9

1.2 Defining the office, office technology, and office technology projects 11

1.3 Office technology projects: difficult to manage 14

$\begin{array}{ll}\text { 1.3.1 Project failure or abandonment } & 15\end{array}$

1.3.2 Reasons for office technology project failure or abandonment 16

$\begin{array}{ll}1.4 \text { Starting point and central question } & 17\end{array}$

1.4.1 The central research question 18

1.5 Further outline of the thesis 19

$\begin{array}{ll}\text { Chapter Two Theoretical framework } & 21\end{array}$

2.1 Theoretical views on office technology in organizations 21

2.2 Structuration theory $\quad 23$

2.3 Adaptive structuration theory 24

2.3.1 The basics of adaptive structuration theory 26

2.4 The spirit of office technology 28

2.5 Office technology appropriation $\quad 30$

2.5.1 Appropriation in adaptive structuration theory 31

2.6 The context of office technology projects 32

2.6.1 Characteristics of the office technology development method 32

2.7 Towards a research model 37

Chapter Three Research method 45

3.1 From our research model towards methodology 45

3.1.1 Our methodological choices $\quad 47$

3.1.2 Multi-method research $\quad 47$

$\begin{array}{ll}3.2 \text { The case study design } & 49\end{array}$

3.2.1 The case study method $\quad 49$

3.2.2 Case selection $\quad 50$

3.2.3 Case study techniques $\quad 51$

3.3 Instrument development and operationalization of variables 52

3.3.1 The conversational interviews $\quad 52$

3.3.2 The non-conversational interviews $\quad 56$

$\begin{array}{ll}3.4 \text { The case report } & 61\end{array}$ 
4.1 Introduction

4.2 The organizational context 63

4.3 The project "Verdi" $\quad 64$

4.3.1 Methodology 64

4.3.2 Project characteristics $\quad 64$

4.3.3 User involvement 68

$\begin{array}{ll}\text { 4.3.4 Clarity of the spirit } & 69\end{array}$

4.3.5 Appropriation of the DIS $\quad 71$

4.3.6 The context of DIS appropriation $\quad 74$

$\begin{array}{ll}\text { 4.3.7 Project outcomes } & 75\end{array}$

4.4 Testing the hypotheses $\quad 77$

$\begin{array}{ll}\text { 4.4.1 Hypothesis } 1 & 78\end{array}$

$\begin{array}{ll}\text { 4.4.2 Hypothesis } 2 & 78\end{array}$

4.4.3 Hypothesis $3 \quad 79$

4.5 Summary of findings $\quad 81$

Chapter Five A callcenter agent support system project 83

5.1 Introduction 83

5.2 The organizational context 83

5.3 The project "Loan line 2.0" 84

5.3.1 Methodology 84

5.3.2 Project characteristics $\quad 84$

5.3.3 User involvement $\quad 88$

5.3.4 Clarity of the spirit $\quad 89$

5.3.5 Appropriation of the Loan Line 2.0 90

5.3.6 The context of appropriation of Loan Line 2.0 93

5.3.7 Project outcomes 94

5.4 Testing the hypotheses $\quad 95$

5.4.1 Hypothesis $1 \quad 95$

5.4.2 Hypothesis $2 \quad 96$

5.4.3 Hypothesis $3 \quad 97$

$\begin{array}{ll}5.5 \text { Summary of findings } & 99\end{array}$

Chapter Six A health insurance support system project 101

6.1 Introduction $\quad 101$

6.2 The organizational context 101

6.3 The project "Better" 102 
6.3.1 Methodology 102

6.3.2 Project characteristics $\quad 102$

6.3.3 User involvement 108

6.3.4 Clarity of the spirit $\quad 108$

6.3.5 Appropriation of Better 110

6.3.6 The context of appropriation of Better 113

6.3.7 Project outcomes $\quad 114$

6.4 Testing the hypotheses $\quad 115$

6.4.1 Hypothesis $1 \quad 115$

6.4.2 Hypothesis $2 \quad 115$

6.4.3 Hypothesis $3 \quad 117$

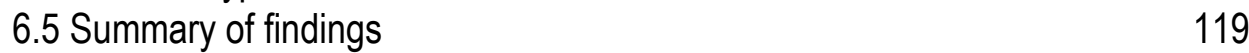

Chapter Seven An electronic calendaring system project 121

7.1 Introduction $\quad 121$

7.2 The organizational context 121

7.3 The project "Electronic calendar management" 122

$\begin{array}{ll}\text { 7.3.1 Methodology } & 122\end{array}$

7.3.2 Project characteristics $\quad 122$

7.3.3 User involvement $\quad 127$

7.3.4 Clarity of the spirit $\quad 127$

7.3.5 Appropriation of the electronic calendar 130

7.3.6 The context of appropriation of the electronic calendar 132

7.3.7 Project outcomes 133

7.4 Testing the hypotheses 134

7.4.1 Hypothesis 1

7.4.2 Hypothesis $2 \quad 135$

7.4.3 Hypothesis $3 \quad 137$

$\begin{array}{ll}7.5 \text { Summary of findings } & 138\end{array}$

Chapter Eight Cross case analysis $\quad 141$

8.1 Introduction 141

8.2 The office technology project characteristics 141

8.3 Comparing the outcomes of the hypotheses 147

8.4 The role of contextual factors 154

$\begin{array}{ll}8.5 \text { Summary of findings } & 165\end{array}$ 
9.1 Introduction

9.2 Discussing office technology project

9.2.1 From technology-driven towards technology use-centered

9.2.2 From a control-oriented spirit towards a support-oriented spirit

9.2.3 From neglected users towards responsible users

9.2.4 From neglecting organizational change towards preparing for unanticipated organizational change

9.2.5 From technical installion of office technology towards managing office technology appropriation

9.2.6 From improving the work process with new office technology towards improving the work process with human resources

References

Samenvatting/Summary 


\section{Voorwoord/Preface}

Op het moment dat ik dit schrijf, op een zwoele zomernacht rond een uur of twee, moet ik bekennen dat ik eigenlijk het gevoel heb niet te weten welke draai ik in hemelsnaam aan mijn voorwoord moet geven. Er gaat van alles door mijn hoofd, allerlei flitsen en flarden van gedachten en herinneringen schieten voorbij, maar geen enkele zet me echt aan om erop door te gaan. Toch moet er iets op papier, vind ik. Kom op Huub, laat je gaan. Oké, een laatste poging dan. Ik besluit nog eens terug te denken aan het artikeltje dat ik schreef voor het faculteitsblad, het T\&M nieuws, over het inzetten van genetisch gemodificeerde makke schapen op de moeilijk vervulbare plekken op de arbeidsmarkt. Al voor ik de herinnering helder voor de geest heb, merk ik dat ik enthousiast ben. $\mathrm{Er}$ begint zich een stroom van allerlei bizarre vragen te ontwikkelen in mijn hoofd. Zo vraag ik me af of het klonen van wetenschappers nu goed zou zijn voor de ontwikkeling (even los van wat dat precies inhoudt) in de wetenschap of niet? Maar het wordt nog gekker in mijn hoofd. Een andere vraag die opdoemt is of mijn eigen kloon een zelfde soort proefschrift zou schrijven als ik? Ik bedoel maar, als dit soort vragen opkomen is het tijd om te gaan slapen, denk ik. Nee, nog een vraag dringt zich op. Eentje die me bij het stellen ervan al in de lach laat schieten: hoe zou een kloon van mezelf reageren op mijn werk als hij in mijn promotiecommissie zou zitten? En met welke vraag zou hij komen op de openbare verdediging? Of stel dat ik zelf een lid zou zijn van de commissie van mijn kloon. Stop! ..... Twee uur 's nachts is duidelijk een te laat tijdstip om een voorwoord te schrijven. Ik sla een aantal vliegende beesten bij me weg die door het wijd openstaande raam van mijn studeerkamer naar binnen zijn gekomen, en ik besluit in de ochtend mijn poging tot het schrijven van een voorwoord te vervolgen op de volgende wijze:

Promoveren is een proces, en het afleveren van een product dat proefschrift heet is slechts een van de uitkomsten. Veel meer nog dan het proefschrift is vooral persoonlijke ontwikkeling een uitkomst van dat proces. Nu ik aan het eind van dat proces sta kan ik terugblikken en de balans opmaken. Ik kom dan tot de volgende conclusie. Het promotieproces heeft me veel gegeven. Het heeft mijn blik verruimd, mijn denkkracht gestimuleerd, (reis)kansen geboden om het bedrijf dat wetenschap heet te verkennen, en veel goede collega's, ja zelfs vrienden gegeven. Kortom: veel rozengeur en maneschijn. Er is natuurlijk een keerzijde. Het promotieproces is namelijk ook een worsteling, een intellectueel en psychologisch gevecht met jezelf maar ook met anderen. Er zijn dagen waarop enkel aaneengesloten wolkenvelden voorbij lijken te trekken. Echter, nu het proces ten einde is moet ik zeggen dat die wolkenvelden toch ook weer niet zo dik waren als ze leken. Ik beschouw het als een leerervaring. 
Er breekt nu een nieuwe fase aan voor mij. Dat zet me er toe aan enige woorden van dank te richten tot een aantal mensen die een belangrijke rol hebben gespeeld in de afgelopen jaren. Laat ik beginnen bij de mensen die een directe rol hebben gespeeld. Allereerst Jan Kees Looise. Ik dank hem voor het in mij gestelde vertrouwen in de afgelopen jaren. Hij gaf me de gelegenheid om mijn enthousiasme voor het AlO-schap zo'n vier, vijf jaar geleden om te kunnen zetten in het tastbare resultaat dat nu voor u ligt en een stuk persoonlijke ontwikkeling door te maken. Ik moet zeggen dat ik zelfs geen dag spijt heb gehad van mijn besluit om AlO te worden.

Olaf Fisscher dank ik eveneens voor zijn vertrouwen. Zijn 'down to earth'benadering van bedrijfskundig onderzoek hielp mij om de praktische relevantie niet uit het oog te verliezen. Bedankt!

Jan de Leede, ook erg bedankt. Je was een voorbeeld, een altijd aanwezige steun, en prima gids voor een beginnende onderzoeker. Kees van Slooten, bedankt voor je voortdurende steun, en je gerichte commentaar. De rust en stabiliteit die je uitstraalt zijn waardevol voor een wat rusteloos type zoals ik.

Verder bedank ik de overige leden van de promotiecommissie voor hun goedkeuring die ze hebben gegeven aan mijn proefschrift.

Ja, en dan heb ik nog een flink aantal HRM-collega's die ik wil bedanken voor hun indirecte rol die ze hebben gespeeld in het afronden van dit proefschrift. Een bont gezelschap eigenlijk, maar wel een erg fijn gezelschap. Ik noem ze liever niet allemaal met naam omdat ik dan een volgorde moet hanteren, en die zou mogelijk kunnen suggereren dat de eerstgenoemde een betere collega voor me was dan de laatstgenoemde (hoe diplomatiek!). Echter, vier collega's noem ik toch met naam. Allereerst mijn paranimfen Tanya en Andre. Tanya, bedankt voor de goedheid en kracht die je uitstraalt en tentoon spreidt. Je bent een bron van inspiratie..... Andre, bedankt voor je vriendschappelijke collegialiteit, je betrouwbaarheid, en altijd constructieve insteek.

Verder wil ik Beate noemen. Je hebt veel voor me betekend. Ik wil zuinig zijn op mijn herinneringen. Dan nog wil ik Maarten van Riemsdijk met naam noemen. Hij was een richtingaanwijzer op het moment dat het nodig was. Tot de andere HRM-ers zeg ik: hoe komt het toch dat ik me de afgelopen jaren zo op mijn plek heb gevoeld? Ik hoop dat dit na mijn promotie zo mag blijven.

Er is een flink aantal collega's binnen en buiten deze faculteit met wie ik de afgelopen jaren intensieve contacten heb onderhouden. Tegen hen zeg ik: iedereen die de bedoeling heeft gehad om een bijdrage te leveren aan mijn werk bedank ik voor de moeite. Het heeft ongetwijfeld een positieve invloed gehad. Nadrukkelijker genoemd moeten toch worden de collega's die deel uitmaken van het structuratie-genootschap, Edward Faber, Karen Fehse, Marike Hettinga, en Sander Rijnders. De gezamenlijke barbecue op zondag 19 augustus bij mij 'at 
the countryside' beschouw ik als een start voor een langjarige voorzetting van ons genootschap.

Tot slot is er natuurlijk mijn familie, mijn ouders en mijn vier zussen, die een plek verdienen in dit voorwoord. Ik besef dat het schrijven van een proefschrift de aandacht voor aardse zaken wel eens heeft verdreven. Ik hoop echter dat er de komende tijd weer een betere balans zal ontstaan. Bedankt voor jullie onvoorwaardelijke liefde, begrip, belangstelling, en steun.

Lattrop, augustus 2001 


\section{One}

\section{Introduction}

"Everything that can be invented has been invented." With these sweeping words, the Commissioner of the United States Office of Patents recommended in 1899 that his office be abolished, so spectacular had been the wave of innovation in the late $19^{\text {th }}$ century. History is littered with such foolish predictions about technology. The lesson is that any analysis of the economic consequences of the current burst of innovation in information technology (IT - computers, software, telecoms and the Internet) should proceed with care. At one end, the Internet's boosters have boldly proclaimed it as the greatest invention since the wheel, transforming the world so radically that the old economies textbooks need ripping up. At the other extreme, skeptics say that computers and the Internet are not remotely as important as steam power, the telegraph or electricity. In their view, IT stands for "insignificant toys", and when the technology bubble bursts, its economic benefit will turn out to be no greater than that of the $17^{\text {th }}$-century tulip bubble.

Source: the Economist, A survey of the new economy, September $23^{\text {rd }} 2000$

As the above citation argues, it is difficult to predict technological developments. One hundred years after the Commissioner of the US Office of Patents spoke his 'historic' words, we are in the comfortable position of being able to see how 'wrong' these words were. Unfortunately, we probably will not be in a position to see who was 'right or wrong' about the impact of IT in 2001 a hundred years from now. Unless that is people will be able to live for 150 years or longer due to developments in IT!

\subsection{A first orientation}

This thesis is about projects that aim to develop and implement information technology (IT) in office environments, in short, office technology projects. It is a report of a study carried out on office technology projects from a non-technical perspective. So, why this choice of office technology projects?

First of all, office work plays an important role in Western economies, and the use of information technology in this type of work seems inextricably 
connected to it. People employed in office environments are confronted with an almost continuous introduction of new office technologies, as decision-makers in companies believe that the market drives them towards being very attentive to the latest developments in the field of IT. Of course, the role of IT has changed over the years, and it has become a strategic factor in doing business. The emergence of electronic commerce is an example of how IT has become a strategic factor. As a result, the number of projects in organizations to develop and implement new office technologies has unarguably increased. This trend makes office technology projects an interesting subject of study.

Moreover, applying IT in offices has an immediate impact on a company's non-silicon-based resources, its employees. Introducing a new piece of IT in an office environment usually implies change for the people working in this environment, for example changes in user interfaces, changes in job content, changes in the physical work environment, or changes in performance criteria. It is this immediate impact that makes office technology projects a subject of suitable concern for a thesis such as this, on the social aspects of business sciences.

Although this alone is in our opinion enough reason, we think it is also interesting to point to the large amounts of money being invested in IT. For example, in 1999, in the United States alone $\$ 243$ billion was invested on IT (Zaal, 2000). In the Netherlands, the private service sector invested Dfl 2,6 billion in 1997 in IT, and manufacturing industry Dfl 1,2 billion in 1998. The total amount of IT costs (new investments and maintenance) in 1998 were Dfl 19,6 billion (http://www.statline.cbs.nl). That this amount will probably not decrease in the next few years is shown by a recent study from Ernst \& Young. At least $60 \%$ of the organizations that participated in their survey (650 Dutch organizations) expect to invest more money than before in IT in the next few years (Ernst \& Young, 2001). These figures show that IT plays an important role in organizations, and for this reason IT development, implementation and use, deserve ongoing scientific attention.

In thesis we aim to contribute to a more profound understanding of office technology development, implementation and use. This is scientifically interesting and relevant since the outcomes of our study will say something about the value of the theoretical framework applied. It is also of practical interest, as the results of the study can be of help in the everyday practice of office technology projects.

Before we continue it is necessary to define more precisely what we mean by three main terms used in this thesis: the office, office technology, and office technology projects. We will clarify these terms in section 1.2 . 


\subsection{Defining the office, office technology and office technology projects}

Offices are the physical places where people carry out information processing functions. Hirschheim (1985) notes that many conclude that an office can be best considered within the context of what an office does, namely: receiving information, recording and storing information, structuring information, processing information, and providing access to information. Panko (1984) distinguishes two types of offices: procedural and non-procedural offices. Procedural offices are those in which the main functions involve carrying out sets of explicit steps towards a specified end. For example: accounting offices, insurance administration offices and income tax offices. Non-procedural offices are those that have to achieve more general missions or goals. There are no pre-specified explicit steps for achieving these. The most imaginative examples are top management offices, but professional offices also fit this type.

Regarding a definition of office technology we opt for Irving and Higgins' choice (1991), who define it as follows: "Office (information) technology is a seamless integration of telecommunication, data processing, and personal computing with manual business processes, which support key business functions...."(p.8). Irving and Higgins' full definition also contains the sub sentence: "...and which improves effectiveness, efficiency, and the quality of working life". To us, this does not seem relevant in defining office technology, as improving effectiveness, efficiency, and quality of working life is not a character of the technology itself. These are only expected or hoped for effects, hoped for to arise. When office technology is brought into use but does not lead to an improvement in business performance, in our opinion it is still office technology.

We use the term office technology, but in the literature a number of different terms are also used, for example: office automation systems, office information systems, and office applications. These are all used for effectively the same type of systems, and include software as well as hardware. Table 1.1 presents an overview of office technology systems, specific office applications, and the dominant functions fulfilled by office technologies. 


\begin{tabular}{|l|l|l|}
\hline \multicolumn{2}{|c|}{$\begin{array}{l}\text { Office technology } \\
\text { systems }\end{array}$} & $\begin{array}{l}\text { Specific applications } \\
\text { technology } \\
\text { fulfilled by the office } \\
\text { technom }\end{array}$ \\
\hline $\begin{array}{l}\text { Electronic editing } \\
\text { systems }\end{array}$ & $\begin{array}{l}\text { Text processing, Desktop } \\
\text { publishing, } \\
\text { Electronic copying }\end{array}$ & Text processing \\
\hline $\begin{array}{l}\text { Electronic } \\
\text { communication } \\
\text { systems }\end{array}$ & $\begin{array}{l}\text { Electronic mail, } \\
\text { Electronic spoken } \\
\text { messages, } \\
\text { Fax }\end{array}$ & Communication \\
\hline $\begin{array}{l}\text { Electronic meeting } \\
\text { systems }\end{array}$ & $\begin{array}{l}\text { Electronic meetings, } \\
\text { Collaboration support, } \\
\text { Teleconferencing, } \\
\text { Telework }\end{array}$ & $\begin{array}{l}\text { Communication, } \\
\text { manipulation and } \\
\text { analysis of } \\
\text { information }\end{array}$ \\
\hline $\begin{array}{l}\text { Electronic imagingl } \\
\text { Document } \\
\text { management systems }\end{array}$ & $\begin{array}{l}\text { Electronic document } \\
\text { management, } \\
\text { Image/video processing, } \\
\text { Presentation graphics, } \\
\text { Multimedia }\end{array}$ & $\begin{array}{l}\text { Information storage } \\
\text { and retrieval }\end{array}$ \\
\hline $\begin{array}{l}\text { Office management } \\
\text { systems }\end{array}$ & $\begin{array}{l}\text { Electronic office support, } \\
\text { Electronic calendar } \\
\text { management, } \\
\text { Task management, } \\
\text { Workflow management }\end{array}$ & $\begin{array}{l}\text { Administrative } \\
\text { support }\end{array}$ \\
\hline
\end{tabular}

Table 1.1 Overview of types of office technologies and their function (based on O'Brien, 1995)

In general, the development and implementation of new office technology in offices is managed through projects, in short, office technology projects. We define these as: an initiative to develop, implement and use a new office technology system carried out by a temporal organization especially brought into being for the realization of this initiative. Office technology projects imply that a temporal organization is formed. In general these are structured as follows: at the head of the project organization is a steering committee, which is responsible for the project as a whole. Under the authority of this steering committee, one or more project teams operate that actually carry out the project plan(s). The project team can initiate one or more task forces for specific parts of the project, 
under the authority of the project team 1 . Figure 1.1 shows how a project organization can be organized, based upon the dominant view of project management:

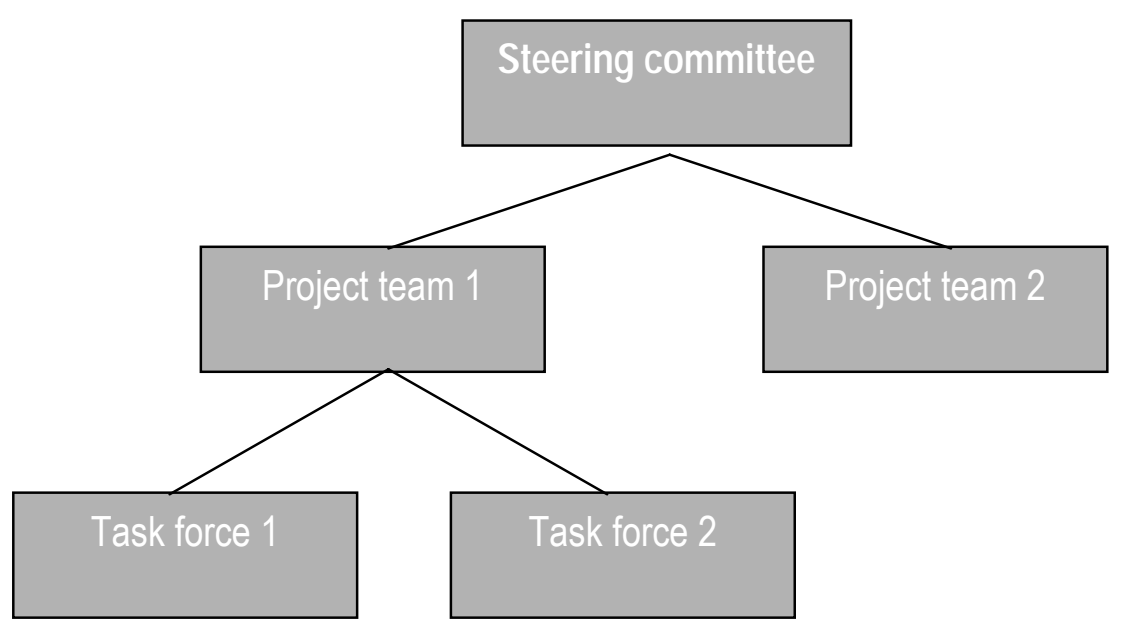

Figure 1.1 Example of a project structure

There are three domains of knowledge that have to 'collaborate' and to be integrated in office technology projects, as well as in IT projects in general: knowledge about IT/office technology, knowledge about the management of systems development and implementation, and knowledge about the organization of work. These three domains of knowledge have different representatives. IT experts/IT companies bring in knowledge about IT/office technology, project management brings in knowledge about the management of IT projects (development, implementation, organizational change), and employees/users bring in knowledge about the organization of work. Therefore, in general one can discern three parties in office technology projects ${ }^{2}$. Figure 1.2 shows this:

\footnotetext{
${ }^{1}$ We acknowledge that the way projects are structured depends upon the project management philosophy which is applied (implicitly or explicitly). The consequences of the project management philosophy applied in office technology projects is beyond the scope of this thesis, but is a topic which deserves more attention. Our impression is that the dominant line of thought in the project management literature starts with a quite structured/static view on projects.

${ }^{2}$ In the rest of this chapter we will proceed using both terms: office technology projects or, in short: IT projects. According to Applegate (1998), for the most part, the spending on IT is directed at modifying office work and improving productivity, and in most cases concerns what we define as office technology.
} 


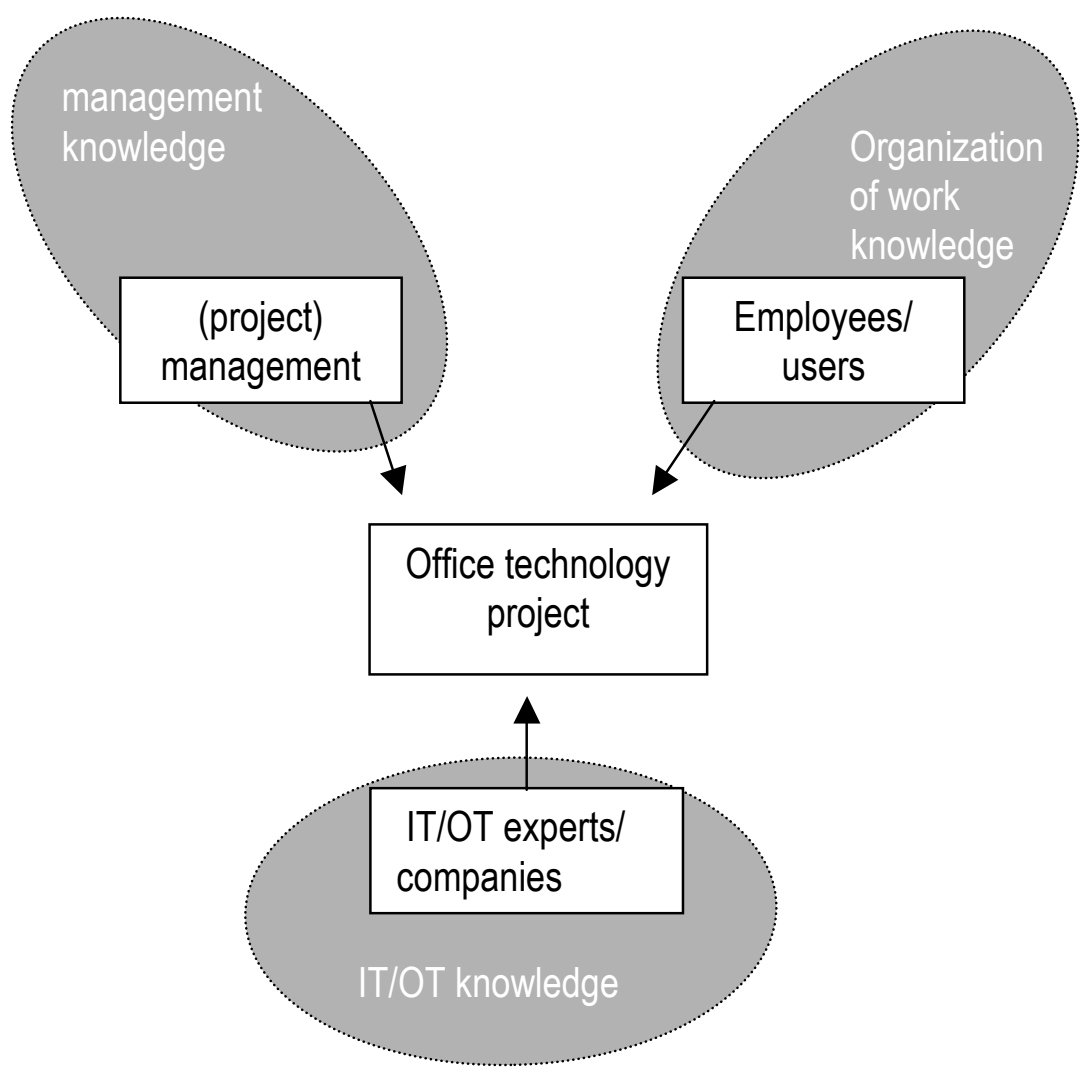

Figure 1.2 Parties in office technology projects

Having defined and explained what is meant by the three basic terms used in this thesis, we will elaborate on the thesis' topic in section 1.3.

\subsection{Office technology projects: difficult to manage}

Office technology projects are a familiar phenomenon in organizations. This is shown by the results of Ewusi-Mensah and Przasnyski's study (1994). In $27 \%$ of the organizations that responded to their survey, between 1 and 20 IT projects had taken place in the previous five years. In over $60 \%$ of the organizations that responded to the survey, more than 20 IT projects had taken place within the same period. It was estimated that the total budget for $71 \%$ of the projects was less than $\$ 2 \mathrm{~m}$ each. The duration of about $30 \%$ of the IT projects was between 1 and 6 months, 13\% lasted between 7 and 12 months, and $15 \%$ between 13 and 18 months (estimated durations). 15\% of the projects lasted more than 3 years. 
Siskens et al. (1989) studied the ability of IT projects to meet budget and time expectations. In general $63 \%$ of IT projects exceeded their budget by up to $50 \%$, and $7 \%$ exceeded their budget by more than $50 \%$. Large projects performed worse than small projects: $30 \%$ of larger projects exceeded their budget by more than $50 \%$. Regarding the duration of projects, Siskens et al. (1989) found that $70 \%$ of IT projects overrun by up to $50 \%$, and $10 \%$ overrun by more than $50 \%$. Again, if smaller and larger projects are distinguished the figures change: $31 \%$ of the larger projects overrun by more than $50 \%$ of their time allocation.

The introduction of IT is often exclusively based upon the belief that the intended advantages will occur; attempts to really measure the advantages are in many cases never undertaken (Fitzgerald, 1998). So, whether the expected advantages actually occur often remains questionable. This, despite the considerable impact that IT projects often have on the work environment of employees and the large amounts of money that are being invested in IT. However it has become clear that to quite an extent these investments do not achieve their objectives. A large number of office technology projects end in complete or partial failures (Doherty and King, 1998; Ewusi-Mensah and Przasnyski, 1994). However, hard evidence about the rate of project failures is not easy to find. Ewusi-Mensah and Przasnyski (1994) state that there are several studies that deal with information systems' failure from the usage and operations viewpoint after a system has been implemented, but that the abandonment of IT projects under development has not received much attention ${ }^{3}$. Ewusi-Mensah and Przasnyski ${ }^{4}$ collected data on IT projects from IT senior executives and system managers in Fortune 500 companies. Their results showed that approximately one third of the respondents indicated that five or more IT projects had been abandoned in their organizations within the period 1982-1986. This is supported by a classic Dutch study on automation projects, carried out by Riesewijk and Warmerdam (1988). This showed that almost half of the projects $(48,5 \%)$ ended 'problematically' or unsuccessfully 5 .

\footnotetext{
${ }^{3}$ Ewusi-Mensah and Przasnyski (1994) consider IT project abandonment as different from IT failure. By IT project abandonment they mean IT development processes that are ended before a system is implemented. By IT failure they mean the disfunctioning of IT after its full implementation. This disfunctioning can be caused by badly designed technology or failure in usage.

${ }^{4}$ Ewusi-Mensah and Przasnyski sent out more than 1400 questionnaires and received 82 completed usable responses (5.6\%). Ewusi-Mensah and Pzrasnyski suggest that one reason for this very low response rate might be that discussing IT project abandonment has negative connotations, and therefore is not a favoured topic (besides this, it was also suggested that the length of the questionnaire (11 pages) played a role). The useful responses where analysed and showed that approximately one third indicated that five or more IT projects had been abandoned in their organizations within the period 1982-1986.

${ }^{5}$ These are projects that were supported by external automation experts. The study of Riesewijk and Warmerdam (1988) concerned 274 companies. 233 of them had carried out an automation project in the last
} 
The figures as presented here suggest that IT projects in general are not a 'quick and easy fix'. Although these figures come from somewhat 'old' studies, there is no reason to believe that the situation has improved. One might argue that project management tools have improved and therefore IT projects in general are doing better nowadays. The other side of the coin is that IT has become more complex than 5 or 10 years ago, and that therefore it is likely that there is no improvement over 5 or 10 years ago. IT projects are shown to be, in a lot of cases, 'hard to manage'. This prompts us consider the reasons for the problems experienced in IT projects.

\subsubsection{Reasons for office technology project failure or abandonment}

In section 1.2 we pointed to the fact that in IT projects three parties have to collaborate. This multi-party element of office technology projects complicates the project process, which is widely recognized in practice as well as in the literature (see for example Hirschheim, 1985; Lyytinen and Hirschheim, 1987). However, we believe this is only one part of the problem. The underlying problem is broader.

Ewusi-Mensah and Przasnyski (1994) identified the following project management issues that 'contribute' to project abandonment or failure: staffing, managerial and communicational aspects of project management, and interaction between participants and their perception of work-related issues. In an earlier study, Ewusi-Mensah and Pzrasnyski (1991) found that organizational factors are an important cause of IT project abandonment (e.g. corporate management fails to deal with behavioral, political or organizational issues, or end-users contribute to project abandonment). Vadapalli and Mone (2000) state that human and management issues play a critical role in the ability of an organization to lead a technology project to success. Hornsby et al. (1992) provide the following reasons for IT underperformance:

- lack of guiding organizational and business strategies;

- lack of end-user participation and end-user 'ownership' of systems;

- lack of attention to education, training and awareness;

- lack of organizational resources and support (in terms of the 'soft' infrastructure);

- lack of attention to organizational issues such as organization design, organizational culture, and management style; and

- lack of attention to psychological issues such as the design of jobs, the allocation of systems tasks, and the usability of the system. 
Observing this, it seems clear that several authors provide reasons for project failure or abandonment that have to do with the fact that, in IT projects, management, users and IT professionals have to collaborate, and especially because they have different stakes in the process. But it is also clear that IT projects do not give adequate attention to organizational and human factors, which we consider to be a broader area than only the interaction between different parties. Organizational and human factors have to do with the organization of work and the probable changes that will occur as a result of the implementation of new IT, in our case particularly office technology.

Clegg et al. (1997) found that: "Regarding the impact of new information technology on the way in which work is organized and upon individual job design, the majority view (of the interviewees) was that this is hugely important but largely ignored in practice. Again this was seen as a topic that is significantly under-estimated. Where it is addressed this is because the job design implications of technical change are discovered, usually relatively late in the development process. These findings demonstrate that IT projects remain technology-led. IT is not seen in an integrated way as raising sets of related business and organizational issues." (pp. 859). Overall, these observations establish a belief that the lack of attention to the non-technical side is a major cause of IT project failure or abandonment.

\subsection{Starting point and central question}

Office technology projects are not a 'quick and easy fix'. They often fail to meet their objectives and, as we have noted, this is probably due to a lack of attention for the non-technical element in office technology projects. The question that emerges is: how can we contribute to improving this? In the literature several theories and approaches are available (which will be elaborated upon in chapter 2) that claim to provide clear answers. However, new insights are frequently required in order to improve our understanding of the nontechnical side of office technology projects. To develop this non-technical side, we introduce the concepts of spirit and appropriation. These concepts are adopted from Adaptive Structuration Theory (AST) as developed by DeSanctis and Poole (1994). AST starts from the assumption that the effects of advanced information technology are not a function of the technology itself, but of the way it is used. DeSanctis and Poole (1994) state that advanced information technology can be divided into a spirit and structural features. Spirit concerns the intention of a certain technology. The structural features concern the technical parts of an advanced information technology. Further, DeSanctis and Poole state that advanced information technology use must be considered as a matter of appropriation, in other words that technology is not an artifact from outside that determines user behavior, but that technology is 'realized' by the actual 
behavior of users. In theory, office technology 'carries' a certain spirit, which should guide users, but this spirit can only be materialized when users work with, or appropriate, the technology. A precondition is that users have to have a clear image of this spirit. Through being involved in the development and implementation process, it is possible for users to influence this spirit and to become aware of it.

The concepts of spirit and appropriation are especially adopted in this thesis to study office technology projects, as the concepts of spirit and appropriation in our view, can provide a basis to understand the non-technical aspects of office technology. The concepts presented here will be elaborated upon in chapter 2.

\subsubsection{The central research question}

The concepts introduced, spirit of office technology, and appropriation, are the essence of this thesis. These are considered as relevant in getting a better understanding of the non-technical side of office technology; and improving office technology development, implementation and use. Hence, the central research question becomes:

How can office technology projects be improved by the use of the concepts of the spirit of office technology and office technology appropriation?

In order to appropriately answer this question, it is divided into four subquestions.

1. How is the involvement of users in office technology projects related to the spirit of an office technology?

2. How is the spirit of office technologies related to the appropriation of office technologies by users?

3. How is the appropriation of office technologies related to work process effectiveness?

4. How do contextual factors influence the relationship between a certain spirit and office technology appropriation, and the relationship between office technology appropriation and work process effectiveness?

Having introduced this thesis' topic, and presented its central research question, we will now outline the content of the subsequent chapters. 


\subsection{Further outline of the thesis}

Following this first, introductory chapter the following chapter will develop the theoretical framework that will guide our study, resulting in a research model.

Chapter 3 will elaborate on the research method used, which is qualitative in nature, but also includes quantitative methods. Chapter 4, 5, 6, and 7 each report on office technology project. We apply the theoretical framework with the help of our research method, in order to answer the central research question. The research covers the following office technologies: a workflow management system combined with a document imaging system, a callcenter agents support system, an health insurance support system, and an electronic calendar management system.

Chapter 8 contains a cross-case analysis which creates an overview and directs us towards the conclusions that will answer our research question. These conclusions will be presented in chapter 9 and lead to theoretical and practical recommendations.

The outline described here is constructed schematically below in Figure 1.3. 


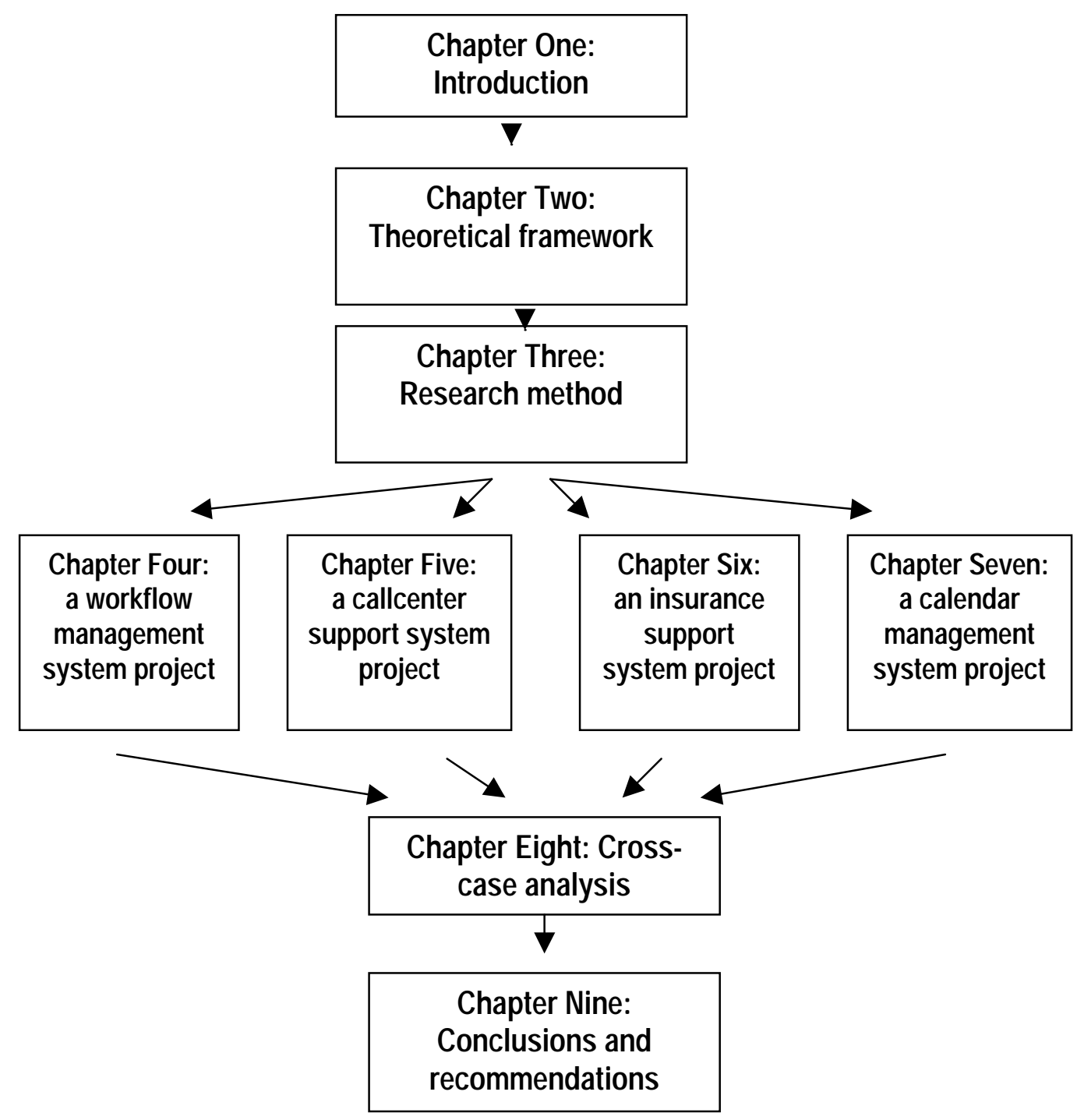

Figure 1.3 Thesis outline 


\section{Two}

\section{Theoretical framework}

This chapter presents the theoretical basis of the study. It is structured in the following way: firstly, we discuss the different views on office technology found in the literature. Secondly, adaptive structuration theory (AST) is discussed. Thirdly, based upon AST, a research model is developed and the central research question is developed in a more detailed way.

\subsection{Theoretical views on office technology in organizations}

The social sciences, and more specifically organizational sciences, deserve to be acknowledged for their discussion on the relationship between IT and organization, given the number of publications on this topic. If we look at the theoretical views adopted in research on office technology implementation in organizations, we can observe a complex picture. Generally the theories applied in this research root in organizational theory, which is a very colorful field. Good reviews of this have been presented by a several authors (e.g. Bolman and Deal, 1984; Morgan, 1986). Over the years, theories on office technology have developed in parallel with theoretical perspectives on organizations. Orlikowski (2000) notes the following organization theories that have been 'transmitted' to research on information technology: contingency theory, strategic choice models, Marxist studies, symbolic interactionist approaches, transaction-cost economics, network analyses, practice theories, structurational models, and innovation theories. All these approaches can be recognized in the current research on office technology in organizations. However, if we place the discussion on office technology in organizations in a time frame, we can discern periods in which certain lines of thinking dominate.

Until the mid '80s the discussion was characterized by two basic lines of thinking, technological determinism and technological voluntarism, which took turns in dominating this discussion. The second half of the 1980s gave birth to views that assume technology to be dualistic in nature, meaning that technology can be both enabling and constraining. Based upon sociological theory, especially Anthony Giddens' structuration theory, researchers in the field of IT and organizations, tried to 'adopt' a theoretical middle ground. One of the first researchers who applied structuration theory was Barley (1986). He developed a model of technology-triggered structural change, which posits that technology might 'facilitate' certain social dynamics that will lead to both anticipated and 
unanticipated structuring consequences (for example, decentralization or centralization). In Barley's view, technology is a social object. The context of use defines its meaning, but a specific technology's physical form and function remains fixed over time and the contexts of its use. Thus, technology, in Barley's view, is on the one hand a social construct, but on the other hand has a stable physical nature. He does not accept that technology can be modified physically during use (Orlikowski, 1991).

Orlikowski (1991) is of the opinion that well this might be true for certain technologies (such as CT scanners, which were object of Barley's study), but this is not the case for information technologies. She argues that: "While technologies may appear to have objective forms and functions at one point, these can and do vary by different users, by different contexts of use, and by the same users over time" (Orlikowski, 1991, p. 6).

At the start of the 1990s, Orlikowski (1991) and Orlikowski and Robey (1991) reconceptualized the relationship between information technology and organizations based upon Giddens' structuration theory (1984). Orlikowksi's approach pronounced that information technology in organizations should not be considered as a stable 'external' agent that impacts on organizational forms, nor as a subject of interpretation only. Information technology itself is an 'agent of change' depending on how it is used. The role of information technology is framed in terms of a mutual interaction between human agents and information technology. Information technology, in Orlikowski and Robey's view, provides certain 'structures' that are brought into action by human agents. These 'structures' can be altered by human agents during use.

Orlikowski's reconceptualization of the relationship between information technology and organizations is characteristic of an important line of thinking during the 1990s. It attempts to give new input to the discussion on this topic, by withdrawing from the 'traditional' deterministic and voluntaristic positions of the social sciences that had influenced the discussion to date (Orlikowski and Baroudi, 1991). Others that follow this approach include Poole and DeSanctis (1989, 1990), Walsham (1993) and DeSanctis and Poole (1994). The similarity between these authors' models is that the focus is on information technology use. Effects of information technology cannot be predicted beyond how it is used in a certain context. In other words, effects emerge as IT is used. It is especially the approach of DeSanctis and Poole (1994), adaptive structuration theory, which will be the main basis for our study. As this approach is inspired by Giddens' structuration theory this needs to be first understood. Hence, the next section will elaborate on structuration theory. Section 2.3 then discusses adaptive structuration theory. 


\subsection{Structuration theory}

One of the major issues in the social sciences, especially in sociology, is what is often called the 'structure vs. agency' debate. The essence of this debate is whether human behavior is determined by universal 'laws', or whether human behavior is voluntaristic in nature. A number of social theorists has challenged this division and proposed an integrated meta-theory that recognizes both the deterministic and the voluntaristic dimensions of social reality. One of these theorists is Anthony Giddens, a British social scientist who, since the 1970s, has tried to 'redefine' sociology. Giddens is not the first theorist who tried has entered this abovementioned debate in the social science. Touraine (1973), Berger and Luckmann (1966), Bourdieu (1977), Bhaskar (1975, 1979), and others, have all attempted to resolve the issue. Giddens developed a theoretical perspective, which he calls the theory of structuration (from now on: structuration theory) (Giddens, 1979, 1982, 1984).

Structuration theory assumes that social reality is constituted by both, the subjective perception of human actors and the more or less objective institutional properties. Giddens introduces the so-called duality of structures, by which he means that institutional properties of social systems are created by human action, and then serve to shape future human action. Therefore, on the one hand, human action can be considered to constitute the institutional properties of social systems, and on the other hand, can be considered to be constituted by institutional properties. From this it follows that social phenomena have to be explained by both the role of human action and the effects of existing institutional properties.

In terms of the structuration theory, structure is an abstract property of social systems. It is not something concrete, fixed in time and space, and neither is it tangible. Structure cannot exist without the human actors who enact and interpret its dimensions. Individuals call on the structures that were enacted in the past by prior human action (their own or that of others). In this way, human action is shaped by structural properties, which in turn recreate the structural properties anew. Giddens puts it simply: ....."Man actively shapes the world he lives in at the same time as it shapes him" (Giddens, 1982, p. 21). Structure in this way acknowledges both subjective and objective aspects.

The division between action and structure is only analytical. Both structure and action can be subdivided across three dimensions. From an institutional perspective, Giddens distinguishes structures of signification, structures of domination, and structures of legitimation. From the human action perspective, Giddens distinguishes communication, power, and moral sanction. On top of this, Giddens specifies three 'modalities' that link the 'realm' of action and the 'realm' of social structure: interpretive schemes, facilities, and norms. Interpretive 
schemes are standardized, shared stocks of knowledge that humans 'use' to interpret behavior and events, hence achieving meaningful interaction. Facilities are the means through which intentions are realized, goals are accomplished, and power is exercised. Norms are the rules governing sanctioned or appropriate conduct, and they define the legitimacy of interaction within a setting's moral order. The three modalities determine how the institutional properties of social systems mediate deliberate human action that constitutes social structure. These modalities link the realm of structure to the realm of action. This linkage is referred to as the process of structuration (Giddens, 1979). This is illustrated in Figure 2.1:
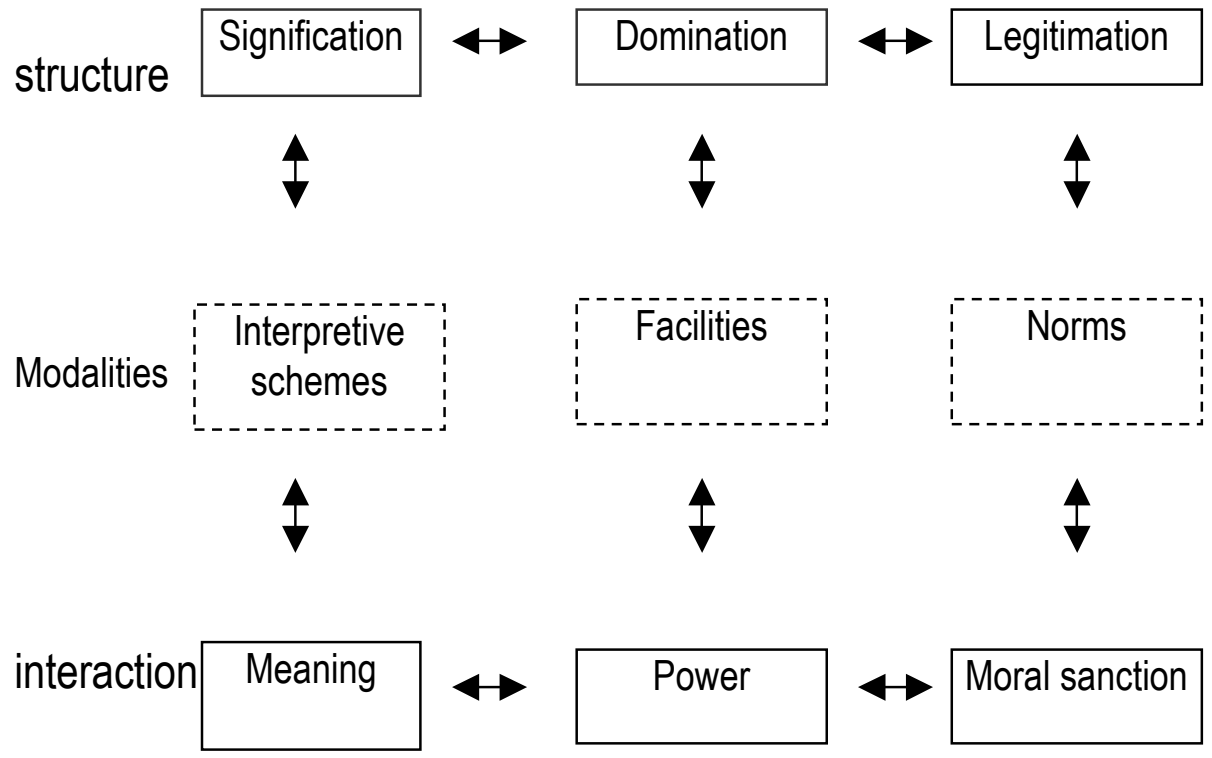

Figure 2.1 Structuration theory: the analytical dimensions of duality of structure (adopted from Giddens, 1984)

DeSanctis and Poole (1994) and Poole and DeSanctis (1989, 1990), were inspired by the basic ideas of structuration theory and developed an extended theory, initially to study groups using group decision support systems (GDSSs). In more recent publications the focus has been broadened towards advanced information technologies in general (DeSanctis and Poole, 1994). In the next section, DeSanctis and Poole's adaptive structuration theory will be explained in detail.

\subsection{Adaptive structuration theory}

In chapter 1 we argued that the main reason for office technology project failure is the lack of attention paid to the non-technical side of office technology 
development, implementation and use. This suggested the need for a study on office technology that was centered on its non-technical aspects. Adaptive structuration theory (or AST) seems of use in carrying out such a study, as it starts from the basic assumption that the effects of technology are not a function of the technology itself, but of the way it is used. Furthermore, adaptive structuration theory provides promising concepts which emphasize the nontechnical side of office technology in organizations (Ruël, 2001, forthcoming). Hence, AST will be considered in more detail in this section.

With AST, DeSanctis and Poole try to develop a theory that holds the 'middle ground', inspired by the work of Anthony Giddens they want to position themselves between technological determinism (or objectivism) and voluntarism (or subjectivism). In addition to Giddens, DeSanctis and Poole (1990) cite Heidegger and Ong as sources of inspiration, since they are representatives of an important school of thought which regards technologies as inherently 'social' in nature. Social processes create the right conditions for the evolution of technology. Society is considered as a matrix in which technologies and their applications are embedded. Technologies sustain and change society, which is seen as mutual determinism. In this context, DeSanctis and Poole refer to Heim who notes that "modern society and technologies are so bound together that it is impossible to sort out which causes which" (Poole and DeSanctis, 1990, p. 181).

Initially, AST was developed for studying groups which were using an electronic group decision support system. "It looks into the process of human usage of computer systems and at the nature of group-computer interaction", was the argument advanced by Poole and DeSanctis (1989, p. 150). The mid 1980s can be identified as the period in which such electronic group decision support technologies came to the fore. The development and application of these technologies was initially based on the premise that if effective information and interaction support were provided then, the quality of group outcomes would improve (Chin, et al., 1997). At the beginning of the 1990s the literature indicated a lack of consistency in the results of group decision support systems (GDSS) research. Some studies found performance improvements through using GDDSs, while others found no meaningful differences in performance. In general, these inconsistencies were explained by variations in study design, tasks, or instrumentation. Diversity in GDSS design across studies was also used to explain away the observed differences. Poole and DeSanctis (1990) put forward an alternative explanation: "Observed differences are attributable to the fact that various groups use the GDSSs differently" (p.176). This might now seem obvious, but when digging deeper it becomes apparent that the use of technologies, especially by groups, is a complicated matter that had received little attention before 1990. In order to get a clearer picture of GDSSs and their impact and to get a clearer view of the findings of GDSS research, one solution is to develop theories with "adequate pictures of individual and social technology 
usage" (Poole and DeSanctis, 1990, p.1976). Poole and DeSanctis were of the opinion that the concept of information technology should be reconsidered, and that structuration theory would assist them to achieve this and to formulate their adaptive structuration theory. Poole and DeSanctis state: "Building on the theories of structuration advanced by several European social theorists, the theory of adaptive structuration attempts to explain how technology affects group and organizational processes and resultant outcomes" (1989, p.149). Their adaptive structuration theory holds that it is the active use of technology by people that determines the observable outcomes, rather than the view that technology is a direct, causal, influence on human behavior. This is the approach we adopted in this study. Therefore, we begin with a closer look at the basics of AST.

\subsubsection{The basics of adaptive structuration theory}

As has already been noted, adaptive structuration theory initially in particular focused on group processes for the purpose of studying the use of group decision support systems. The reason for labeling it as 'adaptive' is that adaptation to the situation is seen as the primary goal of group action. This approach can accept differences in outcomes that occur even when the same conditions exist, since AST accepts that groups are not merely information processing entities but that they have a social existence that has to be considered when using group technologies (Chin, et al., 1997). DeSanctis and Poole (1994) developed a model that presents AST in its full context, as presented in Figure 2.1. The eight arrows in the model reflect seven hypotheses:

1. Advanced information technologies (AIT) provide structures (in terms of structuration theory) which can be described in terms of their spirit and features. Different sets of spirits and features lead to different forms of interaction with the technology.

2. Use of AIT structures can vary depending on other contingencies that offer alternative sources of structures.

$3 \& 4$. New sources of structure emerge as the technology and other sources of structure are applied during the course of interaction.

5. New structures emerge in group interactions as the spirit and features of an AIT are appropriated in a given context and then reproduced in group interactions over time.

6. Group decision processes will vary depending on the nature of AIT appropriation.

7. The nature of AIT appropriation will vary depending on the group internal system. 
8. Given AIT and other sources of structure (n1, n2, n3, etc.) ideal appropriation processes, and decision processes that fit the task at hand, then the desired outcomes of AIT use will result.

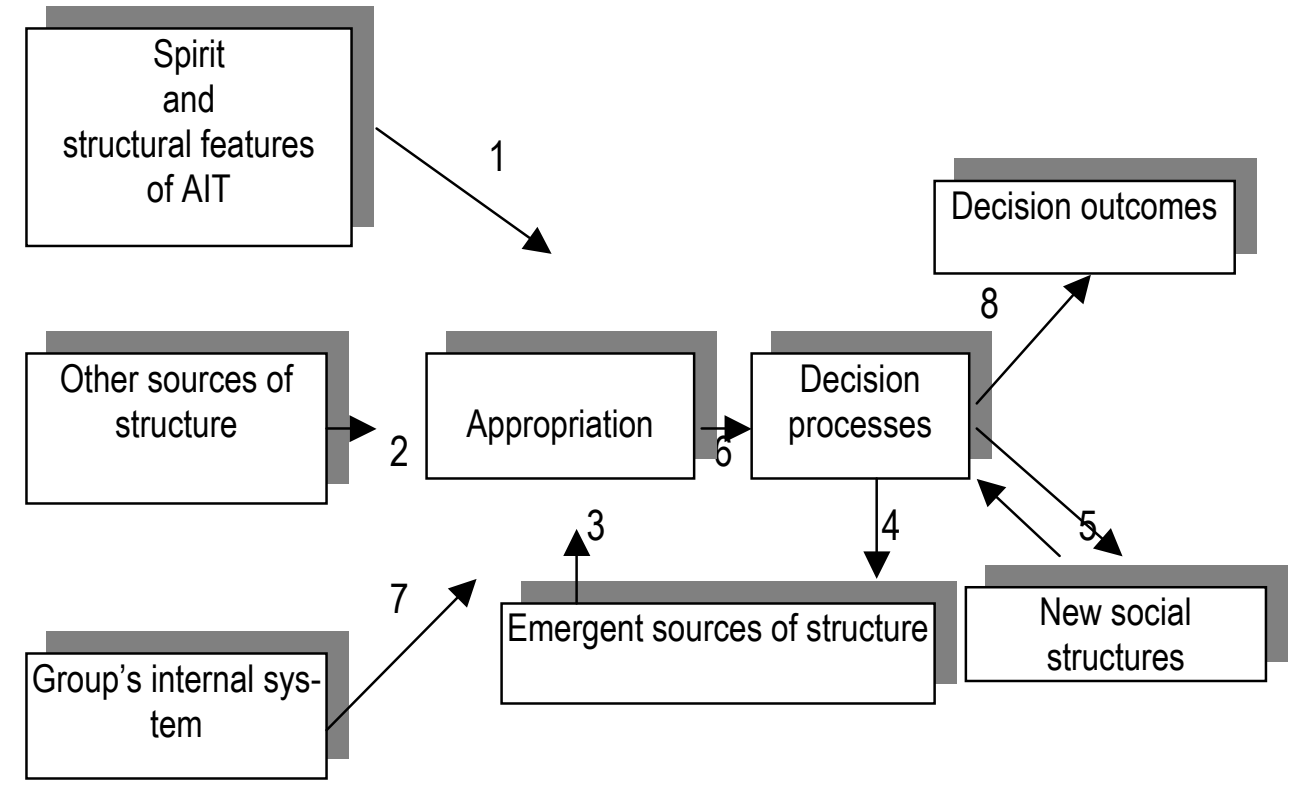

Figure 2.1 The original adaptive structuration theory model (DeSanctis and Poole, 1994)

Figure 2.1, and the seven hypotheses represent the original AST model. They are based upon two main ideas: firstly that advanced information technologies are social in nature. This is expressed by the concept of spirit. Secondly that advanced information technologies are being 'realized' by its use. This is expressed by the concept of appropriation.

Since AST was initially developed to study group decision support systems in use, the model and the hypotheses contain 'decision processes', 'decision outcomes', and 'group's internal system'. However, DeSanctis and Poole (1994) stress that AST is also useful for studying other advanced information technologies. We are especially interested in applying it to office technology projects, more specifically to office technology development, implementation, and use. Furthermore, AST can be considered as a general framework from which more specific hypotheses can be drawn. It is especially the concepts of spirit and appropriation, that we believe are promising (AST is a relatively young theory) and these have not been used before in studies on office technology projects. Applications of AST in studies on electronic group systems are also still scarce. Nevertheless, good examples of applying AST in studying 
electronic group system use do exist and include Poole and DeSanctis (1992), Wheeler et al. (1993), Chin et al. (1997), Kahai et al. (1997), and Majchrzak et al. (2000).

Applying AST to office technology gives our study an interesting challenge. In the following sections we elaborate on the spirit and the appropriation of office technology.

\subsection{The spirit of office technology}

One of the central elements of AST is the belief that advanced information technology is social in nature. Hence, the introduction of the concept of spirit. DeSanctis and Poole (1994) define spirit as follows: "Spirit is the general intent with regard to values and goals underlying a given set of structural features" ( $p$. 126). The concept of spirit concerns the 'official line' which the technology presents to people regarding how to act when using the system, how to interpret its features, and how to fill in gaps in procedure which are not explicitly specified (p.126). The spirit of a technology provides what Giddens calls 'legitimation' to the technology by supplying a normative frame with regard to behaviors that are appropriate in the context of the technology" (Desanctis and Poole, 1994, p.126). The spirit can also give 'signification' to users, as it helps them to understand and interpret the meaning of the IT. Finally, the spirit can be a means of 'domination', because it presents the type of influential moves to be used with the IT. Some users may be privileged by this and others constrained. Therefore, in terms of structuration theory, the concept of spirit concerns the total set of possible structures promoted that may be called upon by means of the structural features (later on in this section we will discuss how to define the structural features). The concept of spirit suits very well what Orlikowski (1991) calls the 'interpretive flexibility' of information technology. The implication of this assumption is that the realization of any object may differ between situations, and that the object itself can change as people change their mode of using it.

If we project this onto the type of IT included in our study, that is office technology, this can be clarified with the following example. A specific office technology may 'contain' the spirit: open organizational communication. If we analyze this spirit, using the three types of structures (based upon Giddens, 1984), it is then possible to say that the spirit provides users with structures of signification that appeal to interpretive schemes about organizational communication, and allow the meaning to arise that the technology aims to support open organizational communication. The spirit also provides structures of domination that facilitate users to send electronic messages to people higher in the organization's hierarchy (which might not have been allowed before the new office technology was implemented). Finally, the spirit of the new office technology provides structures of legitimation with the norm that people who use 
indecent words in their electronic messages are excluded from the use of the new office technology.

This example is visualized in Figure 2.2.

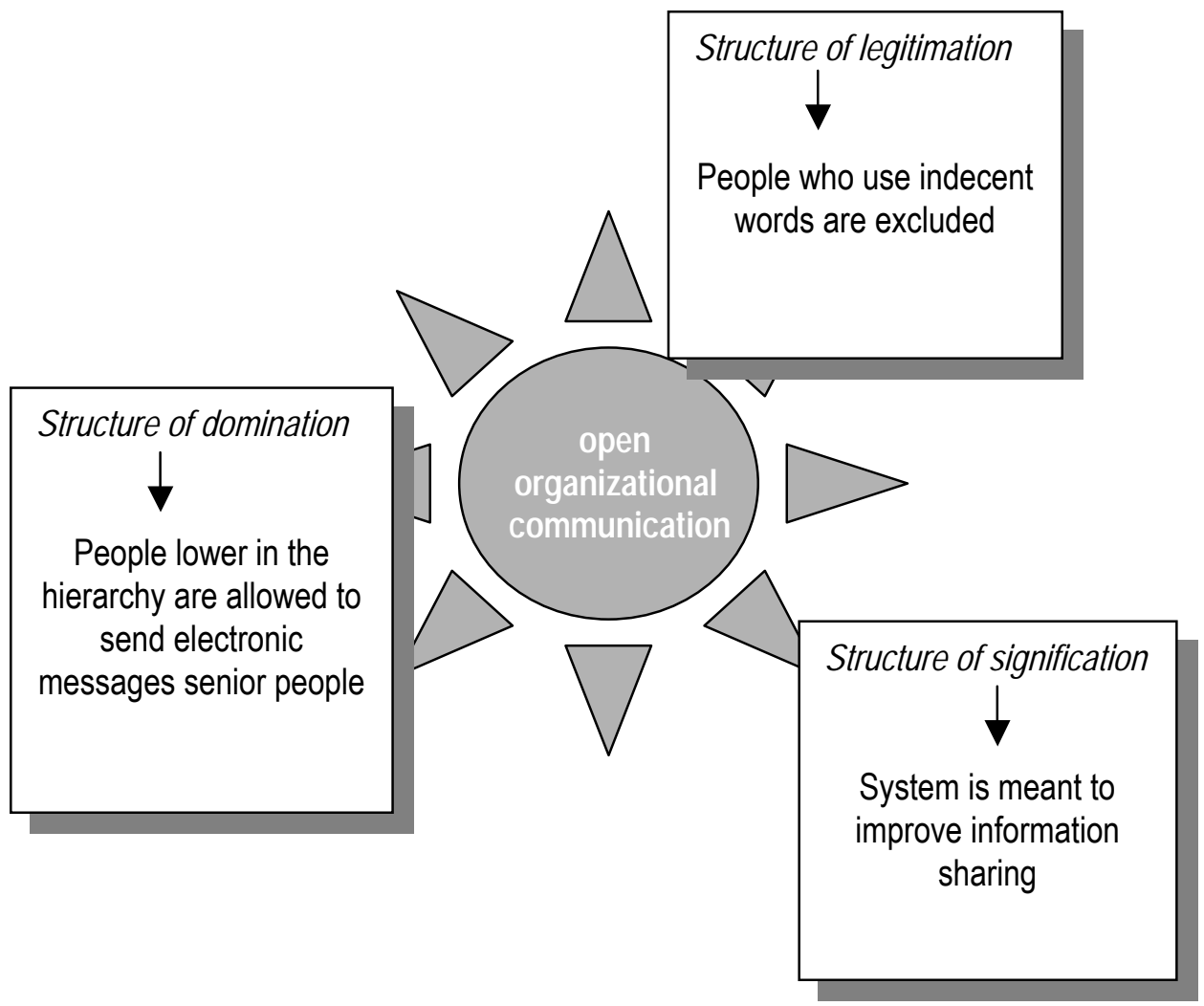

\section{Figure 2.2 An office technology's spirit 'deconstructed' into possible structures}

In terms of AST, structural features are the specific rules and resources, or capabilities, offered by the system. This suggests that an office technology must contain 'visible' structures but we do not agree with this point of view. In AST, the concepts of spirit and structural features are not clearly separated. Structural features only refer to the technical capabilities of a system. Structures never have a physical form, structures can only become 'visible' in human action. Information technology, in our perception, may consist of dozens of technical capabilities, but it is the technology's spirit that enables users to make sense out of these capabilities. Therefore we prefer to speak of technical features, rather than structural features.

In the context of information technology, it can be said that, when users work with a specific information technology means, they make a selection from the potential of structures 'offered' by the spirit, by means of the technical 
features. This implies that a technology's spirit can enable users to appropriate, but it also can constrain them.

Some information technologies present a clear consistent spirit, whereas others do not. If users apply information technology in contradictory ways, this might suggest that the technology does not present a coherent clear spirit. A clear coherent spirit would be expected to direct appropriation in more or less pre-defined ways, but an unclear, incoherent, spirit would have a less directive impact on user behavior (DeSanctis and Poole, 1994). This is where the concept of spirit can help in understanding why office technology implementation can end in unanticipated consequences, and even in complete failure; the less clear the spirit, the less users are likely to use the office technology in accordance with its spirit (Ruël, 2001). This may result in unanticipated outcomes.

In conclusion, we define the concept of the spirit of information technology as the general intent with regard to values and goals underlying a given set of technical features. This differs a little from the definition of DeSanctis and Poole (1994), because in our view their distinction between the non-technical part and the technical part of technology is not sufficiently clear. A technology's spirit is the 'official line' regarding how to act when using a technology. A spirit provides signification, legitimation, and can be a means of domination. Office technology (and thus its spirit) can only be realized in actual use, which is refered to as appropriation. If, in a certain context, users do not appropriate an office technology in accordance with its spirit, this may lead to unanticipated outcomes. In this way, it can be theoretically understood why similar office technologies, even in similar contexts, can lead to different outcomes. Related ways of referring to a technology's spirit in this thesis will be through the use of terms such as 'underlying philosophy' or 'intention' of an information technology.

After having explained the concept of spirit, the following section elaborates further on the concept of appropriation.

\subsection{Office technology appropriation}

For the roots of the concept of appropriation, Poole and DeSanctis (1989) go back to Hegel and Marx ${ }^{6}$. These $19^{\text {th }}$ century philosophers were interested in how humanity progressively learned to control and shape the natural world and how this, in turn, influenced and changed human society. The nature of subject-

\footnotetext{
${ }^{6}$ Poole and DeSanctis are not the only researchers who have adopted the concept of appropriation. Ciborra (1996) also does, but uses Heidegger's "Being and time" (New York: Harper and Row, 1962) and Dreyfus' "Being-in-the-world" (Cambridge, MA: MIT press, 1994). Ciborra considers appropriation as a form of taking care of an innovation "fallen" in its context of use (p. 11). This concept of appropriation is basically the same as Poole and DeSanctis'; information technology is a 'trigger' for human behavior, but users of information technology are 'active agents', and effects come from their interaction with the technology. In our study we use the concept of appropriation as Poole and DeSanctis (1989) and DeSanctis and Poole (1994) define it, as this fits into the broader context of AST.
} 
object relationships was of utmost relevance in understanding this progression. Marx stressed the productive and self-constructing nature of humanity. In his view the concept of appropriation was the key that unlocked the nature of subject-object relationships. By appropriating an object, Marx meant that it was used constructively, incorporated into one's life, for better or worse (Ollman, 1971). Men and women in nature make their worlds through appropriating objects, and advances in modes of appropriation are the basis for advances of human society in general.

Placing advanced (information) technology in Marx's perspective, every effect of a certain technology is dependent on the appropriation of the technology. Appropriation of an object implies that a user realizes that object (Ollman, 1971). What an object is depends on how it is used, on how it enters into human activity. The implication of this view is that the realization of any object may differ with situation, and that the object itself can change as people change their mode of using it.

Poole and DeSanctis (1989) note that Marx's conception of appropriation, as a constructive use that shapes both user and object, needs to be elaborated further to be useful in the study of GDSS and other new technologies. Things are no longer as straightforward as Marx suggested, he used the contrast between tools, which are controlled by the craftsperson, and machines, which control and appropriate the worker, to explain his worldview. One could also comment that Marx seemed to consider people as products of their historical period, and tended to stereotype appropriation modes by class. Marx distinguished only two classes: workers and capitalists. By doing so, he ignored differences in appropriation between individuals, groups, or organizations. Despite this weakness, Marx's basic conception of appropriation is a useful starting point for an analysis of human use of information technology.

The next subsection provides a closer examination of appropriation as an important element in AST, and its application in the context of information technology.

\subsubsection{Appropriation in adaptive structuration theory}

AST considers information technology use as a matter of appropriation. In the relatively short history of AST, its developers have gone through some changes in the way they conceptualize appropriation. Initially, AST distinguished three dimensions of appropriation: faithfulness of appropriation, attitudes towards appropriation, and the level of consensus on the appropriation. However, after rethinking the theory of adaptive structuration, DeSanctis and Poole (1994) distinguish four dimensions of appropriation: appropriation moves, faithfulness of appropriation, attitudes towards appropriation, and instrumental uses. So, they added appropriation moves and instrumental uses, and removed consensus on 
appropriation. We believe that a combination of DeSanctis and Poole (1994) and Poole and DeSanctis (1990) provides the most useful concept of appropriation. We therefore include all the dimensions in our concept of appropriation.

So far, in our elaboration, we have adopted from AST the two central concepts; the spirit of office technology and appropriation. These concepts will be our main 'sources' in developing a research model that suits our study on office technology. However, office technology development, implementation and use, take place in a context, and so, in developing a research model, attention to this context is necessary.

\subsection{The context of office technology projects}

Analytically, the project process can be divided into three stages: the initial development stage, the institutionalized use stage, and the ongoing use stage (Orlikowski, 1991; Orlikowski and Robey, 1991). A main contextual factor, which can play a role in the distinct stages of the process, is the implicit or explicit office technology method applied. In the first, initial development stage, the method applied might especially reveal itself through the roles of the different parties involved, and the way these roles are fulfilled. The role of users in the first stage is a particularly important aspect, widely discussed in the literature, and therefore worthy of receiving attention. In the second and third stages, the institutionalized use stage and the ongoing use stage, the method applied might show itself in factors such as: the character of the implementation process, users' level of work autonomy after implementation, the level of change in the internal organizational environment that accompanies the implementation, organizational support during office technology use, and users' agreement upon the reason for office technology implementation.

Finally, since office technology projects are situated in a context, an office environment, newly implemented office technology might impact on the effectiveness of the work process. Hence, in the third, ongoing use stage, it is the contribution of the office technology to the effectiveness of work processes that is relevant.

Below, the factors mentioned above will be elaborated upon.

\subsubsection{Characteristics of the office technology development method}

In the first stage, the human actors involved start to work on developing the new system. Most companies have an implicit or explicit standardized way of developing new office technology. This so-called office technology development method influences the project as a whole, as it more or less frames the project process. 
A wide range of office technology development methods are available. There are, in fact, hundreds of different methods, and the number is still growing. livari et al. (1998) speak about a 'methodology jungle' (pp. 185). They refer to Jayaratna (1995) who estimates that there are more than 1000 information system development methodologies whose potential contributions are buried in the literature. Gasson $(1994 ; 1996)$ developed a framework for the selection of development methods and their application. She distinguishes between hard and soft approaches towards system development projects. A 'hard approach' sees a system development problem as relatively well defined: the objective is to satisfy the given requirements through the technical implementation of a closed system. A 'soft approach' sees the problem situation as ill-defined: the system is perceived as part of a wider social and political system and the task of the expert is to determine desirable and feasible changes by exploring and expressing the problem situation. In a 'hard approach' the concern is with the properties of a physical technical system, and it is assumed that human behavior can be modeled using rule-based systems, so the problem is analyzed by defining system objectives and requirements. A 'soft approach' is concerned with a system of human activity and so the problem is expressed, by examining elements of structure and process and their mutual relationship (Gasson, 1996, pp. 216).

It is likely that the consequences of applying a hard approach in office technology development and implementation will be different than if a soft approach. Based upon what we noted in chapter 1, it would seem likely expected that a hard approach is more likely to lead to office technology failure than a soft approach.

\section{The role of the main project parties}

According to the way AST conceptualizes information technology, the initial development stage is the stage in which the implicit or explicit intention of the technology, in other words its spirit, is 'created'. Parties involved in office technology projects, such as the management, IT experts, and users, express their ideas on what the new system should 'bring about'. Some of these ideas acquire a definitive form, while others are rejected and fade away. It is assumed that before a new system is 'offered' to users, a set of more or less definitive ideas has originated: the spirit. This can be a clear and consistent whole, or it can be unclear and inconsistent.

The influences of the roles of the management, IT experts and users lie in the issues they address in an office technology project. These issues can be very varied if observed at a detailed level. From a more abstract level, their contributions can be categorized into three main groups of issues that are addressed. Doherty and King (1998) distinguish the three following categories of issues: 
- performance contribution issues: this group of issues focuses on ensuring that a proposed system will make a positive contribution to the performance of some part of the organization. This can be in the form of contributing to the financial, marketing, or operational performance of the organization.

- organizational environment issues (or in short organizational issues): this group of issues concerns those which focus on the extent to which a system fits with its organizational environment. For example, the fit between a system and the organizational structure, the power distribution, and organizational culture.

- human issues: these issues focus on the impact of a system on working practices and the environment of individual employees. Examples of these issues are; human-computer interface design, ergonomics, health and safety issues and user motivation.

Initially, different parties may stress different categories of issues in office technology projects. For example, the management probably stresses mainly performance contribution issues, while users stress organizational environment and human issues. Furthermore, differences in what issues to emphasize can also depend upon what type of implicit or explicit office technology method is applied. With a hard approach towards office technology development, the main parties will probably stress performance contribution issues, while ignoring organizational and human issues. In a soft approach the opposite is likely to be the case.

\section{User involvement}

One party that is especially important is the user. As users are the ones who have to work with the office technology, it is important that they are aware of the office technology's spirit. We assume that user participation, or user involvement, in office technology development and implementation is a good way for users to contribute to the creation of this spirit and so to become aware of it. Many authors refer to the long existing assumption that user-participation is considered as a key factor in IT development and implementation (for example: Barki and Hartwick, 1994; Lin and Shao, 2000; Hunton and Beeler, 1997). In other words, the importance and relevance of user participation in fact is no longer disputed. However, in practice, the involvement of users in IT development is not without problems. We already discussed this briefly in the former subsection. User participation takes time and is not easy to organize appropriately, even though several academics developed participative methods (Mumford, 1993).

Lin and Shao (2000) summarize the following benefits found in literature:

- enhancement of system quality through a more accurate and complete identification of user information requirements; 
- knowledge and expertise about the organization the system is intended to support;

- avoidance of unacceptable or unimportant system features;

- better understanding about the system;

- increase in user acceptance of the system with a more realistic expectation about system capabilities,

- an opportunity for users and designers to resolve conflicts about design issues,

- users' feelings of ownership towards the system,

- a decrease in user resistance to possible changes incurred by the system,

- and a greater commitment from users.

All in all an impressive list, and it is therefore not strange that academics, and also practitioners, are ardent advocates of having users participate in IT projects. The question is whether user-participation also leads to a clearer image of the spirit of an office technology. Therefore, we will consider this further in our study.

Changes in the internal organizational environment

Implementations of office technologies can accompany changes in the internal organizational environment, but the level of this change can differ extensively in each situation. In chapter 1, we referred to Hornsby et al. (1992) who discern six 'problem-causing' issues regarding office technology projects. Two of these are related to the topic of organizational change. It is our basic belief that a change in an organization's IT system implies a change in the organization of work also. With this point of view, a lack of attention to the internal organization when introducing IT projects will at least be problematic. What happens in practice as we have seen so far does not leave us with an optimistic outlook. But is it really that bad?

Riesewijk (1989) carried out a study on the level of organizational change related to automation projects (Riesewijk used the term automation projects instead of IT projects). He placed the results of his survey on automation projects in a matrix and found that more than half (54\%) of the automation projects concerned follow-up automation projects with a low level of organizational change. Only $25 \%$ of the projects included a high level of organizational change. $21 \%$ of the automation projects in Riesewijk's study concerned initial automation projects (which it is reasonable to expect will have a considerable impact) with a low level of organizational change. This confirms the suggestion that automation projects are not really concerned with the impact on the organization of work, and that changes can unexpectedly occur from introducing new technology. 
In our study, the level of change in the internal organizational environment is considered to be an important contextual factor.

Users' work autonomy

Office technology implementations can 'match' differently to varying degrees the situations in hand. An important point to take into account is the level of work autonomy that users experience. It is our expectation that users with different levels of work autonomy will accept a newly implemented office technology differently. Users with little work autonomy might feel that they have no real alternative than to work with a given office technology, while users with much more work autonomy might feel that they can choose from a broader range of activities than only working with a given office technology. In other words, differences in the level of work autonomy suggest differences in office technology use

Users' satisfaction with the implementation process

Also relevant in the context of office technology development, implementation and use, is the implementation process itself. We think that appropriate support for IT implementation is a necessary pre-condition for effective usage (many literature sources assume a direct relationship between user training, users' support and information system use (Leone and Matarazzo, 1998). If users have been little, or even not at all, involved in an IT project, then the implementation will probably need careful attention. Users might show resistance to a new system and, to overcome this, appropriate attention to the users is necessary when they are first confronted with the system. If users have been quite heavily involved during a project, implementation might require less attention, as users are probably already a little used to the new system. In both cases, however, the implementation process of new office technology cannot be ignored since it is a factor that might have an influence on office technology use.

\section{Users' satisfaction with problem support}

Linked to this topic, but not identical to it, is the support users receive when they experience problems during office technology use. Office technology use can be positively influenced by good support from IT experts, help-desk employees, management etc. during use. Quite often, in practice, the implementation process finishes following the technical installation, and the support to users during ongoing use of new office technology is not adequately organized. This is more likely to be the case with a hard approach towards office technology development and implementation than with a soft approach. Nevertheless, good support of users, especially during ongoing use, can help in understanding the spirit of an office technology and, as a result, improve its appropriation. 
Users' satisfaction with the reasons for office technology implementation

The effects of office technology only arise during use, and thus are not a function of the technology itself. This line of thinking does not go beyond seeing the user of office technology as an 'intelligent' actor, or in Giddens' terms (1984), 'knowledgeable' agent. It means that users are able to reflect on their behavior, and hence are, to a large extent, able to know why they act as they do. Regarding office technology use, it implies that users' opinions about the reasons for implementing a new office technology might influence the relationship between the clarity of an office technology's spirit and office technology appropriation. We would expect that the relationship between a clear spirit and office technology appropriation is stronger among users who agree upon the reasons for office technology implementation.

\section{Work process effectiveness}

It is assumed that office technology is not implemented in organizations without reason. We suppose, if office technology is appropriated in accordance with its spirit, that the expected effects will arise. In general, the main reason for the implementation of office technology is to increase business performance (productivity, efficiency, quality of services). The relationship between new office technology implementation and business performance has been widely discussed in the literature, and still has not led to a clear answer (see for example: Hitt and Brynjolfsson,1996; Pinsonnealt and Rivard, 1998). We summarize the aspects mentioned as the effectiveness of the work processes. The problem with most of the studies which have been carried out on the topic of the influence of IT on effectiveness assume, implicitly or explicitly, that it is the IT itself that causes the expected effects. This is why these studies did not lead to clear and consistent answers. We assume it the actual use of office technology, referred to as appropriation, which causes specific effects. Therefore, it is our expectation that a high level of office technology appropriation contributes to the effectiveness of work processes.

\subsection{Towards a research model}

In this section we will combine the above-described 'ingredients' in a research model, which will then guide our study on office technology projects. For developing the research model we recall our central research question as, presented in chapter 1 :

How can office technology projects be improved by the use of the concepts of the spirit of office technology and office technology appropriation? 
In order to adequately answer this question, it can be divided into a number of sub questions.

1. How is the involvement of users in office technology projects related to the spirit of an office technology?

2. How is the spirit of office technologies related to the appropriation of office technologies by users?

3. How is the appropriation of office technologies related to work process effectiveness?

4. How do contextual factors influence the relationship between a certain spirit and office technology appropriation, and the relationship between office technology appropriation and work process effectiveness?

Earlier in this chapter, we stated that some information technologies might present a clear consistent spirit, whereas others will not. A clear coherent spirit is expected to direct appropriation in more or less pre-defined ways, whereas an unclear incoherent spirit can be expected to have a less directive impact on user behavior. This is where we think that the concepts of spirit and appropriation can be used to improve office technology development, implementation and use. We think the best point to start from in order to improve office technology projects is the clarity of the spirit to users and their level of office technology appropriation. To determine whether the clarity of the spirit is a useful point of departure in guiding office technology projects we formulate a number of hypotheses. These hypotheses will be tested, but not to look for 'universal laws' in social reality. In our view this is not possible as social reality is constituted by 'knowledgeable' human actors, who can reflect on their own behavior and thus are able to change it. We will test the hypotheses in specific office technology projects, in order to learn from these specific situations.

We formulate three basic hypotheses, two of which will be developed more specifically. The first hypothesis concerns an important issue in office technology projects: user involvement. As noted earlier, many authors refer to the long existing assumption that user involvement is seen as a key factor in office technology development and implementation (e.g. Barki and Hartwick, 1994; Lin and Shao, 2000; Hunton and Beeler, 1997). Based upon this assumption, many user-driven development methods have been developed, often as a reaction to technology-driven approaches. We want to find out to what extent user involvement clarifies the technology's spirit for them. We expect that if users are involved in office technology development and implementation, that they will experience an office technology's spirit more clearly than those who were not involved. This leads to the first part of our research model as shown in Figure 2.3. It emphasizes the role of users in relation to the clarity of an office 
technology's spirit, as they are the ones who have to work with the office technology. However, we also acknowledge that other parties, particularly the management and IT experts, play an important role in the 'creation' of the spirit of an office technology.

Approach towards office

technology development

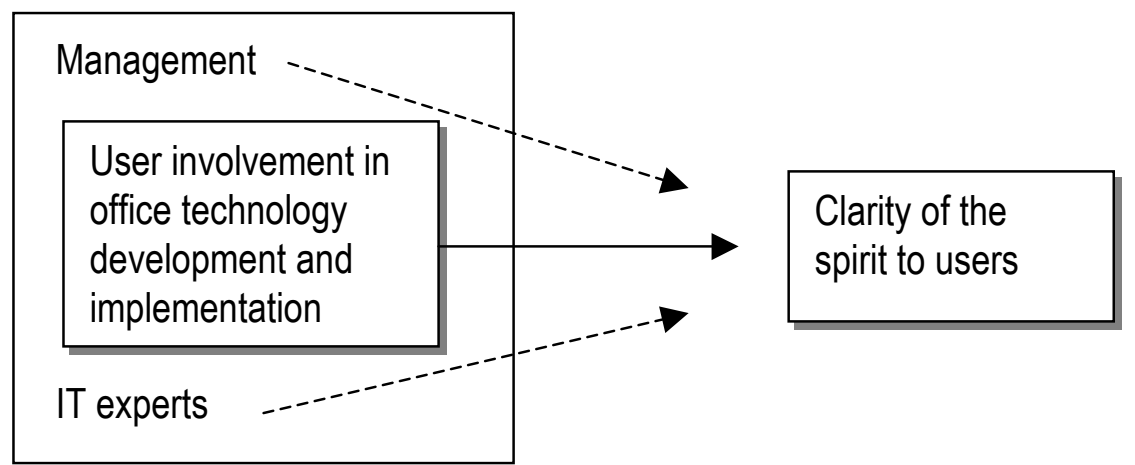

Figure 2.3 The first part of the research model

The hypothesis that follows from Figure 2.3 is:

1. Users who are involved in office technology projects, experience the spirit more clearly than users who are not involved.

The second hypothesis to be tested is based upon DeSanctis and Poole's expectation that a clear spirit will direct users towards appropriation in a more pre-defined way. We translate this into the following hypothesis:

2. The clarity of the spirit of office technology is positively related with the level of office technology appropriation.

This hypothesis forms the second part of our research model as presented in Figure 2.4. In this figure, the box containing the clarity of the spirit is surrounded by a dotted line representing the technical features of an office technology. Earlier in this chapter we explained that the technical features are the technical means through which users are expected to realize an office technology's spirit. 


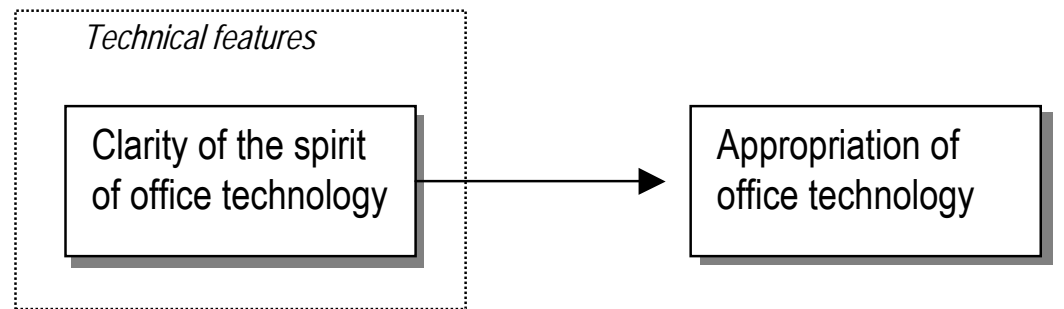

Figure 2.4 The second part of the research model

Thus, if users of an office technology experience the spirit to be clear, it can be expected that they will appropriate the office technology to a larger degree, than if the users do not clearly experience the spirit.

However, we also believe that the context of appropriation might stimulate or constrain the extent to which the clarity of spirit, to users, is related to office technology appropriation. AST recognizes 'sources of structures' that might influence technology appropriation, such as the internal organizational environment and the characteristics of users' tasks. We adopt these as two sources of structure that can support or constrain the relationship between the clarity of the spirit and the level of appropriation, but also include three other sources of structure which we consider relevant in office technology projects: users' satisfaction with the implementation process, users' satisfaction with the reasons to implement the office technology process, and users' satisfaction with their support over problems during office technology appropriation.

This leads to the following more specific hypothesis:

The relationship between the clarity of spirit and office technology appropriation is more positive among:

2a. users who are highly satisfied with the way new office technology is implemented;

$2 b$. users who strongly agree with the reasons for new office technology implementation;

2c. users who are highly satisfied with the organizational support during new office technology appropriation;

$2 d$. users who have experienced a high level of change in the internal organizational environment that accompanied new office technology project;

2e. users who experience a high level of work autonomy after new office technology implementation. 
These hypotheses are visualized in the third part of the research model as presented in Figure 2.5.

- Changes in the internal organizational environment;

- Level of work autonomy;

- Users' satisfaction with implementation process;

- Users' satisfaction with reasons for technology implementation;

- Users' satisfaction with organizational support.

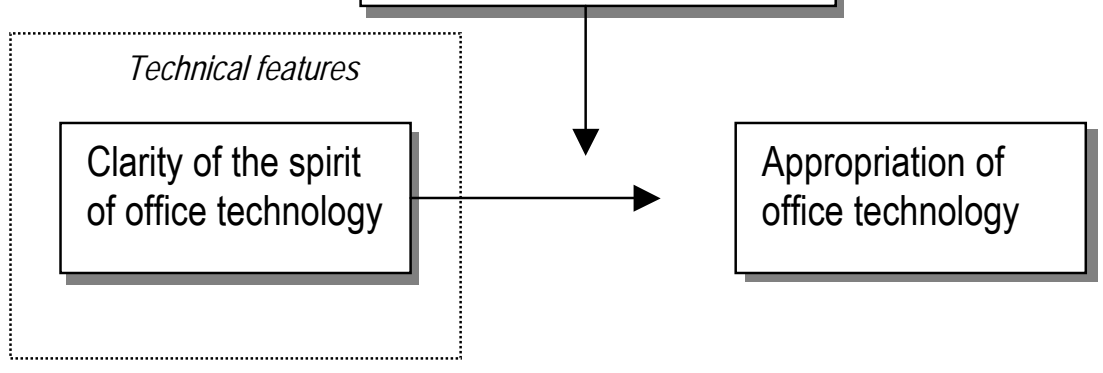

Figure 2.5 The third part of the research model

Our final hypothesis is concerned with the role of office technology appropriation in work process effectiveness. In general, the main reason for starting an office technology project is to increase business performance (productivity, efficiency, quality of services). We summarize this as the effectiveness of the work processes, as effectiveness in our opinion is: the extent to which work processes develop in a goal direction. In practice it is therefore the expectation that working with the new office technology will lead to an increase in work process effectiveness. We formulated this in the following way:

3. The level of office technology appropriation is positively related with the level of effectiveness of the work processes.

Figure 2.6 visualizes this hypothesis, the fourth part of the research model. 


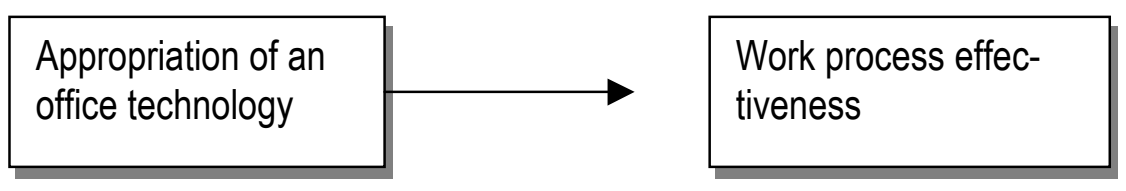

Figure 2.6 The fourth part of the research model

With an eye on aiming to support the context of office technology use, we again include the two sources of structure as proposed by AST: the internal organizational environment and the characteristics of the user tasks. These two might influence the relationship between office technology appropriation and work process effectiveness. This leads to the following hypotheses:

The relationship between the level of appropriation and work process effectiveness is more positive among:

3a. users who have experienced a high level of change in the internal organizational environment that accompanied new office technology implementation;

3b. users who experience a high level of work autonomy after new office technology implementation.

These hypotheses are presented in Figure 2.7 and are the last part of the research model.

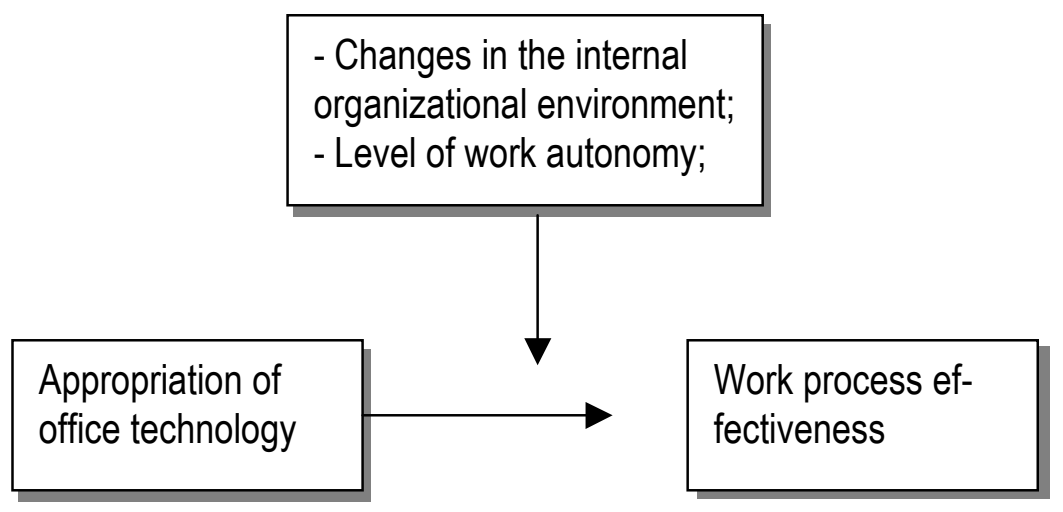

Figure 2.7 The last part of the research model

The whole research model is assembled on the following page.

Having explained the theoretical framework, in the following chapter we will continue by discussing the research method to be used. 
Approach towards office technology development
- Changes in the internal organizational environment; - Level of work autonomy; - Users' satisfaction with implementation process; - Users' satisfaction with reasons for technology implementation;

- Users' satisfaction with organizational support.
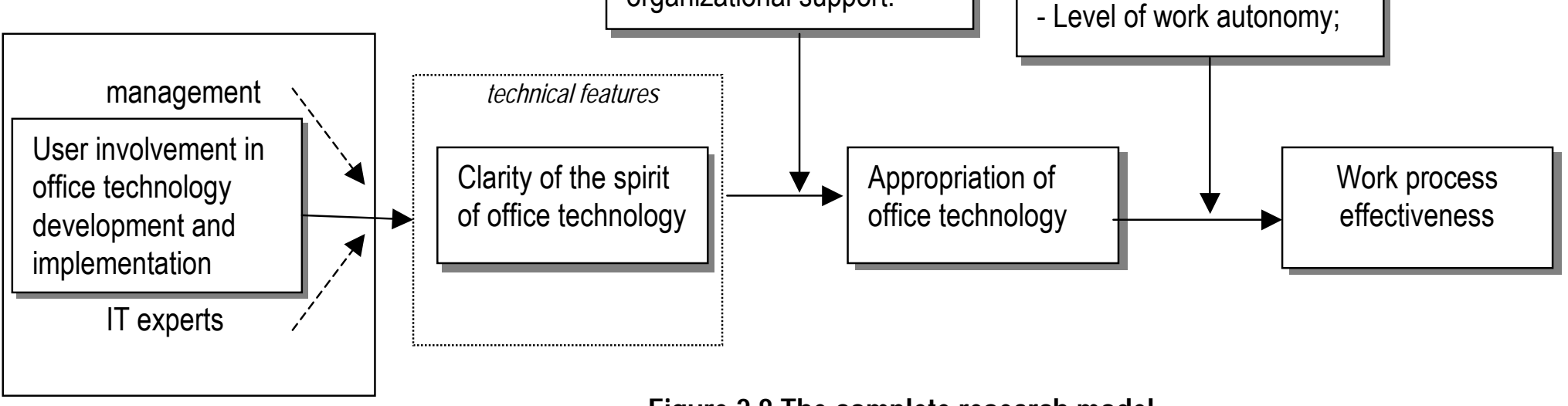

Figure 2.8 The complete research model 


\section{Three}

\section{Research method}

This chapter describes the research methods applied in this study. We start with a general elaboration on research methodology in relation to our theoretical framework. Then, our methodological point of view is explained, followed by a description of the methods and instruments that are used.

\subsection{From research model towards methodology}

The research model we developed in chapter 2 suggests a 'traditional' positivistic study. In a 'traditional' positivistic view, it is assumed that one can get to know more about universal relationships between variables in the social reality. It is a 'familiar' approach in carrying out research in some of the social sciences, in particular in psychology. Researchers in this field tend to think that they must uncover the 'hidden' universal laws of social reality, similar to in the natural sciences. Aiming for generalization is the main goal.

It is noteworthy, that many have concluded that research on IT in organizations has also been dominated by positivist studies (e.g. Francalanci \& Galai, 1998; Orlikowski \& Baroudi, 1991; DeSanctis \& Poole, 1994; Robey \& Boudreau, 1999). However, since the 1990s a greater diversity in research perspectives has emerged (Robey, 1996; Walsham, 1995). Some, for example Robey (1996), are of the opinion that diversity has certain advantages, but also some threats. Especially studies that apply an interpretive perspective have emerged the last 5 to 10 years (Walsham, 1995; Orlikowski \& Baroudi, 1991). A number of these were based upon Giddens' structuration theory. In Giddens' view, positivistic research, strongly connected with functionalism and to some extent with structuralism, over emphasizes the role of social institutions. Giddens critical attitude towards positivistic research would suggest that he is also critical of the research methods that are dominantly applied within this school of thought, such as quantitative research methods (used to search for causal relationships), but this is not the case! One of the central assumptions in structuration theory is that human beings, the object of study, are 'knowledgeable'; they know a great deal about why they act as they do. In this, Giddens' most important argument against functionalism and structuralism is contained. It is impossible for social scientists to find universal laws of human behavior as human actors are 'knowledgeable' and therefore able to change their behavior or broadly accepted rules of behavior. This is why, according to Giddens, the social sciences should not try to copy the natural sciences. 
Studying human behavior, in Giddens' view, cannot be separated from the actors themselves. Therefore, all social research has a necessarily cultural, ethnographic or anthropological aspect to it. The social scientist studies phenomena that are already interpreted. Observing human activity, for example human actors working with an office technology, is in fact observing acts that are already based upon interpretations of the human actor. Giddens' labels this as the double hermeneutic, which is an essential characteristic of the social sciences. Natural sciences 'only' have to deal with a single hermeneutic.

Although structuration theory calls for ethnographical methods in particular, Giddens does not totally reject other methods. He admits that ethnographical studies well suit research within the framework of structuration theory, but he also admits that more 'traditional', quantitative forms of research also suit well, provided they comply with the following conditions (Giddens, 1984b):

1. The 'quantitative' researcher has to give up trying to 'uncover' universal social scientific laws;

2. Social scientists must 'break' with the association of quantitative research and reasoning in terms of causality between social structures and human behavior;

3. Social scientists must reject the division between quantitative and qualitative research, or between statistical methods and interpretive methods;

4. Social sciences must not develop their own set of concepts 'disconnected' from "common sense"- knowledge. According to Giddens, the social sciences are dealing with a 'double hermeneutic', in contrast with the psychical sciences that are 'only' dealing with a 'singular hermeneutic'. That is: social sciences are confronted with a already interpreted reality (by human actors who are the subject of study), physical sciences are not.

We conclude that although Giddens' structuration theory tends towards a preference of qualitative research, it is not Giddens' intention to reject quantitative research. Quantitative research methods can be adequate and useful, provided they are untied from the underlying assumptions of functionalism and structuralism. As an alternative, DeSanctis and Poole (1994) propose soft-line determinism. In their view IT is a trigger for human action. They reject that IT determines human action. Hence, DeSanctis and Poole (1994) stress IT use; effects arise from the interaction between the user and IT.

Having discussed the methodological implications of structuration theory, we will now go deeper into the choices we make regarding research methods. 


\subsubsection{Our methodological choices}

In our study we chose a quantitative approach, 'encased' in a qualitative research design. The advantage of this is that we will not only present 'sterile' numbers and figures, but also describe their context. By doing so, we will achieve the basic aim of our study, which is to increase our knowledge of office technology development, implementation and use in order to improve it. This is reflected in our central research question. For this purpose, we have developed a research model in chapter 2 based upon concepts, which stem from AST. The model proposes relationships between the concepts. By gaining more insight into these relationships in different contexts, we believe our knowledge can increase. However, we do not assume that the relationships represent an everlasting causality. In this study we follow the line of DeSanctis and Poole (1994) and position this study methodologically in the soft-line deterministic tradition. This means that we acknowledge that structures have deterministic abilities, but that human actors can change them. They can decide not to act in pre-described ways, for example, as reflected in the spirit of an office technology. In other words, office technology is a trigger for human action that can lead to expected effects, but only if it is used in accordance with its intents and goals. It is not a 'force' that only allows one type of outcome.

In general, there are two main stereotypical beliefs regarding the differences between the quantitative and qualitative research traditions. Lee (1999) studied a number of recently articulated distinguishing characteristics and summarized them in the following two statements:

1. Qualitative research is often taken to be inductive, theory-generating, subjective, and non-positivistic. Quantitative research is often taken to be deductive, theory-testing, objective, and positivistic.

2. Some management researchers believe that these differences are so large that one must do either qualitative or quantitative research. In other words, it is not feasible to do both.

But stereotypes in nature do not represent reality, they are over simplifications. Qualitative research is not only useful for theory generation but also for testing. Yin (1994), for example, has shown, that qualitative research and quantitative research do not exclude each other, and can support each other.

The rest of this section describes how the specific methods and techniques in this study are approached.

\subsection{2 multi-method research}

In our study we opt to blend quantitative and qualitative research methods. Lee (1999) distinguishes three types of blending with quantitative and 
qualitative research: a two-phase design, a dominant-less dominant design, and a mixed-methodology design.

1. A two-phase design. In this model a quantitative study is followed by a qualitative study (or the reverse). This sequencing implies comparable standards of methodological rigor.

2. A dominant-less dominant design. This model consists of a qualitative study plus a small quantitative component (or the reverse).

3. A mixed-methodology design. In a mixed-methodology design, multiple qualitative and quantitative techniques can be applied. By selecting multiple techniques, the researcher creates a set of complementary data-gathering activities to compensate for the weaknesses of individual approaches.

We have opted for a mixed-methodology design. Both quantitative and qualitative techniques have their strengths and their weaknesses. For example, quantitative techniques, in general, lack the possibility gaining deep insights into phenomena, whereas qualitative techniques, in general, lack the possibility of including large numbers of respondents. For this reason a mix of techniques seems to be the best option for studying social scientific phenomena. The research model presented in chapter 2, and the hypotheses drawn from it, are intended to be tested. However, presenting only values and figures does not give an insight into their background. Especially, having positioned ourselves in soft-line determinism, stresses the need to pay attention to contextual factors in a more qualitative way. Maxwell (1996) offers three pragmatic considerations that, according to him, often act on researchers' decisions concerning the use of qualitative designs. Firstly, qualitative research can enhance the credibility of a study. Secondly, the study's results are often taken as understandable, believable, and meaningful. Thirdly, qualitative research designs can enhance organizational practices as participants and other organizational members can readily see the implications of the obtained results. An outcome of this is that organizations and organizational members might be more willing to cooperate.

It is partly these pragmatic considerations that decided us to opt for qualitative research. In chapter 2 we discussed our theoretical framework, which makes use of a set of concepts that we expect to be confusing to laymen. Approaching organizations for cooperation in a study based upon such a theoretical framework requires for a 'closer relationship' than in more 'distant', analytical quantitative research. The results of qualitative research, in which structuration theory is used, should be more acceptable to participants and other organizational members, since the results should be more understandable than results from 'traditional' quantitative research.

In line with the mixed-methodology design as distinguished, our research contains both a quantitative component and a qualitative component. The quantitative component is used for testing the hypotheses formulated in chapter 2. As explained earlier, the qualitative and the quantitative components are 
considered to be mutually supportive. We aim to test our research model, but within a case study framework. This means that the concepts in our research model will be measured in a quantitative way, but that we then present these measurements on a project by project basis. We also describe the variables of each project. In this way the 'values and the figures' are backed up by words. These give us a basis for explaining why certain relationships are as they are. We do not uncritically plead here for the use of both designs, but, if the research circumstances allow it, it is to be preferred. This is in contrast with what some researchers believe, that qualitative and quantitative research cannot be blended. In this thesis we will try to prove the opposite.

\subsection{The case study design}

\subsubsection{The case study method}

Yin's case study method is the second most often qualitative method mentioned in studies published in the organizational sciences (Larsson \& Lowendahl, 1996). The case study research method had had a bad name for some time because of the methodological arguments for choosing for case study research are often quite minimal (Den Hertog \& Van Sluijs, 1995). But since case study research has proven to be useful in theory building especially in the organizational sciences, the 'mood' is positively changing over years.

We do not think it is necessary to fully elaborate here on the case study method as such, as there are a number of good overviews available (e.g. Yin, 1994; Lee, 1999; Hutjes \& Van Buuren, 1992). This section just develops our specific application of this method.

A case study has five main components (Lee, 1999): 1. Research questions, 2. Theoretical propositions, 3. Units of analysis, 4. The logic linking data to these theoretical propositions, and 5 . The criteria for evaluating these propositions.

Having these five components should guarantee that our case study will be seen as "proper". With regard to the first component; our study's central research question has been presented in chapter 2. Chapter 1 and chapter 2 "focused the lens" which will be applied in this study, and therefore the second component has also been properly addressed. The third component, deciding about the unit of analysis, needs further explanation. The unit of analysis indicates the phenomenon that is to be studied. The difficulty with case study research is the isolation of the phenomenon from its broader context. Good solutions are not readily available, so that it is important to be as explicit as possible in defining the unit of analysis. The unit of analysis we choose for our study is office technology projects. 
The fourth component, the logic linking data to the theoretical propositions, concerns a study's specific techniques. In other words; how does a researcher collect the data appropriate for finding answers to the research questions or testing the theoretical propositions? The way we will tackle this question is discussed in subsection 3.3.3.

The fifth component, the criteria for evaluating these propositions, will be discussed in subsections 3.3.4. and 3.3.5.

\subsubsection{Case selection}

The unit of analysis that is chosen for this study are office technology projects, which means that a single office technology project is considered as a case. It is this study's goal to say something about office technology development, implementation and use, or in other words, office technology development, implementation and use make up our empirical domain. Therefore we consider it important to include a variety of office technology developments, implementations and uses in our study. We aimed to include different types of office technologies, so that a range of office technologies is represented in this study. In particular we included examples of what O'Brien (1995) (Table 1.1) calls electronic imaging/document management systems, and office management systems. These types of systems have the dearest impacts on users' work situation and are used in procedural offices (Panko, 1984).

It is not this study's intent to generalize in a statistical way across office technology projects. This is only an aim within each office technology project. The intent is to generalize theoretically (Yin, 1994). Therefore, we have chosen four office technology projects that concern office technologies of the types mentioned above.

As the term 'office technologies' refers to a range of more specific technologies, we believe that to cover this range adequately we must include a number of office technology projects involving different types of office technology. In chapter 1 an overview was presented of types of office technologies (Table 1.1). We have selected projects of two types from within the following categories: electronic imaging/document management systems, and office management systems. More specifically, it involves four projects to implement the following technologies: a document imaging system combined with a workflow management system, a call center agent supportive system, an insurance administration system, and an electronic calendar management system. To ensure some possibility of comparability in the context of these projects, all of them take place within service-oriented organizations. 
Within the case study approach, specific techniques have to be selected for collecting the data. One of the components of the method is that the data collected must be suitable for answering the research questions and for testing the hypotheses. As noted earlier, our research is basically of a soft-line deterministic nature, as our research model, is based on AST.

We have several techniques at our disposal, such as conversational interviews, non-conversational interviews or written questionnaires, participant observation, and document analysis. For our study we have chosen conversational and non-conversational interviews (written questionnaires) as the dominant techniques. The conversational interviews particularly are used to describe the variables in the research model, the non-conversational interviews are used for testing the hypotheses which represent the relationships between the variables in the research model.

Conversational interviews are adequate for the following reasons. Firstly, we studied office technologies retrospectively. Because of time constraints it was not possible to participate in a number of office technology projects from start to end. Secondly, through the use of conversational interviews with representatives of all groups of participants, it was possible to reconstruct the office technology projects from start to end. In this sense, the conversational interviews are used as an instrument for ethnographical purposes. 'Traditional' ethnographical methods concern participant observation within a specific context, often for a considerable a period of time; the researcher is in fact the research instrument. Because of the practical constraints it was not possible to participate in a number of office technology projects over a period of time. Therefore we had to choose an alternative; we used project participants who had been able to observe the project as 'researchers' and let them tell their story. As this includes representatives of all the project parties, we have a so-called multi-view of the project, and are able to describe the variables as discerned in our research model. The non-conversational interviews, which we will refer to as questionnaires from now on, were used to test our hypotheses.

Besides the two types of interviews as the dominant techniques, and the analysis of documents as additional techniques, we also used immediate participant observations as a source of data. As explained, it was not possible to be constantly present in the projects, but in all of them we observed a number of users of the newly implemented office technology over a short period of time. The data collected in this way is in addition to the data obtained from the dominant techniques. How we developed the instruments for use in the case studies is described below. 


\subsection{Instrument development and operationalization of variables}

\subsubsection{The conversational interviews}

We chose to use conversational interviews to collect the data for describing the variables discerned in our research model. These interviews were of a semi-structured character. The topics we selected to discuss were based upon our research model. We asked respondents to talk about the office technology project from its start to its end (divided into the three stages as distinguished: the initial development stage, the institutionalized use stage, and the ongoing use stage) guided by the list of variables in our research model. For each topic we dug more deeply if necessary. The table below presents the definitions of the main variables in the research model and the way they were operationalized.

\begin{tabular}{|c|c|c|}
\hline concept & definition & Indicators \\
\hline $\begin{array}{l}\text { (office technology } \\
\text { development) } \\
\text { Method } \\
\text { characteristics }\end{array}$ & $\begin{array}{l}\text { The main elements of the process } \\
\text { in the creation of an office } \\
\text { technology }\end{array}$ & $\begin{array}{ll}- & \text { Development priorities } \\
\text { - } & \text { Extent of user participation } \\
\text { - } & \text { Approach to problem } \\
\text { investigation } \\
\text { - } & \text { Modeling approach } \\
\text { - } & \text { Control of development } \\
& \text { processes } \\
\text { - } & \text { Project life cycle time scale } \\
\text { - } & \text { Project life cycle model }\end{array}$ \\
\hline $\begin{array}{l}\text { Management } \\
\text { contributions }\end{array}$ & $\begin{array}{l}\text { The issues emphasized by the } \\
\text { management of a project } \\
\text { organization during the } \\
\text { development of an office } \\
\text { technology }\end{array}$ & $\begin{array}{llr}- & \text { Performance } & \text { contribution } \\
\text { issues } & \\
\text { - } & \text { Organizational } & \text { alignment } \\
& \text { issues } & \\
\text { - } & \text { Human issues } & \\
\end{array}$ \\
\hline $\begin{array}{l}\text { IT } \quad \text { expert } \\
\text { contributions }\end{array}$ & $\begin{array}{l}\text { The issues emphasized by IT } \\
\text { experts in a project organization } \\
\text { during the development of an office } \\
\text { technology }\end{array}$ & $\begin{array}{llr}- & \text { Performance } & \text { contribution } \\
\text { issues } & \\
\text { - } & \text { Organizational } & \text { alignment } \\
& \text { issues } & \\
\text { - } & \text { Human issues } & \end{array}$ \\
\hline User involvement & $\begin{array}{l}\text { The behaviors, assignments, and } \\
\text { activities that users or their } \\
\text { representatives perform during } \\
\text { office technology system } \\
\text { development and implementation. }\end{array}$ & $\begin{array}{ll}\text { - } & \text { extent of providing information } \\
\text { - } & \text { opportunity to give advice } \\
\text { - } & \text { participation in decision } \\
\text { making } \\
\text { - } \\
\text { control over decision-making } \\
\text { process }\end{array}$ \\
\hline
\end{tabular}

Table 3.1 Definitions and operationalization of concepts in the research model (continued on next page) 


\begin{tabular}{|c|c|c|}
\hline concept & definition & indicators \\
\hline $\begin{array}{l}\text { Clarity of the } \\
\text { spirit of office } \\
\text { technology (OT) }\end{array}$ & $\begin{array}{l}\text { The extent to which the general } \\
\text { intent regarding the values and } \\
\text { goals underlying an office } \\
\text { technology's set of technical } \\
\text { features is clear to users. }\end{array}$ & $\begin{array}{ll}\text { - } & \text { (clarity of) the technology's } \\
\text { goals } \\
\text { - } \\
\text { (clarity of) the 'thought behind' } \\
\text { an office technology } \\
\text { - } \quad \text { knowing where effective use } \\
\text { of an office technology leads } \\
\text { to } \\
\text { - } \quad \text { knowing what developers } \\
\text { aimed for } \\
\text { - knowing how an office } \\
\text { technology is used optimally }\end{array}$ \\
\hline $\begin{array}{l}\text { Technical } \\
\text { features }\end{array}$ & $\begin{array}{l}\text { The visible, technical capabilities } \\
\text { users are offered being a part of an } \\
\text { office technology. }\end{array}$ & $\begin{array}{ll}- & \text { Level of restrictiveness } \\
\text { - } & \text { Level of sophistication } \\
\text { - } & \text { Degree of } \\
& \text { comprehensiveness }\end{array}$ \\
\hline Appropriation & $\begin{array}{l}\text { The physical and mental activities } \\
\text { that users of office technology } \\
\text { carry out while making a selection } \\
\text { from the potential set of structures } \\
\text { of an office technology, } \\
\text { represented by the spirit and the } \\
\text { technical features, for the day-to- } \\
\text { day practices. }\end{array}$ & $\begin{array}{ll}- & \text { Actual use (moves) } \\
- & \text { Use in line with the spirit } \\
\text { (faithful appropriation) } \\
-\quad \text { Usefulness of an office } \\
\text { technology } \\
-\quad \text { Ease of use of an office } \\
\text { technology } \\
-\quad \text { Instrumental use of an office } \\
\text { - } & \text { technology } \\
\text { Consensus about use }\end{array}$ \\
\hline $\begin{array}{l}\text { Work process } \\
\text { effectiveness }\end{array}$ & $\begin{array}{l}\text { The extent to which the day-to-day } \\
\text { activities of the group of users of } \\
\text { an office technology have to be } \\
\text { carried out to meet the standards } \\
\text { required. }\end{array}$ & $\begin{array}{l}\text { - } \\
\text { speed of work processes that } \\
\text { can be achieved with the } \\
\text { technology but need not be } \\
\text { compulsory } \\
\text { - } \quad \text { the level of errors } \\
\text { - } \quad \text { the amount of executed work }\end{array}$ \\
\hline $\begin{array}{l}\text { Changes in the } \\
\text { internal } \\
\text { organization that } \\
\text { accompanied the } \\
\text { project }\end{array}$ & $\begin{array}{l}\text { Changes in tasks, physical work } \\
\text { environment, group composition, } \\
\text { and performance criteria that may } \\
\text { occur along with the office } \\
\text { technology implementation }\end{array}$ & $\begin{array}{ll}\text { - } & \text { changes in tasks } \\
\text { - } & \text { changes in physical work } \\
\text { - } & \text { environment } \\
\text { - } & \text { changes in group composition } \\
\text { changes in output criteria }\end{array}$ \\
\hline
\end{tabular}

Table 3.1 Definitions and operationalization of concepts in the research model (continued on next page) 


\begin{tabular}{|c|c|c|}
\hline concept & definition & indicators \\
\hline $\begin{array}{l}\text { Users' } \quad \text { work } \\
\text { autonomy }\end{array}$ & $\begin{array}{l}\text { The space users have in their day- } \\
\text { to-day work to decide how to } \\
\text { arrange their tasks. }\end{array}$ & $\begin{array}{l}\text { - } \quad \text { the possibility to determine the } \\
\text { amount of work to carry out } \\
\text { - } \quad \text { the possibility to determine the } \\
\text { sequence of tasks } \\
\text { - } \quad \text { the possibility to determine the } \\
\text { speed of work }\end{array}$ \\
\hline $\begin{array}{l}\text { Users' } \\
\text { satisfaction with } \\
\text { OT } \\
\text { implementation } \\
\text { process }\end{array}$ & $\begin{array}{l}\text { Users' agreement upon the way an } \\
\text { office technology is implemented. }\end{array}$ & $\begin{array}{l}\text { the level of satisfaction with } \\
\text { the way of implementing, its } \\
\text { duration, and the training }\end{array}$ \\
\hline $\begin{array}{l}\text { Users' } \\
\text { satisfaction with } \\
\text { organization } \\
\text { support during } \\
\text { OT appropriation }\end{array}$ & $\begin{array}{l}\text { Users' satisfaction with the help } \\
\text { and coaching regarding learning to } \\
\text { work with an office technology }\end{array}$ & $\begin{array}{l}\text { - } \text { the level of satisfaction with } \\
\text { the support from the } \\
\text { organization when problems } \\
\text { occur while using an office } \\
\text { technology }\end{array}$ \\
\hline $\begin{array}{l}\text { Users' } \\
\text { satisfaction with } \\
\text { the reasons for } \\
\text { OT } \\
\text { implementation }\end{array}$ & $\begin{array}{l}\text { Users' agreement upon the } \\
\text { reasons for developing and } \\
\text { implementing a new office } \\
\text { technology. }\end{array}$ & $\begin{array}{l}\text { - } \quad \text { the level of satisfaction with } \\
\text { the reasons for implementing } \\
\text { an office technology }\end{array}$ \\
\hline
\end{tabular}

\section{Table 3.1 Definitions and operationalization of concepts in the research model}

Table 3.1 functioned as a list of topics for the conversational interviews. In order to characterize the office technology development methods applied in projects we followed the framework of Gasson (1994) who discerned the indicators given in the top row of Table 3.1. Because these indicators use a specific terminology adopted from IT development methodology literature, these indicators are briefly explained below.

- Management development priorities: the extent to which the development of a new office technology aims to realize technical optimization or improve the work and social system 'design'.

- Extent of user participation: The extent to which users are involved in an office technology project

- Approach to problem investigation: the extent to which the problem situation is defined in a top-down way (based upon the belief that a problem can be divided into sub-problems, which in turn are broken down until a level is reached where a computer-based solution can be identified for each of the problems' 
component), or bottom-up (based upon a holistic work process belief; a problem is not only technical, but also social, political etc.).

- The approach to system modeling: The extent to which the system requirements are presented as a set of functions which must be performed by the system to meet its objectives, or as a set of human work processes, which meet the objectives of the system.

- Control of development processes: The extent to which the management control exerted is formal and structured, expressed by a document-driven process, or informal and unstructured, expressed by permitting wider interaction, between technical developers and users, and others involved.

- Project life cycle time scale: The extent to which the life cycle time scale is long (resulting in a 'big bang' scenario of implementation), or short (often resulting in a phased roll-out).

- Project life cycle model: The extent to which a project applies a 'waterfall' model, where each stage of the development process is considered complete before the next stage begins, or an 'evolutionary' model, where the development process is considered as a set of short cycles. As each cycle ends, another cycle begins.

As explained in chapter 2, Gasson $(1994 ; 1996)$ placed these aspects on a continuum with at the one end 'a hard approach towards system development projects' and at the other end 'a soft approach towards system development projects'. Table 3.2 present Gasson's framework:

\begin{tabular}{|l|l|}
\hline Characteristic & \multicolumn{1}{|c|}{ 'Hard' vs. } \\
\hline $\begin{array}{l}\text { Management } \\
\text { development priorities }\end{array}$ & $\begin{array}{l}\text { Technical optimization vs. improvement of work and } \\
\text { social system 'design' }\end{array}$ \\
\hline $\begin{array}{l}\text { Extent of user } \\
\text { participation }\end{array}$ & Low vs. High \\
\hline $\begin{array}{l}\text { Approach to problem } \\
\text { investigation }\end{array}$ & Top-down vs. bottom-up \\
\hline Modeling approach & Function-oriented vs process-oriented \\
\hline $\begin{array}{l}\text { Control of development } \\
\text { processes }\end{array}$ & Formal vs. informal \\
\hline $\begin{array}{l}\text { Project life cycle time } \\
\text { scale }\end{array}$ & Long vs. short \\
\hline Project life cycle model & Waterfall vs. evolutionary \\
\hline
\end{tabular}

Table 3.2 Framework to describe the development method characteristics (Gasson, 1994)

With regard to describing the way users are involved, we used the indicators given in Table 3.2, but placed them on a scale from low to high. This is 
based upon the idea of Heller et al. (1998). In each case, we discerned the project phases undertaken (implicitly or explicitly) by the project management, and judged the level of user involvement. This was based upon the data collected in the interviews. This judgement on the level of user involvement was placed on Heller's six point scale, which reflects the extent of influence: $1=$ no or minimal information, 2 = information, $3=$ opportunity to give advice, 4 = advice taken into consideration, $5=$ joint decision making, $6=$ complete control.

We investigated the characteristics of the technical features of an office technology by using three criteria: the level of restrictiveness, the level of sophistication, and the level of comprehensiveness. The level of restrictiveness concerns the set of possible actions users can take with the technical features. The level of sophistication concerns the level of interaction supported by the technical features. For example: do the features only support individual actions, or do they support highly interactive actions between users. Finally, the level of comprehensiveness concerns the number of number and variety of features offered to users.

The conversational interviews with respondents were sometimes audiotaped, and sometimes immediately transcribed with the help of a laptop computer. Interviews generally lasted at least one and a half hours and some respondents were interviewed twice. After the interviews we let the respondents check the transcripts and correct them if necessary. In the case study descriptions information is added about the persons who were interviewed (see chapters 4-7). The topics that guided the interviews was based upon Table 3.1

So far, we have explained the development and the execution of the conversational interviews. In the following subsection the development of the non-conversational interviews will be discussed.

\subsubsection{The non-conversational interviews}

The relationships between the variables in the research model developed are tested by using results from the questionnaires. Chin et al. (1997) proposed developing scales for the central constructs of AST in order to measure them more easily. We follow this approach in our study. Constraints with available time, labor and budget were a factor in this decision. In addition, we believe that using scales for measuring AST concepts is innovative in the sense that for the concept of clarity of spirit, as far as we know, never before has a scale been developed and used. It is also the first time that the complete concept of appropriation has been measured with the help of scales, and that AST has been applied for studying other technologies than group decision support systems. We will now elaborate on the scale development for each concept. 


\section{User involvement}

As noted earlier, user involvement refers to behaviors, assignments, and activities that users, or their representatives, perform during information system development. We used two self-constructed single-item scales to measure user involvement. One scale refers to the extent of the influence of the respondent on the development, the other refers to the extent of the influence of the respondent on the implementation. Example of an item: I had influence on the implementation process of [name of the system].

\section{Clarity of the spirit}

For measuring the clarity of spirit, the five aspects of appropriation, experienced changes in the work situation, experienced work autonomy, and effectiveness of work processes, we to an extent developed scales ourselves and partly used existing scales. The scale for measuring the clarity of spirit was developed on the basis of our definition of spirit, as inspired by DeSanctis and Poole (1994) and Poole and DeSanctis (1990). We formulated five items, and tested them with colleague-researchers. The items for this scale were formulated as propositions about whether respondents are clear on the goals of the new system, whether the 'thought behind' the new system is clear, and whether respondents know what effective use of the new system should lead to. An example of an item for this scale is: I know what effective use of [name of the system] should result in. The reliability of the scale was very satisfactory (Cronbach's alpha is 0.87 )

\section{Appropriation}

The concept of appropriation consists of five dimensions: appropriation moves, faithfulness of appropriation, attitudes towards appropriation, instrumental uses, consensus on appropriation.

DeSanctis and Poole (1994) define appropriation moves as the ways that users choose to appropriate the available technology structures. They propose four types of appropriation moves. In the context of our study we are especially interested in the level of appropriation moves, or in other words, how intensively do users appropriate office technology?

Faithfulness of appropriation is defined as the extent to which a certain office technology is appropriated consistent with its spirit.

By attitudes towards appropriation we mean the users' assessments of the extent to which the structures within the system are useful and easy to use. Attitudes set the tone for system usage and can reinforce productive or counterproductive trends in a group's experience with the system (Poole and DeSanctis, 1990).

Instrumental uses are another aspect of the concept of appropriation, referring to the reasons why systems are used. For example, users might only 
use a system for task completion, but they could also use it in an explorative way, or for individual personal purposes. DeSanctis and Poole (1994) distinguished seven purposes for which a group decision support system could be used: the task, communication or other group processes, exerting power, for establishing or maintaining social relationships, for individual/personal purposes, for fun and/or in an exploratory way, or at moments of confusion in a group. As group decision support systems are not our study's focus, not all of these types are useful here. In our study we intend to apply AST to office technology used by individuals in an organizational setting. Therefore we believe that only taskoriented use and exploration-oriented use are relevant. In line with the theoretical framework of AST, it is assumed that the clearer the spirit of a certain system is to users, the more task-oriented will be its use. When the spirit is not clear, users will more likely have a more explorative orientation.

Finally, the fifth aspect we distinguish on appropriation is consensus towards appropriation. The definition we apply is as follows: the extent to which users of office technology agree upon how the technology should be used. In order to achieve effective processes and desired outcomes, it is important that a specific office technology is used in a similar way by all users. Poole and DeSanctis $(1989,1990)$ assume that, especially with groups using group decision support systems consensus on how to appropriate the system is important. If there is a lack of agreement, then appropriations may vary in terms of the nature and degree of conflict. We believe that a high level of consensus is necessary, not only for the use of GDSSs, but also for office technology use. For example, if in an insurance company, employees who work with a specific office technology do not use it in a similar way, this will probably lead to ineffective work processes. Therefore, whether users of office technology are linked with each other very closely, or they work more as individuals, for the effectiveness of the work processes as a whole, it is important that there is consensus on how to use the technology.

The scales used for the aspects of appropriation were partly developed by ourselves, and partly adopted from others. For measuring the first aspect of appropriation, appropriation moves, we used a single item. As we are interested in the level of appropriation in the context of this study, we modified the aspect of appropriation moves. In the questionnaire, we did not focus on the types of appropriation moves, but on the level of moves (for respondents 'moves' was replaced by 'use'). This seems to be more in line with DeSanctis and Poole (1994) who hypothesized that it is the level of appropriation moves that is of importance with regard to the outcomes of ICT appropriation. When the number of appropriation moves is high, the desired effects can be expected, naturally taking into account the levels for the other aspects of appropriation.

To investigate this, the questionnaire contained the question: To what extent do you use [the name of the system]? 
The scale for faithfulness of appropriation was based on Chin et al. (1997), but we added three extra items, in order to enhance the scale. Based on the results of a reliability test all the eight items seemed valid. An example of an item for this scale is: I use [name of the system] in a different way to the original goals. The reliability of the scale was satisfactory (Cronbach's alpha is 0.77 ).

Attitudes towards the technology were measured by using two scales based on Davis (1989) and Sambamurthy \& Chin (1994): a five-item scale for measuring perceived usefulness, and a five-item scale for measuring perceived ease of use. We changed some elements of the scales, such as formulations of items, as we believed that they could be improved. An example of an item from the 'perceived usefulness' scale is: The [name of the system] is useful for my work. An example of the 'perceived ease of use' scale is: The screens of [the name of the system] are easy to understand. The reliability of the scales were very satisfactory (Cronbach's alpha for the scale 'perceived usefulness' is 0.85 ; for the scale 'perceived ease' of use it is 0.82 ).

We measured two types of instrumental use: task-oriented use and explorative use. Each was measured with a self-constructed four-item scale. An example from the 'task oriented use' scale is: If I use [the name of the system], then I know in advance for what task I want to use it. An example of the 'explorative use' scale is: During my work it takes me time to discover [the name of the system]. The reliability of the scale 'task oriented use' was moderately satisfactory (Cronbach's alpha 0.64 ), for the scale 'explorative use' the reliability was satisfactory (Cronbach's alpha 0.77).

Consensus on appropriation was measured with a self-constructed sixitem scale. An example from the 'consensus' scale is: There are implicit or explicit rules about how to work with [the name of the system]. The reliability test of this scale gave a satisfactory result (Cronbach's alpha 0.70 ).

\section{Effectiveness of work processes}

Effectiveness of the work processes is defined as the extent to which work processes that are carried out with the office technology are achieving their goals, are efficient, and occur with a low level of error. We measured effectiveness of work processes with a self-constructed four-item scale. An example of an item on the scale used is: Within the group of users of [the name of the system] the level of errors is low. The result of the reliability test is satisfactory (Cronbach's alpha is 0.73 ).

\section{Contextual factors}

By Change in the internal organization that accompanied the project we mean the changes in tasks, physical work environment, social work environment, and performance criteria that may occur along side with the office technology implementation. This is measured with a self-constructed four-item scale 
(Cronbach's alpha 0.73). An example of an item on the scale used is: With the implementation of [the name of the system] changes have taken place in the tasks for which I am responsible.

Users' work autonomy reflects the space users have in their day-to-day work to decide how to arrange their tasks. This is measured with a selfconstructed three-item scale (Cronbach's alpha 0.83). An example of an item used with this scale is: I can determine the amount of work I want to carry out myself.

Users' agreement with the reasons for new office technology development reflects the users' support for the decision to develop and implement a new office technology. This is measured with a self-constructed one-item scale. The item used is: To what extent are you satisfied with the reasons for implementing [the name of the system]?

Users' satisfaction with office technology implementation. This is the users' positive attitude to the way the new office technology is 'offered' to users, specifically reflecting user training, the duration of the implementation, and the process of implementation. This is measured with a self-constructed four-item scale (Cronbach's alpha 0.77). An example of an item used is: To what extent are you satisfied with the training about [the name of the system]?

Users' satisfaction with organizational support during appropriation. This shows the users' satisfaction with the help and coaching they receive regarding learning to work with the new office technology. This is measured using a selfconstructed single-item scale. The item used is: To what extent are you satisfied with the support from the organization when there are problems working with [the name of the system]?

All scales were measured with a five-point response format ranging from 5 = "strongly agree" to 1 = "strongly disagree". The scales used can be found in Appendix 1. It was our intention to use the first case study to test the scale reliabilities, and then improve the scales. However, this did not seem necessary, as the scale reliabilities were adequate (the scales' internal consistency were very satisfactory; Appendix 2 contains the relevant statistics).

One could counter that using scales simply presents a one-momentmeasurement and therefore is not a very information-rich look into the situation. We do not agree on this since we do not believe that respondents respond to statements based upon only their current situation, but, implicitily or explicitily, that they take into consideration a certain time span in making their judgements. Then one could argue that some respondents may have a bad day and so still 
give extremely low scores, which would give an incorrect picture of the situation. Our counter is that even if this did occur then it is equally possible that another respondent has an extremely 'good' day and therefore responds over positively. These two scores can then cancel on so that the mean score of the group of users as a whole will give a fair picture.

We agree with Anthony Giddens' view that quantitative measurements are adequate for empirical research provided the researcher involved is not aiming for universal laws of human behavior. Our research intends to find out if, in the time/space situation at hand, the relationship exist as expected, we will not claim that any relationships found represent "everlasting" universal relationships between variables in social reality. They will be considered as unacknowledged conditions of human activity only in the situation that is studied. The 'knowledge' we hope to provide can influence 'knowlegdeable agents' in organizations and may lead to changes in behavior. Therefore the knowledge we will provide is in some sense temporary. Then the question can posed: what is the usefulness of the "temporary" knowledge provided by this research? In our opinion this study can provide insights of use to 'knowledgeable agents' to assist them in understanding certain aspects of office technology development, implementation, and use.

\subsection{The case report}

In previous sections we have discussed how we have decided to blend qualitative and quantitative research methods in a mixed-methodology design. We also discussed the specific techniques we used and the concepts. Having discussed these, a final issue remains: how will the case reports be structured?

First of all, we have analyzed the data, initially for each office technology project, since we consider each project to be a case. Earlier in this chapter, we noted that we studied four office technology projects which concerned different types of office technology: a document imaging system in combination with a workflow management system, a call center agent support system, an insurance policy administration system, and an electronic calendar management system. After analysing each case separately, we executed cross-case analyses: one from a qualitative point of view and from a quantitative point of view.

Single data case analysis

The data collected through the conversational interviews, documents, and observations were analyzed by using categorization. We categorized the responses to the questions in the interviews, the documents, and the observations in line with the indicators of the variables as discerned. Meaningful categorization occurred also took place with the data derived from the questionnaires that 'investigated' the concepts in hypotheses. In fact, by 
completing in the questionnaires opinions were automatically categorized. To test whether the relationships between concepts existed as formulated in hypotheses we used Pearson product-moment correlation. For each case, only the three basic hypotheses were tested statistically, as the data sets for each case were to small to test all the sub-hypotheses. Instead we have used the qualitative data to explain why certain relationships are not in line with the expectations. In the cross-case analysis, discussed in chapter eight, the subhypotheses are tested statistically.

\section{Cross-case analysis}

After having analyzed the data from each case we carried out a crosscase analysis, in order to highlight the differences and similarities between the four cases. This provides insights that cannot be provided by separate caseanalyses, especially when it comes to generalizations. However, as noted earlier, we do not intend to provide sweeping generalizations in the 'traditional' positivist way. Our generalizations must be considered as restricted to the specific time and space conditions of our study. The results might however be adopted by human actors in the field and influence their future behavior.

For the qualitative cross-case analysis we compared the results from the separate cases. For the quantitative cross-case analysis we created a single database of the quantitative data from the separate cases and tested our hypotheses. The results were compared with the expectations as formulated in the hypotheses.

So far we have explained the methodology applied in our study. The following four chapters will present the case studies that were executed (one per chapter). Each chapter's introduction will briefly note some details of the methodology related to a specific case study. 


\section{Four}

\section{A digital information system/ workflow management system project}

\subsection{Introduction}

Our first case study concerns an office technology project, named "Verdi", in a unit of a Dutch bank in the northeast of the Netherlands. The project, involving the development, implementation and use of a digital information system, combined with a workflow management system, started in July 1995 and ended in March 1997. The structure of this chapter is as follows: section 4.2 describes the organizational context of the project, followed by section 4.3 which presents the project description in terms of our research model. Then, in section 4.4, we test our three hypotheses and finally, in section 4.5 we reflect on our findings.

\subsection{The organizational context}

A digital information system combined with a workflow management system (from now on referred to as DIS) has been implemented in a unit of a Dutch bank, based in the northeast of the Netherlands. This bank is part of a large organization, in fact it is the $5^{\text {th }}$ financial concern in the Netherlands, following mergers, with a net profit of $€ 116$ million (257 million Dutch Guilders, 1997) and around 5000 employees. Notably, the bank had put an emphasis on the growth of their insurance activities in the mid 1990s, because the margins in traditional banking activities had decreased, and new sources of income were required. Trying to increase its market share of the growing insurance business was considered as one way to at least maintain turnover. This has been a successful strategy.

The bank created one central department, which we will refer to as unit $A$, where all the data processing activities concerning insurance take place, a socalled "back office". Initially, unit A started with around 20 employees, but this had grow to around 65 employees by 1990x. It is this unit A that forms the organizational context of the office technology project discussed in this chapter.

The typification of the office

In terms of the taxonomy of chapter 1 , the office in our unit of study can be typified as a procedural office. At the operational level, unit A consists of groups of individuals (which can be labeled as departments) that operate PCs in order to process information. The primary process of unit $A$ is to process requests for 
insurance policies that come from local bank offices, or from intermediaries. Unit A also processes claim settlements for clients. Overall, employees at the operational level carry out sets of explicit steps towards a specified end, thus meeting the terms of a procedural office.

\section{Characteristics of the employees}

The employees of Unit A could be characterized as follows (based upon a response rate of $67.7 \%$ to the questionnaires): $43.2 \%$ were male, $56.8 \%$ female; the average age was 31.9 ; the average time working at the bank was 7.5 years; the education level of $75 \%$ of the employees is high school (HAVO, VWO, MBO).

\subsection{The project "Verdi"}

\subsubsection{Methodology}

To investigate project "Verdi" we used conversational interviews, documents, observations, and questionnaires. The conversational interviews were held with: the board member responsible for IT matters, the current general manager, the previous general manager, the project manager, the current incompany IT project manager (who had a managerial job at the time of the project), one managerial employee, an IT consultant from the IT supplier, and four non-managerial employees. In addition we studied documents, such as plans of approach, and observed the system while used by employees. Finally, we asked the employees who used the system to complete questionnaires.

In the remainder of this chapter the terms employees and users are interchangeable.

\subsubsection{Project characteristics}

The idea of implementing a DIS arose in a period when unit $A$ was much smaller than it had become, with only around 20 employees. Although the creation of one central back office was seen as advantageous because of efficiency gains; bank mergers had also brought about a number of problems. The most relevant were the different ways of processing, administrating, and archiving data that existed.

These problems, and the expectation that the level of insurance activities would increase quite extensively in the next few years, and so require extra space for archiving physical documents, were reasons for unit A's management team (of which the general manager was a member) to formulate a proposal to implement a digital archiving system. It was believed to be the best available solution at that time. The board of directors approved the proposal in February 1995. From that moment on, the process of developing a new system started. 
This proposal concerned the implementation of just a digital information system, not a workflow management system. Because none of the members of the management team were experienced with managing large IT projects, an extend consultant was appointed as project manager. He proposed a digital information system in combination with a workflow management system, which was a very new concept in the Netherlands at that time. The possibilities of this combination exceeded the management team's initial functional demands.

After deciding to opt for a digital information system with a workflow management system, and selecting a vendor organization which we will call company $B$, the management team of unit $A$ set up a project organization to begin the development and implementation of the new system. This new system was named DIS (an abbreviation from digital information system).

In July 1995 the Verdi project officially started. The project organization consisted of a steering committee, a project manager and a project team. The steering committee consisted of the whole management team of unit $A$, the consultant who was appointed as project manager, and two representatives from the bank to which unit $A$ belongs. The project team had six members, the project manager, the in-house IT manager, an IT consultant from company B., two managerial employees, and one non-managerial employee. In terms of the duration of the project, the plan assumed that it would last for about 6 months, thus ending around December 1995. In reality the project ended in March 1997, a delay of 15 months.

Before the definitive roll out of the DIS, the work place was first redesigned. New PCs and larger screens were installed, desks and chairs were renewed. New PCs were necessary to meet hardware demands. New screens, desks and chairs were needed following an investigation of the work place by an $\mathrm{ARBO}^{7}$-service, which produced recommendations for optimizing the work place. Approximately six months after the implementation of the DIS, users were working with the DIS in a more or less stable way.

Table 4.1 presents the characteristics of the "Verdi" project from an office technology development and implementation methodological point of view.

${ }^{7} \mathrm{ARBO}=$ abbreviation from Dutch: Arbeidsomstandigheden, which means labour conditions. 


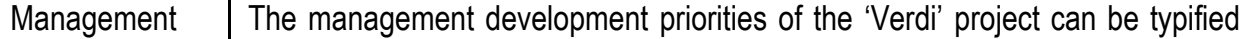
development priorities $=$ as being dominated by technical optimization. The project started from the technical optimization drive to optimize the current manual 'system' as this was seen to be problematic (large archives, lost physical files, much physical activity, and an expected growth of the amount of work in the near future). Work and social system optimization also played a role, in the sense that the management believed that, with a new office technology, the processes would lead to less frustration regarding lost files etc. This, however, was not the main reason.

Extent of user Users (actually a small group representing the rest) at the operational level participation $=$ moderate were involved, especially when the requirements of the new systems had to be mapped. Users were thus involved to provide information about the current work processes, and to a certain extent they had a say in the way the future work processes should be organized. In addition, users were particularly involved in the test stage, to check whether the new system functioned technically as expected.

\begin{tabular}{|l|l|}
\hline $\begin{array}{l}\text { Approach to } \\
\text { problem inves- } \\
\text { tigation = } \\
\text { Top down }\end{array}$ & $\begin{array}{l}\text { In the 'Verdi' project it was especially the management, and very much the } \\
\text { head of Unit A, who defined the problem and sought a solution for his defini- } \\
\text { tion of the problem. }\end{array}$ \\
\hline $\begin{array}{l}\text { Approach to } \\
\text { system model- } \\
\text { ling = pre- } \\
\text { dominantly } \\
\text { function ori- } \\
\text { ented }\end{array}$ & $\begin{array}{l}\text { The requirements were mapped by the project manager and the heads of the } \\
\text { separate departments, who formed task forces in which some users at the } \\
\text { operational level participated. This resulted in system requirements that were } \\
\text { not only function-oriented, but to some extent also work-process oriented. The } \\
\text { management wanted a system that improved the current way of working by } \\
\text { implementing a new technology, not by changing the current way of organizing } \\
\text { the work processes. Therefore the new office technology should have a few } \\
\text { specific functions: storage and retrieval of files, and the routing of files. Map- } \\
\text { ping of the work processes occurred predominantly in terms of a set of ab- } \\
\text { stract process steps, which were not related to tasks of individuals. }\end{array}$ \\
\hline $\begin{array}{l}\text { Control of de- } \\
\text { velopment } \\
\text { process = } \\
\text { predominantly } \\
\text { formal and } \\
\text { structured }\end{array}$ & $\begin{array}{l}\text { Management control in the 'Verdi' project was exerted in a formal and struc- } \\
\text { tured way. Documents played a dominant role in the project. The project was } \\
\text { divided into stages that each had to result in a document. Technical develop- } \\
\text { ers did not have immediate contact with users. }\end{array}$ \\
\hline $\begin{array}{l}\text { Project life } \\
\text { cycle time } \\
\text { scale = long }\end{array}$ & $\begin{array}{l}\text { The 'Verdi' project was divided into a pilot stage and a final roll out stage, } \\
\text { which reflects a short life cycle time scale. However, the pilot stage did not } \\
\text { involve the testing of separate parts of the final new office technology, but } \\
\text { rather the new technology as a whole. The pilot was only intended to test the } \\
\text { new technology for specific types of files. Therefore, we conclude that the new } \\
\text { technology was in fact implemented with a 'big bang' scenario, by which is } \\
\text { meant that a new technology is offered to all users at once. }\end{array}$ \\
\hline
\end{tabular}

Table 4.1 The characteristics of the 'Verdi' project (continued on the next page) 

which reflects a 'waterfall' project life cycle model. However, it did contain an evolutionary element, namely a pilot involving only a part of the work process. But this pilot of the new system was also implemented as a whole, and not in separate parts. This again reflects a 'waterfall' model.

\section{Table 4.1 The characteristics of the 'Verdi' project}

From the description of the project characteristics we draw the conclusion that overall, the office technology development approach can be typified as predominantly hard.

We now elaborate on the contribution of the management and the IT experts involved in this project.

\section{Management contribution}

Unit A's general manager was the project initiator. He recognized that the bank mergers had brought about a chaotic situation in processing and archiving files. In his view, archiving could be done more efficiently and take up less space. The general manager emphasized looking for a technological solution. He developed a proposal, which needed approval by the board of directors in order to receive a budget. The board particularly stressed the need for increased efficiency and reduced costs.

The project's steering committee carried the final responsibility. The committee stressed that the DIS had to increase efficiency, improve the quality of the service level, and reduce the costs of labor, archiving, and copying. However, the committee also was a supporter of involving users in the project, and consulting with an ergonomic expert to assess whether the work situation with the DIS was ergonomically acceptable. Furthermore, the steering committee decided not to change the current organizational design. The project manager did not really agree with this decision because unit A's organizational design had predominantly Tayloristic characteristics, which was not the project manager's preference. The project manager believed it was necessary to involve users, as he believed that one could not implement workflow management systems without users who supported it.

In conclusion, in the "Verdi" project the management's main contribution was as advocates of performance issues, but they did consider organizational, environmental, and human issues to a limited extent.

\section{IT experts' contribution}

In the "Verdi" project there were two categories of IT experts, one from company $B$, the IT company, and one from unit $A$. These parties collaborated 
during the project, but not without some problems. Company $B$ initially only provided standardized components of the DIS to unit A. Later in the project this was recognized, when it became clear during a first pilot that the DIS performed very poorly. The IT experts especially stressed the advantages of a DIS regarding the performance of the organization, and were predominantly technically oriented. In their view, implementing a DIS, if technically sound, would lead to the expected advantages. This is reflected by the fact that company $B$ only sold standard components to unit A., and also by the fact that the IT experts did not propose changes in the internal organizational environment, or pay attention to the human issues such as working conditions.

The IT experts from unit A were also predominantly oriented towards preparing a technically sound DIS, without taking into account the deeper internal organizational environment, or issues concerning working conditions. However, these experts were quite close to the users since unit $A$ was a small organization and therefore the interpersonal relationships were relative informal and familiar. This meant that most users trusted them.

In conclusion, the IT experts main contribution was as technicians who stressed the contribution of a DIS to the performance of the organization. They failed to bring in organizational, environmental, and human issues.

\subsubsection{User involvement}

In Table 4.1 we saw that employees/users were only involved to a moderate extent. To answer the question more specifically as to how users were involved we can use the framework presented in chapter 3.

\begin{tabular}{|l|l|l|l|l|l|l|l|l|}
\hline Stage of the Verdi project & $\mathbf{2}$ & $\mathbf{3}$ & $\mathbf{4}$ & $\mathbf{5}$ & $\mathbf{6}$ \\
\hline Initial decision making & $\mathrm{X}$ & & & & & \\
\hline Requirements analysis & & & & $\mathrm{x}$ & & \\
\hline Functional design/Technical design & & & $\mathrm{X}$ & & & \\
\hline Technical realization & & & $\mathrm{x}$ & & & \\
\hline Testing/pilot & & & $\mathrm{x}$ & & & \\
\hline Roll out & & $\mathrm{x}$ & & & & \\
\hline
\end{tabular}

$1=$ no or minimal information, 2 = information, $3=$ opportunity to give advice, 4 = advice taken into consideration, 5 = joint decision making, 6 complete control.

Table 4.2 User involvement at each development stage of the DIS 
Table 4.2 shows that employees/users were involved to the largest extent in the requirement analysis stage. They were hardly involved at all in the initial decision making process. In the functional/technical design stage, the technical realization stage, and the test/pilot stage, users were moderately involved, but it is important to note that this was realized through the one user who was a member of the project team. Thus not all the users individually were involved.

\subsubsection{The clarity of the spirit}

The spirit of the DIS when it was fully rolled out throughout unit $A$ can be characterized as: control to increase efficiency and performance, to reduce costs and to create a paperless work process. In figure 4.1 below this spirit is visualized and 'deconstructed' into some of its main structures. 


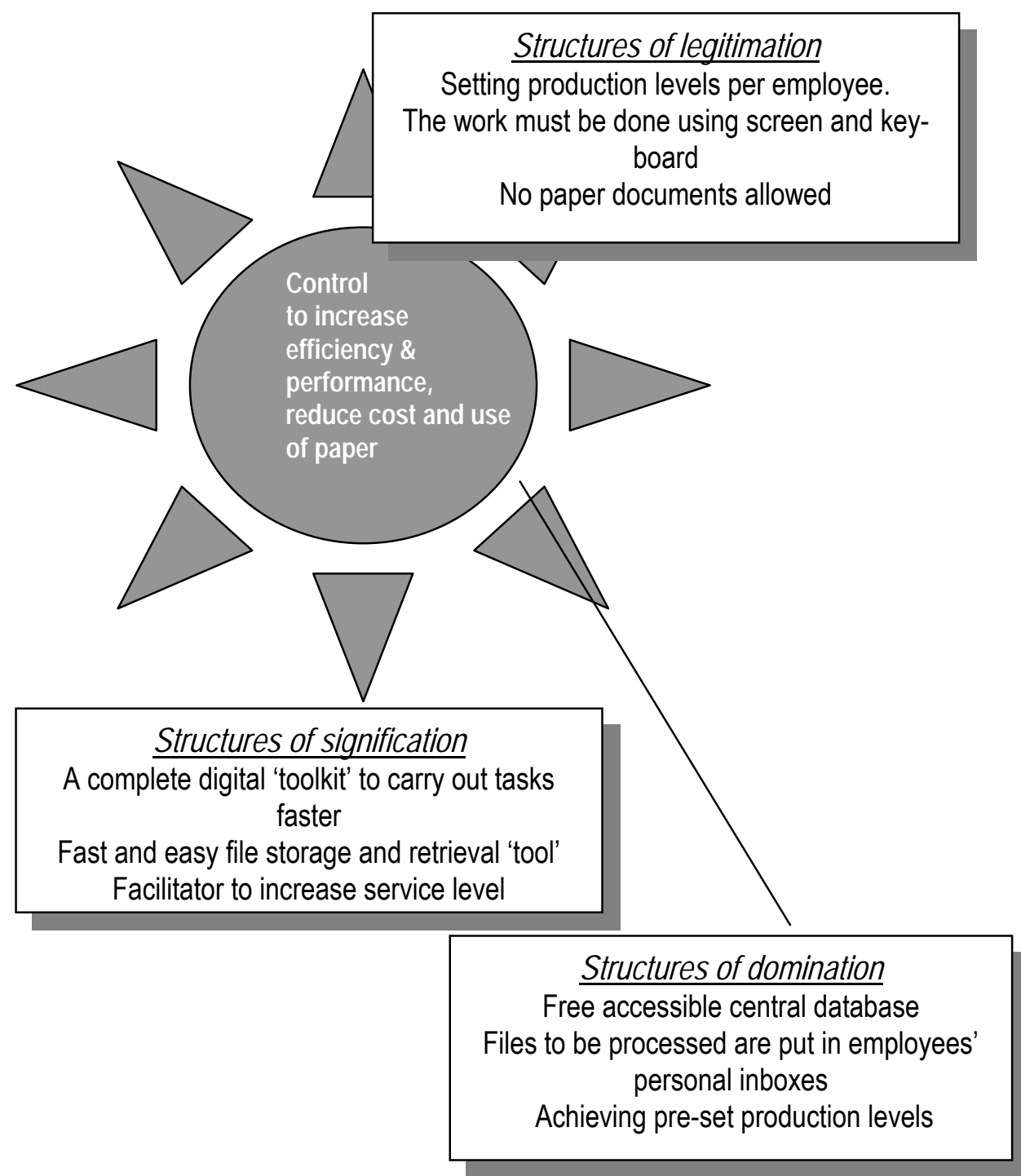

Figure 4.1 The spirit of DIS in the initial development stage 'deconstructed' into examples of its main structures.

Figure 4.1 reflects how the DIS' spirit can be described. The underlying philosophy of the DIS (an alternative description of the concept of spirit) was to achieve more control of the primary process (the diverse ways of processing, administrating, and archiving, together with the low level of service were experienced as problematic). It was believed that technology could provide this control. By attaining more control, efficiency was expected to increase, as well as the performance of unit $A$ as a whole. Furthermore, costs and the use of paper should be reduced. 
This spirit can be deconstructed into structures, which users ought to draw on and appropriate. This however might not occur if users find the spirit unclear (assuming that the technical features are technically sound).

The technical features of the DIS, in order to realize the system's spirit, can be typified as follows:

\begin{tabular}{|l|l|l|}
\hline $\begin{array}{l}\text { Criteria } \\
\text { Level of re- } \\
\text { strictiveness }\end{array}$ & $\begin{array}{l}\text { Description } \\
\text { The DIS leaves the user a limited set of possible ac- } \\
\text { that allows only the same actions over and over again". }\end{array}$ & High \\
\hline $\begin{array}{l}\text { Level of so- } \\
\text { phistication }\end{array}$ & $\begin{array}{l}\text { The DIS provides complete data storage support as it is } \\
\text { a complete archiving system; and also data manage- } \\
\text { ment support, as it includes a work flow management } \\
\text { system. It provides communication support to only a }\end{array}$ & Moderate \\
$\begin{array}{l}\text { limited extent; users can interact by sending messages } \\
\text { to each other in order pass information, for example, } \\
\text { about how to deal with a certain case. The system does } \\
\text { not offer users highly sophisticated tools with which to } \\
\text { interact. }\end{array}$ & $\begin{array}{l}\text { The DIS contains quite a number and variety of features } \\
\text { that are supportive to users in their day-to-day activities. } \\
\text { The DIS is able to digitalize paper documents, to guide } \\
\text { documents through the organization, to manage (create } \\
\text { and/or modify) documents, and to archive. It does not } \\
\text { contain facilities to send or receive documents through } \\
\text { the internet. }\end{array}$ & Moderate \\
\hline $\begin{array}{l}\text { Degree of } \\
\text { comprehen- } \\
\text { siveness }\end{array}$ & & \\
\hline
\end{tabular}

\section{Table 4.3 Typification of the DIS' technical features}

The spirit of the DIS was not very clear to users when it was first offered to them. In unit A, the first weeks were very confusing. Partly because users could not appropriate the system due to many technical problems, partly because the potential of structures (the spirit together with the technical features) of the DIS was unfamiliar to them. Thus during the first weeks, users were not able to appropriate the DIS in line with its spirit. Users did not know what structures to bring in action or if they did how to bring them into action.

\subsubsection{Appropriation of the DIS}

The first weeks after the complete "roll out" of the DIS were confusing; a lot of things failed completely. At first, not all the employees could really "see through" the new system. For example, some of them did not understand how a file went from one place to another, and some of the employees found it hard to accept that the letter they had written was printed out on another floor and from 
there was sent to third parties or to clients by colleagues. The author of the letter did not get to see the "physical" version of the letter after it left the screen. It was a matter of trust, as it was no longer necessary to add a personal signature to a letter. After finishing a letter, employees, from now on, had to rely on the system to put the letter in the right file. Other problems that arose were that files got "lost" in the system because users forgot how the coding of files functioned, users forgot to couple letters with files, and there were still frequent system breakdowns.

It took a few weeks before the work process with the DIS went reasonably smoothly. As noted, most importantly, employees had to learn to rely on the DIS. However, it was quite a change for most of them to work with a keyboard and a screen all day, especially for those who were very inexperienced with computers. Before the DIS was introduced, employees felt and saw physical documents. Employees made notes on them, filled in certain parts, etc. They also had to walk around the office to make copies, to find documents in the archive, to consult colleagues with specific questions about a document, and so on. These activities were experienced as important opportunities for employees to have some informal intercations with colleagues. After the DIS was implemented, in fact, employees could sit behind their screen and keyboard all day, and still do their work. This was seen as an important change for employees in Unit A. An ARBO service organization had already advised on optimizing ergonomic aspects, and its recommendations were adopted. But in terms of finding channels for informal talks and breaks, initially no plans were developed. The employees who smoked found a solution by using their usual smoke-breaks for informal talks, but employees who did not smoke had few reasons to leave the work place. The management agreed to allow all employees to have short breaks.

One of the problems experienced at unit A before the DIS was offered to users, was that the merger partners used different types of work procedures. For efficiency, the management tried to "converge" towards one procedure. With the DIS (a combination of a digital archiving system and workflow management) they tried to 'force' employees to follow a common procedure, or as the team coordinator of the Claim Settlement unit put it:

"Actually it is a system that can be used in one way only, so employees cannot use it differently. The system does not offer that possibility".

The discussion arose about whether working with the DIS should be considered as short-cycle work. According to the ergonomic expert this was not the case as employees had possibilities to vary the day-to-day work such as leaving the work place to making copies, or making phone calls.

Strikingly, despite part of the spirit of the DIS being to create a paperless office, it was found that this could not be realized within the first weeks of DIS 
use. A certain percentage of the files were judged as being too complicated to process with the DIS (the so-called "difficult cases") and therefore had to be processed manually. This still required copying activities and consultations of colleagues.

Around six months after the implementation of the DIS, the situation in unit A stabilized. Employees seemed to have "incorporated" the DIS into their day-today activities to a reasonable extent. The technical problems, such as the insufficient hardware capacity, were solved to a certain extent. The stage of ongoing use had effectively started. In Table 4.4 below, the way users appropriated the DIS in this ongoing use stage is described for each dimension.

\begin{tabular}{|c|c|}
\hline $\begin{array}{c}\text { Aspect of ap- } \\
\text { propriation }\end{array}$ & Description \\
\hline $\begin{array}{l}\text { Appropriation } \\
\text { moves = high }\end{array}$ & $\begin{array}{l}\text { In the ongoing use stage the level of appropriation moves by users was } \\
\text { high. This is not surprising as the DIS had to function as a full toolkit, and it } \\
\text { was the users' main means of carrying out the in day-to-day tasks. }\end{array}$ \\
\hline $\begin{array}{l}\text { Faithfulness of } \\
\text { appropriation }= \\
\text { moderate }\end{array}$ & $\begin{array}{l}\text { In the ongoing use stage users appropriated the DIS to a moderate extent } \\
\text { in accordance with its spirit. The DIS brought users to digitalize an exten- } \\
\text { sive part of the paperwork (e.g. write digital letters, to archive electronically, } \\
\text { and so on.) But the work process did not become completely paperless, as } \\
\text { some of the policies could not be processed by the DIS, and to a certain } \\
\text { extent users continued to print out documents. } \\
\text { The efficiency of the work process had increased because insurance poli- } \\
\text { cies could now be stored easier, but processing a request for an insurance } \\
\text { policy took longer than expected and initially hoped. Users found that they } \\
\text { could only process two or three policies per hour, while it had been ex- } \\
\text { pected that users could do around ten per hour. Hence, in the ongoing use } \\
\text { stage a huge backlog developed. Thus, users experienced doubts about } \\
\text { the extent to which they were able to realize an increase in efficiency by } \\
\text { appropriating the DIS. }\end{array}$ \\
\hline $\begin{array}{l}\text { Attitude towards } \\
\text { the DIS (per- } \\
\text { ceived useful- } \\
\text { ness) = } \\
\text { high }\end{array}$ & $\begin{array}{l}\text { The DIS was experienced as useful for the day-to-day tasks. This is not so } \\
\text { strange since the DIS was the main means to carry out their work. On the } \\
\text { other hand, users also experienced that the DIS did not meet all their re- } \\
\text { quirements. For example, the DIS aimed to reduce paperwork to almost } \\
\text { 'zero', but this did not occur as users still made print-outs of their work, and } \\
\text { some of the work could be dealt with electronically since it needed a more } \\
\text { elaborate treatment. }\end{array}$ \\
\hline $\begin{array}{l}\text { Attitude towards } \\
\text { the DIS (perceive } \\
\text { ease of use) }= \\
\text { moderate }\end{array}$ & $\begin{array}{l}\text { The DIS in the ongoing use stage was still quite complicated to appropri- } \\
\text { ate, partly because of the continuous technical problems. For some users } \\
\text { it was still hard to appropriate the DIS. }\end{array}$ \\
\hline
\end{tabular}

Table 4.4 Users' appropriation of the DIS in the ongoing use stage (continued on next page) 


\begin{tabular}{|c|c|}
\hline $\begin{array}{l}\text { Aspect of ap- } \\
\text { propriation }\end{array}$ & Description \\
\hline $\begin{array}{l}\text { Task oriented use } \\
=\text { high }\end{array}$ & $\begin{array}{l}\text { In the ongoing use stage, the DIS was appropriated as highly task- } \\
\text { oriented. This is not surprising, as the spirit of the DIS did not encourage } \\
\text { users for other types of appropriation. The DIS spirit did not focus, for ex- } \\
\text { ample, on personal use of the DIS, and neither did it invite users to appro- } \\
\text { priate the DIS in other ways than for the day-to-day task. }\end{array}$ \\
\hline $\begin{array}{l}\text { Explorative use = } \\
\text { low }\end{array}$ & $\begin{array}{l}\text { Users were still finding out how the DIS should be appropriated, but the } \\
\text { level of explorative use has decreased since users had started to appropri- } \\
\text { ate the DIS. }\end{array}$ \\
\hline $\begin{array}{l}\text { Consensus } \\
\text { among users on } \\
\text { appropriation = } \\
\text { moderate }\end{array}$ & $\begin{array}{l}\text { Although the DIS did not leave much space for a broad range of different } \\
\text { styles of appropriation, users have experienced differences. Of course, } \\
\text { some users were appropriating the DIS for claim settlement, others for } \\
\text { policy acceptance. But besides this, some users would print out some parts } \\
\text { of their work, while others did not. Some users kept files in their inbox for } \\
\text { the period they thought they would need them. Others, put files back in the } \\
\text { central database immediately after they have carried out the necessary } \\
\text { work, so that they were available again for other users. In conclusion, al- } \\
\text { though restrictive, the DIS does leave room for personal styles of appro- } \\
\text { priation. }\end{array}$ \\
\hline
\end{tabular}

\section{Table 4.4 Users' appropriation of the DIS in the ongoing use stage}

From Table 4.4 we can conclude that, in the ongoing use stage, users did appropriate the DIS to quite a high extent. The levels of appropriation moves, perceived usefulness, and task-oriented use were especially high. However, to an extent, this is due to the fact that the DIS is a necessary tool. The levels of faithful appropriation, perceived ease of use, and consensus on appropriation are moderate, indicating that appropriation of the DIS is not without problems.

\subsubsection{The context of DIS appropriation}

The "Verdi" project was characterized by the following contextual factors (Table 4.5). 


\begin{tabular}{|l|l|}
\hline \multicolumn{1}{l}{ Characteristic } \\
\begin{tabular}{|l|l|} 
Level of change in internal organi- \\
the \\
zation
\end{tabular} & $\begin{array}{l}\text { The management did not intend to change the basic organizational } \\
\text { design with the Verdi project. But, as the DIS implementation meant } \\
\text { large differences in the way of carrying out tasks compared with the old } \\
\text { situation, users in general experienced significant changes, especially } \\
\text { of a physical nature. In general the content of the jobs did not change } \\
\text { very much, but the experienced work environment changed, because } \\
\text { after implementation the offices were full of screens and keyboards. }\end{array}$ \\
\hline $\begin{array}{l}\text { Level of work auton- } \\
\text { omy after the im- } \\
\text { plementation }\end{array}$ & $\begin{array}{l}\text { Jobs at the operational level at Unit A had a short-cyclical nature be- } \\
\text { fore the implementation of the new system. Atter the implementation } \\
\text { this did not reduce, as a matter of fact they even became a little more } \\
\text { short-cyclical. Before implementation the culture within Unit A was } \\
\text { quite informal, with less immediate management control. After the im- } \\
\text { plementation, management control increased because the new system } \\
\text { contained instruments to monitor the work processes. }\end{array}$ \\
\hline $\begin{array}{l}\text { Satisfaction with } \\
\text { implementation pro- } \\
\text { cess }\end{array}$ & $\begin{array}{l}\text { Users received little training before implementation, they had to 'learn } \\
\text { by doing'. Furthermore, because of the extensive technical problems } \\
\text { with the DIS, users in general experienced the implementation as prob- } \\
\text { lematic. }\end{array}$ \\
\hline $\begin{array}{l}\text { Satisfaction about } \\
\text { reason for new sys- } \\
\text { tem development }\end{array}$ & $\begin{array}{l}\text { Users initially were skeptical about the plan to develop a new system, } \\
\text { but also passive. They waited to see what the result would be. Users in } \\
\text { general seemed to agree that solutions had to be found for the increas- } \\
\text { ing number of files that had to be physically stored. }\end{array}$ \\
\hline $\begin{array}{l}\text { Satisfaction about } \\
\text { support when having } \\
\text { pngoing use stage }\end{array}$ & $\begin{array}{l}\text { In the ongoing use stage, the DIS still had technical problems and } \\
\text { therefore users needed help. However, within Unit A, there was only } \\
\text { one DIS expert available in the ongoing use stage. Therefore, technical } \\
\text { DIS expertise was scarce, and users experienced this as such. }\end{array}$ \\
\hline
\end{tabular}

Table 4.5 "Verdi" project contextual characteristics

Users experienced a moderate level of change in their work environment, and a moderate level of work autonomy in their work after the implementation of the DIS. They were moderately to highly positive about the reasons for developing the DIS, but much less positive about the implementation process. Users' satisfaction with the support level when having problems with the DIS was moderate.

\subsubsection{Project outcomes}

Table 4.5 shows the outcomes of the Verdi-project: 
Work process In the ongoing use stage, the opinions in unit A about the effects of the DIS effectiveness $\quad$ are not unequivocal. Some said that the goals of the Verdi project had been = moderate achieved, others questioned this. We observed that, at least in some senses, goals were achieved, for example with regard to file retrieval and archiving. In spite of the problems experienced, file retrieval had become easier and faster (previously employees had to find a file from among the 50 others that were on their desk), and archiving does now take up very little space because files are stored on videodisc (in former days physical files were stored in cupboard). But it is questionable whether work processes are faster with the DIS than before, and whether the number of mistakes (quality aspect) have decreased, or costs been reduced.

\begin{tabular}{l|l} 
Unanticipated & The introduction of the DIS led to quite a number of unanticipated changes
\end{tabular} changes $\quad$ within Unit A. We give three prominent examples. Firstly, it was not antici= high $\quad$ pated that, within the unit a whole new subunit would have to be created, a subunit that scans the incoming mail.

Another unanticipated change was that employees/users looked for new reasons for physical movement. The DIS allows them to sit for eight hours a day behind a screen and keyboard and still do the job. This contrasted with the "old days", when users were used to moving during the day, to walk to the archives. One of the new rules is that all users are allowed to moving around from their workplaces every two hours for around 15 minutes. This is not interpreted too strictly, but it appeared to be necessary to make a rule for this.

A third and final unanticipated change was that after the introduction of the DIS it appeared to be necessary to process some files by hand (claim settlements, insurance requests) that were too complex to handle electronically. This was not foreseen, and it led to the situation that managers had to think about how to manage this: should every employee handle a few complex files or should only a few employees handle all of them?

Anticipated $\quad$ We already noticed that the spirit of the DIS in the initial development stage changes $=\quad$ was ambitious and quite optimistic. Initially, the structures promoted by this high $\quad$ spirit resulted in significant friction with the usual behavior. In other words, the introduction of the DIS was expected to bring about extensive changes. Generally speaking, the DIS brought about a whole new way of doing the day-to-day tasks: from paper-based work to digital work.

Project costs $=$ The exact project costs are not available, but it is clear that the project team budget far ex- had to ask for extra budget more than once. The project exceeded by far its ceeded initial budgets. Estimated costs: 1.5 to 2 million Dutch Guilders

\section{Table 4.5 Project outcomes}

This completes the descriptive part of the "Verdi" project analysis. In the next section, the relationships between the main variables in our research model are tested. 


\subsection{Testing the hypotheses}

\subsubsection{Hypothesis 1}

Having completed descriptive part of the office technology project in unit $A$ we are now in a position to test our three basic hypotheses. Only the three basic hypotheses will be tested for each individual case, the additional hypotheses will be tested in the cross-case analysis in chapter 8.

First of all, hypothesis 1 :

The extent to which users have a say in the development and implementation of office technology is positively related to the clarity of the spirit to users.

As discussed in chapter 3 , we used a questionnaire to determine the extent to which users had a say in the development and implementation of the DIS, and the extent to which they found the system's spirit clear. The analysis of their answers resulted in the following statistical relationships.

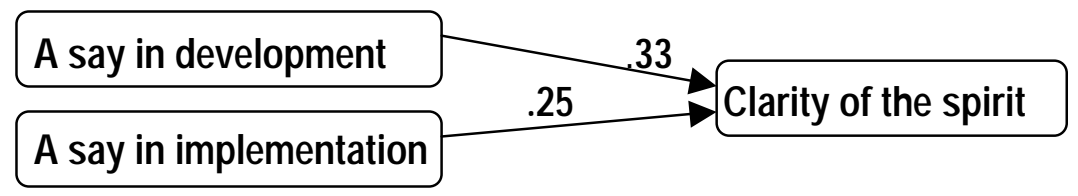

Figure 4.2 The relationship between having a say in the development and implementation, and the clarity of spirit $(\mathrm{N}=44)$

We noted that, in unit $A$, users in general had a moderate influence on the development and implementation of the DIS. The results shown Figure 4.2 indicate that users who were involved in the development or the implementation have a clearer picture of the DIS's spirit than users who were not, although the relationship is not statistically that significant. Nevertheless, we can consider that our hypothesis was confirmed.

It is curious that the relationship is not very strong. We think that, in unit A, this weak positive relationship is due to the fact that the implementation of the DIS took a considerable time. Because of all the technical problems it took a long time before the new system could be fully rolled out. Employees in the meantime could get acquainted with the new system, since they were informed about new delays, etc. They could also take a look at the system during the pilot stage and talk to other employees who were involved in these tests. Therefore, there were several ways over a significant period of time in which employees who were not immediately involved in development and implementation could gain knowledge about the new system, and thus about its spirit. 


\subsubsection{Hypothesis 2}

The second hypothesis is:

The clarity of the spirit to users is positively related to the level of appropriation.

An analysis of the questionnaire responses led to the following results:

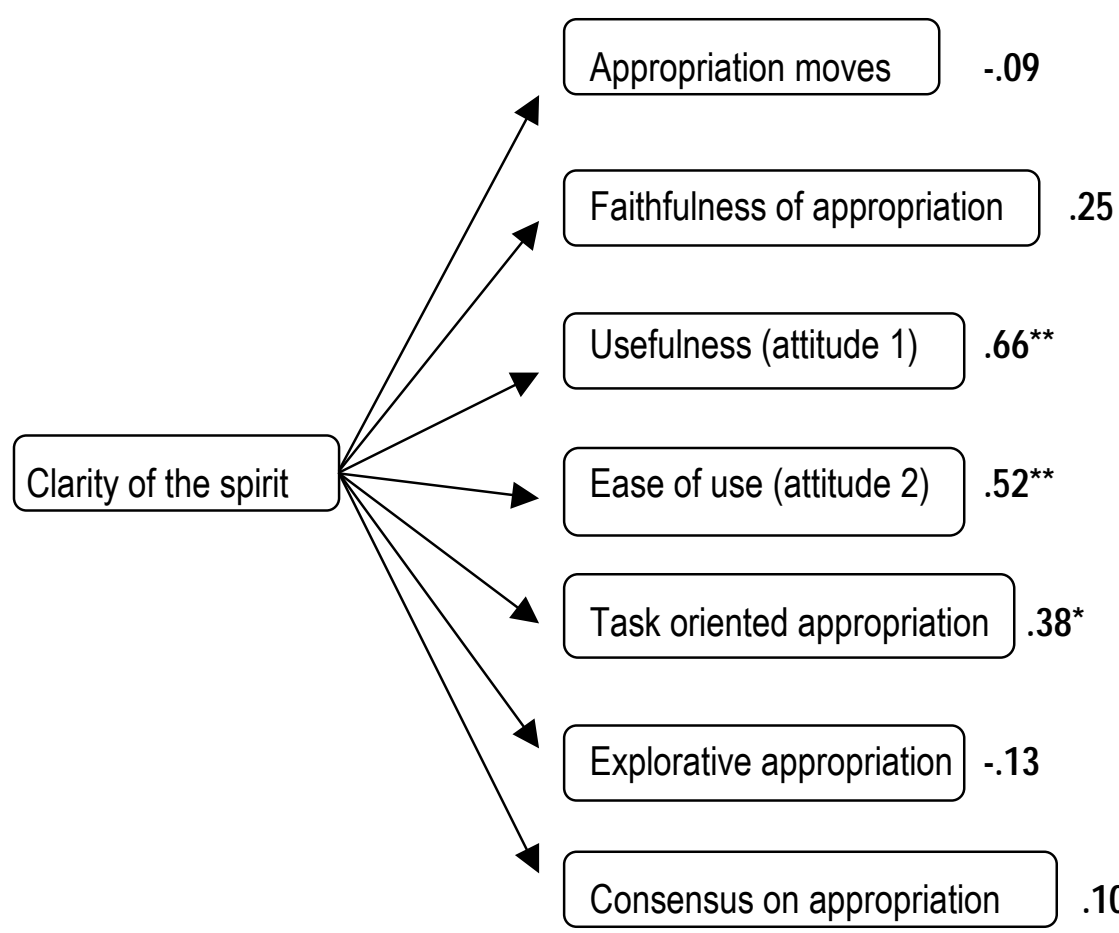

${ }^{*}=p<0.05 ;{ }^{* *}=p<0.01$

Figure 4.3 The relationship between the clarity of the spirit and the level of appropriation ( $\mathrm{N}=44)$

From the results from unit $A$, as presented in Figure 4.3, we can say that the clearer the spirit is to users, the higher the extent of faithful appropriation, perceived usefulness, perceived ease of use, and task oriented use. The clarity of the spirit is not, or only weakly, related to the level of appropriation moves and consensus on appropriation. One further finding is that, the clearer the spirit is to users, the less explorative work they do. 
That the clarity of spirit does not relate to the level of appropriation moves is theoretically unexpected, but can be explained from the 'unique' situation in unit A. In general, in unit A, users had no alternative but to use the DIS for their work. Whether they found the system's spirit clear or not, they had to use the DIS. Therefore a strong positive relationship should not have been anticipated.

The results show that users of the DIS who find the system's spirit clear, appropriate the DIS more faithfully (although not statistically significantly), perceive the DIS as more useful and easier to use, and appropriate its more taskoriented structures more than those who find the spirit less unclear. This is in line with theoretical expectations. However, it is surprising that the relationship between the clarity of the spirit and faithful appropriation is somewhat weak. We think that this can be explained from the observation that the DIS was still suffering considerable technical problems. This could make it hard for users to appropriate the DIS in line with its spirit, even though they find the spirit clear.

That the clarity of spirit is only very weakly positively related to the level of consensus on appropriation is also explainable from the technical problems with the DIS. It is plausible that this can make it hard for users to develop a consensus on working with the system.

Overall, with regard to our second hypothesis, we conclude that it has been confirmed.

\subsubsection{Hypothesis 3}

Our third hypothesis is:

The level of office technology appropriation is positively related to the level of work process effectiveness. 
From the questionnaire we obtained the following results:

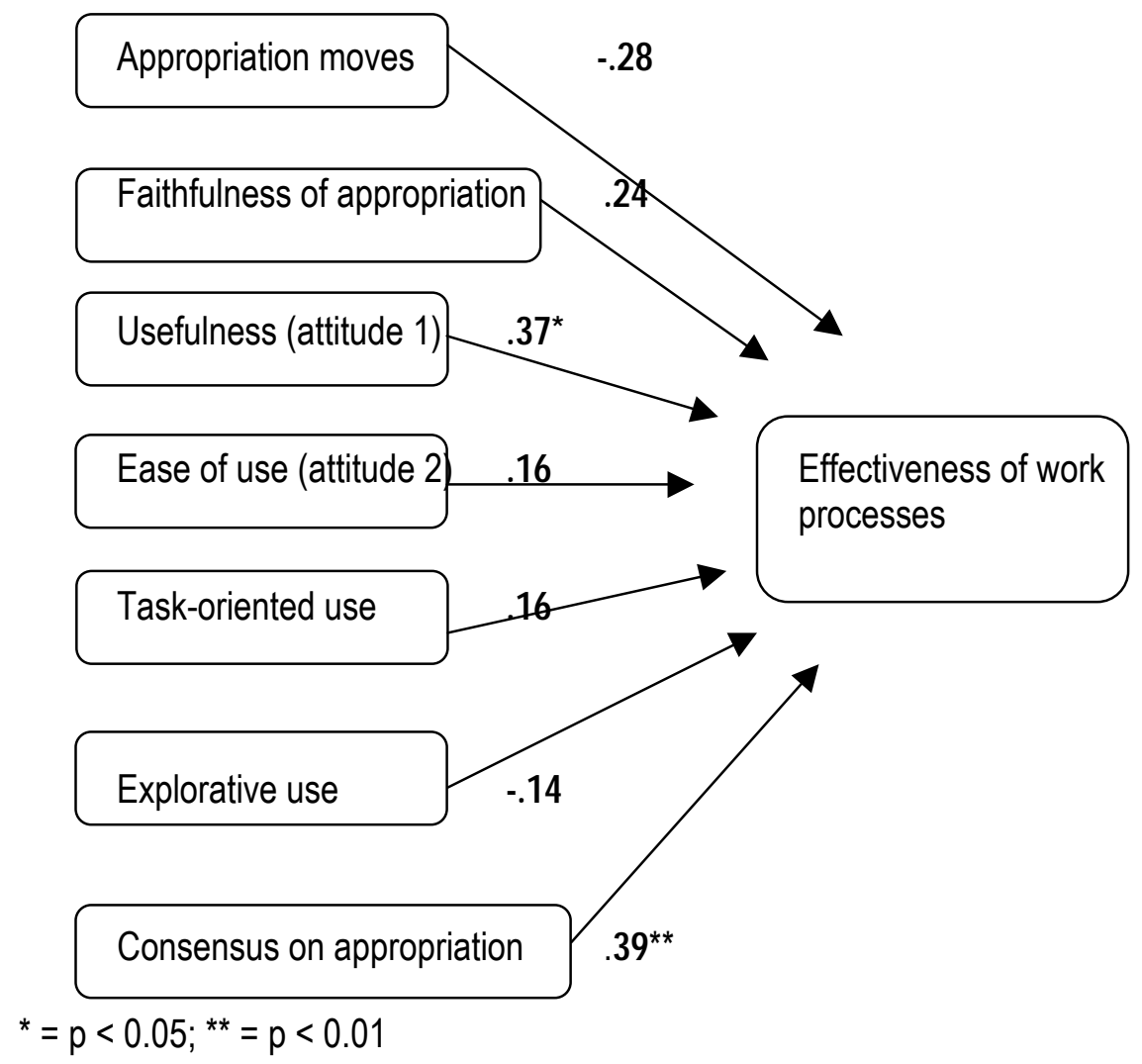

Figure 4.4 The relationship between appropriation and work process effectiveness

We observe that, in particular, the level of faithful appropriation of the DIS, perceived usefulness of the DIS, and the level of consensus on appropriation are positively related to work process effectiveness. This is in line with our theoretical expectations. It means that users who work in line with the spirit of the DIS, perceive the DIS as useful, experience a consensus on how to work with the DIS, and judge the work processes to be effective.

That the level of appropriation moves correlates weakly and negatively with the effectiveness of work processes indicates that simply working with the system (making appropriation moves) does not make a difference to work process effectiveness. It needs more than just the moves in order to add to work process effectiveness. 
That the aspects of appropriation concerning perceived ease of use and task-oriented use are only sightly positively related to work process effectiveness is theoretically unexpected. Our research model takes into account two possible explanatory factors: the level of organizational change, and the level of work autonomy. In this case especially the level of organizational change can explain this unexpected outcome. From the project description we learned that the Verdi project did not include any real change in the organization of the work processes. It is probable that the DIS would have contributed to work process effectiveness, if the work process itself had also been re-organized.

Overall we observe that in general the correlations are not very strong, which indicates that, so far, the introduction of the DIS has not been a good solution for improving work process effectiveness. Thus, in conclusion, the third hypothesis is not confirmed.

Having tested the three hypotheses, we can summarize that it was confirmed that users who are more involved during a project have a clearer image of the DIS's spirit, and that the more users who find the DIS's spirit clear, the higher their level of appropriation of the DIS. It was not confirmed that the level of appropriation is positively related to work process effectiveness. We think that this can be explained by the fact that the DIS still had problems, and that the Verdi project did not involve a planned re-organization of the work process alongside with the implementation of the DIS.

\subsection{Summary of findings}

The office technology project in unit A, the Verdi project, was characterized by a predominantly hard approach towards systems development and implementation. Performance contribution issues were the main drive behind developing new office technology, meaning that the parties involved, especially the management and IT experts, stressed that the new office technology should contribute to the performance of the organization. Users were moderately involved, mainly as information providers regarding the current work processes. They had no formal decision-making abilities.

The spirit of the DIS can be characterized as control to increase efficiency and performance, to reduce costs and to create a paperless work process. This spirit of the new office technology did not seem to be really clear to users at the moment the DIS was implemented. In the ongoing use stage users appropriated the new office technology to quite a high extent, but appropriating the new system in accordance with the spirit was not without problems (e.g. should the new system be considered as an efficiency increaser, or should this aspect be forgotten). There were also still significant differences between users regarding the way they appropriated the new system. 
In terms of outcomes, users judged the work processes to be moderate is effective. The new office technology brought about quite some unanticipated changes. The project budget was well exceeded, as was the project schedule.

We tested the three hypotheses as formulated in chapter 2 . The results showed that users who were involved in the "Verdi" project had a clearer image of the spirit of the DIS than those who were not involved. Users who found the spirit clear appropriated the DIS to a higher extent than users who did not. In particularly, a clear spirit was positively, and statistically significantly related to perceived usefulness of the DIS, ease of use of the DIS, and the level of taskoriented use of the DIS. Surprisingly, the clarity of spirit was only weakly positive related to the level of faithful appropriation.

Finally, there was not clear positive relationship between the level of appropriation of the DIS and the level of work process effectiveness in unit A. In this case study, it was only the perceived usefulness of the DIS and the level of consensus on appropriation that were significantly positively related to work process effectiveness. Appropriation of the DIS would probably have contributed more positively to work process effectiveness, if the work process had been reorganized alongside the development and implementation of the DIS.

Overall, the results from this case suggest that the Verdi project would have gained from involving users more, and in an earlier stage of the project. Users would then have been able to discuss the intentions of the DIS from the start. Furthermore, incorporating the DIS into the day-to-day activities of users could have led to benefits, since the intention of the DIS would have then been clearer and probably less control-oriented. 


\section{Five}

\section{A call center support system project}

\subsection{Introduction}

This chapter describes the process of an office technology project in a large Dutch bank. It concerns the development, implementation and use of a system that is used by call center employees to support them when talking to clients wishing to arrange a loan over the phone. The project took place over the period from the end of 1998 until the end of 1999.

\subsection{The organizational context}

The office technology project described and analyzed in this chapter took place in a call center of a large Dutch bank, refered to as unit B. This Dutch bank has existed for over 175 years and focuses on commercial banking (individual customers) as well as on investment banking (businesses). In this way the bank tries to spread risks. Its turnover in 1999 amounted to $€ 12628$ million, of which around one-third was in the Netherlands and two-thirds in the rest of the world, particularly in the mid-west of the USA, Brazil, and Southeast Asia. The bank has 915 local offices in the Netherlands and 2606 in the other parts of the world. The total number of employees in fte's (full time equivalents) amounted to 87 797 in 1999, of which 25634 were in the Netherlands.

In 1995 the bank began to set up two call centers in the Netherlands (one in the north, one in the southeast) as a result of a project that aimed to increase sales using by the concept of multi-distribution (selling products through various channels, such as local offices, intermediaries, and call centers). Call centers were a relatively new phenomenon in 1995 within the bank, and were considered as supporters of the local offices, not as alternatives. The new call center in the north of the Netherlands serves the insurance market, and the one in the southeast serves the credit loan market, the stock trade market, and functions as an information service to clients. The call center in the southeast, earlier refered to as unit $B$, is where the office technology project took place that is the subject of this study.

The "Loan Line" is a product of the bank that gives clients the possibility of closing a money loan by phone. Clients call a central telephone number and are connected to unit $B$ after they have gone through a voice-response system. $A$ front-office employee serves the client over the phone by inventorising the 
client's wishes and going through a number of steps to collect the information needed to close a money loan. Only for such front-office activities have office technologies been developed, the back-office activities have to be done by hand. The main functionalities of the Loan Line system are data entry and retrieval, cost calculations of a money loan for clients, and determining conditionally whether a loan can be given or not. After a client has satisfied a number of basic criteria, the data are sent to the back office by fax, where the official documents are typed and sent out.

\section{Typification of the office}

In terms of the taxonomy in chapter one, the office in our unit of study can be typified as a procedural office. At the operational level, unit B consists of groups of individuals (labeled as departments) that operate PCs in order to process information. The primary process of unit $B$ is processing requests for a loan. Employees at the operational level carry out sets of explicit steps towards a specified end.

\section{Characteristics of the employees}

40 employees are involved with the "Loan Line", 34 in the front office and 6 in the back office. Almost two-thirds of the employees are female, their average age is 32 , and the average period they have worked for unit $B$ is 23.2 months. Most employees have a bachelor's or an MBA degree $(62,9 \%)$.

\subsection{The project "Loan Line 2.0"}

\subsubsection{Methodology}

In studying the "Loan Line 2.0" project we used conversational interviews, documents, observations, and questionnaires. The conversational interviews were held with: the chair of the steering committee, the business project manager, the IT project manager, the Infrastructure project manager, all other project team members and former project members, three system developers, a user-training representative, and four non-managerial users. In addition we studied documents, such as approach plans and observed the system while being used by employees. Finally, we asked the employees who used the system to complete a questionnaire. In the rest of this chapter the terms employees and users are mutually exchangeable.

\subsubsection{Project characteristics}

In the view of unit B's management, the time between a client's request for a loan by phone and the moment when the client really has the money at their 
disposal was too long. Besides this, the call center was unable to take part in intensive marketing campaigns, and the back office activities were judged as too labor intensive. The bank's internal project office started by writing a project proposal. In February 1998, this proposal was complete and approved by a central project steering committee and this is seen as the real start of project "Loan Line 2.0". The project's aim was to develop a new office technology system to replace the current system. The aspect that was stressed most in the goals of the new system was an improvement in the current loan line's efficiency. A project management team was appointed and the project organization is established. The project management team consists of a Business project manager, an IT project manager, and an Infrastructure project manager. The Business project manager,referred to as the project manager, had the final responsibility for project "Loan Line 2.0 " the central steering committee. The IT project manager is responsible for supplying the IT services. The Infrastructure project manager takes care of the technical consequences of developing and implementing a new IT system for the technical infrastructure of the bank as a whole.

The project management has to cooperate with different internal parties during the project, such as the "Multi-channel" project team (a team working on a project to transform the bank from a company that can be approached only through local offices and to an extent by phone, into a company that can be approached through all kinds of channels: e-mail, internet, telephone etc.), Marketing, Product Development, and a representative of unit B. The project management team together with the representatives of the various parties that are involved during the project forms what we will call the project team.

Somewhere around April 1998 it became clear that the project "Loan Line 2.0" had to consider the consequences of a decision by the board of directors of the bank to improve the company's financial risk management. Therefore clients would have to be screened more intensively before financial risks were taken and client information should be used better to predict future financial risks. This decision had company-wide consequences. All information systems that are used within the bank for closing mortgages, consumer credits, insurances etc. have to be redesigned in order that they can meet this new financial risk policy. This also meant that the new system for the Loan Line should anticipate this, but the project management found the company's new policy insufficiently clear to incorporate it into the project "Loan Line 2.0". If incorporated, the consequences of the new risk management policy would be quite considerable, because it required adjustments to the new system that were not desireable from a commercial point of view.

In September 1998, the project manager decided to formulate a new project proposal in order to restart project "Loan Line 2.0". He believed that, during the temporary halt of the project, new insights emerged. 
By the end of 1998, the project management had finished the new project proposal and submitted it to the central project steering committee. The project management planned to implement the new loan line system on the $8^{\text {th }}$ of August 1999. During the forthcoming period several people involved as project team members would leave the project, mainly because they were allocated to other projects by the central steering committee. The project management found this very disturbing, a lot of built-up know-how flows out of the project.

The date of implementation moved back to the 30th of October 1999. As planned, the implementation of the new loan line system occured during the weekend of 30/31 October 1999. But, unfortunately, this implementation had to be withdrawn since a specific screen display not included in the new system and front office employees cannot store certain data in the new system. The project management chose a new date for implementation: 28 November 1999. This time the implementation was successful and "Loan line 2.0" became operational.

Table 5.1 presents the characteristics of the "Loan Line 2.0" project from an office technology development and implementation methodological point of view.

\begin{tabular}{|l|l|}
\hline $\begin{array}{l}\text { Characteristic } \\
\text { Management } \\
\text { development } \\
\text { priorities = } \\
\text { technical } \\
\text { optimization }\end{array}$ & $\begin{array}{l}\text { The "Loan Line 2.0" project was predominantly initiated by the drive to } \\
\text { technically optimize the current primary process, but was also supported by } \\
\text { complaints from unit B's employees (both front and back office employees) } \\
\text { about the shortcomings of the office technology in use. The system in use } \\
\text { was outdated and not pleasant to work with. Thus, in reality unit B's } \\
\text { employees pushed the need for a new system (already over a long time) } \\
\text { which could make their work more pleasant, and this way of reasoning could } \\
\text { be translated into arguments for technical optimization by the management. }\end{array}$ \\
$\begin{array}{l}\text { The main reason however to start "Loan Line 2.0" (after a false start) was that } \\
\text { the old system had to made technically suitable for the new 'risk } \\
\text { management' policy of the bank as a whole. Thus, technical optimization } \\
\text { dominated. }\end{array}$ \\
\hline $\begin{array}{l}\text { Extent of user } \\
\text { participation }= \\
\text { Low to } \\
\text { moderate }\end{array}$ & $\begin{array}{l}\text { making process. When the functional design was being written, users were } \\
\text { involved to present their ideas about the new system. The project manager } \\
\text { also observed unit B. Nevertheless, the extent of user participation is typified } \\
\text { as low to moderate, because they were not nvolved in the sense that users } \\
\text { really could give immediate suggestions about elementary aspects of the } \\
\text { system. The essentials of the new system had already been decided or were } \\
\text { going to be decided by the project management. }\end{array}$ \\
\hline
\end{tabular}

Table 5.1 The characteristics of the "Loan line 2.0"- project (continued on next page) 


\begin{tabular}{|l|l|}
\hline \multicolumn{1}{|c|}{ Characteristic } & \multicolumn{1}{c|}{ Description } \\
\hline $\begin{array}{l}\text { Approach to } \\
\text { problem } \\
\text { investigation }= \\
\text { Top down }\end{array}$ & $\begin{array}{l}\text { The problems which were the breeding ground for the start of project "Loan } \\
\text { Line 2.0" were very much defined by management. It was also believed that } \\
\text { the problems could be solved with a technical solution (by improving the } \\
\text { office technology in use, not the social 'system'). The problemwas not really } \\
\text { considered from a more holistic view. }\end{array}$ \\
\hline $\begin{array}{l}\text { Approach to } \\
\text { system } \\
\text { modelling }= \\
\text { predominantly } \\
\text { function } \\
\text { oriented }\end{array}$ & $\begin{array}{l}\text { The new "Loan Line 2.0" was predominantly modeled in terms of functions } \\
\text { that the system should include. In order to write down the new system's } \\
\text { requirements, a few sessions were held with future users, and the project } \\
\text { manager visited unit B to get a picture of the work situation. This was very } \\
\text { much done to get insight into the steps of the primary process, which had to } \\
\text { be the functions of the new system. It was not really the case that the model } \\
\text { of the new system was outlined in terms of human processes that could meet } \\
\text { the objectives of the system. }\end{array}$ \\
\hline $\begin{array}{l}\text { Control of } \\
\text { development } \\
\text { process }= \\
\text { predominantly } \\
\text { formal and } \\
\text { structured }\end{array}$ & $\begin{array}{l}\text { The "Loan Line 2.0" project was very much controlled in a formal and } \\
\text { structured way. The process was divided into clear steps that had to result in } \\
\text { an official document to be approved by the project team and finally the } \\
\text { steering committee. }\end{array}$ \\
\hline $\begin{array}{l}\text { Project life cycle } \\
\text { time scale = } \\
\text { long }\end{array}$ & $\begin{array}{l}\text { The project life cycle of project "Loan Line 2.0" was long. The project } \\
\text { description made clear that first the complete system was to be developed, } \\
\text { then tested, and implemented with a so-called 'big bang'. There was no } \\
\text { evidence of short, intermediary steps, in which parts of the new system were } \\
\text { offered to users in order to test it. }\end{array}$ \\
\hline $\begin{array}{l}\text { Project life cycle } \\
\text { model = } \\
\text { predominantly } \\
\text { 'Waterfall' }\end{array}$ & $\begin{array}{l}\text { From the project characterization as above, it is quite obvious to typify the } \\
\text { project life cycle model as a 'waterfall' one. No signs of evolutionary aspects, } \\
\text { for example by intermediary steps in which users try out components of the } \\
\text { new system, were identified. }\end{array}$ \\
\hline
\end{tabular}

Table 5.1 The characteristics of the "Loan line 2.0"- project

From the description of the project characteristics, as presented in Table 5.1 , we draw the conclusion that, overall, the office technology approach can be typified as hard.

\section{Management contribution}

The call center managements' opinion that the efficiency of the primary process of the Loan Line was not satisfactory was the main drive behind starting project "Loan Line 2.0". Later, when the project proposal was rewritten, an extra drive for project "Loan Line 2.0" arose. The steering committee approved the new project proposal because the loan line system in use should be appropriate for the new "Multi-channel" policy, including the new financial risk policy. This reflects the fact that performance contribution issues were emphasized. The project manager did not support this specific point of departure. In his view the "Loan Line 2.0" project should improve the efficiency of the Loan Line. However, this reflects that the emphasis was put on performance contribution issues. 
During the design stage the project manager visited the call center a number of times in order to map the actual work processes. This indicates that he also recognized organizational environment issues. The project manager assumed that by building a system that suited the current work processes would increase the chances of the project being successful. Furthermore, the project manager explicitly expressed that he wanted users to be involved. The project manager believed that involving users was the best way to meet users' needs and thus permission was given to two users to participate in a workshop with the whole project team at a certain stage of the project. This reflects that a certain amount of attention was paid to human issues by (a representative) of the management.

\section{IT experts' contribution}

In the "Loan Line 2.0" project only internal IT experts were involved. Unit B itself developed the new system, Loan Line 2.0. It was not bought externally. Because of this in-house development, Loan Line 2.0 could be built in line with the current design of the organization without needing much discussion. Organizational environment issues therefore were not emphasized explicitly by IT experts. The IT project manager and the Infrastructure project manager supported the ideas in the project proposal, which predominantly stressed performance contribution issues.

\subsubsection{User involvement}

In Table 5.1 the extent of user participation in the "Loan Line 2.0" project was characterized as low to moderate. Table 5.2 presents the level of user involvement at each project stage.

\begin{tabular}{|l|l|l|l|l|l|l|l|}
\hline Stage of the "Loan line 2.0"-project & $\mathbf{2}$ & $\mathbf{3}$ & $\mathbf{4}$ & $\mathbf{5}$ & $\mathbf{6}$ \\
\hline Initial decision-making & $\mathrm{x}$ & & & & & \\
\hline Requirements analysis & & & & $\mathrm{x}$ & & \\
\hline Functional design & & $\mathrm{x}$ & & & & \\
\hline Technical design & $\mathrm{x}$ & & & & & \\
\hline Technical realization & $\mathrm{x}$ & & & & & \\
\hline Testing & & & $\mathrm{x}$ & & & \\
\hline Implementation & $\mathrm{x}$ & & & & & \\
\hline
\end{tabular}

$1=$ no or minimal information, 2 = information, $3=$ opportunity to give advice, $4=$ advice taken into consideration, 5 = joint decision making, 6 complete control.

Table 5.2 User involvement in each development stage of the "Loan Line 2.0" project 
Unit B's employees, the future users of the new office technology, were especially involved during the requirement analysis stage. One front-office agent and one back-office employee took part in a workshop aimed at writing down the new system's requirements. In this stage, their involvement concerned the possibility of giving advice to be taken in consideration. During other stages, users played a less prominent role. Only in the system tests were users also in the position to give advice but this could hardly be acted upon as the new "Loan Line 2.0 " was basically complete. However, during the tests a lot of faults in the system did show up.

\subsubsection{The clarity of the spirit}

The spirit of "Loan Line 2.0" at the end of the initial development stage can be characterized as control to improve financial risk management and efficiency. In the figure below this spirit is visualized and 'deconstructed' into some of its main structures.

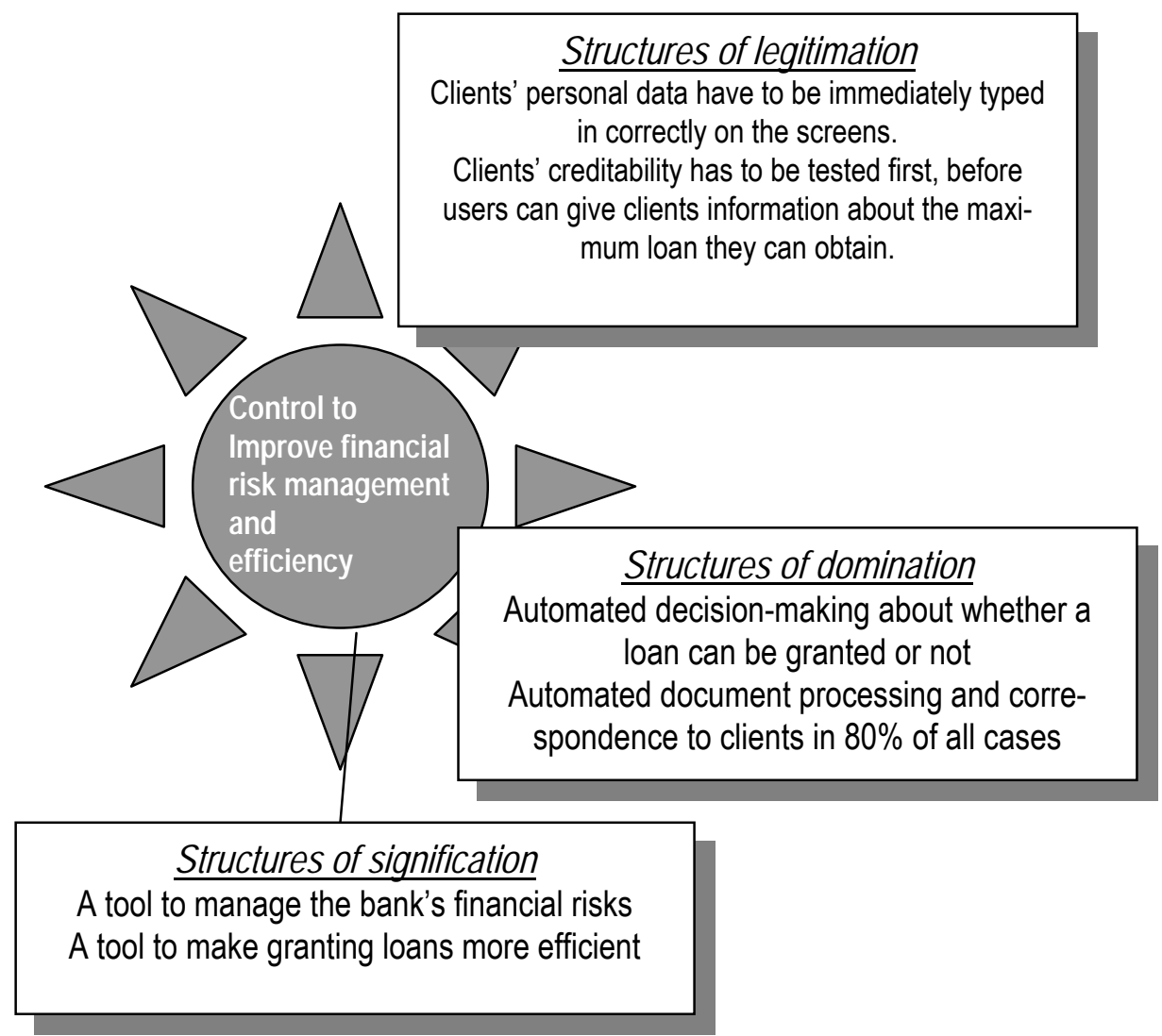

Figure 5.1 The spirit of "Loan Line 2.0" in the initial development stage 'deconstructed' into examples of its main structures 
In Figure 5.1 we describe the new office technology's spirit. "Loan Line 2.0's" spirit can be best put in the following terms: control to improve financial risk management and efficiency. Most of all, in our opinion, control is the central word. The underlying philosophy of "Loan Line 2.0 " is to achieve more control over the primary process, in order to reduce financial risks and to make it more efficient. Figure 5.1 shows examples of the main structures the new system 'promotes' to users.

The technical features of "Loan Line 2.0", in order to realize the system's spirit, are described in table 5.3 below:

\begin{tabular}{|l|l|l|}
\hline Criteria & Description & Qualification \\
\hline $\begin{array}{l}\text { Level of } \\
\text { restrictiveness }\end{array}$ & $\begin{array}{l}\text { "Loan Line 2.0" consists of a number of screens that } \\
\text { users have go through in a predetermined way. There } \\
\text { are a few options to 'change' the standard sequence, } \\
\text { but these do not really allow an alternative sequence. } \\
\text { These options are just 'timely' step outs. }\end{array}$ & High \\
\hline $\begin{array}{l}\text { Level of } \\
\text { sophistication }\end{array}$ & $\begin{array}{l}\text { The new system is quite simple in nature; it can only be } \\
\text { used for activities within the primary process, and does } \\
\text { not contain any multi-media features. }\end{array}$ & Low \\
\hline $\begin{array}{l}\text { Degree of } \\
\text { comprehen } \\
\text { siveness }\end{array}$ & $\begin{array}{l}\text { "Loan Line 2.0" is not 'window-based', which means } \\
\text { that users cannot open more than one screen } \\
\text { simultaneously and have to go through the screen flow } \\
\text { as given. The number of features the system offers is } \\
\text { low, as is the variety of features. }\end{array}$ & Low \\
\hline
\end{tabular}

\section{Table 5.3 Typification of "Loan line 2.0's" technical features}

The spirit of the new system was not very clear to users when it was offered to them. During the first one and a half weeks the project management team was present at unit B to assist the users. This period was longer than the project management had expected initially. It appeared necessary as employees of unit B were quite confused and had many questions about "Loan Line 2.0".

\subsubsection{Appropriation of "Loan Line 2.0"}

As noted, during the first one and a half weeks after the implementation of "Loan Line 2.0", users were quite confused. With the implementation of the new system it was expected that the personal data of clients that were put into the system by the front-office employees would no longer have to be checked in the back-office. The new loan-line system automatically produced the final physical documents, such as the contract to be sent to the client after front-office employees had agreed a money loan. But in the initial weeks after "Loan Line 2.0 's" introduction, it became clear that front office employees were not fully 
aware of the fact that they must not make mistakes. Back-office employees were forced to check the contracts before sending them out, because of the number of errors made by front-office employees. Front office employees experienced that the training did not pay enough attention to this aspect.

In general, the users of "Loan Line 2.0", the front and back office employees, were quite disappointed with the new system. They felt that their needs were not fulfilled. The front office employees experienced that "Loan Line 2.0" required more 'moves' than the old system, eventhough the new system had less functional possibilities. In their view, clients could not be served optimally, which led to dissatisfaction by front-office employees. They also experienced that the sequence of screens in the new system was not optimal. Front-office employees, as well as back-office employees, found it disappointing that "Loan Line 2.0" did not include facilities for a new product which had already obtained a market share of more than $50 \%$. More than half of the clients called for this new product rather than the already existing product. The loan line employees had to handle this new product by hand.

The back-office employees found it hard to accept that the new system, in some cases, used other criteria for deciding whether a client could have a loan than those the back office employees used with the old system. Back office employees experienced that the new system allowed a loan to people who would not get one if they produced the physical documents by hand. This lack of clarity about criteria led to a workshop being organized by the project management for front and back office employees about the rules for money loans.

After around two months users had incorporated the new system in such a way that it was possible to speak of stable use. The stage of ongoing use had started. In the table below the way users appropriated "Loan Line 2.0" in this ongoing use stage is described for each dimension. 


\begin{tabular}{|c|c|}
\hline $\begin{array}{l}\text { Aspects of } \\
\text { appropriation }\end{array}$ & Description \\
\hline $\begin{array}{l}\text { Appropriation } \\
\text { moves = high }\end{array}$ & $\begin{array}{l}\text { In the ongoing use stage users appropriated the new system to quite a } \\
\text { high extent, mainly because they had to. "Loan Line } 2.0 \text { " was a necessary } \\
\text { tool to carry out the day-to-day activities. }\end{array}$ \\
\hline $\begin{array}{l}\text { Faithfulness of } \\
\text { appropriation = } \\
\text { moderate }\end{array}$ & $\begin{array}{l}\text { Users appropriated the system partly in line with its spirit. They accepted } \\
\text { that decision-making about whether a loan could be granted or not was } \\
\text { automated. Users also 'incorporated' the structure that the new system } \\
\text { processed the data and took care of correspondence with clients. On the } \\
\text { other hand, users sometimes committed 'acts of sabotage' towards the } \\
\text { system's spirit by getting around the given screen flow. }\end{array}$ \\
\hline $\begin{array}{l}\text { Attitude } \\
\text { towards the } \\
\text { DIS (perceived } \\
\text { usefulness) = } \\
\text { low to } \\
\text { moderate }\end{array}$ & $\begin{array}{l}\text { Overall, users did not experience the new system as highly useful. The } \\
\text { system was useful in the sense that the day-to-day work had to be carried } \\
\text { out with it, but "Loan Line } 2.0 \text { " did not really meet the intention of users. }\end{array}$ \\
\hline $\begin{array}{l}\text { Attitude } \\
\text { towards the } \\
\text { DIS (perceive } \\
\text { ease of use) = } \\
\text { low to } \\
\text { moderate }\end{array}$ & $\begin{array}{l}\text { In the ongoing use stage users found a new balance between what they } \\
\text { were used to, and what they got after the introduction of "Loan Line } 2.0 \text { ". } \\
\text { Nevertheless, users found the new system less easy to use than the old } \\
\text { system. }\end{array}$ \\
\hline $\begin{array}{l}\text { Task oriented } \\
\text { use = } \\
\text { moderate to } \\
\text { high }\end{array}$ & $\begin{array}{l}\text { The level of task oriented use was moderate to high in the ongoing use } \\
\text { stage, but this was partly due to the fact that "Loan Line } 2.0 \text { " was a } \\
\text { necessary tool for the day-to-day activities. To an extent "Loan Line } 2.0 \text { " } \\
\text { could not be appropriated as task oriented since it did not contain features } \\
\text { to process unit B's new product that had been introduced on the market. } \\
\text { This product had to be processed manually. }\end{array}$ \\
\hline $\begin{array}{l}\text { Explorative } \\
\text { use }= \\
\text { moderate }\end{array}$ & $\begin{array}{l}\text { In the ongoing use stage users were still finding out how to appropriate the } \\
\text { structures of the new system to some extent. }\end{array}$ \\
\hline $\begin{array}{l}\text { Consensus } \\
\text { among users } \\
\text { on } \\
\text { appropriation = } \\
\text { low to } \\
\text { moderate }\end{array}$ & $\begin{array}{l}\text { Due to the disappointment of users with the new system, users tried to find } \\
\text { different ways to appropriate the new system' s features. This resulted in } \\
\text { different styles of appropriation. For example: users dealt differently with } \\
\text { the given screen flow, some got around it in order to apply the system in } \\
\text { accordance with what they were used to, others followed the screen flow } \\
\text { provided. }\end{array}$ \\
\hline
\end{tabular}

Table 5.4 The level of users' appropriation of "Loan line 2.0"

Overall, the level of appropriation of "Loan line 2.0" was moderate. Users mainly appropriated the new system because it was a necessary tool for their 
day-to-day activities (resulting in a quite high level of appropriation moves and task oriented use). They did not perceive the system as useful or easy to use.

\subsubsection{The context of appropriation of Loan Line 2.0}

The contextual factors as discerned in our research model had the following characteristics in the "Loan Line 2.0" project (Table 5.5):

\begin{tabular}{|c|c|}
\hline Characteristic & Description \\
\hline $\begin{array}{l}\text { Level of change } \\
\text { in the internal } \\
\text { organization }\end{array}$ & $\begin{array}{l}\text { The "Loan Line } 2.0 \text { " project had no intention to change the internal } \\
\text { organization, except for the reduction of labor in the back office. No } \\
\text { signs were identified to change the content of jobs by purpose. } \\
\text { Changes in 'organization design' aspects that did occur were only as a } \\
\text { result of the way users worked with the new system. }\end{array}$ \\
\hline $\begin{array}{l}\text { Level of work } \\
\text { autonomy after } \\
\text { implementation }\end{array}$ & $\begin{array}{l}\text { The level of work autonomy after implementation of the new system } \\
\text { was low to moderate. Unit B's employees, especially the front-office } \\
\text { agents, did experience that they were quite bounded by the phone and } \\
\text { the office technology in serving clients. Back-office employees were not } \\
\text { tied to incoming phone lines. They felt more like a small team that had } \\
\text { to process the formal (paper work) part of granting loans. After the new } \\
\text { system's introduction their jobs did not really change, although it had } \\
\text { been intended to reduce labor in the back office. That this did not } \\
\text { happen was due to the introduction of the new product, which had to } \\
\text { be dealt with manually. }\end{array}$ \\
\hline $\begin{array}{l}\text { Satisfaction with } \\
\text { implementation } \\
\text { process }\end{array}$ & $\begin{array}{l}\text { The implementation of "Loan Line } 2.0 \text { " occurred using a so-called 'big } \\
\text { bang' scenario. The new system was completely implemented } \\
\text { throughout the organization at one time. This went wrong the first time, } \\
\text { which disappointed users. Furthermore, users experienced the training } \\
\text { as rather 'theoretical' and 'difficult'. }\end{array}$ \\
\hline $\begin{array}{l}\text { Satisfaction } \\
\text { about the } \\
\text { reasons for new } \\
\text { system } \\
\text { development }\end{array}$ & $\begin{array}{l}\text { Initially, users were enthusiastic about the development of a new } \\
\text { system, because the system in use was 'outdated'. The new system as } \\
\text { implemented however differed considerably from what users expected. } \\
\text { "Loan Line } 2.0 \text { " was not easier to use than "Loan line 1.0". It was even } \\
\text { experienced as more difficult. }\end{array}$ \\
\hline $\begin{array}{l}\text { Satisfaction } \\
\text { about support } \\
\text { when having } \\
\text { problems during } \\
\text { the ongoing use } \\
\text { stage }\end{array}$ & $\begin{array}{l}\text { During the first weeks after the implementation of "Loan Line } 2.0 \text { " users } \\
\text { were satisfied with the fact that the project management was present at } \\
\text { unit B to support users having problems. However, after the initial } \\
\text { weeks, only the trainer was available for support with problems. Further } \\
\text { support, for example from the unit's management, was not } \\
\text { experienced. }\end{array}$ \\
\hline
\end{tabular}

Table 5.5 "Loan Line 2.0"-project context characteristics 
Users experienced a low level of change in their work environment following the implementation of "Loan Line 2.0". After implementation, users' level of work autonomy was low to moderate. Users were moderately positive about the reasons for developing "Loan Line 2.0", and quite negative about the implementation process. Users' satisfaction with the support when having problems with "Loan Line 2.0" was moderate.

\subsubsection{Project outcomes}

The outcomes of the project are shown in Table 5.6.

\begin{tabular}{|c|c|}
\hline Outcome & Description \\
\hline $\begin{array}{l}\text { Work process } \\
\text { effectiveness } \\
=\text { low to } \\
\text { moderate }\end{array}$ & $\begin{array}{l}\text { Users rated work process effectiveness in the ongoing use stage as low } \\
\text { to moderate. It was not really believed that the work processes were } \\
\text { effective in the ongoing use stage. Partly, this was due to the fact that } \\
\text { unit B's new product had to be processed manually. Front-office } \\
\text { employees, as well as back-office employees still felt it was problematic } \\
\text { that front-office employees had to type in clients' data correctly since the } \\
\text { system produced the formal documents automatically, and every } \\
\text { spelling or typing error was printed on the documents. }\end{array}$ \\
\hline $\begin{array}{l}\text { Unanticipated } \\
\text { changes = } \\
\text { moderate }\end{array}$ & $\begin{array}{l}\text { The implementation of "Loan Line } 2.0 \text { " brought about a number of } \\
\text { unanticipated changes. The spirit of the new system 'forced' users to } \\
\text { direct more clients to the local offices, because users were not allowed } \\
\text { to serve them. This was not foreseen. Users felt that they could not } \\
\text { better serve clients than before. Back-office employees had to check the } \\
\text { printed documents for spelling errors made by front-office agents. Front- } \\
\text { office agents had to be taught a general code about the way to write } \\
\text { clients' personal data (when to use capitals etc.). An important change: } \\
\text { it was not anticipated that when the new system would be implemented } \\
\text { the Loan Line's work was to a large extent unit B's new product. } \\
\text { Therefore "Loan Line } 2.0 \text { " did not lead to a reduction of labor in the back } \\
\text { office. }\end{array}$ \\
\hline $\begin{array}{l}\text { Anticipated } \\
\text { changes = } \\
\text { moderate }\end{array}$ & $\begin{array}{l}\text { The implemented system brought about a moderate level of change as } \\
\text { anticipated. We have already oberved that the implementation of "Loan } \\
\text { Line } 2.0 \text { " was not accompanied by a high level of organizational change. } \\
\text { Examples of anticipated changes: the new system 'took over' the } \\
\text { processing of the formal documents (which was done manually before), } \\
\text { and the new system took over decision-making on whether a loan could } \\
\text { be granted or not. }\end{array}$ \\
\hline $\begin{array}{l}\text { Project costs } \\
=\text { budget far } \\
\text { exceeded }\end{array}$ & $\begin{array}{l}\text { We do not have exact figures for the project's initially planned costs and } \\
\text { the exact final costs. However, we do know that the project exceeded its } \\
\text { initially planned costs quite considerably. }\end{array}$ \\
\hline
\end{tabular}

Table 5.6 Project outcomes 
What becomes clear from table 5.6 is that the implementation of "Loan Line 2.0" did not really contribute to work process effectiveness at unit B. The project brought about quite some unanticipated changes in Unit B, resulting in a number of additional problems. The level of anticipated change that "Loan Line 2.0 " brought about was moderate. The "Loan Line 2.0" project exceeded its planned budget quite considerably.

\subsection{Testing the hypotheses}

\subsubsection{Hypothesis 1}

The first hypothesis to test is:

The extent to which users have a say in the development and implementation of an office technology is positively related to the clarity of the spirit to users.

The result of testing this hypothesis is shown below.

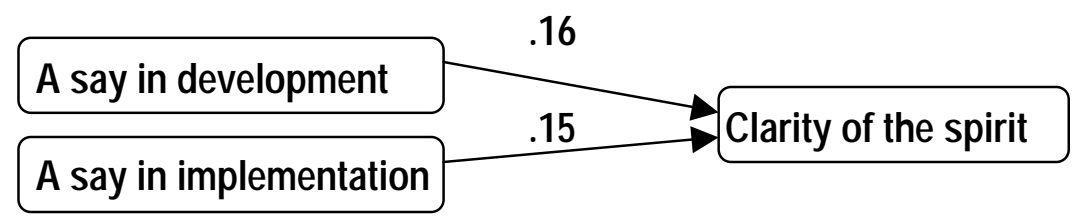

Figure 5.2 the relationship between having a say in the development and implementation, and the clarity of spirit $(\mathrm{N}=27)$

From the project description in section 5.3 we saw that, in unit $B$, users in general were only lowly involved in the "Loan Line 2.0" project. Figure 5.2 shows that users who did have a say do not really find the spirit any clearer than those who were not involved. Thus, we must conclude that our hypothesis is not confirmed. How can this be explained? We think that the explanation is that user involvement only took place in the requirements analysis and the testing stages. Following the requirements analysis stage the system design went through quite a number of changes, and in the test stage the system showed up many errors. The new system that was eventually implemented differed therefore to quite an extent from what was expected by users. Thus, even for users who had been involved, it is conceivable that they found it problematic to get a clear picture of the new system's spirit. 
These results suggest that it is essential that users are involved in all stages, and not only in one specific stage. Furthermore, system requirements should not be changed without involving users.

\subsubsection{Hypothesis 2}

The second hypothesis is:

The clarity of the spirit of office technology is positively related to the level of appropriation

The figure below shows the results of the statistical analysis.

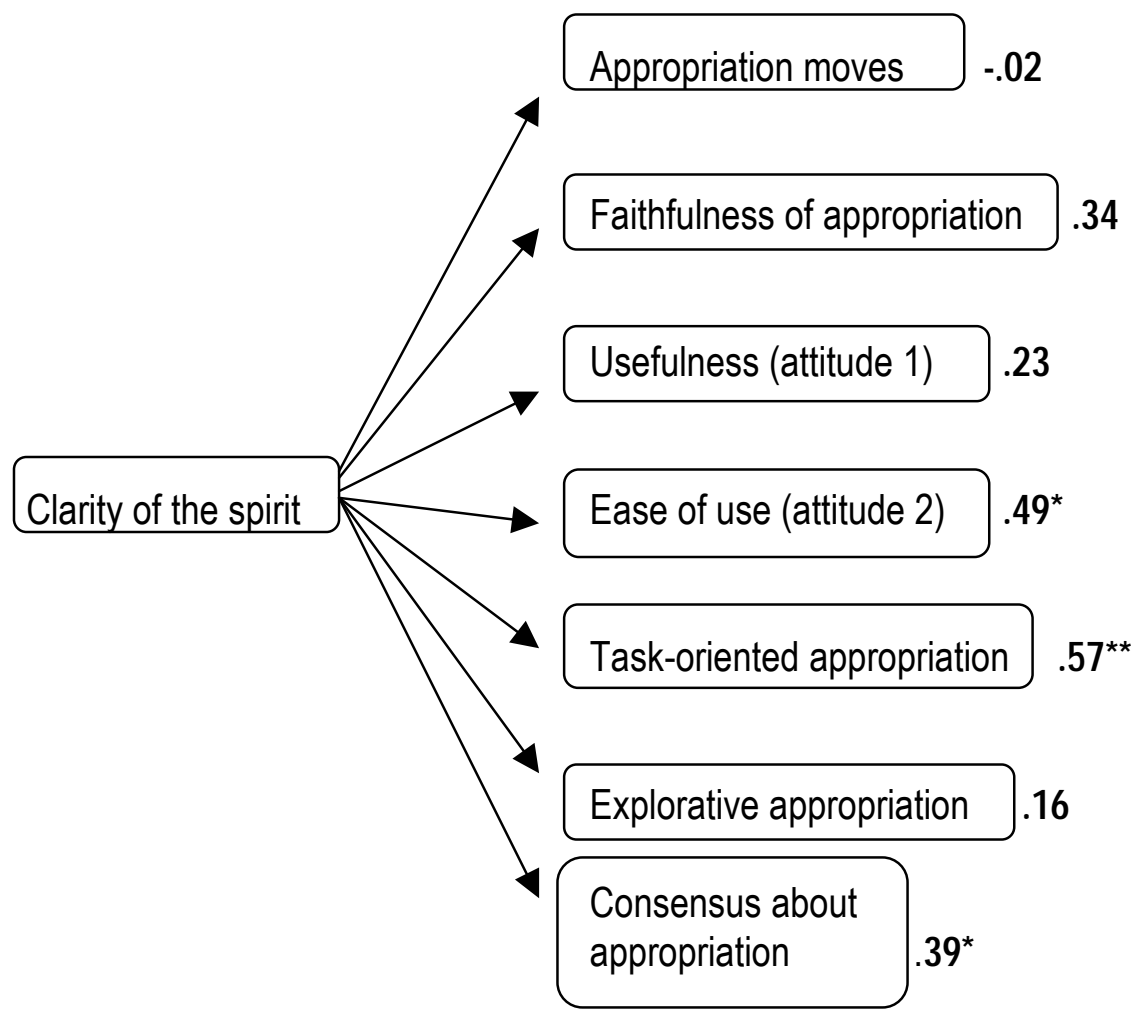

${ }^{*}=p<0.05 ;{ }^{* *}=p<0.01$

Figure 5.3 The relationship between the clarity of the spirit and the level of appropriation ( $\mathrm{N}=27)$

Regarding the results from unit B presented in figure 5.3 we can observe that the clearer the spirit to users, the higher the extent of faithful appropriation (albeit not significantly), perceived usefulness of "Loan Line 2.0", perceived ease of use of "Loan Line 2.0", task-oriented use, and level of consensus. The clarity 
of spirit is not or, at best barely positively related to the level of appropriation moves and explorative use.

That the clarity of spirit does not have an influence on the level of appropriation moves is not that strange, although this is not in line with what we had initially expected. In unit B users had to use the new system's features since the new system was their main tool for carrying out their daily work. In the most extreme situation users, of course, could have rejected the system and continued to process data manually, but this would have been a very rigorous act.

Overall, the results from testing this hypothesis indicate that, the more users find the spirit of "Loan Line 2.0" clear, the more they appropriate the system in line with its spirit, perceive the system as useful and easy to use, work with it in a task-oriented way, and experience consensus with other users on how to appropriate the system. In conclusion, with regard to our second hypothesis, we conclude that it is confirmed within the context of unit $B$.

\subsubsection{Hypothesis 3}

Finally, the third hypothesis will be tested. Previously, we concluded that, in project "Loan Line 2.0", the clarity of the spirit of the office technology was positively related to the level of appropriation. In our third hypothesis, we expect that the level of appropriation is related to the effectiveness of the work processes.

The level of office technology appropriation is positively related to the effectiveness of the work processes.

Figure 5.4 shows the results: 

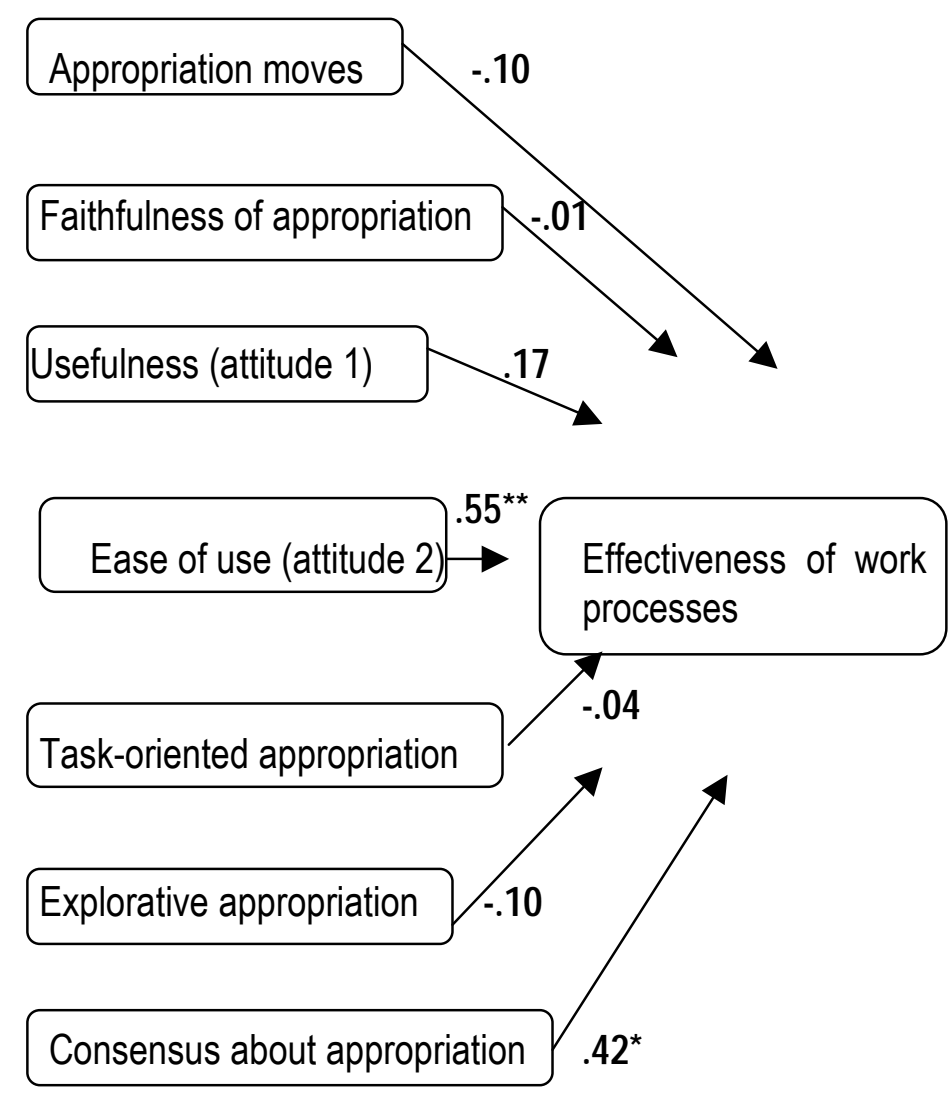

${ }^{*}=p<0.05 ;{ }^{* *}=p<0.01$

Figure 5.4 The relationship between the clarity of the spirit and the level of appropriation

We observe that, in particular, the level of perceived ease of use and the level of consensus on appropriation are positively related to the level of work process effectiveness. This is somewhat 'disappointing' in terms of our theoretical expectations. In the cross case analysis in chapter 8 we involve contextual variables (the level of organizational change and the level of work autonomy) to determine their effect on this relationship. In this chapter, we can only guess the effect of such contextual variables. We can suppose that due to the fact that the "Loan Line 2.0" project was not accompanied by changes in the organization, that the level of work autonomy in the ongoing use stage was low to moderate, and also that the quality of the implementation process being low 
can explain why the appropriation of the system does not contribute to the work process effectiveness.

We must conclude however that, within the context of unit $B$, the third hypothesis is not convincingly confirmed.

\subsection{Summary of findings}

The office technology project in unit B was characterized by a predominantly hard approach towards systems development and implementation. In the project performance contribution properties were the main drive behind developing a new office technology, and so the human actors involved mainly stressed that the new office technology had to contribute to the performance of the organization. Users' involvement in the project was low to moderate. Only in the requirements analysis stage and the test stage did representatives of users have a say in the project.

The spirit of the new system, "Loan Line 2.0", can be characterized as control to improve financial risk management and efficiency. This was not very clear to users when the system was offered to them. In the ongoing use stage, users' level of appropriation of the new office technology was moderate to high. Partly, this was due to the fact that "Loan Line 2.0" was a necessary tool in dayto-day work (resulting in quite a high level of appropriation moves and task oriented use). However, users' perception of the system's usefulness, and ease of use was only moderate and there were still notable differences between users in the way the system was used.

Regarding the project outcomes, in the ongoing use stage, the work processes were only lowly effective. The new office technology brought about a moderate level of unanticipated changes. The project budget was significantly exceeded.

The analysis of the questionnaires led to the following outcomes with regard to our three hypotheses. Within the context of unit B the level of user involvement was only weakly positively related to the clarity of spirit. This can be explained from the observation that although users were involved during the requirements analysis stage, and the test stage, the system's design went through some changes without any user involvement. Next, we observed that the clearer the spirit of "Loan Line 2.0" is to users, the higher the level of appropriation. In particular, a clear spirit was, significantly, positively related to perceived ease of use of the new system, task-oriented use and consensus on appropriation of the new system. This indicates that the project in unit B could have benefited from better management of the non-technical side of "Loan Line 2.0".

Finally, it was clear that the level of appropriation was not convincingly, positively related to work process effectiveness. We suggest that this can be 
explained by the 'ignorance' of anticipated organizational changes in the project, the low level of work autonomy, and by the low quality of the implementation process. 


\section{Six}

\section{An insurance administration system project}

\subsection{Introduction}

Our third case study concerns an office technology project in a unit of a small insurance company in the northwest of the Netherlands. The project, which concerns the development, implementation and use of a health insurance administration system, started in the second quarter of 1998 and ended in the last quarter of 1999. The structure of this chapter is as follows: section 6.2 describes the organizational context of the project. Section 6.3 presents a description of the project as in the former two chapters, and then in section 6.4 we test our three hypotheses. Finally, in section 6.5 , we reflect on our findings in this case study.

\subsection{The organizational context}

The unit in which this office technology project took place is located in the northwest of the Netherlands. This unit specifically focuses on health insurance, and is part of a financial service company. We will call it unit $C$. Unit $C$ is relatively small, with around 72 fte's. This size is typical of most of the companies that operate in the health insurance market. It is a fragmented market with many small providers. Unit C's share of the health care market is $1 \%$.

The larger financial service company of which unit $C$ is a part, in this case called the " $A$ " concern, is a nationally operating financial service-provider active in the consumer as well as the business market. It offers a full range of services, such as credit (financial loans), insurance, pensions, mortgages, investment funds, and saving plans. The "A" concern has 10000 employees and several units. It is one of the largest financial service providers of the Netherlands.

A characteristic of financial service unit $C$ is that it offers its services through intermediaries, insurance offices and independent financial advisors. It is not a so-called 'direct writer'. This is a conscious strategic choice.

The typification of the office

In terms of the taxonomy in chapter 1 the unit office in our study can be typified as a procedural office. In this unit, groups of individuals (divided into 
departments) operate PCs in order to process information. Each department is responsible for a specific general task. This processing of information involves judging requests for insurance policies, processing requests for changes in policies, and entering health costs' bills. Overall, employees carry out sets of explicit steps towards a specified end, as formulated in the description of procedural offices in chapter 1.

\section{Characteristics of the employees}

The group of employees that are the subject of our study can be characterized as follows (based upon a response rate of $67.5 \%$ ): $44.8 \%$ are male, $55.2 \%$ are female. The average age is 30.7 years, and the average time working at unit $\mathrm{C}$ is 6.5 years. The highest education level of $65.5 \%$ of the employees is high school (HAVO, VWO, MBO), and $50 \%$ of the employees work part-time.

\subsection{The project "Better"}

\subsubsection{Methodology}

The office technology project that took place in Unit C was called "Better". Conversational interviews were held with: the general manager (member of the steering committee), the project manager, the project leader for system development, the project leader for the user test team, the manager of Automation and Logistics, and three non-managerial employees. In addition we studied the project plan, and approach plans for separate parts of the project, and observed the system while used by employees. Finally, we asked employees who used the system to complete a questionnaire.

In the remainder of this chapter the terms users and employees are used interchangeably.

\subsubsection{Project characteristics}

The project "Better" has quite a long history. After a merger with another unit, unit C implemented a new platform system in 1994. Its performance appeared to be poor. Sometimes the system had two or three breakdowns in a week and these could even last a few days, and the response time was excessive. Moreover, unit $C$ seemed to be the only subsidiary within the "A" concern that worked with this system, which made future cooperation difficult. Therefore a desire for a new system arose. Unit C's manager of Automation and Logistics (A\&L), who would later be the project manager of the office technology project we studied, therefore started writing a plan at the end of 1996 to implement a new platform and user software. From the management of " $A$ " there 
was a certain 'push' to adopt a system already in use at another of its subsidiaries.

After an initial unsuccessful collaboration with a software company, unit $\mathrm{C}$ was in a very uncomfortable situation since the end of the millennium was drawing near and it seemed that the existing platform was probably not $\mathrm{Y} 2 \mathrm{~K}$ (millennium) proof. Unit $C$ therefore wanted to have the current system replaced before the end of 1999. Another aspect that had become apparent was that the manufacturer of the current platform had made clear that they wanted to quit this business. For unit $C$ this meant that maintenance of the platform would become problematic. All this stressed the need to find a new system. A software company, 'V-soft' observed the needs of unit $C$ and proposed a fast solution: replacing the current platform with a new one without changing the functionalities of the applications that worked on the current platform. Due to time constraints, improvements could not be made in the functionalities of the user applications, although unit C's management team had expressed ideas and wishes to improve certain applications, to an extent based upon users' experiences. The manager when writing the new project plan ignored these wishes.

\section{Start of the project}

In the second quarter of 1998 the office technology project, called "Better", commenced. The primary goal of the project "Better", as defined in the project proposal, was to replace the computer platform in use with a V-soft platform with user applications that offered identical functionalities as the current user applications. The project would take four to six months. A project organization was set up with a steering committee (including the Board of directors of unit $C$, and two representatives from "A"), a project team (consisting of a general project manager and three project team leaders), and three task groups: an IT infrastructure team, a users team, and a system developers team. Unit C's A\&L manager took the role of general project manager.

During the project, it became clear that the initial drive to start the project in unit $\mathrm{C}$ weakened when, at a certain moment, it appeared possible to make the existing platform millennium proof. Also the stability of the old system improved to a satisfactory level when "A"'s central ICT department installed new drives for the system. Another factor that weakened the motivation of the project organization was the fact that " $A$ " was looking at possibilities to implement one common system in all its subsidiaries. This could require a new office technology project shortly after the project "Better" had been completed.

During the tests of the "Better" system, it became clear that the users' component of the system had received too little attention by the system developers. They were confronted with the fact that the old user interfaces contained more functionalities than they had initially expected. Another aspect that showed up during the test was that the new system's performance was 
inferior to that of the old system. This was very disappointing for the users involved in the test as well as for the management team. Users expected a more stable and a faster system.

From that moment on, the developers started to describe the existing system from the current user interfaces, as there was no clear documentation and the developers of unit $C$ had left, so there was a lack of available knowledge. This took a great deal of extra time and, from this moment on the project, according to the project leader for system development and the project leader for the users team, was in a continuous testing stage.

The initial date for implementation, December 1998, was exceeded by almost one year. When the system's performance had been improved to a certain level, the maximum achievable according to the system experts, but still inferior to the old system's performance, the project management decided to implement "Better" throughout the organization.

On the $4^{\text {th }}$ October 1999 , employees of unit $C$ started working with the new system "Better". These employees were able to work with the new system right from the start. Since quite a number of them had been involved in the tests (as they had taken so much time) or had taken a look at "Better" in the test situation. There were also handbooks available. All this resulted in a relatively unproblematic transition. Employees got used to the new system rapidly, although this differed somewhat between departments. In one department, employees were not used to working with a mouse as this took some extra time and energy to get them used to "Better". Besides this, in general, employees experienced the screens of the new system as 'busy' (a lot of data/items on one screen) and considered the font type to be small.

During the first weeks of use, some errors in the system showed up. For example, certain screens, used by only a few employees, were missing and certain data could not be processed because this concerned data that were not processed very often and as a result forgotten. System developers rapidly solved these problems during the first weeks.

One important problem persisted: the system's performance. During the tests the new system was shown to be quite slow, but the system development team had not succeeded in solving this problem. This disappointed employees who worked with "Better", and the management team, especially since during the project the old system's performance had increased due to technical improvements in unit C's system management. The need for a new system therefore had in fact decreased.

After about one and half months, users in general were used to working with "Better". Except for its performance, which was still inferior to the 'old' system's, working with the new system began to show a stable pattern.

Table 6.1 presents the characteristics of the "Better" project from an office technology development and implementation methodological point of view. 
Characteristics

Management

development

priorities $=$

technical

optimization
Description of the development method of the 'Better' project

The initial reasons to start the "Better"-project was the instability of the system in use. This can be explained in two ways, namely as a drive to improve the user's work situation, and as a drive to realize technical optimization. However, we tend to see it mainly as a drive to optimize the system in use technically, especially because improving the user functionalities of the system was kept out of the project. Improving these was considered a too high a risk.

Extent of user participation $=$ moderate

It is interesting to notice how, initially, the user was almost completely kept out of the project, as it was believed that user applications would not change. However, decision-makers (A\&L manager/project manager, board of directors, project team) were not fully aware of the implications of 'just' switching from character-based to graphical screens. Only after the first test did it become apparent what the consequences were of ignoring the users applications. From that moment on, the whole design process had to start all over again. As good documentation on the designs of these applications were lacking, system developers had to map them again directly from the current screens. So, from that moment on, users were more involved, mainly as information providers. However, right from the start of the "Better" project, users were represented in the project team by a team leader who had the position of project manager for the user organization. Therefore, users were represented in the project team from the start of the project, but only in an indirect way.

\begin{tabular}{l|l} 
Approach to & In unit $C$, the problem was very much defined top-down, in the sense that
\end{tabular} problem $\quad$ right from the start it was believed by the A\&L manager that the 'problem' investigation = $\quad$ was very much of a technical nature, and therefore needed a technical Top down $\quad$ solution. Decision-making about this 'problem' was very much a matter for the management alone.

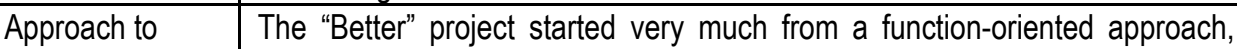
system modeling especially because the problem was very much defined as a technical $=$

predominantly function oriented problem. Later on, when the problem also seemed to have a social, organizational component, users became more 'visible'. But still, when the system had to be mapped over again, it was very much defined in terms of functions the system should have in order to meet the defined objectives.

Control of development process $=$ Initially predominantly formal and structured, later on informal and unstructured. The project process aimed to be very much a formal and structured process, divided into stages, which had to be completed with a formal document. However, this did not proceed in the way expected. In the first tests, when the new system failed completely, the project continued with the characteristics of an informal and much more unstructured and open process. System developers had to communicate directly with users to map the old system straight from the screens and, from that moment on, the new system was then tested piece by piece. The V-soft project manager experienced the projects as a continuous test stage.

Table 6.1 The characteristics of the development method of the 'Better' project (continued on the next page) 


\begin{tabular}{|c|c|}
\hline ics & 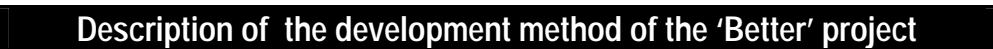 \\
\hline $\begin{array}{l}\text { Project life cycle } \\
\text { time scale = } \\
\text { First long, later } \\
\text { on it switched } \\
\text { to a short life } \\
\text { cycle time }\end{array}$ & $\begin{array}{l}\text { Overall, the "Better' project life cycle must be considered as long. The project } \\
\text { plan aimed to develop the new system first as a whole, and then when it was } \\
\text { ready to implement it. However, as noted earlier, when the first test failed } \\
\text { completely, the project developed another nature. Users tested each new } \\
\text { piece of the system, before the development process continued. Thus, the } \\
\text { project life cycle from that moment on became shorter, albeit unintendedly. } \\
\text { However, the system was not implemented throughout the whole } \\
\text { organization before it was completely ready. }\end{array}$ \\
\hline $\begin{array}{l}\text { Project life cycle } \\
\text { model = Initially } \\
\text { 'Waterfall', later } \\
\text { on somewhat } \\
\text { more } \\
\text { evolutionary }\end{array}$ & $\begin{array}{l}\text { This characteristic in fact summarizes the abovementioned characteristic to a } \\
\text { certain extent, but nevertheless, if we speak in terms of the project life cycle } \\
\text { model, the "Better" project was initially modeled as a 'waterfall'. Later on, } \\
\text { after the first test, the project switched over to a more evolutionary model, } \\
\text { however unintendedly. } \\
\text { The final implementation of the system throughout the organization was } \\
\text { achieved through a so-called 'big bang' scenario, which is a characteristic for } \\
\text { the 'waterfall' model. }\end{array}$ \\
\hline
\end{tabular}

Table 6.1 The characteristics of the development method of the 'Better' project

Considering the descriptions of the project characteristics we draw the conclusion that the "Better" project was intended to apply a hard approach towards office technology development. It had to switch towards a softer approach because, during user testing, the new system failed completely to meet its objectives.

\section{Management contribution}

The project "Better" started as a result of a badly implemented platform system, expressed by a very low performance. The board of directors, the A\&L manager, and the management team, started from the opinion that a system's performance influences the performance of the organization as a whole. That is why they authorized the development of a project plan to implement a system that would improve the performance of the current system. This reflects that the emphasis was on performance contribution issues in the "Better" project.

After the contract with the intended supplier of the new system broke down, the A\&L manager, supported by the board of directors, dominated the content of the project. The office technology project was placed out of sight of the user organization. The goal was to implement a new, more stable and faster millennium proof platform with user applications replaced 'one-on-one'. The board of directors and the A\&L manager were concerned about the continuity of the business, and therefore did not give permission for extra improvements for users of a new system, as the first priority was that the business could function 
after the start of the new millennium. This reflects the dominance of performance contribution issues.

Human issues came into play when it was decided to opt for a two-screen version of the new user interface, instead of a one-screen version. Users reasoned from their working conditions' point of view, and made this demand as the two-screen version better suited to their preferred way of working. This is almost the only attention that was given to the user in this part of the "Better" project. When finally testing started, the system as delivered seemed to be a total failure. The users involved in the tests could hardly work with it as the system contained so many errors from their viewpoint. From that moment on, user applications became the center of the "Better" project. Especially the steering committee, and to an extent the project team first, then realized the importance of the user applications to the performance of the organization. They restarted the development stage, in order to improve the system in such a way that users could better carry out their administration tasks.

The way the project continued in this second development stage indicates an emphasis on human issues by the project team, IT developers and users. The basis however is still 'one-on-one', indicating the ongoing influence of performance contribution issues. The steering committee and the project team were concerned about the continuity of the organization and thus did not allow adjusting really new applications.

In conclusion, the management of the "Better" project contributed primarily by emphasizing performance contribution issues. Only to a moderate extent, and only by coincidence, did the management put emphasis on human issues. Organizational environment issues were not explicitly emphasized.

\section{IT experts' contribution}

Initially in the "Better" project two groups of IT experts were involved, an internal group of IT experts and an external group of IT experts. Later on, the project manager, who was the former manager for Automation and Logistics, was left as the sole IT expert. In practice, both the internal and external IT experts emphasized performance contribution issues, as they agreed upon replacing the systems' functionalities 'one-on-one' and ignoring the users' side of the system. The project leader from ' $V$-soft' commented that she found human issues important, and that it is even her basic philosophy to stress the user side of the technology. However, the circumstances at unit $\mathrm{C}$ pressed her to act otherwise. Later on, system developers had to describe the user applications directly from the screens, which allowed users to become involved and to stress their specific needs to a certain extent. This indicates attention to human issues.

Overall, initially, IT experts' contributions consisted of stressing performance contribution issues. Later, after a complete failure in the testing, they put more stress on human issues. 
In Table 6.1 we gave some attention to the extent to which users were involved in the "Better" project. Now we take a closer look at this aspect of the "Better" project. Table 6.2 shows the extent to which users were involved at each project stage.

\begin{tabular}{|l|l|l|l|l|l|l|l|l|}
\hline Stage of the Better project & $\mathbf{2}$ & $\mathbf{3}$ & $\mathbf{4}$ & $\mathbf{5}$ & $\mathbf{6}$ \\
\hline Initial decision making & $\mathrm{x}$ & & & & & \\
\hline Requirements analysis & & $\mathrm{x}$ & & & & \\
\hline Functional design/Technical design & & $\mathrm{x}$ & & & & \\
\hline Technical realization & $\mathrm{x}$ & & & & & \\
\hline Testing & & & $\mathrm{x}$ & & & \\
\hline Functional design/Technical design & & & & $\mathrm{x}$ & & \\
\hline Technical realization & $\mathrm{x}$ & & & & & \\
\hline Testing & & & $\mathrm{x}$ & & & \\
\hline Implementation & & $\mathrm{x}$ & & & & \\
\hline
\end{tabular}

$1=$ no or minimal information, 2 = information, $3=$ opportunity to give advice, $4=$ advice taken into consideration, 5 = joint decision-making, 6 complete control.

\section{Table 6.2 User involvement at each stage of the "Better" project}

From Table 6.2 we can see that users were poorly involved in the "Better" project as first planned. Users were represented by a member in the project team, but as the user applications were intended to be left to one side in the project (the old system's functionalities would be copied 'one-on-one'), users were not really expected to express any demands. After the complete failure of the first test, and the enormous number of errors (around 1500!) in the new system, the development process had to start all over again. From this moment on, users had a more prominent role.

\subsubsection{The clarity of the spirit}

The spirit of the new system ("Better") can be characterized as: better and more comfortable administration. Figure 6.2 visualizes this spirit, and 'deconstructs' it into some of the main structures. 


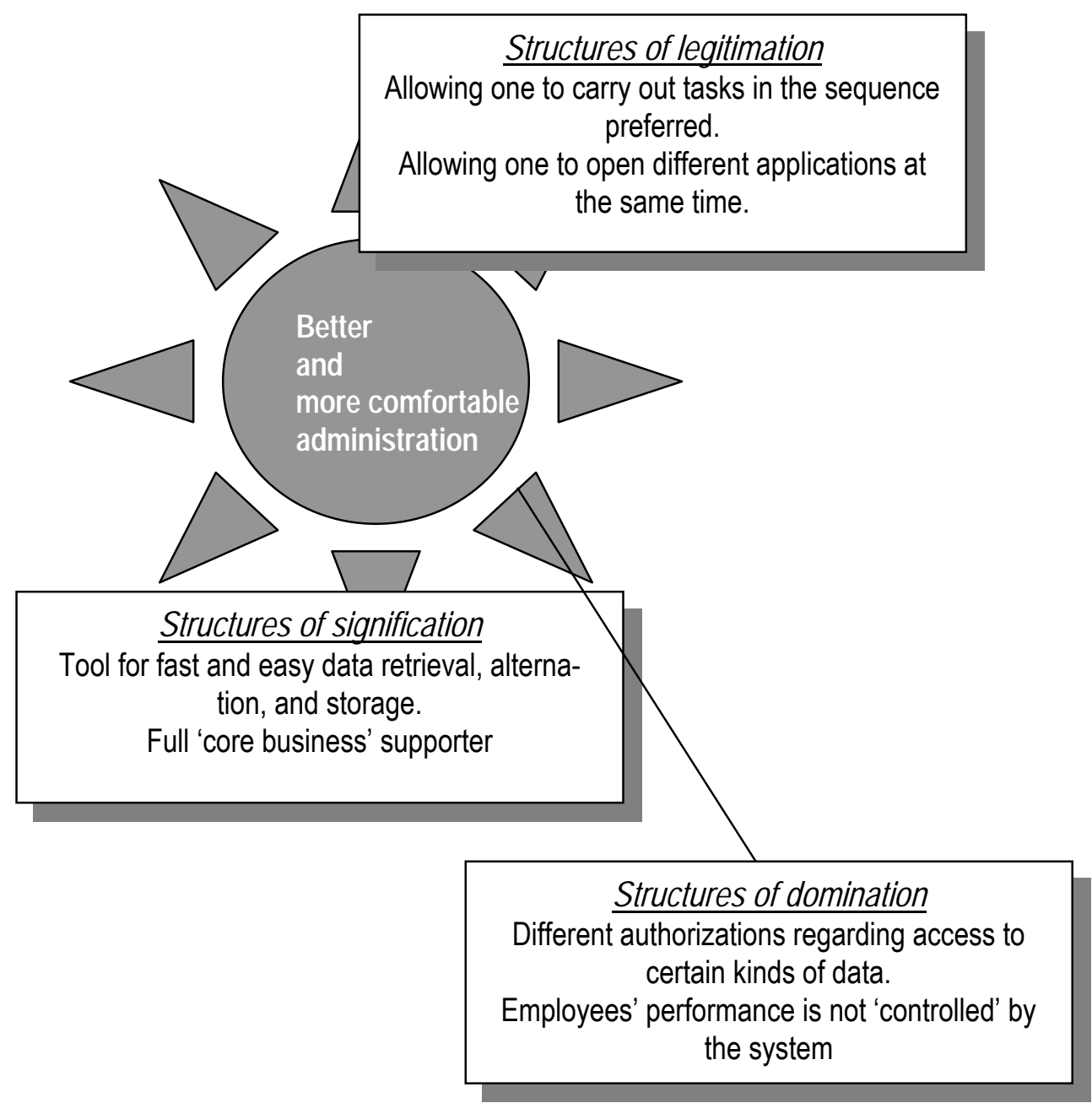

\section{Figure 6.1 The spirit of "Better" 'deconstructed' into examples of its main structures}

The new system's spirit together with "Better's" technical features concern the potential of the structures offered to users. These technical features of "Better", to 'realize' the system's spirit, can be typified as follows: 


\begin{tabular}{|l|l|l|}
\hline Criteria & Description & Qualification \\
restrictiveness & $\begin{array}{l}\text { The new system is more advanced than the old system. } \\
\text { In the new system, users can make choices about the } \\
\text { 'route' to take through the system and to organize their } \\
\text { work themselves. The system does not 'force' users to } \\
\text { follow a given screen sequence. }\end{array}$ & Moderate \\
\hline $\begin{array}{l}\text { Level of } \\
\text { sophistication }\end{array}$ & $\begin{array}{l}\text { "Better" contains only basic features, useful for the basic } \\
\text { aspects of unit C's primary process. The system does } \\
\text { not contain 'fancy' or 'nice to have' features, for example } \\
\text { multi media features. However, the windows-like } \\
\text { screens offered users better support in doing their work }\end{array}$ & $\begin{array}{l}\text { Low to } \\
\text { moderate }\end{array}$ \\
\hline $\begin{array}{l}\text { Degree of } \\
\text { comprehensiv } \\
\text { eness }\end{array}$ & $\begin{array}{l}\text { In comparison with the old system, "Better" was more } \\
\text { comprehensive. Users had several search options, they } \\
\text { could look up several types of basic information about } \\
\text { clients, and the new system includes a feature to couple } \\
\text { correspondence to a client file automatically. }\end{array}$ & $\begin{array}{l}\text { Low to } \\
\text { moderate }\end{array}$ \\
\hline
\end{tabular}

\section{Table 6.3 Typification of "Better's" technical features}

The spirit of the new system seemed quite clear to the employees of unit C. They were quite well able to appropriate the new potential of structures as soon as these were offered. They did not appear to be in a state of confusion very much and they knew how to appropriate the system. This can be seen as a result of the unintendedly high extent of user involvement after the initial tests failed. As the user applications had to be mapped straight from the screens in use, system developers and users interacted with each other intensively, and the project became to some extent an ongoing test. In this way, employees were able to contribute to the 'creation' of the spirit of "Better" in a direct way.

\subsubsection{Appropriation of "Better"}

The implementation of "Better" went technically as planned. That user applications were copied 'one-on-one' made it easier for users to rapidly appropriate the new systems' potential of structures. However, this was not completely unproblematic for all users. Some were not able to appropriate "Better" due to a lack of some technical features [missing screens]. System developers solved these problems at the institutionalized use stage.

The aspect during this stage that disappointed users most was the new system's performance. Users were somewhat prepared for this before the system was offered to them, as during the tests the performance had been an ongoing concern. But in this stage, when it was decided to implement the system, users again put emphasis on the quality of their work conditions, and expressed their dissatisfaction with the new system's low performance that made appropriation of the system in line with its spirit difficult. 
By December 1999 employees were working quite unproblematically with "Better". They were used to the changes that the implementation of the new system had brought about. The old system was character-based (with separate screens for each type of data processing), whereas the new system was windows-based (with only two screens for data processing; one for data entry, mutation and retrieval; and one for data consultation). In general employees experienced the new system, with its graphical interface, as pleasant and convenient to work with. They were able to work on more than one application at a time, they had more options for looking up data, could enter and retrieve data more easily (for example, entering a new insurance policy took less time than with the old system as employees did not have to go through several separate screens. Employees got used to the 'busy' screens and the small font-type. The only thing that still was unsatisfactory was the systems' performance. Employees found the new system quite slow, which resulted in some frustration and a slow task performance. Employees experienced the high response time as unpleasant although the number of breakdowns in comparison with the old system had decreased considerably. Systems experts did not seem to be able to solve the 'performance' problem. Finally, the remaining option was to replace the PCs by faster types. The management team decided to start a test with new, faster, PCs among a small group of employees. This showed the solution to be viable and the systems' performance increased to a satisfactory level.

In the table below the way users appropriated "Better" is described for each dimension: 


\begin{tabular}{|c|c|}
\hline $\begin{array}{l}\text { Aspect of } \\
\text { appropriation }\end{array}$ & Description \\
\hline $\begin{array}{l}\text { Appropriation } \\
\text { moves = high }\end{array}$ & $\begin{array}{l}\text { Users' level of appropriation moves in Unit } C \text { was quite high. The system } \\
\text { was a necessary tool for carrying out the daily tasks so users had to } \\
\text { work with the system's technical features. }\end{array}$ \\
\hline $\begin{array}{l}\text { Faithfulness of } \\
\text { appropriation = } \\
\text { moderate }\end{array}$ & $\begin{array}{l}\text { Although the system response times were improved in the ongoing use } \\
\text { stage, for some users (for whom new PCs had not yet been installed) it } \\
\text { was still not easy to have the feeling that users could work in } \\
\text { accordance with "Better's" spirit. Some users were unsure what to think } \\
\text { about the new system, especially because of the low response times. }\end{array}$ \\
\hline $\begin{array}{l}\text { Attitude towards } \\
\text { "Better" } \\
\text { (perceived } \\
\text { usefulness) = } \\
\text { moderate to } \\
\text { high }\end{array}$ & $\begin{array}{l}\text { Users' perception of the usefulness was very much influenced by } \\
\text { "Better's" bad performance in comparison with the old system. }\end{array}$ \\
\hline $\begin{array}{l}\text { Attitude towards } \\
\text { the "Better" } \\
\text { (perceive ease of } \\
\text { use) = moderate } \\
\text { to high }\end{array}$ & $\begin{array}{l}\text { The perceived ease of use gets the same assessment as the perceived } \\
\text { usefulness; the system's performance made users judge the new } \\
\text { system as only moderately to very easy to use. }\end{array}$ \\
\hline $\begin{array}{l}\text { Task oriented use } \\
=\text { high }\end{array}$ & $\begin{array}{l}\text { As a number of the users had participated in several tests of "Better", the } \\
\text { spirit of the system was already quite familiar when the system was } \\
\text { finally implemented. Therefore users were able to rapidly appropriate } \\
\text { the system in a task oriented way. However, the system did not leave } \\
\text { many alternatives than to use its features in this way. They were not } \\
\text { very comprehensive and sophisticated. }\end{array}$ \\
\hline $\begin{array}{l}\text { Explorative use }= \\
\text { low }\end{array}$ & $\begin{array}{l}\text { Although "Better" was in fact completely new, the basis of the system } \\
\text { was quite similar to the old system. Explorative use in the ongoing use } \\
\text { stage was low overall. }\end{array}$ \\
\hline $\begin{array}{l}\text { Consensus } \\
\text { among users on } \\
\text { appropriation = } \\
\text { moderate }\end{array}$ & $\begin{array}{l}\text { In the ongoing use stage, for some users, the system's performance had } \\
\text { improved, because of the new PCs. This was announced as something } \\
\text { that was going to happen for all users. However, as a result, there were } \\
\text { differences in the experienced consensus about how to work with the } \\
\text { new system features. }\end{array}$ \\
\hline
\end{tabular}

Table 6.4 The way users' appropriate "Better" in the ongoing use stage

Taking note of the descriptions in Table 6.4 it can be said that, in the ongoing use stage, users within unit $C$ made appropriation moves towards "Better" to quite a high extent. A large number of these moves were task oriented. However, users experienced that they were still only moderately able to appropriate the system in line with the spirit. Users said that they found the new system moderately to highly useful, and easy to use. The system's features did not require much time for further exploration in the ongoing use stage, and the 
level of consensus about how to appropriate the system's features was moderate.

\subsubsection{The context of appropriation of "Better"}

The implementation of "Better" was characterized by the following contextual factors (Table 6.5):

\begin{tabular}{|c|c|}
\hline Characteristic & Description \\
\hline $\begin{array}{l}\text { Level of change in } \\
\text { the internal } \\
\text { organization }\end{array}$ & $\begin{array}{l}\text { At the start of the "Better" project the initiators of the project (A\&L } \\
\text { manager, board of directors) had planned not to bring about any } \\
\text { changes in the work environment of users. However, unintendedly, the } \\
\text { project had to take into consideration human issues to a certain extent, } \\
\text { and this showed that not taking into account the user applications was } \\
\text { a major mistake. They seemed to be crucial for the success of the } \\
\text { project. However, from the users' perspective, the "Better" project was } \\
\text { mainly 'technically' oriented, changes in organizational design were not } \\
\text { considered. }\end{array}$ \\
\hline $\begin{array}{l}\text { Level of work } \\
\text { autonomy after the } \\
\text { implementation }\end{array}$ & $\begin{array}{l}\text { The existing organization design and job design were intended to be } \\
\text { left aside in the project. After implementation, the primary process was } \\
\text { still was made up of a number of steps, each of which was allocated to } \\
\text { a group of users. In general, users perceived the level of autonomy as } \\
\text { moderate to high, but differences existed. }\end{array}$ \\
\hline $\begin{array}{l}\text { Satisfaction with } \\
\text { implementation } \\
\text { process }\end{array}$ & $\begin{array}{l}\text { The final implementation of the new system was technically } \\
\text { unproblematical. However, users had waited for such a long time } \\
\text { before the system was implemented that they had lost some } \\
\text { confidence. Having helped to repeatedly test pieces of the new system, } \\
\text { led to user disappointment about what to expect. Users were } \\
\text { moderately satisfied with the implementation process. }\end{array}$ \\
\hline $\begin{array}{l}\text { Satisfaction about } \\
\text { reason for new } \\
\text { system development }\end{array}$ & $\begin{array}{l}\text { Initially, users in general supported the development of the new } \\
\text { system, because the performance of the old system (instability and low } \\
\text { response time) was experienced as very unpleasant. This improved } \\
\text { during the duration of the "Better" project. Thus, the need for a new } \\
\text { system from the users' perspective decreased. When the new system } \\
\text { was found to be even slower than the improved old system, users were } \\
\text { disappointed. In general, users were happy with the new interfaces. In } \\
\text { the ongoing use stage, the problems with the speed of the new system } \\
\text { seemed to be finally solved, but still it was questioned whether a new } \\
\text { system had been necessary. }\end{array}$ \\
\hline $\begin{array}{l}\text { Satisfaction with } \\
\text { support when having } \\
\text { problems during the } \\
\text { ongoing use stage }\end{array}$ & $\begin{array}{l}\text { In the ongoing use stage the technical problems with the new system } \\
\text { were solved bit by bit. Users experienced a moderate level of support. } \\
\text { The performance problems were experienced as being solved quite } \\
\text { slowly. }\end{array}$ \\
\hline
\end{tabular}

Table 6.5 The "Better" project context characteristics 
From the descriptions in Table 6.5 we conclude that the level of change in their work environment accompanying the implementation of the "Better" project was low. The level of work autonomy after the implementation was moderate to high. Users were moderately positive about the reasons for developing and implementing the new system, and were moderately satisfied with the implementation process. Finally, users' satisfaction with the support received when having problems with "Better" was moderate to high.

\subsubsection{Project outcomes}

The outcomes of the "Better" project in terms of work process effectiveness, anticipated and unanticipated changes, and project costs are listed in Table 6.6.

\begin{tabular}{|l|l|}
\hline $\begin{array}{l}\text { Outcome } \\
\text { Work process } \\
\text { effectiveness } \\
=\text { moderate }\end{array}$ & $\begin{array}{l}\text { Users experienced the work processes within unit C as moderately } \\
\text { effective in the ongoing use stage. The output of unit C was quite low. } \\
\text { The new system did not seem to contribute to improved work process } \\
\text { effectiveness. }\end{array}$ \\
\hline $\begin{array}{l}\text { Unanticipated } \\
\text { changes } \\
=\text { moderate to } \\
\text { high }\end{array}$ & $\begin{array}{l}\text { The implementation of "Better" brought about a moderate level of } \\
\text { unanticipated changes. In our perception, it was not anticipated that the } \\
\text { user applications would actually determine the project's result. Initially } \\
\text { these were considered as 'outside the scope', but by the end they } \\
\text { seemed crucial. It was not anticipated what the impact of the change } \\
\text { from character-based user applications to windows-like user applications } \\
\text { would be. This impact seemed to be high. Furthermore, the new } \\
\text { system's technical performance was worse than the improved version of } \\
\text { the original system. This brought about change in the way users had to } \\
\text { do their work. Until the solution of replacing the PCs was implemented, } \\
\text { users had to be satisfied with the long response times of the new } \\
\text { system. }\end{array}$ \\
\hline $\begin{array}{l}\text { Anticipated } \\
\text { changes } \\
=\text { low }\end{array}$ & $\begin{array}{l}\text { The impression is that almost everything in the "Better" project was not } \\
\text { anticipated. }\end{array}$ \\
\hline $\begin{array}{l}\text { Project costs } \\
=\text { budget far } \\
\text { exceeded }\end{array}$ & $\begin{array}{l}\text { Official figures are not available but from various sources it is concluded } \\
\text { that the project cost much more than planned. The project manager had } \\
\text { to ask for extra budget more than once. }\end{array}$ \\
\hline
\end{tabular}

\section{Table 6.6 Project outcomes}

So far, we have described the "Better" project within Unit C, in the next section the relationships between the main variables are assessed. 


\subsection{Testing the hypotheses}

\subsubsection{Hypothesis 1}

We used a questionnaire to test the three main hypotheses, as in the previous two case studies. The first hypothesis concerns the influence of user involvement on the clarity of spirit. In previous subsections we have already concluded that users were initially only slightly involved, but after the first test resulted in a complete failure, users got a more prominent role (albeit unintendedly). With this knowledge, it is interesting to see whether users who were more involved found the new system's spirit clearer than users who were less involved.

The extent to which users have a say in the development and implementation of office technology is positively related to the clarity of the spirit to users.

The results of the analysis are shown in the following figure 6.2:

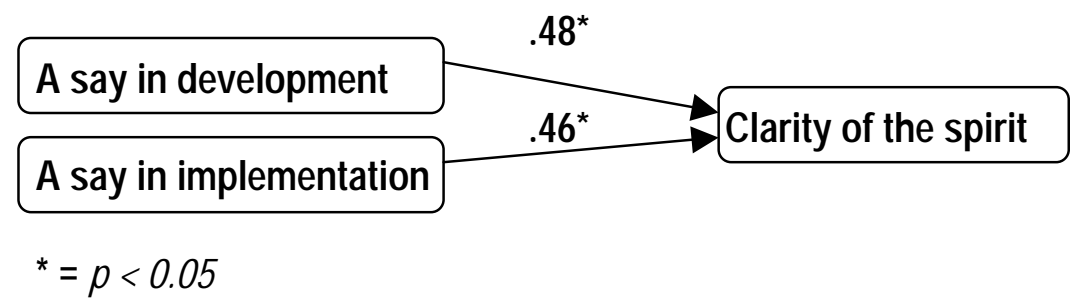

Figure 6.2 The relationship between having a say in the development and the implementation and the clarity of spirit $(\mathrm{N}=29)$

Figure 6.2 shows that there is a significantly positive relationship between the level of involvement in the project and the clarity of the system's spirit. In other words, within the "Better" project, users who were involved found the spirit clearer than users who were not involved. This means that our first hypothesis is confirmed in this situation.

\subsubsection{Hypothesis 2}

Theoretically we supposed that the clarity of the spirit to users, influences the level of appropriation of an office technology. Is this true for the "Better" project? 
The clarity of the spirit to users is positively related to the level of appropriation

The analysis of the questionnaire responses resulted in the relationships shown in Figure 6.3.

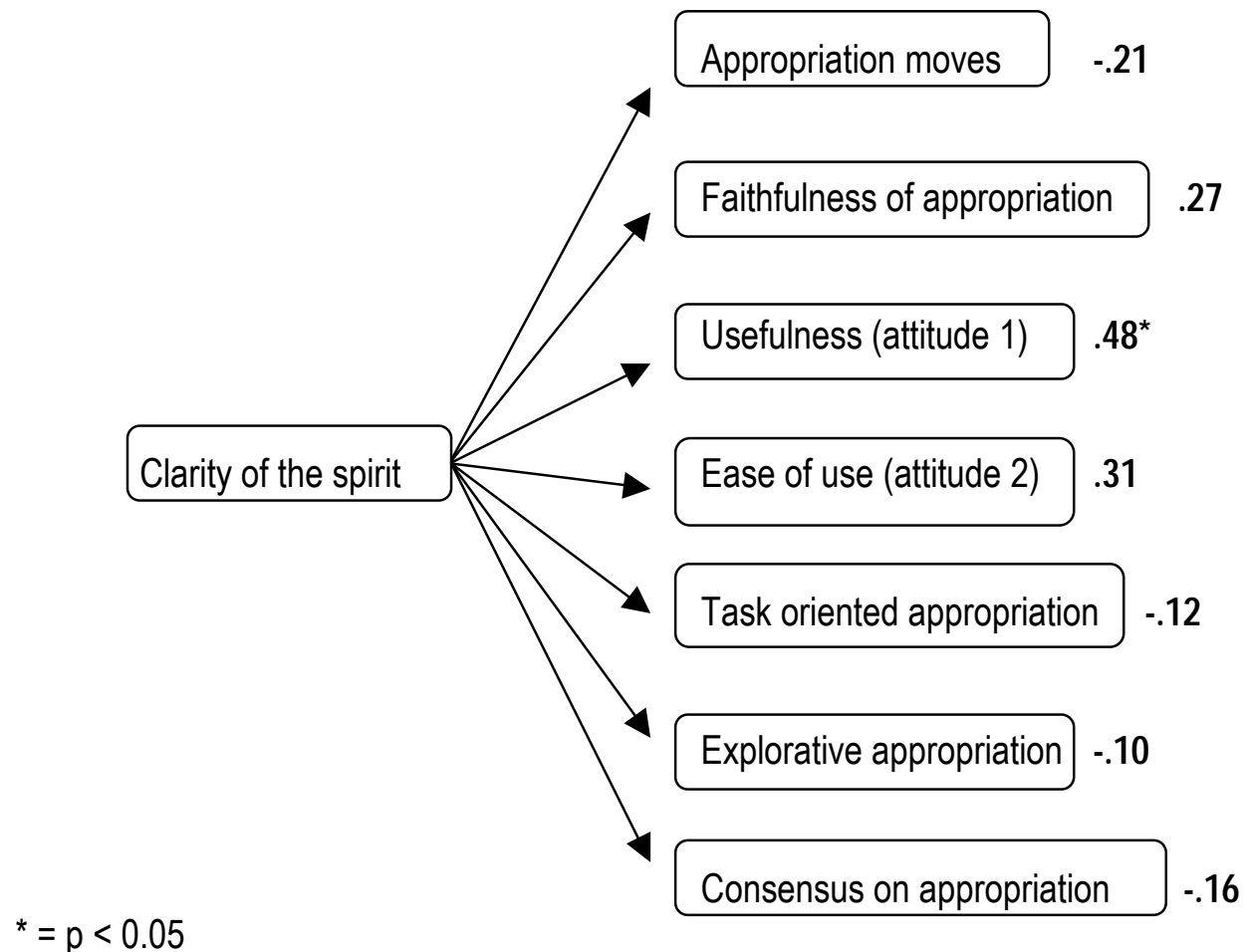

Figure 6.3 The relationship between the clarity of the spirit and the level of appropriation $(\mathrm{N}=29)$

Regarding the results from unit $C$, presented in Figure 6.3, we can conclude that the extent to which users having a clear understanding of the spirit of "Better" is only significantly, positively related to the perceived usefulness of the system. This is in line with our general theoretical expectation, as is the fact that the clarity of spirit is negatively related to the level of explorative use. Furthermore, the clarity of the spirit is moderately positively related to faithful appropriation and perceived ease of use, although not statistically significantly.

The clarity of spirit is not positively related to the level of appropriation moves, the level of task oriented use, and the level of consensus. This is not in line with what was expected. In our research model we proposed a number of intervening contextual factors in the relationship between the clarity of spirit and the level of appropriation. These are; the level of change in the internal organization that accompanied the implementation, the level of work autonomy, 
the level of satisfaction with the implementation process, the level of satisfaction with the reasons to implement the system, and the level of support during appropriation in the ongoing use stage. In our view, in the "Better" project, a reasonable explanation is the moderate to high level of work autonomy after the implementation of the new system. In other words the users have quite some space to organize their daily work in the way they prefer. In terms of appropriating the system this can imply that users have more space to choose whether to appropriate the system's features or not. In other words, users have some space to look for alternatives, instead of using the system. Furthermore, from the project description, we learned that users in general were poorly satisfied with the reasons for implementing "Better". This perhaps implies that users can find the spirit clear, but intentionally not appropriate the system in line with this spirit. In our opinion, this can help explain the disappointing results (in terms of confirming hypothesis 2).

Overall, the second hypothesis is not convincingly confirmed.

\subsubsection{Hypothesis 3}

Our third hypothesis supposed theoretically that the level of appropriation is positively related to the level of work process effectiveness. In this case study we will discover whether this is true for the "Better" project in unit C. The third hypothesis was formulated as follows:

The level of office technology appropriation is positively related with the level of work process effectiveness 
From the analysis of the questionnaire responses the relationships shown in Figure 6.4 were established.

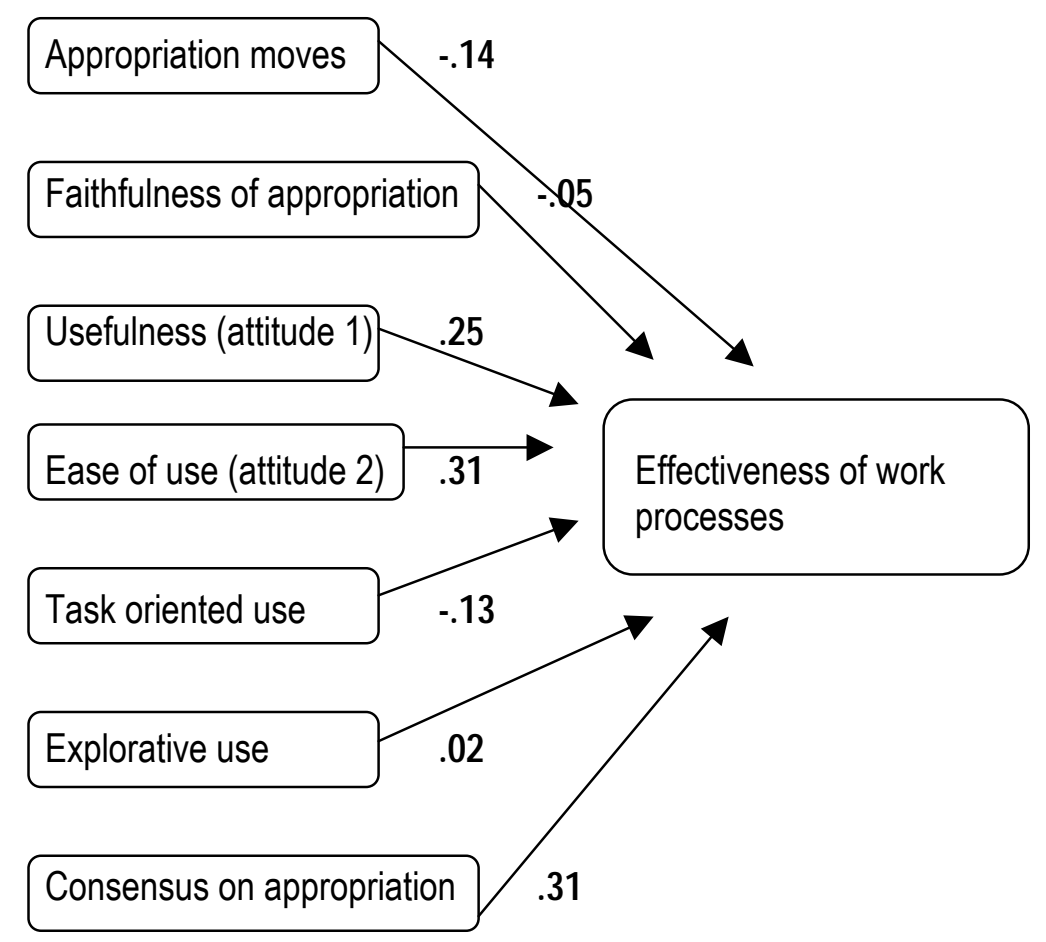

Figure 6.4 The relationship between the level of appropriation and work process effectiveness $(\mathrm{N}=29)$

We observe that there is hardly any relationship between the levels of appropriation moves, faithful appropriation, task-oriented use, explorative use and the level of work process effectiveness. This is contrary to our theoretical expectations. In our research model two intervening contextual factors in the relationship between appropriation and work process effectiveness are included, which are not tested statistically for each case study, but only in chapter 8 (cross-case analysis). These are the level of change in the internal organizational environment that accompanied the implementation of the office technology, and the level of work autonomy of users. At present, we can only guess which of these factors intervene most strongly. In our view, based on experiences at unit $\mathrm{C}$, both of these factors could play a role in this case study. As commented earlier, users in unit $\mathrm{C}$ had significant autonomy. They did not experience that they were really stuck with the new system, and experienced that they could choose alternatives instead of using "Better". This may explain why appropriation of the system does not really make a difference in the level of 
work process effectiveness. Furthermore, the "Better" project was not accompanied by any anticipated organizational changes. Perhaps if this would have been the case, the use of the new system would have had a much larger impact on work process effectiveness.

Perceived usefulness, perceived ease of use, and consensus on appropriation are not positively related to a significant level to work process effectiveness, which is also not in line with our expectations. However, the correlations are positive which might indicate that, within the context of unit $\mathrm{C}$, the perceived usefulness and ease of use of "Better", and the level of consensus about how to appropriate the system are aspects that offer opportunities to influence work process effectiveness positively.

In conclusion, based upon the lack of significant correlations, we have to conclude that our third hypothesis is not convincingly confirmed at unit $\mathrm{C}$.

\subsection{Summary of findings}

So far our third case study, which concerned an office technology project "Better" to introduce a health insurance administration system. The office technology project in unit $\mathrm{C}$ can be characterized as having two parts: the first part until the first unsuccessful test, and the second part from this test until the definitive implementation. Overall, we find that, in the project, a hard approach was used to system development and implementation, but that during the project a switch was made towards a soft approach, however unintended! In the project, the management and IT experts contributed predominantly by stressing performance contribution issues. IT experts were the first to stress human issues, after the first test failed.

Users were poorly involved in the first part of the project, but this changed after the test. The project had to start over again with user applications placed central in the project. From this moment on, users were more involved through a small group of representatives. In general, users experienced that they had been only slightly involved.

The new system's spirit was described as better and more comfortable administration. The general objectives and procedures behind the technical features offered to users were to improve the administration process and to support users. When the system was implemented, the spirit of the new system seemed quite clear to the employees of unit $\mathrm{C}$. This can be explained from the unintendedly high extent of user involvement after the first tests failed completely. In the ongoing use stage, users did not appropriate the new system's technical features to a convincingly high level. This was due, in a large part, to the poor performance of the new system in comparison with the old system. In the ongoing use stage therefore we observed one main unanticipated consequence: users' level of output was low. Users did not appropriate the 
system in line with the spirit of the system, in particular because they experienced that features could not be appropriated as intended, due to poor performance.

The "Better" project did not bring about any significant anticipated changes in the internal organizational environment of users. They experienced a moderate to high level of work autonomy after the implementation of the new system. The implementation process was moderately satisfactory in users' views, but users still questioned whether a new system was necessary, as its performance was poor. The level of support from the organization with occurring problems when using the new system was moderate.

The new system did not really contribute to the work process effectiveness in the ongoing use stage. It resulted in a high level of unanticipated changes. In fact, the whole project outcome was not what was anticipated! The "Better" project also well exceeded its budget.

In order to find out how to improve office technology projects, which is our overall research objective, we tested our three hypotheses. We found that within the "Better" project, users who were more involved in the office technology project found the spirit of the new system clearer than those who were not involved. This suggests that involving users in office technology development and implementation contributes to the clarity of a new system's spirit to users. In this project, involving users right from the start might have prevented that development of a new system that initially went so completely wrong.

The extent to which users found the spirit clear was not convincingly positively related to the level of appropriation of "Better". We believe that the "Better" project could have benefited from implementing a system that would have met users' demands to an overall higher extent than "Better". If users had agreed upon the intentions of the office technology to a higher degree, they might have been more willing to let these intentions arise while using the technology.

The extent to which users appropriated the new system was not convincingly, positively related to work process effectiveness. In other words, using the system intensively, in line with its spirit did not contribute convincingly to work process effectiveness. We believe that this can be explained by the low level of anticipated organizational change in the "Better" project, and the quite high level of users' work autonomy. Implementation of the new system could have more successful if it had been combined with changes in the internal organization. 


\section{Seven}

\section{An electronic calendar management system project}

\subsection{Introduction}

Our fourth and final case study concerns an office technology project in a faculty of a university. The project, which dealt with the choice, implementation and use of an electronic calendar management system, started around the beginning of 1999 and lasted about 12 months. This chapter's structure is similar to the former three chapters: section 7.2 describes the organizational context in which the project took place; section 7.3 contains the description of the project in terms of the research model. In section 7.4 we test our three main hypotheses and section 7.5 summarizes and reflects on the findings.

\subsection{The organizational context}

The unit in which the new office technology, an electronic calendar management system, has been implemented is a university faculty in the east of the Netherlands. For ease we will call this unit, unit $\mathrm{D}$. The unit's primary process is education and scientific research.

The organization consists of five, so-called chairs, which are each led by a professor. The head of the faculty is the dean, who is responsible for the scientific policy as well as for business matters. For the business side of the faculty the dean is supported by a manager. This is also the case for his responsibility regarding education.

Together with the two managers, the dean forms the daily management team of the faculty. Overall, the faculty is managed by a faculty management team consisting of all the full time professors plus the daily management team. The organizational structure can be typified as a matrix. The faculty staff can be divided into a group of scientific members and a group of facilitating members. To this facilitating staff can be added a group of secretaries. The office technology project that is the subject of this chapter is concerned with this group of secretaries.

The typification of the office

As already mentioned, it is this group of secretaries that is our prime interest. In terms of the taxonomy in chapter one the office in our unit of study 
can be typified as a procedural office. The secretaries together form a unit with the primary task of processing information for the staff members they support. The secretaries are a group of interrelated individuals that operate word processors, copiers, terminals etc. to carry out their tasks. The tasks of the secretaries include: receiving and sending mail, correspondence, enhancing texts for the scientific staff and, last but not least, managing the agenda of the chair, in particular that of the professor or manager. In general, managing the agenda takes approximately $30 \%$ of the time of the secretaries.

\section{Characteristics of the employees}

The group of employees that are the subject of our study can be characterized as follows (based upon a response rate of 100\%): 100\% are female; the average age is 33.3 ; the average time the employees have worked at unit $D$ is 3.7 years; the highest education of $65.5 \%$ of the employees is high school (HAVO, VWO, MBO).

\subsection{The project "Electronic calendar management"}

\subsubsection{Methodology}

For studying the "Electronic calendar management" project (from now on abbreviated to: ECM project) we used conversational interviews, documents, observations, and questionnaires. The conversational interviews were held with: the dean, the business manager, the chairman of the office automation committee, the system manager (also the project leader), a full time professor, and six secretaries (most of them twice). We also participated in a meeting of the office automation committee. In addition we studied the system in use by the employees of the faculty. Finally, we asked employees who use the electronic calendar to complete a questionnaire.

In the rest of this chapter the terms employees, secretaries, and users are mutually exchangeable.

\subsubsection{Project characteristics}

Before he started his job at this faculty, the faculty's business manager functioned as the manager of another faculty. In his former job he was used to electronic calendar management and was surprised that his new faculty did not have such a system. The business manager expressed his discontent about this and observed that one of the obstacles to a higher level of office technology use in this faculty was the fact that there was more than one computer platform in use, which made the implementation of office technologies more difficult. Scientific staff members differed in their preferences for a particular platform. 
The manager was somewhat surprised about the low level of office technology use in his faculty, especially since the faculty carried out scientific research in the field of computer science and educated students in this field. The dean of the faculty agreed with him that the faculty's level of office technologies was too low. Therefore in the last quarter of 1998 the daily management team decided to set up a special committee in order to advise the daily management team on how to apply office technologies in the faculty. This office technology committee consisted of the business manager, the head of the laboratory, the system manager, and three scientific staff members. One of these scientific staff members was appointed as chairman as he already had participated in another committee related to this new one and was considered to be a specialist on office technology. Besides this, it was hoped that if a scientific staff member functioned as chairman, the acceptance of new technologies among the scientific staff might increase.

The committee was given the assignment to investigate what types of office technologies could be useful for the faculty and what specific choices to make. One of the committee's advices was to implement an electronic calendaring system. The system manager developed a plan of approach with the advice to buy an existing system of the type $\mathrm{SM}^{8}$. The grounds for this advice was that the committee in general expected the process of calendar management (setting up appointments between members of the faculty's staff to be more efficient and more specifically to increase the service level of the secretaries towards the staff members. With an electronic calendar management system users should be able to plan meetings between employees in the group of users, secretaries should be able to manage their professor's or manager's diaries, schedules also had to be able to be synchronized with hand-held computers, and users should be able to look in each others' personal folders and collective folders should be created.

\section{Start of the project}

The daily management team agreed to the committee's advice to implement an electronic calendar management system of type SM Inlook. The committee received the assignment to lead this implementation and therefore can be considered as a project team. The system manager, a member of this team, became the project leader. He had the responsibility for the operational side of the implementation. The project team's plan was to implement an electronic method of calendar management across the whole faculty, involving all the employees. The office technology committee was aware of the fact that scientific staff members would resist this if they were forced. Therefore the office technology committee decided to implement the electronic calendar

\footnotetext{
8 This is a fictitious name.
} 
management system only in the secretaries' offices and let other faculty members decide on a voluntary basis whether they would use an electronic calendar. It was expected that, after implementation at the secretaries' offices, the take up of the electronic calendar management system would spread rapidly.

Secretaries in general reacted uncomplainingly, although a few negative reactions were heard. The most specific reactions were the expectation that the use of an electronic calendar would involve an increase in computer-driven work, and with this the level of mouse use. One of the secretaries already had RSI complaints.

On the $18^{\text {th }}$ February 1999, the project leader organized an introductory training session for all secretaries. After this introductory training, he planned to technically install the new electronic calendaring system in the secretaries' offices.

The project leader installed the new electronic calendar management system one office at a time. This took a number of weeks, which meant that the system could not be used in its interconnected mode. A few months after implementation, the electronic calendar management system was a well-known phenomenon among the secretaries.

Table 7.1 presents the characteristics of the project from an office technology development and implementation methodological point of view.

\begin{tabular}{|l|l|}
\hline $\begin{array}{l}\text { Characteristics } \\
\text { Management } \\
\text { development } \\
\text { priorities = } \\
\text { technical } \\
\text { optimization }\end{array}$ & $\begin{array}{l}\text { From the project description we conclude that management's priorities in } \\
\text { starting the "ECM" project were to technically optimize the use of office } \\
\text { technologies in the organization. Unit D had to become more technologically } \\
\text { 'sophisticated'. It was also believed that an increase in office technology use } \\
\text { could improve organizational processes, for example calendar management. } \\
\text { Both aspects are labeled as technical optimization priorities. }\end{array}$ \\
$\begin{array}{l}\text { Furthermore, a reason for starting the "ECM"-project was that the current way } \\
\text { of calendar management was seen as very time-consuming, and for some } \\
\text { secretaries a quite unpleasant task. An electronic calendar could make it } \\
\text { easier although his was not the main driving force in our view. }\end{array}$ \\
\hline $\begin{array}{l}\text { Extent of user } \\
\text { participation = } \\
\text { Low }\end{array}$ & $\begin{array}{l}\text { In the "ECM" project users were hardly involved. It was assumed by the office } \\
\text { technology committee that the secretaries were not interested in being } \\
\text { involved. The secretaries lacked technical knowledge and so adequate } \\
\text { involvement would be difficult for them, or at least this was the view of the } \\
\text { committee. }\end{array}$ \\
\hline
\end{tabular}

Table 7.1 The characteristics of the development method of the "ECM" project (continued on the next page) 


\begin{tabular}{|c|c|}
\hline Characteristics & Description of 'ECM'-project \\
\hline $\begin{array}{l}\text { Approach to } \\
\text { problem } \\
\text { investigation = } \\
\text { Top down }\end{array}$ & $\begin{array}{l}\text { The "ECM" project was characterized by a top-down problem investigation. } \\
\text { The management, who initiated the project, seemed to believe that the main } \\
\text { problems, the low level of office automation and the low level of efficiency } \\
\text { and service, could be solved by technological solutions. By dividing it in sub- } \\
\text { problems, e.g. a calendar management problem, for each part a piece of } \\
\text { technology could be implemented for each problem solution. }\end{array}$ \\
\hline $\begin{array}{l}\text { Approach to } \\
\text { system modeling } \\
= \\
\text { predominantly } \\
\text { function } \\
\text { oriented }\end{array}$ & $\begin{array}{l}\text { The system modeling approach used in the "ECM" project was very implicit. A } \\
\text { real system model (system design) was not made, as it was assumed to be } \\
\text { unnecessary; the new system was bought as a package, which only had to } \\
\text { be customized by the system manager. Implicitly however, we observed the } \\
\text { system was modeled in terms of functions it had to accomplish to meet the } \\
\text { objectives. There is no evidence that the new system was modeled in terms } \\
\text { of a set of human processes in order to meet the system's objectives. }\end{array}$ \\
\hline $\begin{array}{l}\text { Control of } \\
\text { development } \\
\text { process = } \\
\text { Partly formal } \\
\text { and structured, } \\
\text { partly informal } \\
\text { and } \\
\text { unstructured. }\end{array}$ & $\begin{array}{l}\text { The "ECM" project was controlled partly in an informal and in some sense an } \\
\text { unstructured way, partly in a formal and structured way. The management did } \\
\text { not officially set up a project organization, but unofficially the parties involved } \\
\text { worked in line with generally accepted project management structures. For } \\
\text { example, the system manager was considered to be the project manager, } \\
\text { and within the office automation committee, time lines and budgets were set. }\end{array}$ \\
\hline $\begin{array}{l}\text { Project life cycle } \\
\text { time scale = } \\
\text { First long, then } \\
\text { later it switched } \\
\text { to a short life } \\
\text { cycle }\end{array}$ & $\begin{array}{l}\text { When the "ECM" project started, the system manager (and project leader) } \\
\text { had to customize the system, which can be considered as a system } \\
\text { development process. The basic idea was to complete the system first, } \\
\text { before implementing it throughout the organization. This reflects a long } \\
\text { project life cycle. However, in practice when the system was finally } \\
\text { implemented, which occurred later than initially planned, it had to be further } \\
\text { developed step by step. When the system was technically installed, users } \\
\text { could not make full use of it because a number of the functionalities were not } \\
\text { operational. These were established only later. Secretaries were informed } \\
\text { about newly available functionalities during information meetings with the } \\
\text { project leader. In these meetings secretaries could pass on information about } \\
\text { how they experienced the system's functionalities. This can be labeled as a } \\
\text { characteristic of a short project life cycle. }\end{array}$ \\
\hline
\end{tabular}

Table 7.1 The characteristics of the development method of the "ECM" project (continued on the next page) 
Basically the project can be characterized by the 'waterfall' model. The model $=$ Initially 'Waterfall', later on somewhat more evolutionary project leader was in charge and could do what he considered best to make the project a success. Observing the project process, the "ECM" project was implicitly divided into a separate development phase followed by an implementation phase. After implementation, the system development in fact continued, and additional functionalities were implemented in close contact with users. This indicates a 'switch over' to a more evolutionary project life cycle.

Table 7.1 The characteristics of the development method of the "ECM" project

Considering the description of the characteristics, we draw the conclusion that the "ECM" project had the characteristics of a hard approach until its implementation. After implementation, the project continued by implementing additional functionalities step by step, in close contact with users. This reflects a switch towards a softer approach.

\section{Management contribution}

Initially, unit D's business manager and the dean considered that the level of office technology was too low. Especially the business manager saw the current method of calendar management as time consuming and inefficient. The dean agreed with this, but was more reserved about the extent to which an electronic calendaring system could improve the situation. This reflects that the emphasis was put on performance contribution issues. The office technology committee's advice, to implement an electronic calendar management system, was grounded in the belief that the current calendar management could be improved upon. This also reflects an emphasis on performance contribution issues.

In conclusion, the management contributed predominantly by emphasizing performance contribution issues.

\section{IT experts' contribution}

The "ECM" project was supported by only one IT expert, the system manager, who had the position of project leader. He mainly stressed the aim of increasing efficiency. This reflects his emphasis on performance contribution issues. However, the system manager was also the one who expressed the view that the system had to be easy and convenient in use. He believed that only when a system is perceived as useful it will be accepted. We interpret this as an acknowledgement of human issues. 


\subsubsection{User involvement}

In Table 7.1 we gave a first indication of the extent to which users were involved in the "ECM" project and Table 7.2 gives a more detailed picture.

\begin{tabular}{|l|l|l|l|l|l|l|l|}
\hline Stage of the "ECM" project & $\mathbf{1}$ & $\mathbf{2}$ & $\mathbf{3}$ & $\mathbf{4}$ & $\mathbf{5}$ & $\mathbf{6}$ \\
\hline Initial decision making & $\mathrm{x}$ & & & & & \\
\hline Technical realization & $\mathrm{x}$ & & & & & \\
\hline Implementation & & $\mathrm{x}$ & & & & \\
\hline Dissemination/dispersion & & & & $\mathrm{x}$ & & \\
\hline
\end{tabular}

$1=$ no or minimal information, 2 = information, $3=$ opportunity to give advice, $4=$ advice taken into consideration, 5 = joint decision making, 6 complete control.

\section{Table 7.2 User involvement at each stage of the "ECM" project}

If we look at users' involvement during each stage, we conclude that users only played a prominent role after the implementation of the new system. From that moment on, as discussed earlier, the project leader organized information meetings for users in order to stimulate users to appropriate the new system's features, and to get feedback from users.

\subsubsection{Clarity of the spirit}

The spirit of the system as developed and implemented in unit $D$ is described in Figure 7.1. It also shows examples of the main structures that are promoted by this spirit. 


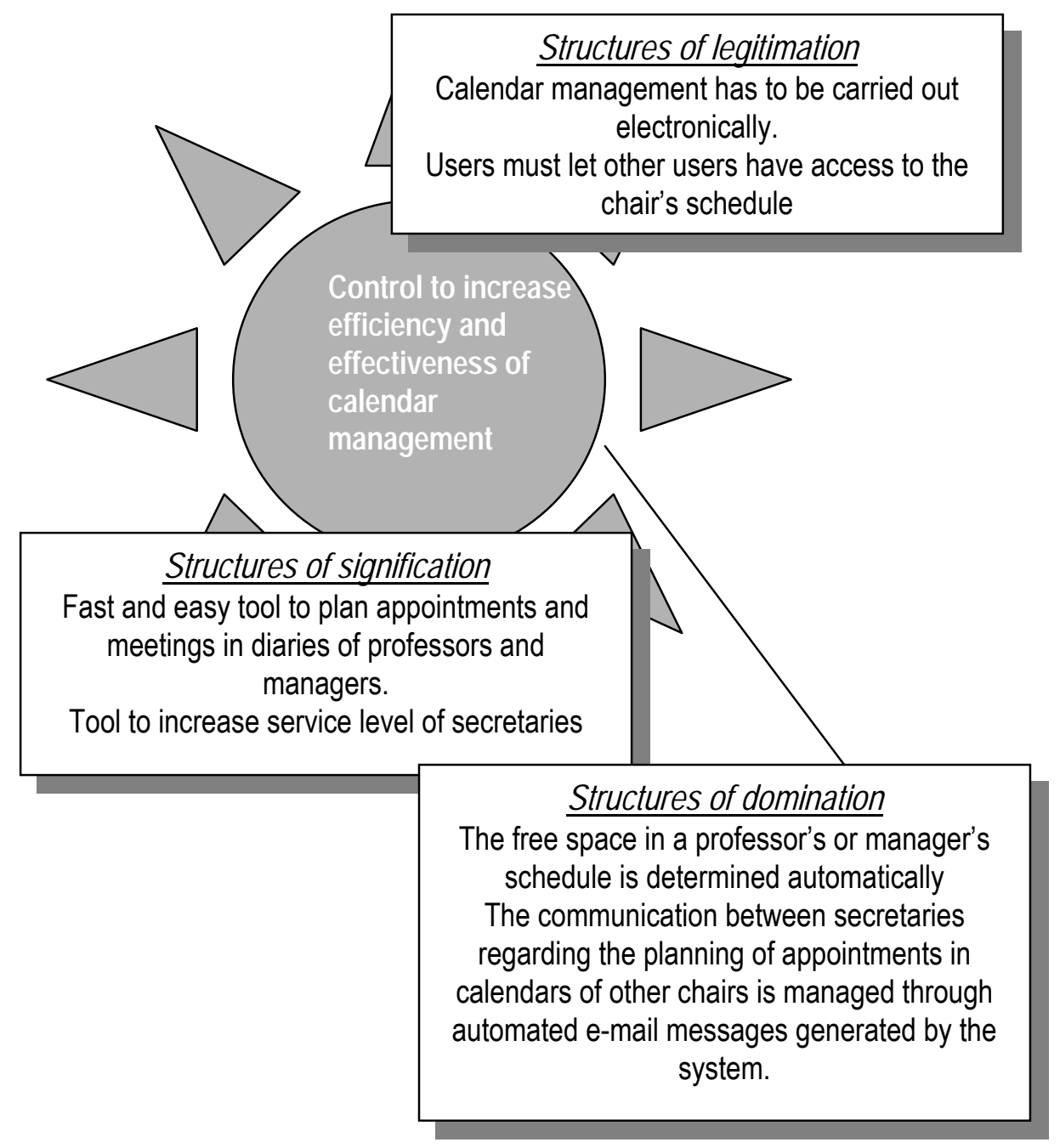

Figure 7.1 The spirit of the electronic calendar management system and examples of its main structures

Figure 7.1 shows that the spirit of the electronic calendar can be basically characterized as: control to increase efficiency and effectiveness of calendar management. We conclude that the electronic calendar was believed to be able to 'control' the way calendar management takes place within unit $D$. The paperbased calendar was assumed to be less efficient and less effective. By introducing a piece of technology that could 'control' the calendar management process it was expected that an increase in efficiency and effectiveness would be realized. This is further expressed in the following example: one of the aspects that was assumed to increase efficiency and effectiveness was that the new electronic agenda would enable secretaries to look in each other's 
electronic calendars through the creation of a corporate folder, and to place appointments in other chair's calendars. This implied that secretaries had to 'open' their calendar to others, and give other users the authority to place appointments in the calendar. In fact, the spirit of the technology encouraged secretaries to authorize other secretaries to place appointments in their chair's calendar.

When the electronic calendar first was implemented its technical features had the following characteristics:

\begin{tabular}{|l|l|l|}
\hline \multicolumn{1}{|c|}{ Criteria } & \multicolumn{1}{c|}{ Description } \\
\hline $\begin{array}{l}\text { Level of } \\
\text { restrictiveness }\end{array}$ & $\begin{array}{l}\text { The system gives secretaries a considerable number of } \\
\text { actions that they can take. It expresses quite some } \\
\text { 'freedom' for users to manage the calendar. }\end{array}$ & Low \\
\hline $\begin{array}{l}\text { Level of } \\
\text { sophistication }\end{array}$ & $\begin{array}{l}\text { Immediately after implementation the system contains } \\
\text { only features focussed on basic calendar management. } \\
\text { Features to communicate were not implemented, such } \\
\text { as e-mail for workgroups, and features to share folders. }\end{array}$ & Moderate \\
\hline $\begin{array}{l}\text { Degree of } \\
\text { comprehen- } \\
\text { siveness }\end{array}$ & $\begin{array}{l}\text { The system offers a considerable variety of features, } \\
\text { such as: it can automatically look for free space, it can } \\
\text { display different types of overviews, it contains a lot of } \\
\text { space to add extra notes. Regarding specific } \\
\text { appointments, it contains task management tools and } \\
\text { contact-management tools. }\end{array}$ & High \\
\hline
\end{tabular}

\section{Table 7.3 Typification of the electronic calendar's technical features}

The spirit of the new system seemed slightly unclear to the secretaries of unit $D$ when it was implemented. Secretaries could begin to replace their current paper diary by the electronic one. Only a small group of the secretaries did this, and they also kept their paper diaries. The faculty manager's secretary was the only one who clearly gave up the 'traditional' paper diary right from the start. A few others started to explore the electronic calendaring system, filling in appointments, but kept their paper diaries in parallel. Another group of secretaries virtually ignored the electronic calendar. Secretaries whose professor or manager was a proponent of electronic calendaring picked up the new system better. Learning to work with the electronic calendar was considered easy, and the system was considered to be user friendly. The secretaries who did start to use the electronic calendar felt that they were not really aware of the possibilities of the features. In general the use of the electronic calendaring system was fairly basic.

After implementation, as we noted earlier, the "ECM" project switched somewhat to a softer approach characterized by a more evolutionary project life cycle model. The electronic calendar was in reality still under development as the technical features were further improved. For example; during the first period the implementation users were technically not able to look in each other's 
calendars, this feature was only added later. In addition, after implementation, secretaries expressed the wish to be able to plan room allocation with the electronic calendar. This feature was not available immediately after implementation, but was added a few months later.

\subsubsection{Appropriation of the electronic calendar}

A few months after implementation, the electronic calendar management system was a well-known phenomenon among the secretaries. We label this as the beginning of the ongoing-use stage, although the new system was still being stepwise implemented.

Fourteen secretaries had the electronic calendaring system at their disposal. In general three categories of users could be distinguished:

- a small group of intensive users who replaced their 'traditional' paper diaries with the electronic version;

- a 'middle' group, who regularly used the electronic calendar management system but did not consider the electronic version of the diary as the definitive one. This was still the paper version. This group felt that they understood only the basics of the system at this stage.

- a small group of non-users, who knew little about the basic functions of the system either.

During the ongoing stage, the project leader organized a number of extra information meetings for the secretaries to discuss the electronic calendaring system. The meetings were opportunities to ask questions and give feedback about what the secretaries thought of the system. The project leader summarized the questions and answers in a manual. Secretaries could contact a helpdesk via e-mail and phone if they had problems with, or questions about the system. Secretaries were satisfied with the level of available support.

In addition to the calendar management features, secretaries picked up some of the system's extra features, such as the task-management tool and contacts list, as they were also felt to be useful. Also advantageous were the neat and orderly way of working with the electronic calendar, the possibility to synchronize (provided systems fit), the high level of convenience of the new system and the possibility to manage the e-mail of the manager or professor. The reason that most of the secretaries began to use the electronic calendar was because they expected future improvements, such as a broader implementation within the faculty, and the integration of other facilities (such as planning meeting rooms through the system).

The facility to look into other electronic calendars, to plan appointments with other people outside of the own chair, was less used. This was due to the fact that still only a few people within the faculty, managers and professors, used the electronic calendaring system. Except for the small group that completely 
switched to the electronic calendar, secretaries used the electronic calendar as a copy of the 'traditional' paper version. The reasons for this reserved use was that secretaries experienced a number of disadvantages with electronic calendaring in comparison with the paper version. Firstly, secretaries said that the electronic calendar did not plan "humanely". The new system showed 'free space' in a manager's or a professor's diary, but did not account for the backgrounds to appointments. Secondly, it was less easy with the electronic calendar to see the priority of certain appointments. Thirdly, the fact that there were differences between the systems in use by managers and professors, and the system in use in the secretaries' offices hindered the effective use of the electronic calendar. Fourthly, secretaries in general were experiencing an increase in the level of computer use and 'mouse-clicking'. Finally, a striking observation is that, according to one of the secretaries, the use of an electronic calendaring system results in an increased level of paper use. This secretary had noticed that users printed out calendar overviews on paper.

In the table below, the way users appropriated the electronic calendar is described for each dimension.

\begin{tabular}{|c|c|}
\hline $\begin{array}{l}\text { Aspect of } \\
\text { appropriation }\end{array}$ & Description \\
\hline $\begin{array}{l}\text { Appropriation } \\
\text { moves } \\
=\text { moderate to } \\
\text { high }\end{array}$ & $\begin{array}{l}\text { The level of appropriation moves was moderate to high in the ongoing } \\
\text { use stage. Most secretaries had started to appropriate the system's } \\
\text { features to a certain extent. Only a small group hardly worked with the } \\
\text { electronic calendar at all. }\end{array}$ \\
\hline $\begin{array}{l}\text { Faithfulness of } \\
\text { appropriation = } \\
\text { moderate }\end{array}$ & $\begin{array}{l}\text { The level of faithful appropriation was moderate due to the fact that } \\
\text { certain possibilities (such as planning meetings and appointments in other } \\
\text { chair's calendars) were not available. Therefore, to an extent the system } \\
\text { could not be appropriated in line with the spirit, and some features could } \\
\text { not be appropriated at all. }\end{array}$ \\
\hline $\begin{array}{l}\text { Attitude towards } \\
\text { the electronic } \\
\text { calendar } \\
\text { (perceived } \\
\text { usefulness) = } \\
\text { high }\end{array}$ & $\begin{array}{l}\text { Secretaries experienced the available features as useful. Secretaries } \\
\text { appropriated the system's features more for the individual needs of their } \\
\text { own chair than for getting a 'grip' on the practice of calendar management } \\
\text { in unit } D \text { as a whole. }\end{array}$ \\
\hline
\end{tabular}

Table 7.4 The way users' appropriate the electronic calendar in the ongoing use stage (continued on the next page) 


\begin{tabular}{|c|c|}
\hline & Description \\
\hline appropriation & \\
\hline $\begin{array}{l}\text { Attitude towards } \\
\text { the "ECM" } \\
\text { (perceive ease of } \\
\text { use) = high }\end{array}$ & $\begin{array}{l}\text { To the extent that secretaries were familiar with the available features, } \\
\text { they experienced them as easy to use. During the ongoing use stage } \\
\text { secretaries were invited to information meetings about the available } \\
\text { structures and how to use them. }\end{array}$ \\
\hline $\begin{array}{l}\text { Task-oriented use } \\
=\text { low to } \\
\text { moderate }\end{array}$ & $\begin{array}{l}\text { Task-oriented use was low to moderate. The electronic calendar's } \\
\text { features could not be optimally appropriated in accordance with the spirit } \\
\text { at the beginning of the ongoing use stage due to the fact that some of the } \\
\text { expected features were not available. Besides this, there was still a small } \\
\text { group of secretaries who appropriated the electronic calendar's structures } \\
\text { only to a very low extent. }\end{array}$ \\
\hline $\begin{array}{l}\text { Explorative use = } \\
\text { moderate }\end{array}$ & $\begin{array}{l}\text { Secretaries continued to explore the electronic calendar due to the fact } \\
\text { that the information meetings kept on highlighting new features within the } \\
\text { system. }\end{array}$ \\
\hline $\begin{array}{l}\text { Consensus } \\
\text { among users on } \\
\text { appropriation = } \\
\text { low }\end{array}$ & $\begin{array}{l}\text { The way secretaries appropriated the electronic calendar differed to quite } \\
\text { an extent. Some secretaries appropriated features in accordance with the } \\
\text { spirit where their chair's professor or manager also worked with an } \\
\text { electronic calendar. Others did not, and appropriated features only for } \\
\text { individual needs, and hoped for a 'better future'. }\end{array}$ \\
\hline
\end{tabular}

Table 7.4 The way users' appropriate the electronic calendar in the ongoing use stage

The results in Table 7.4 justify the conclusion that secretaries in unit D appropriated the electronic calendar to a moderate extent. The level of appropriation moves was quite high (but with considerable differences between users), but the level of appropriation in accordance with the system's spirit was only moderate. The system was experienced as highly useful and easy to use, and moderately to highly appropriated in a task-oriented way. In the ongoing use stage, secretaries still felt that they were exploring the system to a moderate extent. The way secretaries appropriated the system's features was also still quite varied.

So far the observations have been on the way secretaries in unit $D$ appropriated the electronic calendar in the ongoing use stage.

\subsubsection{The context of appropriation of the electronic calendar}

The implementation of the "ECM" project was characterized by the following contextual factors (Table 7.5) 


\begin{tabular}{|l|l|}
\hline \multicolumn{1}{|l|}{ Characteristic } \\
\begin{tabular}{|l|l|} 
Level of change in \\
the internal \\
organization
\end{tabular} & $\begin{array}{l}\text { The "ECM" project did not concern a high level of change in the internal } \\
\text { organization according to users. There was no planned aim to change } \\
\text { users' tasks, to change the work place environment, group composition } \\
\text { etc. }\end{array}$ \\
\hline $\begin{array}{l}\text { Level of work } \\
\text { autonomy after } \\
\text { implementation }\end{array}$ & $\begin{array}{l}\text { The office was earlier characterized as a procedural office, which } \\
\text { suggests a relatively low level of work autonomy. In unit D, in general, } \\
\text { the level of work autonomy was experienced as moderate. Users of the } \\
\text { electronic calendar could carry out tasks in the way they prefered, but } \\
\text { users were also dependent on the way staff members asked them to } \\
\text { carry out certain tasks. }\end{array}$ \\
\hline $\begin{array}{l}\text { Satisfaction with } \\
\text { implementation } \\
\text { process }\end{array}$ & $\begin{array}{l}\text { In general secretaries were confident with the "ECM" project leader. } \\
\text { They had confidence in his expertise and skills to manage the } \\
\text { operational part of the project. In general the implementation went } \\
\text { 'smoothly'. It was not experienced as a 'big bang'. }\end{array}$ \\
\hline $\begin{array}{l}\text { Satisfaction with } \\
\text { reason for new } \\
\text { system development }\end{array}$ & $\begin{array}{l}\text { From the project description we learned that, in general, secretaries } \\
\text { had an expectant, passive attitude, in the sense of: 'we'll wait and see'. } \\
\text { However, they supported the project. Only a few of the secretaries } \\
\text { really felt the need for an electronic calendar. }\end{array}$ \\
\hline $\begin{array}{l}\text { Satisfaction with } \\
\text { support when having } \\
\text { problems during the } \\
\text { ongoing use stage }\end{array}$ & $\begin{array}{l}\text { As stated earlier, secretaries had confidence in the "ECM" project } \\
\text { leader/system manager. After implementation, he organized monthly } \\
\text { meetings to inform secretaries about the functionalities of the electronic } \\
\text { calendar. Secretaries could always send an e-mail or phone the } \\
\text { helpdesk for support when having problems. }\end{array}$ \\
\hline
\end{tabular}

\section{Table 7.5 User experience-based project characteristics}

Table 7.5 supports the conclusion that the users of the electronic calendar found that the "ECM" project was not accompanied by a high level of change in the internal organizational environment. The level of work autonomy after the implementation of the electronic calendar was moderate, and users' were moderately to highly satisfied with the way the electronic calendar system was implemented. In general, users were also moderately to highly satisfied with the reasons for implementing the electronic calendar, and were highly satisfied with the support within the organization during appropriating the electronic calendar.

\subsubsection{Project outcomes}

During the ongoing use stage we assessed the "ECM" project outcomes. Table 7.6 below describes the work process effectiveness, anticipated and unanticipated changes, and project costs and duration. 


\begin{tabular}{|c|c|}
\hline Outcome & Description \\
\hline $\begin{array}{l}\text { Work process } \\
\text { effectiveness } \\
=\text { moderate }\end{array}$ & $\begin{array}{l}\text { In the ongoing use stage, secretaries judged the work processes that could } \\
\text { be carried out by the new system as moderately effective. From the project } \\
\text { description we learned that calendar management took around } 30 \% \text { of a } \\
\text { secretary's time. The expectation that the electronic calendar system would } \\
\text { improve the efficiency of calendar management within the organization } \\
\text { (especially between secretaries) did not become a reality during this stage } \\
\text { according to most of secretaries. }\end{array}$ \\
\hline $\begin{array}{l}\text { Unanticipated } \\
\text { changes } \\
=\text { moderate }\end{array}$ & $\begin{array}{l}\text { The "ECM" project led to some noteworthy unanticipated changes. Firstly, } \\
\text { as noted earlier the new system did not result in a clear increase in } \\
\text { efficiency and effectiveness. Secondly, secretaries continued to phone to } \\
\text { each other in order to manage appointments in calendars of different } \\
\text { chairs. Thirdly, the electronic calendar seemed to increase paper use, as } \\
\text { secretaries printed calendar overviews on paper. }\end{array}$ \\
\hline $\begin{array}{l}\text { Anticipated } \\
\text { changes } \\
=\text { moderate }\end{array}$ & $\begin{array}{l}\text { Implementing an electronic calendar in unit D brought about a moderate } \\
\text { level of anticipated changes. In the ongoing use stage, secretaries still did } \\
\text { not appropriate the electronic calendar in the way it was initially meant. The } \\
\text { 'only' anticipated change in the "ECM" project is that the secretaries were } \\
\text { offered a set of technical features with which they could manage the } \\
\text { calendar electronically. A large part of the change that this should bring } \\
\text { about was not achieved. }\end{array}$ \\
\hline $\begin{array}{l}\text { Project costs } \\
=\text { unknown }\end{array}$ & $\begin{array}{l}\text { We do not have clear data on the project budget. What we do know is that } \\
\text { the office automation committee in unit } D \text { had a budget for several projects } \\
\text { and that costs were not really planned formally per project. }\end{array}$ \\
\hline
\end{tabular}

Table 7.6 Project outcomes

Table 7.6 shows that the implementation of the electronic calendar did moderately contribute to the work process effectiveness of unit $\mathrm{D}$. It brought about a moderate level of unanticipated changes, and a moderate level of anticipated changes. We do not have reliable data about whether the project budget was exceeded or not. However, as the "ECM"-project was to an extent managed in an informal way, a clear project budget was not really an issue. The project time schedule was exceeded.

Following this descriptive part of this case study, the next subsection will give attention to the quantitative issues.

\subsection{Testing the hypotheses}

\subsubsection{Hypothesis 1}

In this subsection we will test the first hypothesis regarding the role of user involvement towards the clarity of the spirit. The first hypothesis is: 
The extent to which users have a say in the development and implementation of office technology is positively related to the clarity of the spirit to users.

The analysis of the relevant questionnaire responses results in the following relationships:

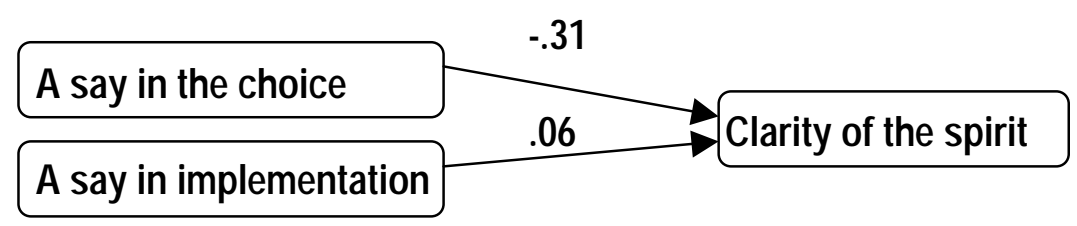

\section{Figure 7.2 The relationship between having a say in the development and implementation, and the clarity of spirit $(\mathrm{N}=14)$}

In the descriptive discussion we noted that, within unit $D$, secretaries in general had hardly any influence in the choice and implementation of the electronic calendar management. The results shown in Figure 7.2 show that the level of involvement did not make a positive contribution towards the clarity of the spirit. In fact, there is a negative relationship (although not statistically significant) between the extent to which secretaries had a say in the choice of system and the clarity of the system's spirit. Our explanation for this is that, after the implementation of the new system, the "ECM" project shifted from a hard approach towards a soft approach. New features were stepwise implemented, accompanied by information meetings organized by the project leader. Because of these information meetings and the good support during appropriation in the institutionalized use stage, lack of user involvement in the earlier stage might not have had any influence on the extent to which the spirit of the new system is clear.

In unit $\mathrm{D}$ we conclude that hypothesis 1 is not confirmed.

\subsubsection{Hypothesis 2}

The clarity of the spirit is expected to be an important determinant of the level of appropriation. This is formulated as follows in the second hypothesis:

The clarity of the spirit to users is positively related to the level of appropriation 
The analysis of the relevant questionnaire responses results in the following relationships:

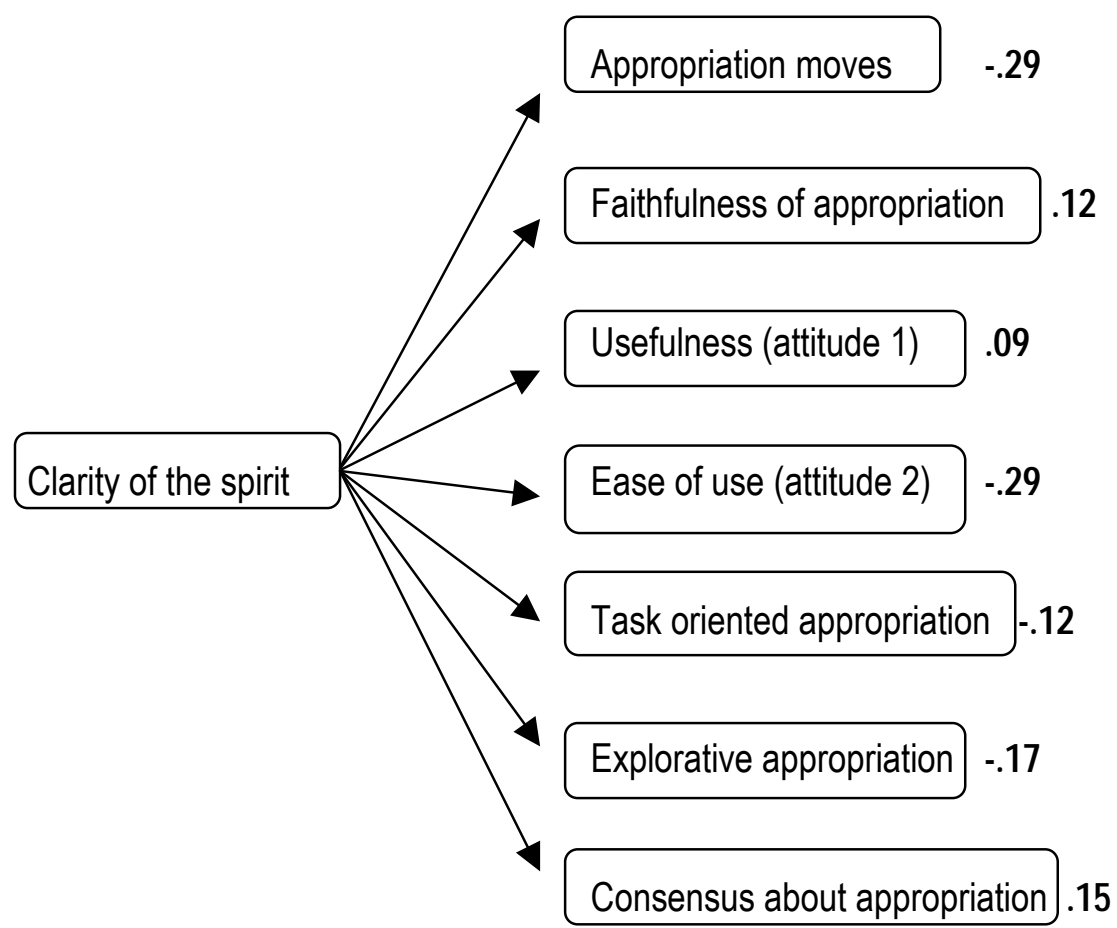

Figure 7.3 The relationships between the clarity of the spirit and the level of appropriation ( $\mathrm{N}=14)$

Regarding the results from unit $\mathrm{D}$, as presented in Figure 7.3 , we observe that none of the correlations are significant (which is to an extent due to the small size of the sample). The clarity of the spirit to users, seems to be unrelated to the level of appropriation of the electronic calendar. This is contrary to our theoretical expectation; our second hypothesis is not confirmed. However, as in the former case studies, the contextual factors included in our research model might provide an explanation. Most notable in the "ECM" project is the low level of internal organizational change accompanying the introduction of the electronic calendar. We think that this is the most reasonable explanation for the observation that a clear spirit does not lead to users appropriating the system to a high degree. In unit $D$, the internal organizational environment was not suitable for letting the intent of the office technology arise during use. The faculty's organizational structure can be described as a matrix, every secretary was committed to a professor or the business manager. Chairs, and their secretaries, could operate as strongly independent entities making efficient electronic collaboration difficult. 


\subsection{Hypothesis 3}

Our third and final hypothesis is:

The level of office technology appropriation is positively related with the level of work process effectiveness

From the questionnaire we obtained the following results:

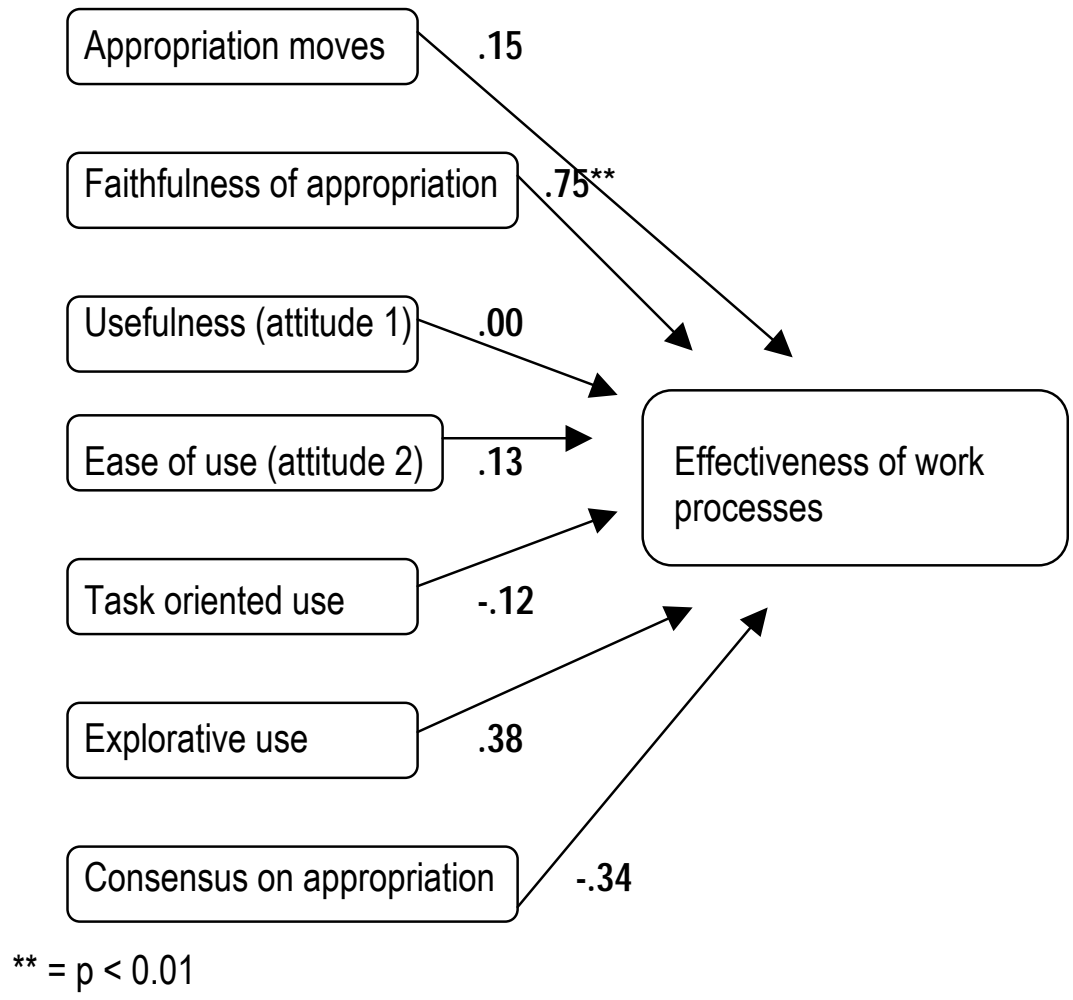

\section{Figure 7.4 The relationship between the level of appropriation and work process effectiveness $(\mathrm{N}=14)$}

We observe that only the faithful appropriation of the electronic calendar is statistically significantly positively related to work process effectiveness. This reflects that, if the system is used in line with the original goals and intention, then the effectiveness of the work processes in the group of users will be improved. That the other correlations are not statistically significant is somewhat disappointing, but can probably be explained by the contextual factors in unit $\mathrm{D}$. As noted earlier, the level of internal organizational change was low in the "ECM" project. The introduction of the electronic calendar might therefore not suit the 
current internal organizational environment. In such a situation, appropriation of the electronic calendar is unlikely to lead to an improvement of work process effectiveness. Though, there is a positive sign in that if the electronic calendar is used as intended, the work process will benefit.

Overall, based upon the low number of significant correlations, hypothesis 3 is not confirmed in unit $D$.

\subsection{Summary of findings}

To summarize, the office technology project in unit $D$ was characterized by a predominantly hard approach until the implementation of the new system. After this we observed that the project shifted towards a softer approach, as system development continued and new features were implemented in a stepwise fashion. The project leader organized regularly meetings with secretaries in order to tell them about new features and to receive feedback. In the "ECM" project performance contribution aspects were the main driving forces for implementing new office technology, and so the human actors involved mainly stressed that the new office technology had to contribute to increasing the performance of the organization.

User involvement in the project was low, although, after the initial implementation of the system, the level of user involvement increased. The spirit of the electronic calendar was characterized as control to increase efficiency and effectiveness of calendar management. Secretaries, in general, expressed the view that they found the system's spirit moderately to quite highly clear. Only a small group started to immediately appropriate the features in line with the spirit. Most secretaries started very cautiously and appropriated only some of the features, and 'rejected' others initially. But, when the project leader organized regular meetings to inform secretaries and to receive feedback, the level of appropriation increased.

In the ongoing use stage, a few months after the implementation of the electronic calendar, secretaries appropriated the new system to a moderate to high extent.

In terms of outcomes, secretaries judged the work process as moderately effective. The new office technology brought about a moderate level of unanticipated change, and a moderate level of anticipated change. Costs were not formally managed in the "ECM" project, and neither was the project time schedule.

When testing our three hypotheses we found that those who were involved during system development and implementation did not find the spirit any clearer than those who were not involved. This can be explained by the fact that, after implementation of the new system, the "ECM" project changed from a hard approach towards a soft approach. Because of adequate information 
exchange during meetings, and good support during appropriation, user involvement might not have had any influence on the extent to which the spirit of the new system is clear.

The clarity of the system's spirit is barely related to the level of appropriation by the secretaries in unit $\mathrm{D}$. Our explanation for this observation is that the internal organizational environment is not suitable for 'realizing' the intents of the new system. Chairs within unit $D$ can operate too independently to allow efficient and effective electronic calendar management between chairs.

Overall, the level of appropriation of the electronic calendar management is not convincingly positively related to the level of work process effectiveness. Our best explanation for the weakness in this relationship lies again in the internal organizational environment. The electronic calendar might just not suit the current situation. 


\section{Eight}

\section{Cross case analysis}

\subsection{Introduction}

In the previous four chapters we reported on the case studies. We described the office projects in terms of the variables of the research model, and tested the three main hypotheses. The goal of testing our hypotheses in the four cases separately was that we hoped to learn from the specific office technology projects. We can learn more from our empirical material if we compare the individual cases. That is this chapter's purpose: placing the cases side-by-side in order to find additional overall insights. The structure of this chapter is as follows: first, we place the project characteristics of each office technology alongside each other and look for notable similarities and differences. Next, we compare the results from the cases of testing the three main hypotheses. After this we test additional hypotheses regarding the influence of context variables as discerned in our research model. In this way we are able to observe to what extent these variables influence the basic relationships between the main variables in our research model. Finally, we reflect on the research model in the light of the overall results.

\subsection{The office technology project characteristics}

For each case, we described the characteristics of the office technology projects in terms of the variables discerned in the research model. We now summarize these characteristics in order to get an overall picture and give attention to the main similarities and differences. The table below summarizes the project characteristics for each case. 


\begin{tabular}{|c|c|c|c|c|}
\hline & Unit A & Unit B & Unit C & Unit D \\
\hline Type of office & $\begin{array}{l}\text { Procedural } \\
\text { office }\end{array}$ & $\begin{array}{l}\text { Procedural } \\
\text { office }\end{array}$ & $\begin{array}{l}\text { Procedural } \\
\text { office }\end{array}$ & $\begin{array}{l}\text { Procedural } \\
\text { office }\end{array}$ \\
\hline $\begin{array}{l}\text { Development } \\
\text { method } \\
\text { approach }\end{array}$ & Hard approach & Hard approach & $\begin{array}{l}\text { At first a hard } \\
\text { approach, after } \\
\text { failure of tests, } \\
\text { a switch was } \\
\text { made towards } \\
\text { a softer } \\
\text { approach }\end{array}$ & $\begin{array}{l}\text { At first a hard } \\
\text { approach, after } \\
\text { implementation } \\
\text { a switch was } \\
\text { made towards } \\
\text { a softer } \\
\text { approach }\end{array}$ \\
\hline $\begin{array}{l}\text { Management } \\
\text { contribution }\end{array}$ & $\begin{array}{l}\text { Performance } \\
\text { contribution } \\
\text { issues }\end{array}$ & $\begin{array}{l}\text { Predominantly } \\
\text { performance } \\
\text { contribution } \\
\text { issues }\end{array}$ & $\begin{array}{l}\text { Predominantly } \\
\text { performance } \\
\text { contribution } \\
\text { issues }\end{array}$ & $\begin{array}{l}\text { At first, } \\
\text { performance } \\
\text { contribution } \\
\text { issues. Later, } \\
\text { also human } \\
\text { issues }\end{array}$ \\
\hline $\begin{array}{l}\text { IT experts' } \\
\text { contribution }\end{array}$ & $\begin{array}{l}\text { Performance } \\
\text { contribution } \\
\text { issues }\end{array}$ & $\begin{array}{l}\text { Predominantly } \\
\text { performance } \\
\text { contribution } \\
\text { issues }\end{array}$ & $\begin{array}{l}\text { At first, } \\
\text { predominantly } \\
\text { performance } \\
\text { contribution } \\
\text { issues. Later, } \\
\text { also human } \\
\text { issues }\end{array}$ & $\begin{array}{l}\text { At first, } \\
\text { predominantly } \\
\text { performance } \\
\text { contribution } \\
\text { issues. Later, } \\
\text { also human } \\
\text { issues }\end{array}$ \\
\hline $\begin{array}{l}\text { User } \\
\text { involvement }\end{array}$ & $\begin{array}{l}\text { Low to } \\
\text { moderate }\end{array}$ & Low & $\begin{array}{l}\text { First low, later } \\
\text { moderate }\end{array}$ & Low \\
\hline $\begin{array}{l}\text { The office } \\
\text { technology's } \\
\text { spirit }\end{array}$ & $\begin{array}{l}\text { Control to } \\
\text { increase } \\
\text { efficiency and } \\
\text { performance, } \\
\text { and reduce } \\
\text { cost and paper } \\
\text { use } \\
\end{array}$ & $\begin{array}{l}\text { Control to } \\
\text { improve } \\
\text { financial risk } \\
\text { management } \\
\text { and efficiency }\end{array}$ & $\begin{array}{l}\text { Better and } \\
\text { more } \\
\text { comfortable } \\
\text { administration }\end{array}$ & $\begin{array}{l}\text { Control to } \\
\text { facilitate } \\
\text { effective and } \\
\text { efficient } \\
\text { calendar } \\
\text { management }\end{array}$ \\
\hline $\begin{array}{l}\text { Technical } \\
\text { features }\end{array}$ & $\begin{array}{l}\text { Highly } \\
\text { restrictive, } \\
\text { moderately } \\
\text { sophisticated } \\
\text { and } \\
\text { comprehensive }\end{array}$ & $\begin{array}{l}\text { Highly } \\
\text { restrictive, } \\
\text { moderately } \\
\text { sophisticated } \\
\text { and } \\
\text { comprehensive }\end{array}$ & $\begin{array}{l}\text { Moderately } \\
\text { restrictive, low } \\
\text { sophistication, } \\
\text { low to } \\
\text { moderately } \\
\text { comprehensive }\end{array}$ & $\begin{array}{l}\text { Lowly } \\
\text { restrictive, } \\
\text { moderately } \\
\text { sophisticated, } \\
\text { highly } \\
\text { comprehensive }\end{array}$ \\
\hline
\end{tabular}

Table 8.1 Summary of office technology project characteristics (continued on next page) 


\begin{tabular}{|c|c|c|c|c|}
\hline & Unit A & Unit B & Unit C & Unit D \\
\hline $\begin{array}{l}\text { Level of } \\
\text { appropriation } \\
\text { of the system }\end{array}$ & Quite high & $\begin{array}{l}\text { Moderate to } \\
\text { high }\end{array}$ & Quite high & $\begin{array}{l}\text { Moderate to } \\
\text { high }\end{array}$ \\
\hline $\begin{array}{l}\text { Context of the } \\
\text { project }\end{array}$ & $\begin{array}{l}\text { Moderate level } \\
\text { of } \\
\text { organizational } \\
\text { change, work } \\
\text { autonomy, } \\
\text { satisfaction } \\
\text { with reasons, } \\
\text { implementation } \\
\text { process and } \\
\text { satisfaction } \\
\text { with support. }\end{array}$ & $\begin{array}{l}\text { Low level of } \\
\text { organizational } \\
\text { change, } \\
\text { moderate level } \\
\text { of work } \\
\text { autonomy, } \\
\text { satisfaction } \\
\text { with reasons } \\
\text { and with } \\
\text { support. Low } \\
\text { level of } \\
\text { satisfaction } \\
\text { with } \\
\text { implementation } \\
\text { process. }\end{array}$ & $\begin{array}{l}\text { Low level of } \\
\text { organizational } \\
\text { change, } \\
\text { moderate to } \\
\text { high level of } \\
\text { work } \\
\text { autonomy, } \\
\text { moderate level } \\
\text { of satisfaction } \\
\text { with reasons } \\
\text { and } \\
\text { implementation } \\
\text { process. } \\
\text { Moderate to } \\
\text { high level of } \\
\text { satisfaction } \\
\text { with support. }\end{array}$ & $\begin{array}{l}\text { Low level of } \\
\text { organizational } \\
\text { change, } \\
\text { moderate level } \\
\text { of work } \\
\text { autonomy, } \\
\text { moderate to } \\
\text { high level of } \\
\text { satisfaction } \\
\text { with reasons } \\
\text { and implemen- } \\
\text { tation, high } \\
\text { level of } \\
\text { satisfaction } \\
\text { with support. }\end{array}$ \\
\hline $\begin{array}{l}\text { Project } \\
\text { outcomes }\end{array}$ & $\begin{array}{l}\text { Moderate level } \\
\text { of work } \\
\text { process } \\
\text { effectiveness, } \\
\text { high level of } \\
\text { unanticipated } \\
\text { and anticipated } \\
\text { change. } \\
\text { Budget and } \\
\text { time schedule } \\
\text { far exceeded. }\end{array}$ & $\begin{array}{l}\text { Low to } \\
\text { moderate level } \\
\text { of work } \\
\text { process } \\
\text { effectiveness, } \\
\text { moderate level } \\
\text { of } \\
\text { unanticipated } \\
\text { and anticipated } \\
\text { change. } \\
\text { Budget and } \\
\text { time schedule } \\
\text { far exceeded. }\end{array}$ & $\begin{array}{l}\text { Moderate level } \\
\text { of work } \\
\text { process } \\
\text { effectiveness, } \\
\text { moderate to } \\
\text { high level of } \\
\text { unanticipated } \\
\text { and low level } \\
\text { of anticipated } \\
\text { changes. } \\
\text { Budget and } \\
\text { time schedule } \\
\text { far exceeded. }\end{array}$ & $\begin{array}{l}\text { Moderate level } \\
\text { of work } \\
\text { process } \\
\text { effectiveness, } \\
\text { moderate level } \\
\text { of } \\
\text { unanticipated } \\
\text { changes, } \\
\text { moderate level } \\
\text { of anticipated } \\
\text { changes. } \\
\text { Budget costs } \\
\text { unknown, time } \\
\text { schedule } \\
\text { considerably } \\
\text { exceeded. }\end{array}$ \\
\hline
\end{tabular}

\section{Continued Table 8.1 Summary of office technology project characteristics}

All the four cases concern office technology projects in procedural offices. In our view the type of environment is therefore very comparable. However, the broader organizational context differs to some extent. Especially, the organizational context of the office technology project in Unit $D$ is somewhat 
unique. This concerned a non-profit organizational context, whereas the other three units involved a profit organizational context. This could make a difference in terms of the organizational culture, which in general in non-profit organizations is considered as "governmental", and less client-driven than in profit organizations.

In reality, differences of this kind did not have a significant impact on other characteristics of the office technology projects. In practice, the four office technology projects have several similarities. We will discuss them briefly here.

First of all, all the office technology projects involved in our study started with a hard approach towards the implicitly or explicitly chosen development method. This might be an indication that in general the dominant development method applied in office technology projects is hard. Notably, in two of them, the project management switched towards a softer approach, after the hard approach had led to problems.

Secondly, in all the office technology projects, the management contributions consisted of emphasizing performance contribution issues, and virtually ignoring organizational environment and human issues. In other words, the management in the projects included in our study reasoned from the point of view that the new office technology had to contribute to the performance of the organization. They lacked any explicit stress that the new office technology should fit the organizational environment in which it was implemented, or should improve the work situation of the users. This observation confirms what we noted in chapter one about the general practice in office technology projects. Lacking attention to organizational and human issues suggests that management believe that making a success out of the implementation of new office technology is to a limited extent a matter of how the technology fits with the organizational environment or with the users' work environment. Management seem to believe that if the technology itself is good, the expected advantages will arise.

IT experts also prefered to look only at the performance contribution side of office technology projects. This, however, is more understandable because in general it can be expected that they are committed to the management's point of view. They "only" are expected to take care of the technical side of the office technology. It is noteworthy that IT experts in at least two of our case studies were the ones who believed that human issues had to be taken into consideration in order to improve the project process. Overall, our study indicates that office technology projects in organizations are mainly IT-driven.

Furthermore, regarding user involvement, the four office technology projects in our study present a disappointing picture; users are poorly involved in the development and implementation of new office technologies. The activities in which they are involved mainly concern the mapping of the system in use, and testing. In these activities users are predominantly information providers, they do not have formal decision-making roles. The observation that users are poorly 
involved fits the picture of the hard approaches towards development methods applied. Especially this aspect of user involvement reflects that, in the four office technology projects, decision-makers had the belief that office technology is something technical, more-or-less static. They did not see it as something that is 'realized' by users during the actual use of the office technology.

The spirits of the office technologies included in this study reflect the consequences of applying a hard approach towards office technology development and implementation. The underlying intents and goals of the technologies implemented, in at least three cases, reflected an attempt to achieve more control of the offices' primary processes in order improve the performance of the organization. In three of the four projects we observed that the technical features of the office technologies are consistent with this spirit. The features were in general highly restrictive, and low to moderate in sophistication and comprehensiveness. It is noteworthy that in the case of unit $D$ the technical features were less restrictive and highly comprehensive, although the office technology's spirit was control-oriented.

Considering this overall characterization of the technical features, we can conclude that the units included in our study required users to realize the spirit with technical features that were restrictive, had a low to moderate sophistication, and low to moderate comprehensiveness. In other words, work processes were to become more efficient by using tools that in general left the user a limited set of actions, supported only basic work procedures, and consisted of a limited or moderate number and variety of features. This is an interesting observation. It indicates that the organizations apparently believed that achieving efficiency, or more generally improving the performance of the organization, is a matter of 'control' rather than a matter of increasing individual or group responsibilities. Technological optimism seemed to prevail in the office technology projects we studied.

Comparing the project characteristics of the four office technology projects indicates that a control-oriented spirit and restrictive technical features do not discourage users from appropriating the new office technology to a moderate to high extent. This is interesting because it would be understandable if users who were not highly involved in a project, and who have to work with an office technology which has little intention of improving the work environment, would not be able or would not be prepared to work with it. However, this observation does support our theoretical starting point that it is especially the clarity of the spirit to users that is crucial in the extent to which users appropriate a new office technology.

As discussed, the level of appropriation of the new system in all the four cases was moderate to high. In none of the cases did users appropriate the new office technology to an extremely low or extremely high extent. This indicates that in none of the cases did users fully reject or adapt to its full extent the new 
office technology. Simply put, it could have been better, but also it could have been worse. That users never completely rejected a newly implemented office technology suggests that users were able to fit the office technology to their work situation. To an extent, they may have been able to change the technology so that it fitted to their needs. Perhaps users changed the spirit of the office technology during the process of appropriation, and consequently did not reject an office technology, but gave it a different meaning to the technical features reflected by the spirit. An office technology's spirit is probably more dynamic than we initially suggested in our theoretical chapter. We will consider this point in the final chapter.

A notable similarity between the four projects concerns the contextual factors. In all the projects the level of organizational change was low. This fits in with our earlier observation that organizational issues were not very explicitly taken into consideration. It suggests that in all projects it is believed that making a success of the implementation of a new office technology is essentially only a matter of the quality of the technology, not of the quality of the organizational environment in which it is introduced. Combining improvements in the office technology with improvements in the organization is not really a factor. Furthermore, in non of the projects, were the levels of work autonomy after the implementation, satisfaction with the implementation process, and the satisfaction with the reasons for implementing a new office technology, high. Only in the unit $D$ case, was the level of satisfaction with the support from the organization during problems with the office technology high. The influence of these contextual factors on the relationship between the clarity of the spirit, and the level of appropriation and the level of appropriation and the level of work process effectiveness, will be discussed in section 8.4.

Finally, when comparing the project outcomes, it is clear that after the implementation of the new office technology the level of work process effectiveness was only moderate in three of the four cases. Users were not really enthusiastic about the way the work processes were going. As we know from the earlier project descriptions, the technologies that were implemented in three of them were very 'present'. In other words, the office technologies were important tools for users in carrying out their tasks. In unit D the office technology implemented (an electronic calendar management system) was only necessary for around $30 \%$ of the users' tasks. It is somewhat surprising to observe that, in this case, users perceived the new work processes as most effective in comparison to the other three studies. It would seem that office technologies that were necessary tools for carrying out tasks did not really contribute to the effectiveness of the work processes in the other three cases. Later on, when we inventorize the results regarding our hypotheses, we will elaborate on this point.

Even more surprising is that the level of unanticipated changes in two of the projects was moderate, in one project moderate to high, and in the other 
project high. Office projects resulted in a considerable number of changes that were neither expected nor planned. This despite the hard approaches applied in these projects, which imply fairly structured and planned development and implementation. It is also clear that planning and structuring effect project costs and scheduling; from three of the four projects we know that the budgets were far exceeded and in all four projects we observed that they required significantly more time.

So far we have compared the characteristics of the four office technology projects in this study. In the next section we will compare the outcomes of each project in testing our three main hypotheses.

\subsection{Comparing the outcomes of the hypotheses}

A major part of the study concerns the testing of the relationships between the variables in the research model. We formulated three main hypotheses and seven additional hypotheses and tested them in the office technology projects included in this study. In this section we compare the results of testing the three main hypotheses, in order to be able to obtain an overall view. In addition, our approach to obtaining an overall view can be facilitated by creating one overall dataset, comprising the four separate datasets. The hypotheses can then also be tested on this overall dataset. The results will provide us with a further indication of whether a hypothesis is correct or not. Nevertheless, in discussing the results, our main interest lies with the differences and similarities between the four separate cases.

Comparing the results of testing hypothesis 1

First, we start with hypothesis 1 that concerns the relationship between the level of user involvement and the clarity of the spirit.

The extent to which users have a say in the development and implementation of office technology is positively related to the clarity of the spirit to users.

Table 8.2 summarizes the correlations between these two variables for each office technology project and presents the correlations resulting from the combined dataset. 


\begin{tabular}{|c|c|c|c|c|c|}
\hline & Unit A & Unit B & Unit C & Unit D & Overall \\
\hline $\begin{array}{l}\text { Involvement in } \\
\text { development }\end{array}$ & .33 & .16 & $.48^{*}$ & -.31 & $.27^{\star}$ \\
\hline $\begin{array}{l}\text { Involvement in } \\
\text { implementation }\end{array}$ & .25 & .15 & $.46^{*}$ & .06 & $.29 * *$ \\
\hline
\end{tabular}

${ }^{*}=p<0.05 ;{ }^{*}=p<0.01$

\section{Table 8.2 Summary of results for hypothesis 1}

Overall, Table 8.2 shows that there is a significant positive relationship between user involvement and the clarity of spirit. This means that users who had a say in the development or the implementation of a new office technology, have a clearer picture of the system's spirit than users who did not have a say. Based upon our four case studies it can be said that involving users in office technology development does contribute to making the intention of office technologies clear to users.

If we look at the results of the individual cases, a noteworthy aspect is that in only one case (unit $\mathrm{C}$ ) is the relationship quite strong and significant. We know from the case description that the initial approach to office technology development and implementation in unit $\mathrm{C}$ was hard, but later this switched to a softer approach. User involvement from that moment on was a closer collaboration between IT experts and users in order to design the user applications. This might explain why in this case the correlation between user involvement and the clarity of the spirit is the strongest.

Another interesting aspect is the quite negative correlation in unit $D$ between having a say in the development and the clarity of the spirit. We did not find a satisfactory explanation for this in the case description. We know from the case description that this case concerned an electronic calendar management system, that was customized by an internal IT expert but purchased as a standard package. One plausible explanation in our view is that the spirit of the system may have altered between the moment when it was decided what system to buy and the ongoing use stage. In the in between period the goals and intention could have been discussed in the project team and as a result changed somewhat. It could also be the case that users who were involved in deciding which system to buy found that when really working with the system, they no longer felt that the initial goals and intention were clear. The possibility of 
changes in a system's spirit during use is an interesting point to keep in mind for the following, concluding chapter.

From the individual cases we learned that the fact that the correlations in some cases are somewhat weak is due to the other ways through which users (who are not involved in development and/or implementation) can get acquainted with a new system's spirit. These include: by simply using the system, through user training sessions, and also through delays in office technology projects that give future users time and opportunity to become informed about the new system (for example: from users that are involved during tests).

In conclusion, as shown in upon Table 8.2, the overall results show that the relationship between user involvement and the clarity of spirit is significantly positive.

Comparing the results of testing hypothesis 2

Our second hypothesis was:

The clarity of the spirit of office technology is positively related with the level of office technology appropriation.

Table 8.3 summarizes the results for each case and the correlations from the overall dataset.

\begin{tabular}{|l|c|c|c|c|c|}
\multicolumn{6}{|c|}{ Correlations between the clarity of the spirit and the level of appropriation } \\
\begin{tabular}{|l|c|c|c|c|} 
unit A \\
unit B
\end{tabular} & -.02 & -.21 & -.29 & -.11 \\
\hline $\begin{array}{l}\text { Appropriation } \\
\text { moves }\end{array}$ & -.09 & -.02 & .27 & .12 & $.26^{* *}$ \\
\hline $\begin{array}{l}\text { Faithfulness of } \\
\text { appropriation }\end{array}$ & .25 & .34 & $.48^{*}$ & .09 & $.39^{* *}$ \\
\hline $\begin{array}{l}\text { Perceived } \\
\text { usefulness }\end{array}$ & $.66^{* *}$ & .23 & .41 & -.29 & $.42^{* *}$ \\
\hline $\begin{array}{l}\text { Perceived ease } \\
\text { of use }\end{array}$ & $.52^{* *}$ & $.49^{*}$ & .31 & & \\
\hline $\begin{array}{l}\text { Task oriented } \\
\text { use }\end{array}$ & $.38^{*}$ & $.57^{* *}$ & -.12 & -.12 & $.26^{* *}$ \\
\hline Explorative use & -.13 & .16 & -.10 & -.17 & -.04 \\
\hline $\begin{array}{l}\text { Consensus on } \\
\text { appropriation }\end{array}$ & .10 & $.39^{*}$ & -.16 & .15 & .04 \\
\hline
\end{tabular}

${ }^{*}=p<0.05 ;{ }^{*}=p<0.01$

Table 8.3 Summary of correlations between the clarity of the spirit and the level of appropriation 
From the results as presented in Table 8.3 we can observe that overall there is a weak negative relationship between the clarity of the spirit and the level of appropriation moves. In other words, the clarity of the spirit is not decisive in the extent to which users really work with the office technology. This topic has already been discussed for the separate cases. The main explanation is that other organizational factors, such as the nature of work, are more decisive. All our four cases concerned office technology projects in procedural offices. The technology in general was an important tool for users in carrying out their tasks, and therefore in many cases there were no alternatives.

Overall there is a weak to moderate significant positive relationship between the clarity of the spirit and the level of faithful appropriation. More explicitly: if users experience the technology's spirit as clear, this contributes to the extent to which they work with the technology in line with its spirit. The fact that this relationship is only weak to moderate can be explained by the role played by organizational contextual factors. Especially the extent to which users agree upon the reasons for the new office technology implementation might be an important explainatory factor. Is it very likely that users can find the spirit clear but still not fully agree upon the reason for new office technology implementation. Therefore, if we control for this factor, the relationship is likely to become stronger. The role of this factor is the subject of one of the additional hypotheses tested in the next section.

The clarity of the spirit is in two cases strongly positively related to the perceived usefulness of the office technology. The overall results indicate that the relationship is positive and significant. In other words, the extent to which the spirit of an office technology is clear to users influences their perception of a technology's usefulness in a positive way. This also applies to the perception of a technology's ease of use and to the level of task-oriented use. However, if we look at the individual case results, we can see that in two cases there were weak negative relationships between the clarity of the spirit and the level of task oriented use. In the earlier case chapters this has already been discussed. In our research model we included a number of intervening contextual factors that might provide explanations (these are tested in the next section). In our view the level of work autonomy can best explain the weakly negative relationship. The more autonomy users experience in their work, the more alternatives they have to working in a task-oriented way with the technology (as in unit D where calendar management took only around $30 \%$ of secretaries' time).

Regarding the level of explorative use we found a weak negative correlation. This is in line with our theoretical expectations. The clearer the spirit to users, the less users need to explore the system. However, we expected a somewhat stronger negative correlation. In the following section we will determine which of the contextual factors can provide the strongest explanation, 
but it seems likely that the level of support with problems during appropriation plays an important role.

Finally, in three of the four cases, there is a positive relationship between the clarity of the spirit and the level of consensus on appropriation. However, in only one of these three cases the correlation is statistically significant. The results suggest that the clearer that users find the spirit of an office technology, the more there is unanimity among users on how to work with the technology.

In conclusion, unit $\mathrm{D}$ draws attention because the relationship between the clarity of the spirit and the level of appropriation is the weakest of the four cases. Overall, however, we can onclude that our second hypothesis is confirmed for the majority of the dimensions of the concept of appropriation, namely for faithful appropriation, perceived usefulness, perceived ease of use and task-oriented use.

Comparing the results of testing hypothesis 3

The final hypothesis that was tested for each case is as follows:

The level of office technology appropriation is positively related to the level of work process effectiveness

As with the previous hypotheses, the results for each case, and the results of the combined dataset, are summarized (Table 8.4).

\begin{tabular}{|c|c|c|c|c|c|}
\hline \multicolumn{6}{|c|}{$\begin{array}{c}\text { Correlations between the level of appropriation and work process } \\
\text { effectiveness }\end{array}$} \\
\hline & Unit A & Unit B & Unit C & Unit D & Overall \\
\hline $\begin{array}{l}\text { Appropriation } \\
\text { moves }\end{array}$ & -.28 & -.10 & -.14 & .15 & -.18 \\
\hline $\begin{array}{l}\text { Faithfulness of } \\
\text { appropriation }\end{array}$ & .24 & -.01 & -.05 & $.75^{* *}$ & 13 \\
\hline $\begin{array}{l}\text { Perceived } \\
\text { usefulness }\end{array}$ & $.37^{*}$ & .17 & .25 & .00 & $.36^{* *}$ \\
\hline $\begin{array}{l}\text { Perceived ease of } \\
\text { use }\end{array}$ & .16 & $.55^{\star \star}$ & .31 & .13 & $.40^{* *}$ \\
\hline Task-oriented use & .16 & -.04 & -.13 & -.12 & -.01 \\
\hline Explorative use & -.14 & -.10 & .02 & .38 & -.04 \\
\hline $\begin{array}{l}\text { Consensus on } \\
\text { appropriation }\end{array}$ & $39^{* *}$ & $.42^{*}$ & .31 & -.34 & $.32^{* *}$ \\
\hline
\end{tabular}

${ }^{*}=p<0.05 ;{ }^{* *}=p<0.01$

Table 8.4 Summary of correlations between the level of appropriation and work process effectiveness 
Table 8.4 shows the following:

Across the cases we can observe that the level of appropriation moves ('just pushing buttons') does not make a significant difference in work process effectiveness.

In two of the four cases, faithful appropriation of the technology is hardly related at all with work process effectiveness, in one other case it is weakly positively related, and in the fourth case it is significantly strongly, positively related. Overall, the results suggest that using the technology in line with its goals and intention is poorly related to a higher level of work process effectiveness. Although theoretically unexpected, plausible explanations are expected to come from the contextual factors included in the research model, namely the level of internal organizational change as part of the project, and the level of users' work autonomy. However, what can be learned from the overall result is that the spirits, as described in the four separate projects, do not represent what is considered as necessary by users in order to improve the work process effectiveness. Furthermore, the result suggests that in three of our four cases the technology is only one factor that plays a role in determining work process effectiveness. Other factors, summarized as the organizational context (organizational structure (division of tasks, responsibilities etc.) and organizational culture (e.g. the type of leadership, communication style)) also play a role. An interesting question is, why is faithful appropriation of the office technology so strongly positively related to work process effectiveness in unit D? The research model uses two contextual factors to explain why this result deviates from the other three cases. These are the level of organizational change that accompanied the project and the level of users' work autonomy. In the case of unit $D$ these two factors are not really that different than in the other three cases. It is especially other contextual factors, such as the level of satisfaction with the reasons for implementation, the level of satisfaction with the implementation process, and the level of support with problems during office technology use that differin unit $D$ in comparison with the other three cases. In unit $D$ users are more positive about these aspects than in the other situations. This could explain the strong relationship in unit $D$. Therefore, although not discussed in chapter two, this observation should be kept in mind for the final chapter.

In unit $A$ (the workflow management case) the level of perceived usefulness is significantly positively related to the level of work process effectiveness. In two of the other cases the relationship is weakly positive (but not statistically significant). Overall, in our view, there are convincing indications that when users perceive an office technology to be useful, this contributes to the work process effectiveness. 
Across all our four cases, the extent to which users perceive the new system as easy to use is positively related to the level of work process effectiveness. That the relationship is in general somewhat weak indicates in our view that contextual factors (such as aspects of the organizational structure, and culture, or employee characteristics) are at least of equal importance in contributing to work process effectiveness.

Task-oriented use of the new system is in most of our cases only weakly negatively related to work process effectiveness. Theoretically this is very surprising. In our view, this result again emphasizes that contextual factors are very important regarding any improvement of work process effectiveness. It is clearly not only the new system that makes a difference in improving work process effectiveness.

Explorative use of a new system is in two cases positively related with work process effectiveness, in the other two cases they are weakly negatively related. Theoretically, we expected that explorative use of an office technology would be negatively related with the effectiveness of the work processes. The positive relationship in some cases can be explained by the fact that it is surely not only the new system that has a role in terms of the level of work process effectiveness. Other, contextual factors 'intervene' in the relationship between explorative use and work process effectiveness. Especially the result in unit D warrants attention. In this case the spirit and the technical features of the electronic calendar did not really fit. The technical features were only slightly restrictive and also highly sophisticated, although the intention underlying these features was to get more 'grip' on calendar management. From the case description we could see however that users found new more attractive goals when using the electronic calendar. In other words, by exploring the features, users found ways to use the system in a more meaningful way in their work. The question that this raises is whether it is possible to say that the spirit of the electronic calendar changed during its actual use by users? As we suggested something similar earlier in this chapter, we will carry this forward to the final chapter.

Consensus on appropriation in three of our four cases is positively related to work process effectiveness (in two cases the correlation is significant). In other words, the more users work in a similar way with a new system, the higher the effectiveness of the work processes. The observation that, in unit D, consensus on appropriation is negatively related to work process effectiveness is, in our view, explained by the fact that users here had quite distinct jobs. Therefore, whether or not users worked with the system in similar ways did not really affect work process effectiveness. This is also included in the contextual factors proposed in the research model.

Considering the overall results with regard to the third hypothesis we conclude that it is confirmed for three of the seven dimensions of appropriation, 
namely perceived usefulness, perceived ease of use and consensus on appropriation. The fact that in some cases the relationship is somewhat weak, or even not positive, must in our view, be explained by the context in which the office technology is used (e.g. aspects of the organizational structure, culture, and employee characteristics). These factors are expected to play an intervening role. It is clearly not only appropriating an office technology that improves work process effectiveness.

\subsection{The role of contextual factors}

In chapter two we theorized about the role of the context in which office technology use takes place, and its effects on work process effectiveness. We introduced five factors: the level of satisfaction with the implementation process, the level of satisfaction with the reasons for office technology implementation, the level of satisfaction with the organizational support during new office technology appropriation, the level of change in the internal organizational environment, and the level of work autonomy of users.

We hypothesized about the effect of these five factors on the relationship between the clarity of the spirit and the level of appropriation. These hypotheses are presented below:

The relationship between the clarity of spirit and office technology appropriation is more positive among:

2a. users who are highly satisfied with the way new office technology is implemented;

$2 b$. users who highly agree with the reasons for new office technology implementation;

2c. users who are highly satisfied about the organizational support during new office technology appropriation;

$2 d$. users who experienced a high level of change in the internal organizational environment that accompanied a new office technology project;

2e. users who experience a high level of work autonomy after new office technology implementation.

The way the contextual factors influence the relationship between the clarity of the spirit and the level of appropriation is illustrated in the following figure, which forms part of our research model. 


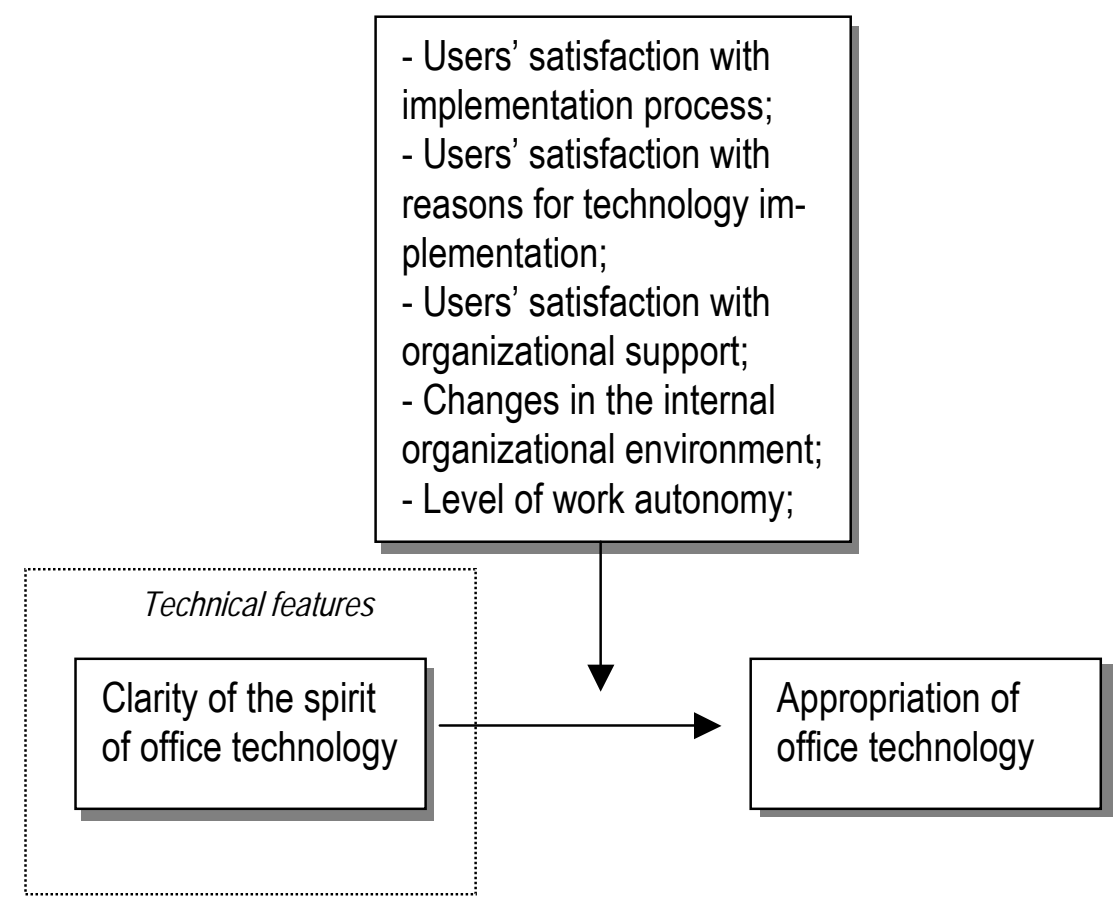

Figure 8.1 Part of the research model

Furthermore, we hypothesized on the role of two of these contextual factors on the relationship between the level of appropriation and work process effectiveness. These factors are the level of change in the internal organizational environment, and the level of work autonomy. The hypotheses are presented below:

The relationship between the level of appropriation and work process effectiveness is more positive among:

3a. users who experience a high level of change in the internal organizational environment that accompanied new office technology implementation; $3 b$. users who experience a high level of work autonomy after new office technology implementation.

These hypotheses are presented in Figure 8.2 and form another part of the research model. 


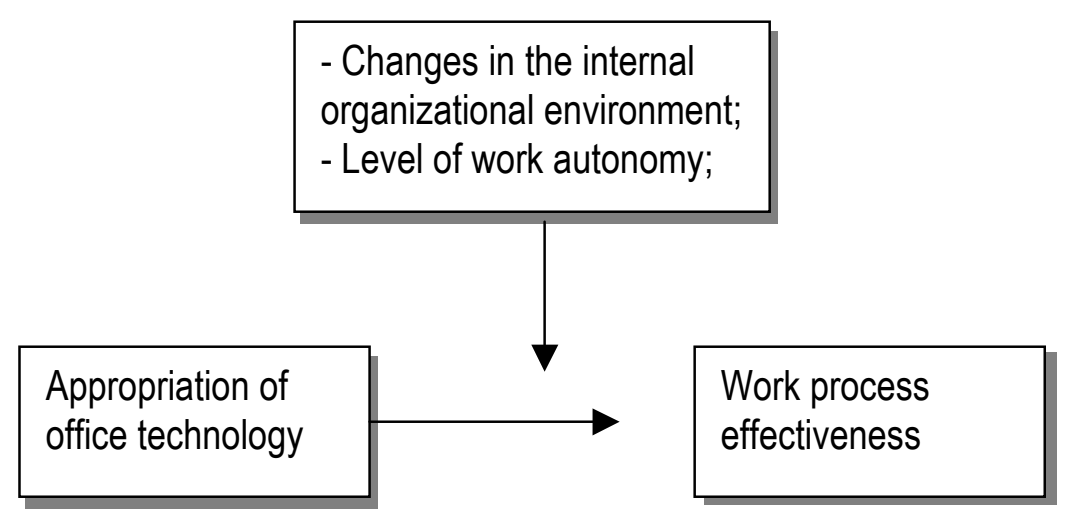

\section{Figure 8.2 Another part of the research model}

To test hypotheses $2 \mathrm{a}$ to $2 \mathrm{e}$ and $3 \mathrm{a}$ and $3 \mathrm{~b}$, we again combined the quantitative datasets from the separate cases into one dataset. We consider that hypotheses $2 \mathrm{a}$ to $2 \mathrm{e}$ and $3 \mathrm{a}$ and $3 \mathrm{~b}$ can only be usefully tested by using a combined dataset. As we explained in chapter three, the individual datasets are rather small and we wish to further divide our dataset into two at this stage. To test hypotheses $2 \mathrm{a}$ to $2 \mathrm{e}$ and $3 \mathrm{a}$ and $3 \mathrm{~b}$ we split the combined quantitative dataset into two groups: one group with users who rated low on a particular variable, another group with users who rated high on the same variable. Respondents that scored 3.0 or lower were placed in the 'low' group and the remainder in the 'high' group. In comparing the two groups we pay particularly attention to the differences in the number of significant correlations and the differences in the strength of the significant correlations.

First of all, we start with hypotheses 2a to $2 \mathrm{e}$.

2a. The relationship between the clarity of the spirit and office technology appropriation is more positive among users who are highly satisfied with the way new office technology is implemented;

To test hypothesis 2a we followed the procedure as explained above. The results are presented in Table 8.5. 


Correlation between the clarity of the spirit and the level of appropriation in
a group of users that is highly satisfied and a group that is lowly satisfied
with the implementation process
\begin{tabular}{|l|c|c|c|c|c|c|c|}
\hline $\begin{array}{l}\text { Lowly satisfied } \\
\text { group of users } \\
(\mathrm{N}=55)\end{array}$ & .06 & .11 & $.33^{*}$ & $.44^{* *}$ & $.40^{* *}$ & .14 & .16 \\
\hline $\begin{array}{l}\text { Highly satisfied } \\
\text { group of users } \\
(\mathrm{N}=44)\end{array}$ & -.16 & $.50^{* *}$ & .29 & .13 & .18 & -.29 & .11 \\
${ }^{*}=p<0.05{ }^{* *}=p>0.01$ & & & & & & \\
\hline
\end{tabular}
mov = appropriation moves; faith = faithful appropriation; usef = perceived usefulness;
ease = perceived ease of use; task = task-oriented use; expl = explorative use; cons =
consensus on appropriation

Table 8.5 Correlation between the clarity of the spirit and the level of appropriation in a users group that is highly satisfied and a users group that is lowly satisfied with the implementation process

The results show that, in general, in the group of users that is lowly satisfied with the implementation process, the relationship between the clarity of the spirit and the level of appropriation is more positive than in the group of users that is highly satisfied. This is surprising, and not in line with our hypotheses. In other words, the quality of the way in which a new office technology is implemented does not positively influence the relationship between the clarity of the spirit and the level of appropriation. However, in one key element the results are in line with our expectation: among users who are highly satisfied with the implementation process the clarity of the spirit is much more positively related to the level of appropriation in accordance with the spirit, than among users who are lowly satisfied. This is an important element because it indicates that an adequate implementation process contributes to a higher level of working with the office technology in accordance with its spirit.

In conclusion, overall, hypothesis $2 a$ is rejected. Interestingly, it is only confirmed in terms of the relationship between the clarity of the spirit and the level of faithful appropriation. 
$2 b$. The relationship between the clarity of the spirit and office technology appropriation is more positive among users who highly agree with the reasons for new office technology implementation.

In testing this hypothesis we followed the same procedure as with hypothesis $2 \mathrm{a}$.

Correlation between the clarity of the spirit and the level of appropriation in
a group of users that highly agrees and a group of users that poorly agrees
with the reasons for new office technology implementation
mov
faith

${ }^{*}=p<0.05 ;{ }^{* *}=p>0.01$

mov = appropriation moves; faith = faithful appropriation; usef = perceived usefulness; ease $=$ perceived ease of use; task = task-oriented use; $\operatorname{expl}=$ explorative use; cons = consensus on appropriation

Table 8.6 Correlation between the clarity of the spirit and the level of appropriation in a group of users that highly agrees and a group of users that poorly agrees with the reasons for new office technology implementation

The results in Table 8.6 show very convincingly that the relationship between the clarity of the spirit and the level of appropriation is more positive with the group of users that highly agree with the reasons for new office technology implementation. In other words, if users agree with the reasons for new office technology implementation, the clearer is the spirit to them and the better they appropriate the office technology. In conclusion, the extent to which users agree with the reasons for new office technology implementation is an important contextual factor. Our second additional hypothesis is confirmed.

2c. The relationship between the clarity of the spirit and office technology appropriation is more positive among users who are highly satisfied about the organizational support during new office technology appropriation.

The results of testing this hypothesis are shown in Table 8.7. 


\begin{tabular}{l} 
Correlation between the clarity of the spirit and the level of appropriation in \\
a group of users that is highly satisfied and a group of users that is poorly \\
satisfied with the organizational support during new office technology \\
appropriation \\
$\qquad$\begin{tabular}{l|c|c|c|c|c|c|c|} 
mov & faith \\
usef & ease & task & expl & cons \\
\hline $\begin{array}{l}\text { Group of users which } \\
\text { is poorly satisfied } \\
\text { (N=50) }\end{array}$ & -.19 & .22 & $.28^{*}$ & $.37^{* *}$ & .24 & .02 & .22 \\
\hline $\begin{array}{l}\text { Group of users which } \\
\text { is highly satisfied } \\
(\mathrm{N}=54)\end{array}$ & .05 & $.40^{* *}$ & $.51^{* *}$ & $.49^{* *}$ & $.32^{*}$ & -.19 & .22 \\
\hline
\end{tabular} \\
\hline
\end{tabular}

${ }^{*}=p<0.05 ;{ }^{* *}=p>0.01$

mov = appropriation moves; faith $=$ faithful appropriation; usef = perceived usefulness; ease $=$ perceived ease of use; task = task-oriented use; expl = explorative use; cons = consensus on appropriation

Table 8.7 Correlation between the clarity of the spirit and the level of appropriation in a group that is highly satisfied and a group that is lowly satisfied with organizational support during office technology appropriation

If we consider the number of significant correlations and their strengths, then Table 8.7 clearly shows that the relationship between the clarity of the spirit and the level of appropriation is most positive in the group of users that is highly satisfied with the organizational support during office technology appropriation. This indicates that adequate organizational support is a contributing contextual factor with regard to the use of office technology in line with its intention. We conclude that hypothesis $2 \mathrm{c}$ is confirmed.

$2 d$. The relationship between the clarity of the spirit and office technology appropriation is more positive among users who experienced a high level of change in the internal organizational environment that accompanied a new office technology project.

For testing this hypothesis we followed the same procedure as before; the respondents were divided into two groups: one group that experienced a low level of change, another one that experienced a high level of change. The results are shown in Table 8.8. 


\begin{tabular}{l} 
Correlation between the clarity of the spirit and the level of appropriation in \\
a group of users that experienced a high level and a group that \\
experienced a low level of organizational change during the office \\
technology project \\
$\qquad$\begin{tabular}{l|c|c|c|c|c|c|c|} 
mov & faith & usef & ease & task & expl & cons \\
\hline $\begin{array}{l}\text { "Low change level" } \\
\text { group of users } \\
\text { (N=62) }\end{array}$ & -.16 & $.45^{* *}$ & $.37^{* *}$ & $.56^{* *}$ & .19 & .00 & .01 \\
\hline $\begin{array}{l}\text { "High change level" } \\
\text { group of users } \\
\text { (N=31) }\end{array}$ & -.25 & .06 & .30 & .15 & .32 & -.21 & .18 \\
\hline
\end{tabular} \\
\hline
\end{tabular}

${ }^{*}=p<0.05 ;{ }^{* *}=p>0.01$

mov = appropriation moves; faith = faithful appropriation; usef = perceived usefulness; ease $=$ perceived ease of use; task = task-oriented use; expl = explorative use; cons = consensus on appropriation

Table 8.8 Correlation between the clarity of the spirit and the level of appropriation in a group that experienced a high level and a group that experienced a low level of organizational change during the office technology project.

Overall, Table 8.8 indicates that the relationship between the clarity of the spirit and the level of appropriation is most positive among users who experienced a low level of change in the internal organizational environment during the office technology project. Our expectation had been that new office technology implementation would be better accepted by users if this was combined with changes in the internal organizational environment. Hypothesis $2 \mathrm{~d}$, therefore, is not confirmed. What should we learn from this result and how can this result be explained?

First of all, we can conclude that organizational changes, as part of office technology projects, influence the relationship between the clarity of the spirit and the level of appropriation. The results suggest that users who experience the spirit of the office technology as clear, do not appropriate the office technology to a higher extent than those who do not, if they experience a high level of organizational change during the project. An explanation for this observation might be that apparent organizational change causes extra confusion, which makes it more difficult for users to appropriate the technology, although they do find its spirit clear. However, we favour another explanation for this unexpected result. The projects included in our study all rated low to moderate on the level of anticipated organizational change, but rated moderate to high on the level of unanticipated change. It is especially this unexpected, and unplanned, element of the organizational change that can explain why users who experienced a high level of change did not appropriate the office technology 
to a higher extent, although they did experience its spirit as clear. In other words, unexpected changes mean extra uncertainty and extra stress for users, and this makes it harder for them to appropriate a new office technology, even when its spirit is clear.

2e. The relationship between the clarity of the spirit and office technology appropriation is more positive among users who experience a high level of work autonomy after new office technology implementation.

The results are shown in Table 8.9.

\begin{tabular}{|c|c|c|c|c|c|c|c|}
\hline \multicolumn{8}{|c|}{$\begin{array}{c}\text { Correlation between the clarity of the spirit and the level of appropriation in } \\
\text { a group of users that experienced a high level and a group that } \\
\text { experienced a low level of work autonomy }\end{array}$} \\
\hline & mov & faith & usef & ease & task & expl & cons \\
\hline $\begin{array}{l}\text { "Low work } \\
\text { autonomy" group } \\
\text { of users ( } N=47)\end{array}$ & .14 & .27 & $.33^{*}$ & $60^{* *}$ & $.58^{\star \star}$ & .06 & .25 \\
\hline $\begin{array}{l}\text { "High work } \\
\text { autonomy" group } \\
\text { of users } \\
(\mathrm{N}=61)\end{array}$ & -.20 & $28^{*}$ & $.46^{* \star}$ & $.29^{*}$ & .14 & -.19 & -.04 \\
\hline \multicolumn{8}{|c|}{${ }^{*}=p<0.05 ;{ }^{* *}=p>0.01$} \\
\hline
\end{tabular}

Table 8.9 Correlation between the clarity of the spirit and the level of appropriation in a group that experienced a high level and a group that experienced a low level of work autonomy

The results in Table 8.9 show a quite complicated picture. The relationship between the clarity of the spirit and the level of appropriation is only more positive in the 'high work autonomy' group in terms of faithful appropriation and useful appropriation. However, overall the differences are not pronounced. It is more reasonable to conclude that the relationship between the clarity of the spirit and the level of appropriation is more positive in the 'low work autonomy' group in terms of the perceived ease of use and task-oriented use. This is not in accordance with our hypothesis, and requires an explanation.

Users with a low level of work autonomy do not have many alternatives other than to carry out their day-to-day tasks with the newly implemented office technology. Users with a high level of work autonomy might have the choice to 
carry out the tasks with or without the office technology, or to carry out other tasks. Therefore, users with limited autonomy use the technology in a more taskoriented way and perceive it as easier to use, if they experience its spirit as clear.

In conclusion, overall hypothesis $2 \mathrm{e}$ is not confirmed. The results show that the level of work autonomy does influence the relationship between the clarity of the spirit and the level of appropriation. However, only among users with a low level of work autonomy is the relationship more positive regarding task-oriented use and perceived ease of use.

After testing the influence of the contextual factors on the relationship between the clarity of the spirit and the level of appropriation (hypotheses 2a to $2 e$ ), we continue with testing the role of two of the contextual factors on the relationship between the level of appropriation and work process effectiveness. For testing these hypotheses we again split the respondents into two groups: one group containing those with a high score on a contextual factor, and the other group those with a low score. As before, respondents who rated higher than 3.0 on the five point scale with which we measured the factor were placed in the "high" group, respondents who rated 3.0 or lower were placed in the "low" group.

First, hypothesis 3a:

3a. The relationship between the level of appropriation of new office technology and the level of work process effectiveness is more positive among users who experience a high level of change in the internal organizational environment that accompanied new office technology.

The results are shown in Table 8.10. 


Correlation between the level of appropriation and work process
effectiveness in groups of users which experienced high and a low levels
of internal organizational change
\begin{tabular}{|l|c|c|c|c|c|c|c|} 
mov faith & usef & ease & task & expl & cons \\
\hline $\begin{array}{l}\text { "Low change" group of } \\
\text { users (N=62) }\end{array}$ & -.22 & .02 & $.39^{* *}$ & $.53^{* *}$ & .05 & -.04 & $.29^{*}$ \\
\hline $\begin{array}{l}\text { "High change" group of } \\
\text { users } \\
(\mathrm{N}=30)\end{array}$ & -.16 & .21 & $.37^{*}$ & .35 & -.17 & -.20 & $.41^{*}$ \\
\hline
\end{tabular}

${ }^{*}=p<0.05 ;{ }^{* *}=p>0.01$

mov = appropriation moves; faith = faithful appropriation; usef = perceived usefulness; ease = perceived ease of use $;$ task = task-oriented use; expl = explorative use; cons = consensus on appropriation

Table 8.10 Correlation between the level of appropriation and work process effectiveness in groups which experienced high and low levels of internal organizational change

The results in Table 8.10 make clear that our hypothesis is only confirmed in terms of the level of consensus on appropriation. In other words, in the group of users who experienced a high level of change in the internal organization, the higher the consensus on appropriation, the higher the level of work process effectiveness. Otherwise, the level of organizational change only makes a real difference in the relationship between the perceived ease of use and work process effectiveness. Among users who experienced a low level of organizational change, the more the office technology is perceived as easy to use, and the higher the level of work process effectiveness. This is not in line with our expectations. Therefore, how can this be explained? In our view, an almost similar justification can be given as with hypothesis $2 \mathrm{~d}$. The organizational changes in the projects we covered were in general quite unanticipated. The appropriation of the new office technology might not contribute to work process effectiveness because of this high level of unanticipated organizational change.

The overall conclusion is that the level of internal organizational change does not make a real difference in the relationship between the level of appropriation and work process effectiveness.

$3 b$. The relationship between the level of appropriation and work process effectiveness is more positive among users who experience a high level of work autonomy. 


\begin{tabular}{l} 
Correlation between the level of appropriation and work process \\
effectiveness in groups of users which experienced high and low levels of \\
work autonomy \\
\begin{tabular}{|l|c|c|c|c|c|c|c|} 
mov & faith & usef & ease & task & expl & Cons \\
\hline $\begin{array}{l}\text { "Low work } \\
\text { autonomy" group } \\
\text { of users (N=47) }\end{array}$ & -.12 & .13 & $.31^{*}$ & $.42^{* *}$ & .12 & .13 & $.36^{*}$ \\
\hline $\begin{array}{l}\text { "High work } \\
\text { autonomy" group } \\
\text { of users } \\
\text { (N=60) }\end{array}$ & -.18 & .12 & $.33^{* *}$ & $.36^{* *}$ & -.09 & -.13 & .24 \\
\hline
\end{tabular} \\
\hline
\end{tabular}

mov = appropriation moves; faith = faithful appropriation; usef = perceived usefulness; ease = perceived ease of use; task = task-oriented use; expl = explorative use; cons = consensus on appropriation

\section{Table 8.11 Correlation between the level of appropriation and work process effectiveness in groups which experienced high and low levels of work autonomy}

Overall, the relationship between the level of appropriation and the level of work process effectiveness is most positive among users with a low level of work autonomy, although the difference between the two groups is not that large. Theoretically, we expected the opposite. Our explanation for this opposite result is that users who have low work autonomy are in general more 'stuck' to the office technology for their daily work. The content of their job is limited and probably more focussed on working with the office technology than users with a high level of work autonomy. Users who have a high level of work autonomy will probably have the possibility to choose whether to work with the technology or to carry out other tasks. In their work they are unlikely to be as dependent upon the office technology as users with a low level of work autonomy. Thus, appropriating the office technology has a stronger impact on work process effectiveness among users with a low level of work autonomy.

It is noticeble that the relationship between the level of consensus on appropriation and work process effectiveness is more positive among users with a low level of work autonomy than among users with a high level of work autonomy. Understanding the situation in which our respondents operated, provided an explanation. Users with a low level of work autonomy are in general more 'mutually dependent' for their daily work. Each user carries out small limited tasks. Being more dependent on the office technology means that the level of consensus on how to work with the office technology, among users with 
a low level of work autonomy, impacts more strongly on the level of work process effectiveness. Overall, we conclude that hypothesis $3 \mathrm{~b}$ is not confirmed.

Having tested all the additional hypotheses, a summary of the findings will be given in the next section.

\subsection{Summary of findings}

To summarize, by placing the four office technology projects alongside each other we observed that all the projects started with a hard approach to technology development. In two cases, the management switched to a softer approach, after realizing quite late that their projects risked failure.

The contribution of the management in the all four office technology projects predominantly consisted of emphasizing performance contribution issues. Organizational environment and human issues were scarcely stressed. The same applied to the contribution by the IT experts, although in two of the four cases they where the ones to consider human issues after the project process did not develop smoothly.

In general users were poorly involved in the four office technology projects. If they were involved, it was mainly by representatives and mainly as information providers, not as decision-makers.

The spirit of the office technologies developed and implemented in three of the four projects can be characterized as control-oriented. In other words, the intent underlying the technical features of these office technologies was to control the primary process. The technical features of the technologies in general were highly restrictive, low to moderately sophisticated and low to moderately comprehensive. Users appropriated the office technologies to a moderate to high extent. In none of the four projects did users completely reject the technology.

Regarding the contextual factors of office technology appropriation, we observed that, overall, the level of organizational change was low. Furthermore, the level of work autonomy, the satisfaction with the implementation process, the satisfaction with the organizational support, and support of the reasons for implementation were low to moderate. The outcomes of the projects in general reflect a moderate level of work process effectiveness following new office technology implementation. In general, the projects brought about a moderate to high level of unanticipated change, and exceeded their budgets and time schedules by far.

The results from testing the hypotheses clearly show that user involvement contributes positively to the clarity of an office technology's spirit to users. Even though, from the individual office technology projects, we did learn that there are other channels through which users can "get the spirit". For instance, participating in testing of the technology, training sessions, manuals, 
and informal communication among users can contribute to clarifying the spirit of an office technology.

Overall, the clarity of the spirit is positively related to the level of appropriation. The clearer the spirit is to users, the more faithful they appropriate the office technology, the more they perceive the technology as useful and easy to use, and the more they use the technology in a task-oriented way. In particular, contextual factors such as the extent to which users agree upon the reasons for new office technology implementation, the extent to which users are satisfied with the organizational support during office technology appropriation, and the level of internal organizational change that accompanied the project influence this relationship. The last of these, however, influences this relationship in the opposite way to that expected. A low level of internal organizational change does support users who experience the spirit of the office technology as clear to appropriate the office technology to a high level. Overall, the clarity of the spirit influences the level of appropriation of the office technology positively, if users agree upon the reasons for its implementation, if the organizational support is good, or if the level of internal organizational change is low.

Finally, overall, only the level of perceived usefulness, perceived ease of use, and consensus on appropriation are significantly positively related to work process effectiveness. With the other aspects of appropriation this was not the case. Notably, contextual factors such as the level of organizational change and the level of work autonomy explain to a limited extent this limited relationship, but in the opposite way to that expected. Office technology appropriation contributes to work process effectiveness especially among users who experience a low level of organizational change and a low level of work autonomy. This outcome can most reasonably be explained by the fact that most of the organizational changes in our four projects were unanticipated, and thus might have meant an extra stress factor for users. Furthermore, users with a high level of work autonomy probably had alternatives to working with the office technology, while users with low work autonomy probably had no choice but to use the office technology in order to carry out their tasks. Therefore, appropriation of an office technology has more influence on the level of work process effectiveness among this latter group of users. It is likely that contextual factors such as users' satisfaction with organizational support during appropriation and users' satisfaction with the implementation process also influence in the relationship between office technology appropriation and work process effectiveness. These were not identified as such in the research model as presented in chapter two.

\section{Improving the research model}

Having analyzed the case studies and summarized the main findings we should now reflect on the research model. The most immediate question is: what are the consequences of the findings for this model? Having tested the 
hypotheses about the relationships between the concepts of our research model, we know whether they are related and to what extent. Furthermore, from the explanations sought for unexpected results we have found additional features that could improve the research model. These are included in the improved research model presented in Figure 8.3. 


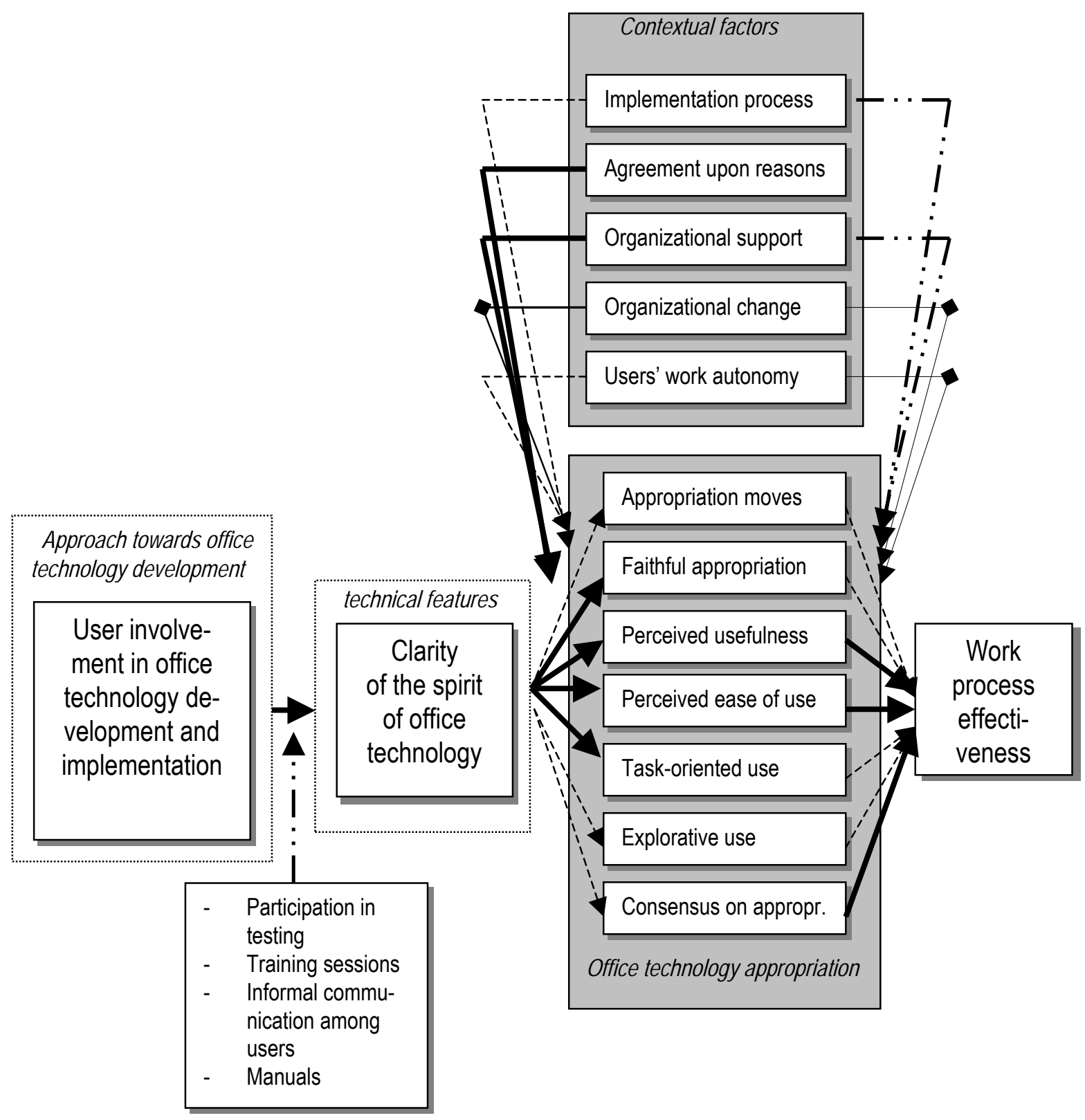

Figure 8.3 The adapted research model 


\section{Meaning of arrow styles}

Thick line $=$ positive, significant relationship

Dotted line Marked line $=$ unconfirmed relationship

Dot-Dash line $=$ relationship is opposite to that expected = suspected relationship, based upon results

Our initial research model, presented in chapter two, was based upon adaptive structuration theory (AST). Inspired by AST we proposed that the effects of office technology are a result of office technology use rather than a result of its technical characteristics. Office technology is 'realized' during use. Expected effects arise only if office technologies are used in accordance with the intents and goals underlying the technical features. These intents and goals, or in other words the non-technical side of office technology is referred to as its spirit. The process of 'realization' is referred to as office technology appropriation. In order to 'realize' an office technology in line with its spirit, users must experience this spirit as clear. That was one of our basic hypotheses. The right way to make this spirit clear to users is to, involve them in the process of development and implementation was another of our basic hypotheses. Our final basic hypothesis was that the better users 'realize' an office technology, the more this will contribute to work process effectiveness. Additionally, we acknowledged that office technologies are implemented and used in a context, and that this might impact on the hypothesized relationships.

Reflecting on this theoretical point of departure, in the light of the results of our study, leads us to conclude that the basic approach of the research model is valid. The first two hypotheses are confirmed, but it has become clear that certain contextual factors play a more dominant role than others, and some play a role in the opposite way to that expected. The third hypothesis was not confirmed but we provided explanations for this. In the next and final chapter we will draw to conclusions and discuss their implications for practice and theory. 


\section{Nine}

\section{Conclusions and recommendations}

\subsection{Introduction}

We started this study with the central research question formulated in chapter one: How can office technology projects be improved by the use of the concepts of the spirit of office technology and office technology appropriation? This question was inspired by the notion that a considerable number of efforts to introduce information technologies in offices have been unsuccessful. In this final chapter we will draw conclusions and discuss their implications. The remainder of this chapter is divided into two sections: in the next section the results of our study will be discussed in terms of guidelines to improve office technology projects. We will raise six issues and spend a subsection on each separate issue. Following this the final section will propose an agenda for further research.

\subsection{Discussing office technology projects}

In chapter 4 to 7 we discussed the case studies, which concerned office technology projects. In chapter 8 we placed the cases alongside each other in order to obtain an overall view. Based upon this analysis we raise six issues, which we believe should be taken into consideration in order to improve office technology projects. Each of the following subsections discusses one issue.

\subsubsection{From technology-driven towards technology use- centered projects}

A first conclusion that can be drawn from the office technology projects studied is that office technology projects still seem to be IT-driven events. The focus in the projects is on developing the technical features of the office technology and what they should bring about. Primarily, new office technologies are expected to contribute to the performance of an organization. In particular the management, as well as the IT experts, stress the so-called performance contribution issues. That office technology should fit with the internal organizational environment in which it operates, or that office technologies should improve the work situation of users are not major concerns in the projects. In chapter one, based upon studies of Doherty and King (1998) and Clegg et al. (1997), we already noted that organizational and human issues are not well addressed. What we observed in the four projects included in this study 
confirms this observation. It is also consistent with the observation of Looise (1996) who notes that technological innovation (followed by economical innovation) still has a higher priority in companies than social innovation. Management and IT experts strongly believe that with the implementation of new, technically sound, office technology the recognized problems will be solved. In our view they are mistaken, and this is supported when we look at the project outcomes, which are generally disappointing.

In this study we concentrated on the non-technical side of office technologies, namely the intention underlying the technical features, which we labelled as the spirit of the office technologies. Only if office technologies are used in line with the underlying intention, can the expected effects arise. Therefore, technically sound office technologies on their own are not sufficient to solve the identified problems; the underlying intention must also be sound. Hence, a major issue we want to address in this thesis is that office technology projects should shift from being technology-driven events towards technology use - centered events. In use, office technology is 'realized', depending upon how it is used. If the spirit is clear to users, they can enable the expected effects to arise.

Shifting the focus from the office technology itself towards its use can contribute to the extensive discussion in the literature on the relationship between IT and business performance. The results of research on this topic are far from consistent (Hitt and Brynjolfsson, 1996; Pinsonneault and Rivard, 1998). A main cause of this inconsistency might be that much of the research assumes a direct causal relationship between IT and business performance. It ignores the process of IT use.

\section{Managing the clarity of spirit}

The results from testing our hypotheses indicate that the clarity of an office technology really does make a positive difference in terms of office technology appropriation. In other words, the non-technical side of office technology is an essential factor and has to be reckoned with. Since office technology is 'realized' when it is used, it is critical that users experience the intents and goals of an office technology as clear. Even more strongly put, these intents and goals should be their own. Therefore developing the intents and goals should at least be a joint activity between users, IT experts and management. In practice, users are usually only involved after decisions about the initial intents and goals of new office technololgy have been made. It is not surprising then, that users find different intents and goals while appropriating a new office technology. The initial intents and goals may well not be the same as theirs. In our view, office technology projects would be improved if it is taken into consideration that developing and implementing new office technology means developing and 
implementing a 'joint belief' in the intents and goals of the technical features, and in the way to achieve these intents and goals.

\subsubsection{From a control-oriented spirit towards a support- oriented spirit}

The observation that most office technologies in the projects studied contained a spirit aiming to control the primary process makes it clear that a fundamental belief is that the performance of an organization can be enhanced by placing limitations on user behavior, rather by facilitating or supporting it. Against the background of the previous remarks this is not surprising. However, if we compare this position with the outcomes of the projects, it is certainly possible that this explains to an extent why the work process effectiveness in all of the cases was disappointing, and why the projects had led to considerable unanticipated changes. It is likely that a control-oriented spirit did not really represent what was required in the units involved. The technical features offered to users also reflected the intention to control. As noted, in most cases, the features were restrictive, and not very sophisticated and comprehensive. It suggests that users were poorly facilitated.

Based upon the findings from our four case studies we believe that developing and implementing office technologies with the intention of achieving a higher level of control over the work processes is unlikely to work. It is probable that users will find ways to act so that the technology will meet their demands. Users will work with certain features in ways other than expected, or will even reject certain features, if they are unable to make any sense out of these features in relation to their own perception of their situation. We saw examples of this in three of the four cases where the spirit of the office technology was control-oriented. In unit A users continued to work with paper to a certain extent eventhough the intention of the new office technology was to create a paperless office. In unit B users 'committed acts of sabotage' by ignoring certain financial risk management rules. In unit $D$ most users continued working with a paper calendar, considering this as their definitive calendar, despite having the new electronic calendar at their disposal. Not being prepared for 'deviant' use is the main 'cause' of unanticipated changes resulting from newly implemented office technologies. Therefore, office technologies should not 'carry' a control-oriented spirit, but a supportive, facilitating spirit in order to be more successful.

\subsubsection{From neglected users towards responsible users}

Users are poorly involved in office technology development and implementation, although management and IT experts do believe that they 
involve users to quite an extent. However, if we look at the actual user involvement activities, we conclude that users virtually always just play the role of information providers about the current situation in the organization. They very rarely have formal decision-making responsibilities and the actual involvement is limited to only one, or just a few user representatives. The observation that users are poorly involved is disappointing since there is a broad range of different IT development methods available in the literature. These include methods that are very user-driven. Examples of such methods are ETHICS (Mumford, 1983, 1993), Scandinavian design (Ehn, 1993), and the evolutionary design approach (Eason, 1982). However, not all of these methods are ideal because, albeit placing the user in a more central role, they can still be very technique-oriented.

In the previous chapter we noted that users who were involved during office technology project implementation find the system's spirit clearer than users who were not involved. However, besides being involved during the system development and/or implementation, there are other ways of becoming acquainted with the spirit of a new system, for example, user training sessions, manuals, and immediate support from system managers or other experts during the use of an office technology. Another way of 'getting the spirit' of an office technology can be the informal interaction among users as a result of participation in test sessions. In the projects studied, testing the technology was an event in which users were usually involved in order to find out whether the technology really functioned or not. As in three of the four projects these tests were unsuccessful (which was one causes of the extra delays), quite some discussion arose between users who were involved and those who were not involved. These discussions may have been good opportunities to communicate (implicitly or explicitly) the spirit of an office technology. However, it is disappointing that the spirit of an office technology has to 'reach' future users through such informal channels. Users are at the centre of making office technology projects succeed and they are able to carry the responsibility for this. A necessary pre-condition is that users are taken seriously and must at least be committed to the intents, goals and values of an office technology to be introduced.

\subsubsection{From neglecting organizational change towards preparing for unanticipated organizational change}

In general, office technology projects are not accompanied by a high level of anticipated internal organizational change. We believe that this is another cause of the disappointing project outcomes. Already in 1964, Leavitt expressed his belief that changing one of the organizational components, structure, tasks, people, or information technology, was inextricably linked to changing other components. Implementing office technologies is about influencing human 
behavior within an organizational context, and therefore the latter cannot be ignored in office technology projects.

Surprisingly, a high level of internal organizational change during an office technology project does not support the relationship between the clarity of the spirit and the level of appropriation in a positive way. In our view, organizational change leads to extra confusion among users (especially if it is quite unexpected, as was the case in the projects in this study) and constrains them in trying to appropriate a new office technology. This would suggest that, in office technology projects, the level of organizational change should be minimized. This is not what we propose however! A similar thought comes from the observation that a clear spirit is more positively related to the level of appropriation among users who have a low level of work autonomy than among those who have a high level of work autonomy. Thus, having more options when carrying out the day-to-day tasks way does not support users, who find the spirit of an office technology clear, to appropriate it to a higher extent. The office technologies included in this study seemingly match low work autonomy jobs better. This might also suggest that it is better to keep the level of users' work autonomy low because this will be supportive to the way in which they appropriate the office technology. This is not our view. What we should learn from this result is that it shows once again that office technology use is very much interrelated with the internal organizational context in which it takes place. Office technology development and implementation are events that cannot ignore their interrelationship with the internal organizational environment.

It should be acknowledged, that developing and implementing new office technology in practice implies organizational change. Above all, it should be acknowledged that organizational change can only be anticipated to a limited extent. To a considerable extent organizational change, resulting from office technology development and implementation, occurs as office technology is used, and therefore cannot be anticipated. What remains is preparing to deal with unanticipated change.

\subsubsection{From technical installion of office technology towards managing office technology appropriation}

Based upon the office technology projects studied we conclude that the results indicate that the quality of the implementation process and the organizational support during appropriation are moderate, in the view of the users. We can also conlude that users are not highly enthusiastic about the reasons for new office technology implementation. The office technology projects included in our study suggest that there is much to improve in practice because an adequate implementation process, adequate support for users during office technology appropriation, and users' commitment to the reason for implementing 
new office technology, are necessary preconditions for effective management of office technology appropriation. Many literature sources assume a direct relationship between user training, users' support and information system use (Leone and Matarazzo, 1998). We continue in this line of thinking and emphasize it even more.

Office technology use is more than only having users push buttons. Office technology use is a matter of appropriation, as we elaborated in the first three chapters. The quality of what might seem just additional factors in office technology projects influence the extent to which users appropriate new office technologies. Managing office technology appropriation needs to ensure that users will be committed to the spirit of an office technology. The results convincingly indicated that users who agree with the reasons for new office technology implementation appropriate it to a higher extent, provided they experience the spirit as clear. This supports our earlier suggestions on the roles of users in office technology projects: office technology use should be the main focus. Consequently, users should play the central role in office technology projects. Furthermore, a satisfactory way of implementing the office technology is one that especially supports users who experience the spirit of the office technology as clear in using it in line with this spirit. Good organizational support during office technology appropriation also makes a positive difference in the relationship between the clarity of the spirit and the level of appropriation.

Office technology implementation does not end when the technical installation is finished. This is only the start of the implementation process; the process has to support users while they try to incorporate a new office technology into their day-to-day activities.

\subsubsection{From improving the work process with new office technology towards improving the work process through human resources}

The outcome of the office technology projects studied in terms to improvements of the work process effectiveness, were moderate. A considerable time after new office technology implementation the work processes were not judged to be highly effective. The results from the four projects even showed that appropriation of the office technology to a high extent is not sufficient to give a high level of work process effectiveness. This is an interesting result. We know from the separate project descriptions that the office technology in three of the projects was considered to be the main 'instrument' for users in carrying out their day-to-day tasks. In other words, if incorporating the new office technology into users day-to-day activities did not make that much difference in work process effectiveness, what else would? In our view, the results make one thing clear. The internal organizational environment in which office technology is used is of 
major importance in terms of improving work process effectiveness using the newly implemented office technologies. Therefore, we would decrease the high expectations of office technology if improving the effectiveness of the work processes is all that is at stake. Improving the effectiveness of the work processes is in the first place a matter of influencing human behavior and human interaction, reflected in the organizational structure, culture, and human resources. Office technology can only play a facilitating role. In terms of managing office technology projects we believe that ignoring the internal organizational environment is like leaving the engine out of an automobile!

\subsection{Directions for further research}

In this final section we hint at directions for further research. After all the topics that have been discussed there are quite a number of topics that call for further research. We will address what we see as the four most urgent ones.

First of all, what really caught the eye in the projects studied is that office technnology projects are still IT-driven. The non-technical side, the intention underlying the technology, is hardly acknowledged. The main question that arises after noting all this is why is the non-technical side not treated as an important aspect of IT projects? Maybe the answer lies in the project methods used. It is possible that project management uses tools that stress the technical/functional aspects of projects and this leaves less space for stressing organizational and human issues (for example user-input). The results from a study by Gasson and Holland (1996) support this view. Gasson and Holland found that, in more than three-quarters of the IT projects, automated or manual project scheduling tools are used. In Gasson and Holland's view, project management functions have so strongly become synonymous with scheduling and resource allocation that managers do not use tools to support other areas of responsibility such as facilitating and recording user-input to the development process. Gasson and Holland report that: "Even when asked to identify tools used for system development purposes, only one company reported using a tool which supported user-participation".

This reinforces previous findings in this area, which report that IT development is largely seen as a scheduling management problem and as a functional/technical responsibility." (1996, pp. 222). Walton and Vittori (1983) come to a similar conclusion. They observe that staff members are usually rewarded for completing systems on schedule, within budget, and according to original specifications.

The project management tools applied might thus be a reason for ignoring the non-technical side. Besides this, it is also possible that practitioners find that, in a market-economy, doing business is mainly a question of being able to gain and hold onto a market share, and that IT-driven approaches seem the most 
attractive since they look the least complicated to apply. This, however, is not an acceptable view after decades of disappointing information technology implementations in office environments. In chapter one we saw that a major reason for office technology project failure is that they are too IT-driven. In our study this was confirmed. One could expect that a change would have been made "somewhere along the way". Therefore the question is why has it not? More research is needed to find out the reasons why it is so hard in practice to apply less IT-driven approaches in office technology development and implementation. Further research on this topic could help organizations to make a switch.

Secondly, the results of this study support our belief that the non-technical side of office technology is an essential element in determining how to improve office technology projects. In other words, the non-technical side of office technology is again addressed here. Now it is a matter of developing ways to include this issue in office technology projects. As emphasized in one of our main conclusions, in our view, office technology projects clearly need to place the user in a central role. Despite the available methods in the literature, new research needs to start from the assumption that office technology is 'realized' as it is used. This research should result in new methods and approaches for office technology development and implementation.

Thirdly, a topic for further research in our view is project management. We noted that one of the reasons for the limited scope of office technology development and implementation, in practice, can be the project management tools used. They seem to be very much budget and time schedule oriented, and leave little less space for addressing non-technical issues. In general, project management has a poor theoretical basis, it is poorly empirically funded and quite normative. An interesting exception is an empirical study on project management by Van Aken (1996). A major outcome of his study is that project success is not primarily dependent upon the use of management instruments such as planning, budgetting, and monitoring, and formal documents. More important factors are the attitude and style of team managers, and the way team managers apply the mix of style and instruments. Further research on project management should be directed at increasing the understanding of project management practices, and developing project management approaches that put less emphasis on planning and budgetting.

Last, but not least, new research should be carried out based upon the theory used in developing our research model, namely adaptive structuration theory. In this study we used concepts from this theory to test the relationships between certain concepts. We studied whether the concept of spirit makes a difference in office technology appropriation, and to what extent. One of the consequences of our findings from our theoretical framework is that the concept of spirit may need refining. As noted in chapter 8 , in none of the cases did users 
completely reject an office technology (although in three cases the testing of the office technology was so problematic that users were not able to work meaningfully with the features offered. Consequently, many improvements had to be made before the final implementation of the technology). In other words, users were seemingly always able to make some sense out of the technical features implemented. If they did not clearly experience the 'official' spirit, they probably tried to determine the technology's spirit whilst appropriating the technology. Theoretically this is an interesting aspect of the concept of spirit, which we did not stress in chapter two. However, we propose that the spirit of an office technology should be considered as flexibly interpretive, to use Orlikowski's (1991) words. Users interpret the technical features in such a way that the features make at least some sense to them in any given situation, provided that they want to. Therefore, the spirit can change as the office technology is appropriated. This dynamic characteristic of the concept of spirit can explain why users, in all the case studies at least attempted to use the technology, although in general they were poorly involved, the technical features were highly restrictive and neither sophisticated nor comprehensive, and users in general were not satisfied with the implementation process itself.

New research should be of a more interpretive nature and start from the view that the concept of spirit is dynamic, or in other words, flexibly interpretable. We expect that conceiving the spirit in this way will provide a fruitful basis for a deeper understanding of the interaction between office technology and its users. Adaptive structuration theory offered a valuable basis for deepening our understanding, but humans will continue to develop new technologies. This recalls the opening passage of chapter one in which, in 1899, the Commissioner of the United States Office of Patents expressed the view that everything that can be invented has been invented. We do not agree with him. Therefore, new concepts will be needed to understand the reality we perceive. 


\section{References}

Aken, T. van, (1996). De weg naar project succes [The way to project success]. Maarssen: Elsevier/De Tijdstroom

Applegate, L.M. (1999). In search of a new organizational model: Lessons from the field. In G. DeSanctis \& J. Fulk (Eds), Communication technology and organizational forms, (33-70), Berkely, CA: Sage Publications

Barki, H. \& Hartwick, J. (1994). User participation, conflict, and conflict resolution: the mediating roles of influence. Information systems research, 5, 422-438

Barley, S.R. (1986). Technology as an occasion for structuring: evidence from observations of CT scanners and the social order of radiology departments. Administrative Science Quarterly, 31, 78-108

Bhaskar, R. (1979). The possibility of naturalism. Brighton: the Harvester Press

Berger, P. \& Luckmann, T. (1967). The social construction of reality. New York: Anchor Books

Bolman, L. \& Deal, T. (1984). Modern approaches to understanding and managing organizations. San Francisco: Jossey Bass Publishers

Bourdieu, P. (1977). Outline for a theory of practice. Cambridge: Cambridge university press

Centraal bureau voor de Statistiek: (http://www.statline.cbs.nl)

Chin, W., Gopal, A., Salisbury, W. (1997). Advancing the theory of adaptive structuration: the development of a scale to measure faithfulness of appropriation. Information Systems Research, 8, 343-367

Ciborra, C. (1996). Introduction: what does groupware mean for the organizations hosting it? In C. Ciborra (Ed), Groupware and teamwork (pp. 119). Chichester: John Wiley and sons 
Clegg, C., Axtell, C., Damodaran, L., Farbey, B., Hull, R., Lloyd-Jones, R., Nicholls, J., Sell, R., Tomlinson, C. (1997). Information technology: a study of performance and the role of human and organizational factors. Ergonomics, 40, $851-871$

Davis, F.D. (1989). Perceived usefulness, perceived ease of use, and user acceptance of information technology. MIS Quarterly, 13, 319-339

DeSanctis, G. \& Fulk, J. (1999). Conclusion; Research issues and directions. In G. DeSanctis \& J. Fulk (Eds), Shaping organization form; communication, connection, and community (pp. 497-502). Thousand Oaks, Calif.: Sage Publications

DeSanctis, G., Poole, M.S. (1994). Capturing the complexity in advanced technology use: adaptive structuration theory. Organization Science, 5, 121-147

Doherty, N.F. \& King, J.P. (1998). The consideration of organizational issues during the systems development process: an empirical analysis. Behaviour \& Information Technology, 17, 41-51

Eason, K. (1982). The process of introducing information technology. Behaviour and information technology, 1, 197-213

Economist, the, (2000) A survey of the new economy, vol. 356, no. 8189, September 23rd

Ehn, P. (1993). Scandinavian design: on participation and skill. In D. Schuler \& A. Namioka (Eds), Participatory design; principles and practices, (pp. 41-77). Hillsdale (NJ): Lawrence erlbaum associates

Ernst \& Young (2001). Trends in ICT 2001. Maarssen: Ernst \& Young ICT Leadership

Ewusi-Mensah, K. \& Przasnyski, Z. (1991). On information systems project abandonment: an exploratory study of organizational practices. MIS Quaterly, $15,67-85$

Ewusi-mensah, K. \& Przasnyski, Z.H. (1994). Factors contributing to the abandonment of information systems development projects. Journal of Information technology, 9, 185-201 
Fitzgerald, G. (1998). Evaluating information systems projects: a multidimensional approach. Journal of Information technology, 13, 15-27

Francalanci, C. \& Galai, H. (1998). Information technology and worker composition: determinants of productivity in the life insurance industry. Management Information Systems Quarterly, June, 227-241

Franke, R.H. (1987). Technological revolution and productivity decline: computer introduction in the financial industry. Technological forecasting and social change, $21,143-154$

Fulk, J. \& DeSanctis, G. (1999). Articulation of communication technology and organizational form. In G. DeSanctis \& J. Fulk (Eds), Shaping organization form; communication, connection, and community (pp. 5-32). Thousand Oaks, Calif.: Sage Publications

Gasson, S. (1994). Managing organizational change: The impact of information system development methods. In N. Jayaratna, G. Paton, Y. Merali, \& F. Gregory (Eds), Proceedings of the conference of the BCS Information Systems Methods Specialist Group, Heriot-Watt University, Edinburgh, September 1994

Gasson, S. \& Holland, N. (1996). The nature and processes of IT-related change. IFIP 8.2 working conference on Information technology and changes in organizational work 1995, 213-234

Giddens, A. (1979). Central problems in social theory: action, structure and contradiction in social analysis. Berkeley CA: University of California Press

Giddens, A. (1982).Sociology: a brief but critical introduction. London: McMillan

Giddens, A. (1984). The constitution of society: outline of the theory of structure. Berkeley CA: University of California Press

Giddens, A (1984b). Structuratietheorie en empirisch onderzoek [Structuration theory and empirical research]. In Q. Munters, G. Spaargaren (Eds) Gastcollege van Anthony Giddens uitgesproken te Wageningen op 27 april 1984

Heller, F., Pusic, E., Strauss, G., Wilpert, B. (1998). Organizational participation; myth and reality. Oxford: Oxford University Press 
Hertog, F. den, \& Sluijs, E. van (1995). Onderzoek in organisaties; een methodologische reisgids [Research in organizations; a methodological route guide]. Assen: Van Gorcum

Hirschheim, R. (1983). Assessing participative systems design: some conclusions from an exploratory study. Information and management, december

Hirschheim, R.A. (1985). Office automation; a social and organizational perspective. Chichester: John Wiley \& Sons

Hornby, P., Clegg, C., Robson, J., Maclaren, C., Richardson, S., O'Brien, P., (1992). Human and organizational issues in information systems development. Behaviour \& information technology, 11, 160-174

Hunton, J. \& Beeler, J. (1997). Effects of user participation in systems development: a longitudinal field experiment. MIS Quarterly, December, 359-383

Hutjes, J.M. \& Buuren, J.A. van (1992). De gevalsstudie: strategie van kwalitatief onderzoek [The case study: strategy for qualitative research]. Meppel: Boom/Open Universiteit

livari, J., Hirscheim, R., Klein, H. (1998). A paradigmatic analysis contrasting information systems development approaches and methodologies. Information systems research, 9, 164-193

Irving, R.H. \& Higgins, C.A. (1991). Office information systems; management issues and methods. Chichester: John Wiley \& Sons

Jayaratna, N. (1995). Understanding and evaluating methodologies, NISAD: a systematic framework. Maidenhead: McGraw-Hill

Johansen, R. \& Swigart, R. (1994). Upsizing the individual in the downsized organization. New York: Addison-Wesley

Kaarst-Brown, M. \& Robey, D. (1999). More on myth, magic and metaphor. Information technology \& people, 12, 192-217

Kahai, S.S., Sosik, J.J., Avolio, B.J. (1997). Effects of leadership style and problem structure on work group process and outcomes in an electronic meeting system environment. Personnel psychology, 50, 121-146 
Larsson, R. \& Lowendahl, B. (1996). The qualitative side of management research. Paper presented at the annual meeting of the Academy of Management, Cincinnati, $\mathrm{OH}$

Latour, B. (1987). Science in action: how to follow scientists and engineers through society. Cambridge, Mass.: Harvard University Press

Lawrence P. \& Lorsch, P. (1976). The differentiation and integration model. In W. Bennis, The planning of change, New York: Holt, Rinehart and Winston

Lee, T. W. (1999). Using qualitative methods in organizational research. Thousands Oaks, CA.: Sage

Leone, L. \& Matarazzo, G. (1998). Predicting the use and effectiveness of an office automation system (OAS); a case study. Behaviour and technology, 17, $361-371$

Lin, W. \& Shao, B. (2000). The relationship between user participation and system success: a simultaneous contingency approach. Information \& management, 37, 283-295

Looise, J.C.(1996). Sociale innovatie moet, maar hoe? [Social innovation is necessary, but how?] Oratie, Enschede: Universiteit Twente

Lyytinen, K. \& Hirscheim, R. (1987). Information systems failures - a survey and classification of the empirical literature. Oxford surveys in information technology, 4, 257-309

Maxwell, J.A. (1996). Qualitative research design. Thousand Oaks, CA.: Sage

Majchrzak, A., Rice, R.E., Malhotra, A., King, N., Ba, S. (2000). Technology adaptation: the case of a computer-supported inter-organizational virtual team. MIS Quarterly, 24, 569-600

Morgan, G. (1986). Images of organizations. Beverly Hills: Sage publications

Mumford, E. (1993). The participation of users in systems design: an account of the Origin, Evolution, and use of the ETHICS method. In D. Schuler \& A. Namioka (Eds), Participatory design; principles and practices, (pp. 257-270). Hillsdale (NJ): Lawrence erlbaum associates 
Mumford, E. (1983). Participative systems design: practice and theory. Journal of occupational behaviour, 4, 47-57

O'Brien, J. (1995). Leerboek IT-toepassingen in de informatieverzorging [Introduction to information systems]. Schoonhoven: Academic service

Ollman, B. (1971). Alienation: Marx's conception of man in capitalist society. Cambridge: Cambridge University Press

Orlikowski, W. (1991). The duality of technology: rethinking the concept of technology in organizations. Massachusetts Institute of technology, CISR Working paper no. 219, CISR. Sloan School of Management, Massachusetts Institute of technology, January

Orlikowski, W. \& Baroudi, J. (1991). Studying information technology in organizations: research approaches and assumptions. Information systems research. 2, 1-28

Orlikowski, W. \& Robey, D. (1991). Information technology and the structuring of organizations. Working Paper No. 220, CISR. Sloan School of Management, Massachusetts Institute of technology, March

Orlikowski, W. (2000). Using technology and constituting structures: a practice lens for studying technology in organizations. Organization science, 11, 404-428

Panko, R.R. (1984). Office work. Office: technology and people, 2, 205-238

Pinsonneault, A. \& Rivard, S. (1998). Information technology and the nature of managerial work: from the productivity paradox to the Icarus paradox? MIS Quarterly, September, 287-308

Poole, M.S.\& DeSanctis, G. (1992). Micro-level structuration in computersupported group decision-making. Human communication research, 19, 5-49

Poole, M.S. \& DeSanctis, G. (1990). Understanding the use of group decision support systems: the theory of Adaptive Structuration. In J. Fulk, \& C. Steinfield, (Eds) Organizations and communication technology, (pp. 173-193), Newbury Park/London/New Delhi: Sage Publications

Poole, M.S. \& DeSanctis, G. (1989). Use of group decision support systems as an appropriation process. Proceedings of the $22^{\text {nd }}$ Annual Hawaii International Conference on System Sciences, (pp. 149-157). New York: ACM 
Riesewijk, B. \& Warmerdam, J. (1988). Het slagen en falen van automatiseringsprojecten [The success and failure of automization projects]. Nijmegen: ITS

Robey, D. (1996). Research commentary: diversity in information systems research: threat, promise, and responsibility. Information systems research, 7 , 400-408

Robey, D. \& Boudreau, M. (1999). Accounting for contradictory organizational consequences of IT. Information systems research, 10, 167-185

Roessner J.D., Mason, R.M., Porter, A.L., Rossini, F.A., Schwartz, A.P. (1985). The impact of office automation on clerical employment, 1985-2000. Westport, Conn.: Quorum books

Ruel, H.J. M. (2000). Reconsidering our team effectiveness models: a call for an integrative paradigm. In M.M. Beyerlein, D.A. Johnson, S.T. Beyerlein (Eds). Advanced in interdisciplinary studies of work teams (vol.7), (pp. 173-185). New York: Jai Press/Elsevier science

Ruel, H.J.M. (2001). Getting the spirit of office technologies! Does the internal organization environment support or constrain? Proceeding of Information resource management association international conference, (pp. 1168-1174). Hershey: Idea group publishing

Ruel, H.J.M. (forthcoming). The non-technical side of office technology, in: E.J. Szewczak \& C.R. Snodgrass (Eds.) Managing the human side of information technology: challenges and solutions, Hershey: Idea group publishing

Sambamurthy, V. \& Chin, W.W. (1994). The effects of group attitudes towards GDSS designs on the decision-making performance of computer-supported groups. Decision Science, 25, 215-241

Touraine, A. (1973). De post-industriele maatschappij: geboorte van een geprogrammeerde samenleving (translated from French) [The post-industrial society: birth of a programmed society]. Baarn: H.Nelissen

Vadapalli, A. \& Mone, M. (2000). Information technology project outcomes: user participation structures and the impact of organization behavior and human resource management issues. Journal of engineering and technology management, 17, 127-151 
Walsham, G. (1993). Interpreting information systems in organizations. Chichester: John Wiley \& Sons

Walsham, G. (1995). The emergence of interpretivism in IS research. Information systems research, 6, 376-394

Wheeler, B., Mennecke, B.E., Scudder, J.N. (1993). Restrictive group support systems as a source of process structure for high and low procedural order groups. Small group research, 24, 504-522

Website The Economist: www.economist.com

Yin, R.K. (1994). Case study research: design and methods (2nd ed.). Thousand Oaks, CA.: Sage

Zaal, R. (2000). Macro-economische verdiensten IT nog steeds onduidelijk [Macro-economic benefits of IT still unclear]. Automatiseringsgids, 34, 1 


\title{
Samenvatting/Summary
}

\author{
Inleiding: Waar gaat de studie over?
}

Dit proefschrift is een verslag van een studie naar de wijze waarop projecten gericht op de ontwikkeling, implementatie en het gebruik van informatietechnologie (IT) in kantooromgevingen kunnen worden verbeterd. We noemen deze projecten in het Engels kortweg office technology projects, maar hanteren hier verder de Nederlandse bewoordingen IT projecten in kantoren, of kortweg IT projecten.

Informatietechnologie is een niet meer weg te denken verschijnsel in kantooromgevingen. Met enige regelmaat wordt in kantooromgevingen besloten om een project te starten ten behoeve van de vervanging van een bestaand IT systeem door een beter en nieuwer systeem. Echter, het succes van deze zogenoemde IT projecten in kantoren is op zijn zachts gezegd nogal wisselend te noemen. Het aantal IT projecten dat mislukt is aanzienlijk, maar zelfs een groot deel van de IT projecten dat uiteindelijk wel als geslaagd wordt bestempeld, had 'onderweg' vaak de nodige problemen. Veelal komt er uit IT projecten niet datgene wat verwacht wordt. De vraag is: hoe komt dat? De literatuur geeft een groot scala aan redenen. Zo worden genoemd: gebrek aan een goede bedrijfsstrategie, gebrek aan gebruikersinbreng, gebrek aan training van gebruikers, en gebrek aan aandacht voor de interne organisatie (de organisatiestructuur, cultuur, en mensen) en de directe werkplek van de eindgebruiker. Naar onze mening komen al deze redenen voort uit de eenzijdige opvatting over IT, namelijk dat het voornamelijk iets technisch, statisch, tastbaars en zichtbaars is. Er wordt voorbijgegaan aan de niet-technische zijde van IT, de subjectieve zijde.

De opdracht die we in deze studie op ons hebben genomen is om op basis van deze invalshoek te bezien welke richtingen kunnen worden aangegeven om IT projecten in kantooromgevingen te verbeteren.

\section{Theoretisch kader: Met behulp van welke bril is de studie uitgevoerd?}

Sinds de opkomst van IT, vanaf de jaren zestig, zijn er veel theoriëen en benaderingen ontwikkeld om de ontwikkeling en implementatie van IT beter te begrijpen en te verbeteren. Tot en met het midden van de jaren tachtig van de vorige eeuw zijn deze hoofdzakelijk gebaseerd op twee filosofische denklijnen, het technologisch determinisme en het technologisch voluntarisme. Beide denklijnen wisselen elkaar af in de mate waarin ze in de literatuur de boventoon 
voeren, doch het technologisch determisme drukt het belangrijkste stempel. In de tweede helft van de jaren tachtig van de vorige eeuw ontstaan er theoretische benaderingen die trachten de twee genoemde denklijnen te verbinden. Een belangrijke voedingsbodem voor deze benaderingen is het werk van de Engelse socioloog Anthony Giddens. Zijn structuratietheorie, die determisme en voluntarisme tracht te synthetiseren, zet IT-onderzoekers er toe aan te komen tot nieuwe vertrekpunten voor onderzoek. Twee Amerikaanse onderzoekers, Gerardine DeSanctis and Marshall Scott Poole, gebruiken Giddens' structuratietheorie om een theorie te ontwikkelen voor het bestuderen van groepen die werken met electronische groepsbesluitvormingssytemen. Deze theorie, Adaptive Structuration Theory, is voor ons in deze studie de basis om de niet-technische zijde van IT in kantooromgevingen te belichten.

Volgens Adaptive Structuration Theory (AST) bestaat IT niet alleen uit het technische, zichtbare en tastbare, maar draagt het ook een intentie in zich, in het Engels de spirit. In het vervolg van deze samenvatting blijven we de Nederlandse term gebruiken. De intentie van de IT is essentieel in het teweeg brengen van de verwachte effecten. Wil nieuw ingevoerde IT de verwachte effecten teweeg brengen dan moet de IT overeenkomstig de intentie gebruikt worden. Het gebruik van IT is dan ook niet alleen een vorm van 'het drukken op de knoppen' en 'klikken met de muis', maar een proces van toe-ëigening door de eindgebruiker, in het Engels aangeduid met de term appropriation. Hiermee bedoelen we dat gebruikers al interacterend met de technische onderdelen de IT 'incorporeren' in hun dagelijkse werkzaamheden en in dit proces de IT 'realiseren', ofwel maken tot wat het is. Kortom, in deze studie willen we afstand nemen van de gedachte dat de effecten van nieuwe IT een functie zijn van de mate waarin de IT technisch goed in elkaar steekt, maar starten we vanuit de gedachte dat effecten van nieuwe IT ontstaan in de wijze waarop het daadwerkelijk wordt gebruikt.

Vanuit deze theoretische basis ontwikkelen we de gedachtenlijn dat eindgebruikers slechts dan overeenkomstig de intentie van de IT kunnen handelen als de intentie helder is voor hen. Dus de helderheid van de intentie van de IT voor de gebruiker lijkt een belangrijke factor te zijn voor de mate waarin de IT wordt toe-geëigend overeenkomstig de intentie. Of dit ook daadwerkelijk zo is toetsen we in de werkelijkheid. De vraag die vervolgens opkomt is, hoe kan de intentie van de IT overgebracht worden op de gebruikers? Het voor de hand liggende antwoord lijkt te zijn, door gebruikers te betrekken bij de ontwikkeling en implementatie van de IT. Ook dit toetsen we in de werkelijkheid. Verder rijst de vraag, wat is het gevolg van toe-ëigening van nieuwe IT in een kantooromgeving overeenkomstig de intentie? Hierop kan het algemene antwoord luiden: dan zal de effectiviteit van de werkprocessen verbeteren. Dit is de voorlaatste toets die we uitvoeren. De laatste toets behelst de rol van contextuele factoren rondom IT toe-ëigening, zoals de mate waarin de 
ontwikkeling en implementatie van de IT gepaard ging met veranderingen in de organisatie, of de mate waarin gebruikers de redenen voor de invoering van nieuwe IT in het kantoor onderschrijven.

\section{Onderzoeksmethode: Hoe is de studie uitgevoerd?}

De studie is opgezet als een reeks van gevalstudies met een kwantitatieve component. Dit houdt in dat we gegevens hebben verzameld in geselecteerde gevallen, uitgevoerd met behulp van kwalitatieve en kwantitatieve methoden. We verzamelden gegevens met behulp van mondelinge interviews, ondersteund met documenten en observaties ter plekke, en met behulp van een schriftelijke vragenlijst die is voorgelegd aan eindgebruikers van IT in een kantooromgeving. Met behulp van de mondelinge interviews, aangevuld met de analyse van documenten en observaties ter plekke hebben we de IT projecten beschreven in termen van de gekozen IT-ontwikkeling- en implementatiemethode, de bijdragen van het management en IT experts, gebruikersparticipatie, de intentie van de IT, de toe-ëigening van de IT, de contextuele aspecten, en de uitkomsten van de IT projecten. De schriftelijke vragenlijsten dienden ervoor om te toetsen in welke mate er sprake is van samenhang tussen de genoemde aspecten.

\section{De gevallen: Waar is de studie uitgevoerd?}

Voor de gegevensverzameling hebben we vier organisaties benaderd waarin of een IT-project is uitgevoerd of nog gaande was. We beschouwden een IT-project als een case. Drie van de geselecteerde IT-projecten vonden plaats in kantooronderdelen van profit-organisaties, een project in een kantooronderdeel van een non-profit organisatie. De IT systemen die werden ontwikkeld en geimplementeerd in de geselecteerde cases waren een digitaal archief in combinatie met een workflow management systeem, een callcenter agent systeem, een ziektekostenadministratiesysteem, en een electronische agenda. Per IT project lag het gemiddelde aantal gebruikers rond de 25 .

\section{De uitkomsten: Wat is er uit de studie naar voren gekomen?}

Uit de studie kwam naar voren dat alle vier IT projecten in kantooromgevingen gekenmerkt werden door een zogenaamde harde benadering met betrekking tot IT ontwikkeling en implementatie. Zowel het management als de IT-ers benadrukten hoofdzakelijk de bijdrage die de nieuwe IT moest gaan leveren aan de prestaties van de organisatie. Veel minder aandacht kregen de organisatorische aspecten en de menselijke aspecten.

Gebruikers werden in beperkte mate betrokken in de IT projecten, veelal slechts door een vertegenwoordiger namens de hele gebruikersgroep. Deze 
persoon leverde doorgaans de informatie over de huidige manier van werken, maar had geen stem in de besluitvorming over het te ontwikkelen systeem.

De IT in de bestudeerde projecten droeg in drie van de vier gevallen een op 'control'-georiënteerde intentie in zich. Met andere woorden, de intentie van de geimplementeerde IT was in deze gevallen het verkrijgen van meer controle op het primaire proces. De mate waarin gebruikers zich de IT toe-ëigenden lag gemiddeld behoorlijk hoog. Dit was ondermeer te verklaren vanuit het feit dat voor veel gebruikers de nieuw geimplementeerde IT het basisinstrumentarium was om het dagelijkse werk te verrichten.

De IT projecten gingen nauwelijks gepaard met geplande veranderingen in de organisatie. Gebruikers waren weinig tot matig tevreden over het implementatieproces, de ondersteuning vanuit de organisatie tijdens het gebruik van de IT, en over de redenen voor implementatie van de nieuwe IT. Een tijd na de implementatie van de IT was de effectiviteit van de werkprocessen matig. Vanuit het gebruik van de nieuwe IT hadden zich in de vier IT projecten over het algemeen behoorlijk veel onverwachte veranderingen voorgedaan in de organisatie. Tot slot, alle vier IT projecten overschreden het budget aanzienlijk en duurden veel langer dan verwacht.

Uit de toetsing van de relaties tussen de kernaspecten van de gehanteerde theoretische uitgangspunten bleek dat gebruikers die betrokken zijn geweest in het ontwikkelings- en implementatieproces van de IT, de intentie van de IT als helderder ervaren dan gebruikers die niet betrokken zijn. Verder bleek dat gebruikers die de intentie van de IT als helder ervaren, de IT in sterkere mate toe-ëigenen dan gebruikers die de intentie niet als helder ervaren. Dit verband werd nog eens versterkt als gebruikers de redenen voor de implementatie onderschrijven, en als de ondersteuning vanuit de organisatie tijdens het gebruik goed is. Het verband tussen de helderheid van de intentie en de mate van toe-ëigening van de IT werd verzwakt indien gebruikers een hoge mate van verandering in de organisatie ondervonden. Dit was een opvallend resultaat omdat het suggereert dat de implementatie van nieuwe IT het best met zo min mogelijk organisatorische veranderingen gepaard kan gaan. Dit past niet in onze theoretische uitgangspunten. De verklaring voor dit onverwachte resultaat is hoogstwaarschijnlijk dat vooral het niet geplande karakter van de organisatorische veranderingen een 'verstorend' effect hebben op de relatie tussen de helderheid van de intentie van de IT en de mate van toe-ëigening.

Tot slot, een sterke mate van toe-ëigening van nieuwe IT door gebruikers leidde in de bestudeerde IT projecten niet zonder meer tot een verbetering van de effectiviteit van de werkprocessen. Dit is eveneens een wat onverwacht resultaat, echter het geeft naar onze mening ook aan dat toe-eigening van nieuwe IT alleen niet de werkprocessen kan verbeteren. De organisationele inbedding van die nieuwe IT is evenzeer van belang. Verder geeft dit resultaat mogelijk aan dat IT met de onderliggende intentie om meer controle te krijgen op 
het primaire proces, waarvan in drie van de vier IT projecten sprake was, niet de optimale oplossing was om het werkproces te verbeteren.

\section{En nu?}

Deze studie had tot doel voorstellen voor verbetering aan te reiken voor IT projecten in kantooromgevingen behulp van de gekozen theoretische insteek. Op basis van de resultaten uit de bestudering van de vier IT projecten komen we tot de volgende zes 'richtingaanwijzers'.

IT projecten in kantooromgevingen moeten minder techniek-gedreven zijn, maar meer focussen op de wijze van gebruik van IT. De vragen die centraal behoren te staan zijn: Welke intentie moet de nieuwe IT met zich mee dragen en hoe kan worden bewerkstelligd dat gebruikers overeenkomstig die intentie handelen. Het is raadzaam om de intentie van nieuwe IT in een kantooromgeving vanuit gebruikers zelf voort te laten komen.

De intentie van nieuwe IT in kantooromgevingen zou minder gericht moeten zijn op het verkrijgen van controle op het primaire proces, maar meer op het faciliteren en ondersteunen van gebruikers ten behoeve van hun werk. Gebruikers laten zich moeilijk 'kooien' door een stuk techniek.

Gebruikers moeten niet worden genegeerd in IT projecten, maar als de verantwoordelijken voor het laten ontstaan van de intentie van de IT worden beschouwd. Daarbij behoren zij dan ook de benodigde bevoegdheden in het IT project te krijgen.

De organisatorische inbedding van nieuwe IT is een aspect dat nadrukkelijk aandacht vereist. In IT projecten zou men er vanuit moeten gaan dat ontwikkeling van nieuwe IT en de implementatie ervan onlosmakelijk verbonden zijn met de organisationele context waarin de IT wordt gebruikt. Nog sterker, het gebruik van nieuwe IT brengt zonder meer onverwachte organisatorische veranderingen teweeg. Hiervoor is niet te plannen, enkel kan men zich voorbereiden op het verwachten van het onverwachte.

Implementatie van nieuwe IT eindigt niet na de technische installatie. Het begint dan pas! IT gebruik is een proces van toe-ëigening, dit behoeft een voortdurende facilitering van de gebruiker. Het gaat er immers om dat de gebruiker de IT toe-ëigent overeenkomstig de intentie.

Tot slot, verbetering van de effectiviteit van de werkprocessen is geen zaak van het implementeren van nieuwe IT, maar een zaak van beinvloeding van menselijk gedrag. 


\section{Appendix 1}

\section{Questionnaire}

The questionnaire consisted mostly of propositions. Respondents were asked to express to what extent they agreed with a proposition. This could be done by rating a proposition using a five-point response format:

The questionnaire is translated from Dutch; between the brackets the name of the system was placed)
1 Strongly disagree
2 Disagree
3 Partly agree, partly disagree
4 Agree
5 Strongly agree
9 Not relevant

If a respondent considered that none of the alternatives matched their opinion, they were asked to choose the closest alternative. Only if propositions were really not relevant to a respondent's situation, were then asked to choose the alternative response "9", which meant: not relevant to my situation. 


\section{Personal data}

The following questions concern a number of general topics such as age, education etc. Please, place a circle around the most appropriate answer, place a cross in a box, or insert an answer on the dotted line.

A. Are you male or female? (please, place a cross in one of the boxes)

$\square$ male female

B. What is your age?

C. How long have you been working for this company?

D. What is your current job?

E. How long have you been working in this department?

F. What type of education did you follow and graduate from?

1 Lager Onderwijs/Lager Beroeps Onderwijs

2 MAVO, MULO, ULO

3 HAVO, HBS

4 VWO, Atheneum, Gymnasium (zoals LEAO, VBO)

5 Middelbaar Beroepsonderwijs (MTS/MEAO)

6 Hoger Beroepsonderwijs (HTS/HEAO)

7 Universiteit, $\mathrm{TH}$

\section{Use of '[name of office}

\section{technology (OT)]"}

1. I use the [OT]. (place a circle around the relevant answer)

2. To what extent do you use [OT]?

b. How long have you been working with [OT]? 
1. Strongly disagree

2. Disagree

3. Partly agree, partly disagree

4. Agree

5. Strongly agree

9. Not relevant

(Items 3 to 7 concern the scale "clarity of the spirit")

3. The goals of $[\mathrm{OT}]$ are clear.

4. The "thought behind" [OT] is quite clear to me. $\quad \begin{array}{llllllll}1 & 2 & 3 & 4 & 5 & 9\end{array}$

5. I know where effective use of [OT] should lead. $\quad \begin{array}{lllllll}1 & 2 & 3 & 4 & 5 & 9\end{array}$

6. I understand what designers of [OT] aimed for. $\quad \begin{array}{llllllll}1 & 2 & 3 & 4 & 5 & 9\end{array}$

7. I know in what way according to [OT] experts, for example system managers, the [OT] is used optimally.

(Items 8 to 12 concern the scale "perceived usefulness".

Items 13 to 17 concern the scale "perceived ease of use".)

Using [OT]:

8. ....... think is a good idea.

9. .......contributes to my effectiveness.

10. ...... is not my preference, because there are better ways than using [OT].

11. ......makes my work easier.

12. ......is useful for my work.

13. It is easy to learn to work with [OT].

14. Most functionalities of [OT] are easy.

15. The screens of [OT] are easy to understand.

16. I find [OT] flexible in use.

17. I think [OT] is easy to use.

$\begin{array}{llllll}1 & 2 & 3 & 4 & 5 & 9 \\ 1 & 2 & 3 & 4 & 5 & 9 \\ 1 & 2 & 3 & 4 & 5 & 9 \\ 1 & 2 & 3 & 4 & 5 & 9 \\ 1 & 2 & 3 & 4 & 5 & 9 \\ 1 & 2 & 3 & 4 & 5 & 9 \\ 1 & 2 & 3 & 4 & 5 & 9 \\ 1 & 2 & 3 & 4 & 5 & 9 \\ 1 & 2 & 3 & 4 & 5 & 9 \\ 1 & 2 & 3 & 4 & 5 & 9\end{array}$

In the following propositions sometimes the term "[OT] experts" is used. This refers to people who are very acquainted with the [OT], 
such as system managers within your organization. Sometimes

propositions are about how [OT] should be used. In these cases, start from what you believe about how [OT] should be used, for instance as a result of what you heared in information meetings, training sessions, or what you read in manuals.

1. Strongly disagree

2. Disagree

3. Partly agree, partly disagree

4. Agree

5. Strongly agree

9. Not relevant

(Items 18 to 25 concern the scale "faithfulness of appropriation")

18. I use [OT] in accordance with what manuals and/or documentation state it is intented.

19. "[OT] experts" will not agree with my way of using [OT].

$\begin{array}{lllll}1 & 2 & 3 & 4 & 5\end{array}$

20. I probably use [OT] in ways which are new, in comparison with the initial goals of [OT].

21. With certain functionalities of [OT] I probably work in an unusual way.

22. I use [OT] differently from the initial purposes.

23. "[OT] experts" will not consider the way in which I use [OT] as the most appropriate in order to use the system to its maximum.

24. I do not succeed in using [OT] as it is should be used.

25. I do not use [OT] in the optimum way.

The following propositions are about the way [OT] is used.

(Items 26, 27, 28, 30, 31 concern the scale "task oriented use", items 29, 32, 33, 34 concern the scale "explorative use".) 
26. In my work I use the possibilities of [OT] which are relevant to my work.

27. Tasks that can carry out with [OT], I really use [OT] for.

1. Strongly disagree

2. Disagree

3. Partly agree, partly disagree

4. Agree

5. Strongly agree

9. Not relevant

28. I use [OT] much in my daily

work.

$\begin{array}{llllll}1 & 2 & 3 & 4 & 5 & 9\end{array}$

29. I discuss with my colleagues

about how [OT] works.

$\begin{array}{llllll}1 & 2 & 3 & 4 & 5 & 9\end{array}$

30. When I start to use [OT] I

know in advance for which task

I will use it.

$\begin{array}{llllll}1 & 2 & 3 & 4 & 5 & 9\end{array}$

31. I use [OT] to make progress in

my work.

$\begin{array}{llllll}1 & 2 & 3 & 4 & 5 & 9\end{array}$

32. I use the manual of [OT] regularly.

$\begin{array}{llllll}1 & 2 & 3 & 4 & 5 & 9\end{array}$

33. During my work it takes time to 'discover' [OT].

$\begin{array}{llllll}1 & 2 & 3 & 4 & 5 & 9\end{array}$

34. By "trial and error" I still find

out new aspects of [OT].

$\begin{array}{llllll}1 & 2 & 3 & 4 & 5 & 9\end{array}$

Below you are asked to make statements about the extent to which, in your view, users of [OT] in your organization agree upon how to use [OT].

1. Strongly disagree

2. Disagree

3. Partly agree, partly disagree

4. Agree

5. Strongly agree

9. Not relevant 
(Items 35 to 40 concern the scale "consensus on appropriation")

35. Within the group of users of [OT] there is consensus on how to use [OT].

$\begin{array}{llllll}1 & 2 & 3 & 4 & 5 & 9\end{array}$

36. I use [OT] in a fairly identical way to my colleague-users.

$\begin{array}{llllll}1 & 2 & 3 & 4 & 5 & 9\end{array}$

37. Within the group of users there are still considerable misunderstandings about [OT].

$\begin{array}{llllll}1 & 2 & 3 & 4 & 5 & 9\end{array}$

38. There is no difference in opinion within the group of users of [OT] about what you can do with it.

39. Within the group of users there is di-

sagreement about how certain functionalities work.

$\begin{array}{llllll}1 & 2 & 3 & 4 & 5 & 9\end{array}$

40. There are (written or tacit) rules about about how to work with [OT].

Below your opinion is asked about for instance the development and the implementation of [OT].

41. I had a say in the development of [OT].

$\begin{array}{llllll}1 & 2 & 3 & 4 & 5 & 9\end{array}$

42. I had a say in the implementation of [OT].

$\begin{array}{llllll}1 & 2 & 3 & 4 & 5 & 9\end{array}$

Please note! In the following part the response alternatives are as follows:

1. Strongly dissatisfied

2. Dissatisfied

3. Partly satisfied, partly dissatisfied

4. Satisfied

5. Strongly dissatisfied

9. Not relevant

To what extent are you satisfied with:

(Items 43, 45, 46, 48 concern the scale "satis-

faction with implementation process". Item 49

concerns the scale "satisfaction with reasons 
for implementing [OT]". Item 50 concerns the

scale "satisfaction with organizational support".)

43. The development process of [OT].

$\begin{array}{llllll}1 & 2 & 3 & 4 & 5 & 9\end{array}$

44. The influence you had in the development process of [OT].

45. The way [OT] was implemented.

46. The duration of the implementation of [OT].

47. The influence you had on the implementation of [OT].

48. The information/training about [OT].

49. The reasons why [OT] was implemented.

50. The support from the organization while using [OT].

$\begin{array}{llllll}1 & 2 & 3 & 4 & 5 & 9 \\ 1 & 2 & 3 & 4 & 5 & 9 \\ 1 & 2 & 3 & 4 & 5 & 9\end{array}$

$\begin{array}{llllll}1 & 2 & 3 & 4 & 5 & 9\end{array}$

$\begin{array}{llllll}1 & 2 & 3 & 4 & 5 & 9\end{array}$

$\begin{array}{llllll}1 & 2 & 3 & 4 & 5 & 9\end{array}$

$\begin{array}{llllll}1 & 2 & 3 & 4 & 5 & 9\end{array}$

From here on the response alternatives revert to those shown here:

1. Strongly disagree

2. Disagree

3. Partly agree, partly disagree

4. Agree

5. Strongly disagree

9. Not relevant

\section{Your work situation}

The following propositions are about aspects of your own work situation.

(Items 51 to 54 concern the scale "internal organizational change along with the office technology implementation".)

With the implementation of [OT]:

51 .......changes have occur-

red in my tasks.

52 .....changes occurred in

my physical work environ-

ment..

$\begin{array}{lllll}1 & 2 & 3 & 4 & 5\end{array}$

9 
53 ..changes occurred in

the composition of the employ-

ees in my department/unit.

$\begin{array}{lllll}1 & 2 & 3 & 4 & 5\end{array}$

9

54 .....the performance crite-

ria regarding my job changed.

$\begin{array}{lllll}1 & 2 & 3 & 4 & 5\end{array}$

9

The following propositions concern the way work processes which can be supported by the group of users of [OT] are going. It is, however, not necessary that you really use [OT] for these, but that you can use other means.

(Items 55 to 58 concern the scale "work process effectiveness".)

Within the group of users of [OT]:

55 ......work processes are progressing in an effective way.

$\begin{array}{llllll}1 & 2 & 3 & 4 & 5 & 9\end{array}$

56 .....work processes are progressing rapidly.

$\begin{array}{llllll}1 & 2 & 3 & 4 & 5 & 9\end{array}$

57 .....the level of mistakes is low.

$\begin{array}{lllll}1 & 2 & 3 & 4 & 5\end{array}$

9

58 .....the amount of work that is being carried out is high.

$\begin{array}{lllll}1 & 2 & 3 & 4 & 5\end{array}$

9

(Items 59 to 61 concern the scale "work autonomy".)

Finally, a few propositions about your work.

59 I can determine the amount of work I want to do myself.

$\begin{array}{lllll}1 & 2 & 3 & 4 & 5\end{array}$

60 I can determine the sequence of tasks myself.

61 I can determine how fast I carry out my work.

Thank you for your cooperation! 


\section{Combined dataset}

Descriptive Statistics

\begin{tabular}{|c|c|c|c|c|c|}
\hline & $\bar{N}$ & Minimum & Maximum & Mean & Std. Deviation \\
\hline the extent to which & & & & & \\
\hline $\begin{array}{l}\text { respondents know the } \\
\text { original design intent and } \\
\text { goals }\end{array}$ & 112 & 1.00 & 5.00 & 3.7942 & .6620 \\
\hline $\begin{array}{l}\text { the extent to which a } \\
\text { respondent uses the DIS } \\
\text { system }\end{array}$ & 113 & 1.00 & 5.00 & 4.1416 & 1.0595 \\
\hline $\begin{array}{l}\text { the extent to which } \\
\text { respondents use system }\end{array}$ & & & & & \\
\hline $\begin{array}{l}\text { structures consistent with } \\
\text { the original design intent } \\
\text { of system experts }\end{array}$ & 113 & 1.33 & 5.00 & 3.6685 & .5596 \\
\hline $\begin{array}{l}\text { the extent the system is } \\
\text { perceived useful }\end{array}$ & 113 & 1.80 & 5.00 & 3.7870 & .7023 \\
\hline $\begin{array}{l}\text { the extent to which the } \\
\text { system is perceived easy } \\
\text { in use }\end{array}$ & 113 & 1.00 & 5.00 & 3.6376 & .7083 \\
\hline $\begin{array}{l}\text { the extent to which the } \\
\text { respondent use the } \\
\text { system taskoriented }\end{array}$ & 113 & 2.00 & 5.00 & 3.9521 & .5970 \\
\hline $\begin{array}{l}\text { the extent to which } \\
\text { respondents use the } \\
\text { system in explorative ways }\end{array}$ & 113 & 1.00 & 4.75 & 2.5590 & .8690 \\
\hline the extent to which & & & & & \\
\hline $\begin{array}{l}\text { respondents agree on how } \\
\text { to use the system }\end{array}$ & 110 & 2.00 & 4.83 & 3.3523 & .5582 \\
\hline $\begin{array}{l}\text { the extent to which the } \\
\text { respondent had a say in } \\
\text { implementing ..... }\end{array}$ & 92 & 1.00 & 5.00 & 2.0652 & 1.1271 \\
\hline $\begin{array}{l}\text { the extent to which the } \\
\text { respondent had a say in } \\
\text { developing ..... }\end{array}$ & 90 & 1.00 & 5.00 & 2.2444 & 1.2570 \\
\hline $\begin{array}{l}\text { de mate waarin gebruikers } \\
\text { tevreden zijn met het } \\
\text { implementatieproces }\end{array}$ & 100 & 1.00 & 5.00 & 2.9158 & .8069 \\
\hline $\begin{array}{l}\text { the extent to which the } \\
\text { implementation was } \\
\text { combined with changes in } \\
\text { the work environment }\end{array}$ & 96 & 1.00 & 5.00 & 2.5929 & .8831 \\
\hline $\begin{array}{l}\text { the extent to which the } \\
\text { system contributes to the } \\
\text { effectiveness of the work } \\
\text { processes }\end{array}$ & 110 & 1.00 & 4.50 & 3.1295 & .6585 \\
\hline $\begin{array}{l}\text { the extent to which the } \\
\text { respondent experiences } \\
\text { autonomy in his or her job }\end{array}$ & 112 & 1.00 & 5.00 & 3.2202 & .9685 \\
\hline $\begin{array}{l}\text { in welke mate tevreden } \\
\text { over ondersteuning bij } \\
\text { problemen }\end{array}$ & 106 & 1.00 & 5.00 & 3.3585 & .9680 \\
\hline $\begin{array}{l}\text { in welke mate tevreden } \\
\text { over redenen voor } \\
\text { invoering }\end{array}$ & 96 & 1.00 & 5.00 & 3.6771 & .7469 \\
\hline Valid N (listwise) & 68 & & & & \\
\hline
\end{tabular}


Descriptive Statistics ${ }^{a}$

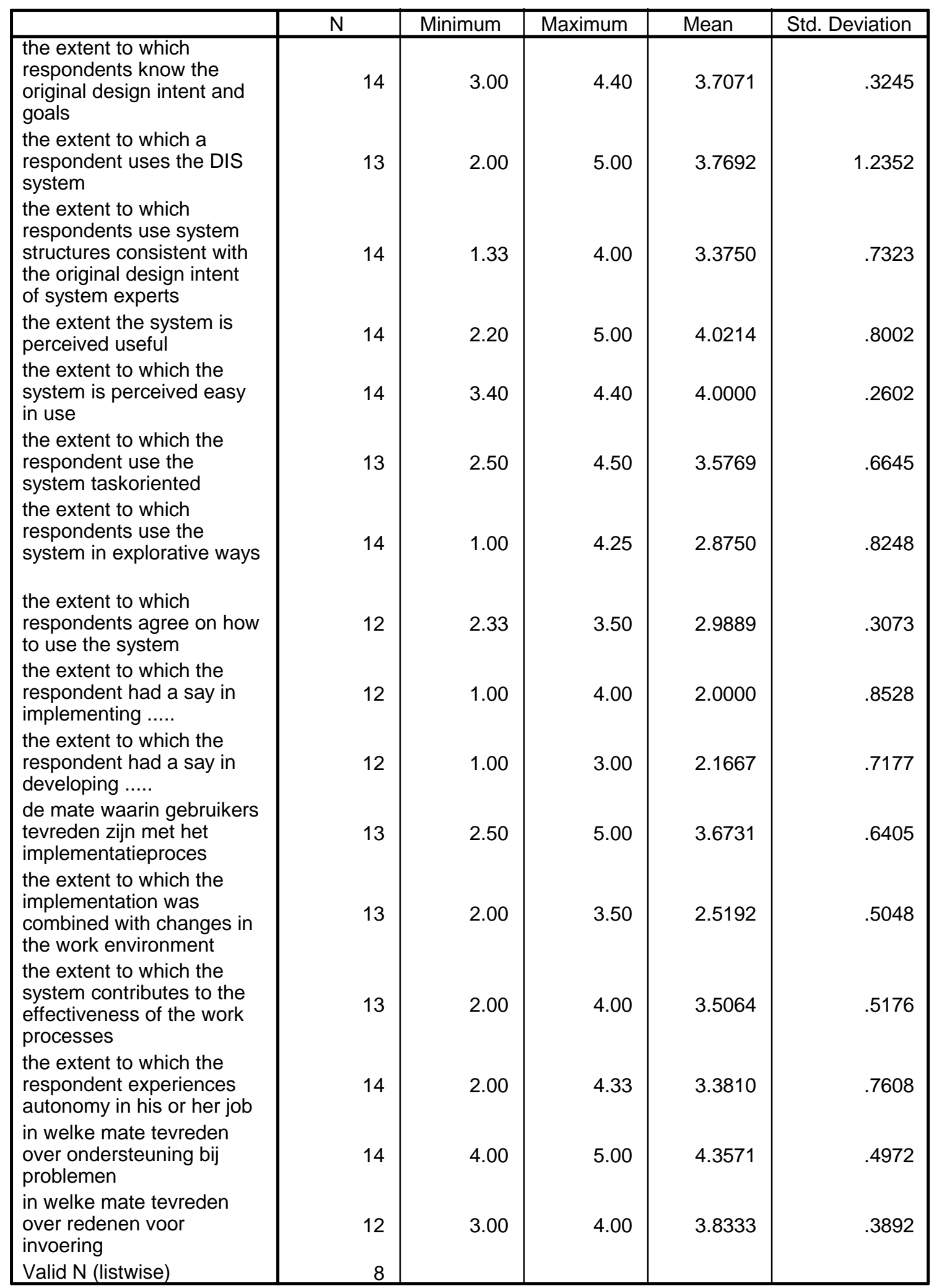

a. organisation in which respondent is employed = faculty computer science 
Descriptive Statistics ${ }^{a}$

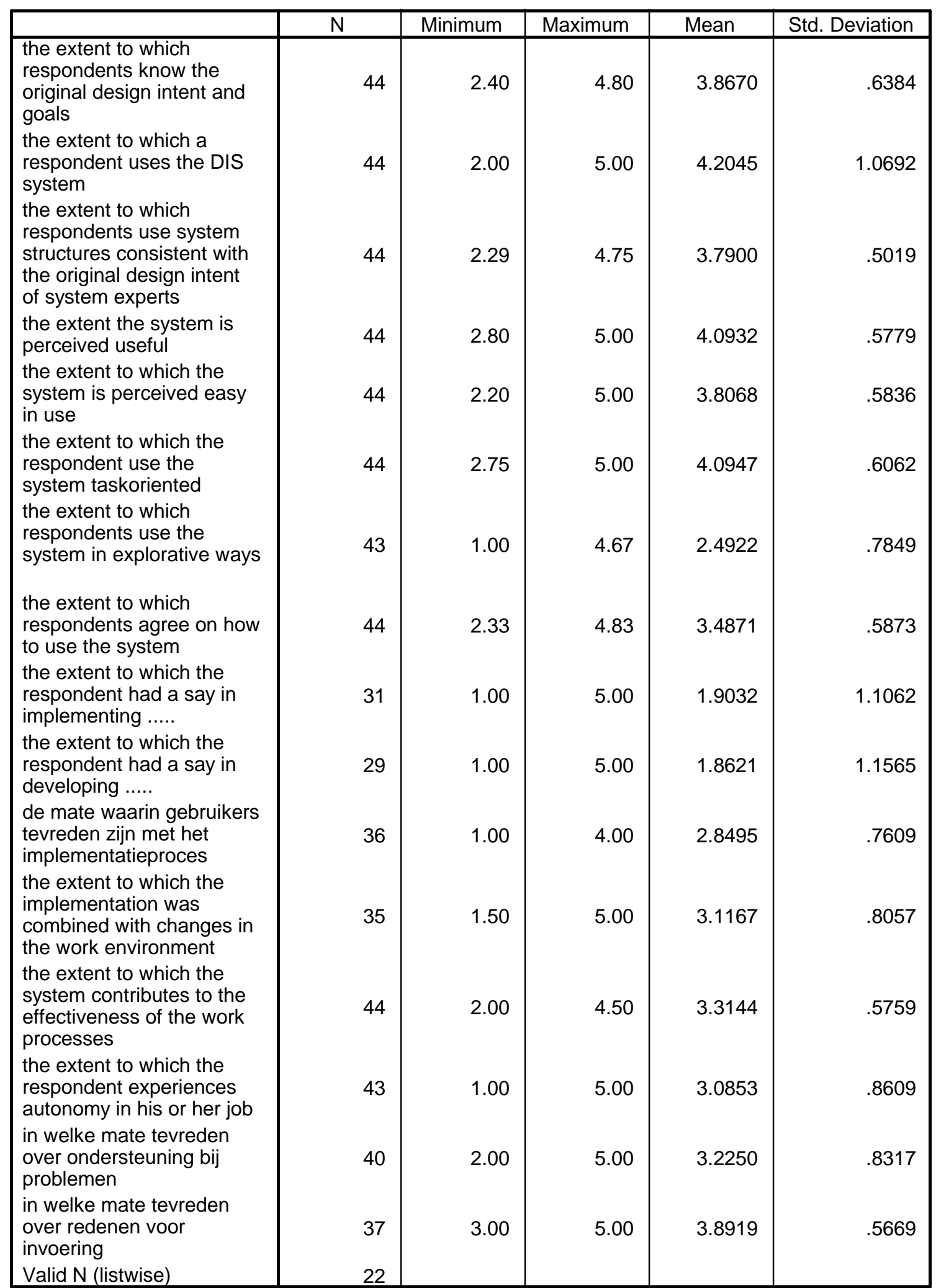

a. organisation in which respondent is employed = snsreaal 
Descriptive Statistics ${ }^{a}$

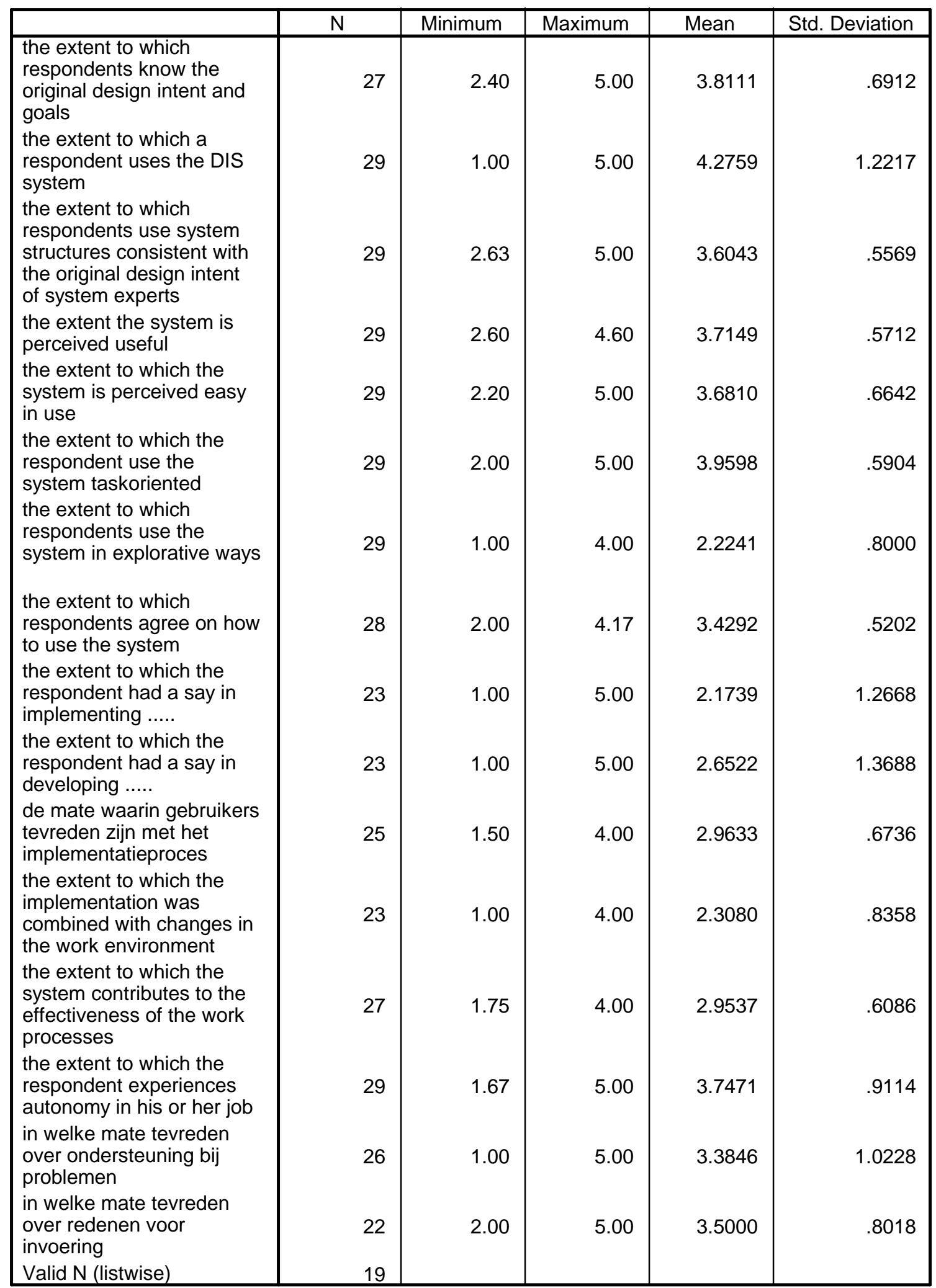

a. organisation in which respondent is employed = avero 
Descriptive Statistics ${ }^{a}$

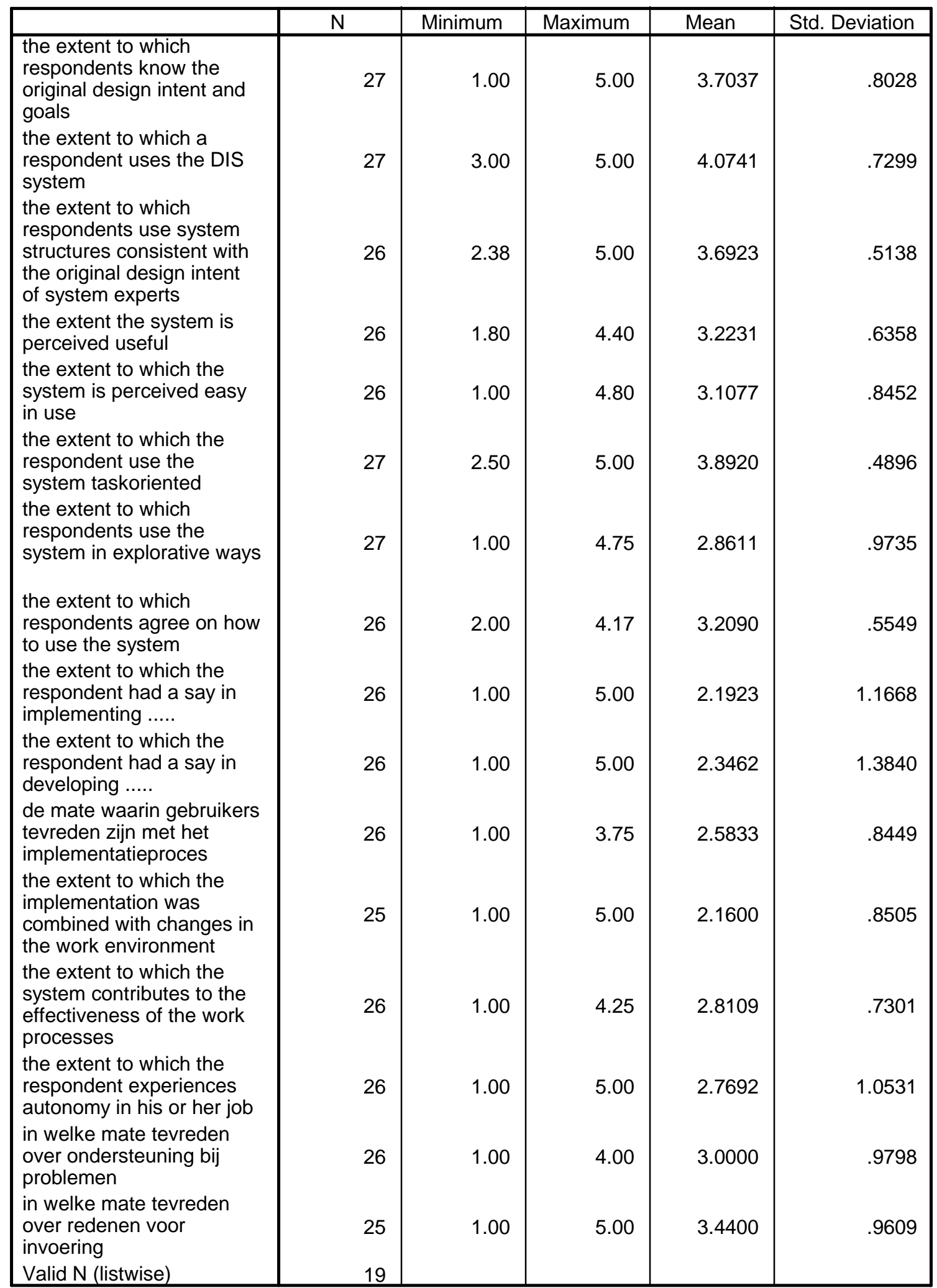

a. organisation in which respondent is employed = abnamro 